\title{
Derechos humanos y presupuestos públicos
}

Juan Manuel ORTEGA MALDONADO Roberto MARTINEZ REGINO Coordinadores

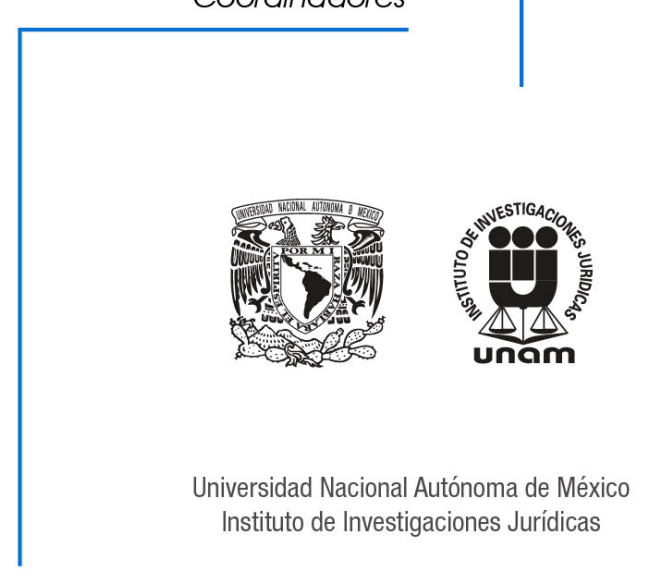


DERECHOS HUMANOS Y PRESUPUESTOS PÚBLICOS 


\section{INSTITUTO DE INVESTIGACIONES JURÍDICAS}

SERIE DOGTRINA JURÍdicA, Núm. 836

\section{COORDINAGIÓN EDITORIAL}

Lic. Raúl Márquez Romero

Secretario Técnico

Lic. Wendy Vanesa Rocha Cacho

Jefa del Departamento de Publicaciones

Iván Escoto Mora

Cuidado de la edición

Javier Mendoza Villegas

Formación en computadora

Mauricio Ortega Garduño

Elaboración de portada 


\title{
DERECHOS HUMANOS Y PRESUPUESTOS PÚBLICOS
}

\author{
Juan Manuel Ortega Maldonado \\ ROBERTO MARTINEZ REGINO
}

Coordinadores
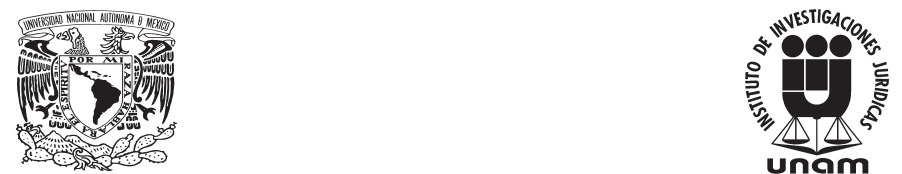

UNIVERSIDAD NAGIONAL AUTÓNOMA DE MÉXICO INSTITUTO DE INVESTIGACIONES JURÍDICAS

MÉXICO, 2018 
Primera edición: 22 de agosto de 2018

DR @ 2018. Universidad Nacional Autónoma de México

INSTITUTO DE INVESTIGACIONES JURÍDICAS

Circuito Maestro Mario de la Cueva s/n Ciudad de la Investigación en Humanidades Ciudad Universitaria, 04510 Ciudad de México

Impreso y hecho en México

ISBN 978-607-30-0744-3 


\section{CONTENIDO}

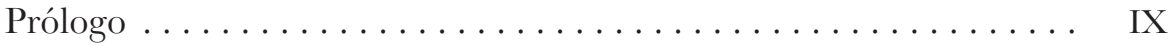

Juan Manuel OrTEga MALDONADO

Repensar el derecho presupuestario en el siglo XXI......... 1 Horacio CORTI

La Constitución financiera mexicana y los derechos humanos . . . . 49 Juan Manuel ORTEGa MALDONADO

Los derechos humanos en el ciclo presupuestario ........... 61 Óscar NAvA Escudero

Los precedentes de los jueces en la discusión sobre el presupuesto público y derechos humanos en México . . . . . . . . . . . . . . Roberto MARTINEZ REGINO

Tratamiento jurisprudencial de los presupuestos públicos y derechos humanos en Colombia . . . . . . . . . . . . . . . . . . . . . 11 Lizeth Juliana GARCíA ATRA

"La colisión de los presupuestos de egresos con el contexto internacional"................................. 131

Beatriz MONRROY LÓPEZ

Derecho comparado sobre presupuestos participativos: México-España 151 Carolina Aguilar Ramos 
Este libro forma parte del acervo de la Biblioteca Jurídica Virtual del Instituto de Investigaciones Jurídicas de la UNAM

\section{PRÓLOGO}

Para estar en posibilidad de cumplir con las obligaciones en materia de derechos humanos a los que el Estado mexicano se ha comprometido, es indispensable contar tanto con políticas públicas orientadas a promover, respetar, proteger y garantizar los derechos humanos de todas las personas, como con los recursos económicos suficientes para alcanzar ese propósito.

En el ámbito nacional ya contamos con experiencias que muestran alguna ruta clara. En ese sentido puede analizarse el Programa de Derechos Humanos de la Ciudad de México. ${ }^{1}$ Asimismo, no pueden dejarse de lado los interesantes estudios realizados por Fundar, ${ }^{2}$ Gesoc, ${ }^{3}$ por la Oficina del Alto Comisionado de las Naciones Unidas en México ${ }^{4}$ o los realizados por la propia Secretaría de Gobernación del Gobierno Federal. ${ }^{5}$

Sin embargo, es en el derecho internacional de los derechos humanos donde hallaremos los instrumentos para abrevar de mejor manera, pues ahí se proveen las definiciones de cada derecho y que proporciona los lineamientos para generar herramientas de gestión y administración pública con perspectiva de derechos humanos. En efecto, es aquí donde encontraremos las directrices básicas para que los Estados incorporen a sus políticas públicas, marcos jurídicos y presupuestos públicos, este enfoque de derechos humanos.

Específicamente, el cumplimiento de los derechos humanos a través de las políticas y presupuestos políticos se declara en forma expresa en el Pacto Internacional de Derechos Económicos, Sociales y Culturales, en su artículo 2.1., que textualmente indica:

1. Cada uno de los Estados Partes en el presente Pacto se compromete a adoptar medidas, tanto por separado como mediante la asistencia y la coope-

\footnotetext{
1 Disponible en: http://wrere.pdh.cdmx.gob.mx/index.php/conoce-el-programa.

2 Fundar, Centro de Análisis e Investigación, A. C.

3 Gestión Social y Cooperación, A. C.

4 Véase, en ese sentido, el importante estudio disponible en: $h t t p: / /$ wrwr.hchrorg.mx/images /doc_pub/L280211PPDH.pdf.

5 Manualy protocolo para la elaboración de politicas públicas de derechos humanos conforme a los nuevos principios constitucionales, disponible en: http://incan-mexico.org/incan/docs/POT/manual-1.pdf.
} 
Este libro forma parte del acervo de la Biblioteca Jurídica Virtual del Instituto de Investigaciones Jurídicas de la UNAM

ración internacionales, especialmente económicas y técnicas, hasta el máximo de los recursos de que disponga, para lograr progresivamente, por todos los medios apropiados, inclusive en particular la adopción de medidas legislativas, la plena efectividad de los derechos aquí reconocidos.

Estas obligaciones, a más de complementarse, sirven de soporte para hacer realidad los "pisos mínimos de bienestar". Para garantizar ese mínimo y niveles superiores de bienestar, es necesario incorporar las perspectivas de derechos humanos en cada una de las etapas de los ciclos del presupuesto y de las políticas públicas, concretamente en los planes de desarrollo, los planes sectoriales, programas específicos, y sus reglas de operación.

Del mismo modo debe procederse para incluir la perspectiva de derechos humanos en las etapas de los presupuestos públicos: desde el diseño de las políticas recaudadoras, hasta la formulación, discusión-aprobación, ejecución y evaluación-fiscalización de los recursos públicos. Un punto importante es que el ajustar los presupuestos públicos con la perspectiva de derechos humanos hace que la administración y gestión de los recursos públicos se legitime socialmente.

Dicho de otra forma, el principio de la utilización del máximo de los recursos disponibles del Estado mexicano, implica garantizar que se ingresen todos los recursos fiscales posibles, que no se presenten subejercicios fiscales, que no existan desviaciones de recursos y, sobre todo, que se establezcan criterios claros para la priorización de recursos, asegurando que se gaste lo suficiente para el cumplimiento de derechos.

Esto a su vez requiere dotar de contenido de derechos a las características del gasto público señaladas en el artículo 134 de la Constitución: eficiencia, eficacia, economía, transparencia y honradez. Estas características no pueden entenderse sólo en términos de austeridad y uso eficiente de los recursos, sino que el uso de los recursos públicos debe servir para materializar los elementos de los derechos humanos, tales como calidad, accesibilidad, disponibilidad y aceptabilidad de los servicios y los bienes que provee el gobierno para cumplir con sus obligaciones en materia de derechos humanos.

Teniendo como referencia este marco, en noviembre de 2016 nos reunimos un cúmulo de profesores, bajo el cobijo de la Facultad de Derecho de la Universidad Autónoma del Estado de Morelos, para discutir sobre temas relacionados: presupuestos públicos y derechos humanos. El objetivo era escuchar de viva voz las experiencias de quienes han acudido ante los tribunales para exigir el cumplimiento de las promesas económicas derivadas de los derechos humanos consagradas en la Constitución y en otros instrumentos internacionales. Esta obra es fruto de esas reflexiones. 
Este libro forma parte del acervo de la Biblioteca Jurídica Virtual del Instituto de Investigaciones Jurídicas de la UNAM

La buena pluma de mi buen amigo, el profesor Horacio Corti, es quien abre esta serie de discusiones con un interesantísimo estudio titulado: "Repensar el derecho presupuestario en el siglo XXI". Debo decir que el profesor Corti es actualmente el defensor general del Ministerio Público de la Ciudad Autónoma de Buenos Aires y una de sus principales actividades cotidianas es, precisamente, asegurar que los derechos humanos de los ciudadanos de esa ciudad capital en Argentina cuenten con los recursos suficientes para satisfacer mínimamente sus derechos fundamentales.

La aportación del profesor Corti sin duda constituirá un parteaguas en el estudio del derecho presupuestario en nuestro país, no sólo por lo que dice aquí, sino por lo que ha venido afirmando desde hace varios años con trabajos en materia presupuestaria. A aquellos trabajos ${ }^{6}$ ha de sumarse ahora éste. No quiero ceder a la tentación de resumir lo que mi colega sostiene en este apartado; prefiero que sea usted amable lector quien dé cuenta de las aportaciones del también profesor en la Universidad de Buenos Aires, y al final, seguro estoy que no sólo quedará convencido, como quedé yo, sino que advertirá que no hay perdida en ninguna de sus líneas. Lo invito a disfrutar de esta parte del libro.

Seguidamente a la obra del profesor Corti, me he permito expresar algunas ideas sobre "La Constitución financiera mexicana y los derechos humanos". De unos años acá, estoy persuadido que nuestra carta magna ha modificado su eje de rotación. Los derechos humanos son su preocupación principal y para hacerlos realidad el Estado requiere recursos económicos pues esos derechos no pueden serlo sin esos recursos. Como la base de los ingresos y presupuestos públicos radica en la Constitución, debe hoy hablarse de una Constitución financiera, esto es, una Constitución cuya totalidad de instituciones y figuras están en función al objetivo central de la misma, la protección de los derechos humanos.

En la tercera parte aparece un extraordinario trabajo de investigación a cargo de un añejo amigo mío, el doctor Óscar Nava Escudero. "Óscar" - como cariñosamente le digo - y yo, compartimos las aulas en la Universidad Complutense de Madrid, España, entre 1999 y 2002, mientras ambos realizábamos nuestros estudios de doctorado. Producto de esa amistad fue que decidimos organizar el Congreso del que surgió esta obra. El doctor Nava nos ofrece una seria y profunda reflexión: "Los derechos humanos en el ciclo presupuestario". Seguro que después de leerla quedará en claro por qué resulta necesario insertar la perspectiva de derechos humanos en todas las etapas del ciclo presupuestario, como lo afirmamos líneas arriba. Lo invito a debatir con el autor sus ideas.

6 Corti, Horacio, Derecho constitucional presupuestario, Argentina, Abeledo-Perrot, 2011. 
Este libro forma parte del acervo de la Biblioteca Jurídica Virtual del Instituto de Investigaciones Jurídicas de la UNAM

La obra se nutre también de aportaciones de jóvenes investigadores, pero no por ello de menores méritos académicos. Tal es el caso del profesor Roberto Martinez Regino, quien recién a finales del año pasado se graduó de doctor en derecho con una tesis relacionada con el tema y de la cual extrajo una parte para compartirla con nosotros que tituló: "Los precedentes de los jueces en la discusión sobre el presupuesto público y derechos humanos en México". El nuevo doctor nos ofrece una serie de casos en los cuales los jueces mexicanos han encarado la defensa de los derechos humanos a través de la incidencia sobre los presupuestos públicos, tema por demás controvertible todavía en México y que causa encendidas polémicas.

Otro estudio importante es el que la maestra Beatriz Monrroy López nos presenta: "La colisión de los presupuestos de egresos con el contexto internacional". Afirma la profesora de la Universidad Autónoma del Estado de Morelos, que el presupuesto público en México no es ni por mucho, un acto aislado y soberano del Congreso y gobierno mexicano, en el sentido literal de la palabra, sino el producto de compromisos internacionales.

En este libro también escuchamos la voz de la maestra en derecho Lizeth Juliana García Atra, quien nos ofrece un interesante estudio sobre los casos resueltos por los tribunales colombianos en materia de presupuestos públicos y derechos humanos. Lo que yo advertí de ese estudio es lo familiar que ya resultan estos asuntos en aquel país. Sin duda debemos abrevar de esas experiencias. La maestra García Atra titula su capítulo como: "Tratamiento jurisprudencial de los presupuestos públicos y derechos humanos en Colombia".

La obra se cierra con una aportación básica sobre este binomio: "Derecho comparado sobre presupuestos participativos: México-España”. Estudio realizado por la maestra Carolina Aguilar Ramos, que también constituyó parte fundamental de su tesis de maestría, con alguna estancia de investigación en España. Este trabajo nos muestra un futuro promisorio de los presupuestos públicos y su engarce con un derecho fundamental, la participación ciudadana.

No quiero dejar pasar la oportunidad para agradecer en esta parte a mis alumnos de maestría y doctorado en la Universidad Autónoma del Estado de Morelos por su invaluable apoyo en la realización del Congreso celebrado en noviembre de 2016, a mi colega y amigo el doctor Roberto Martinez Regino por su apoyo en la revisión y coordinación del trabajo y por supuesto, al Instituto de Investigaciones Jurídicas de la UNAM, por el decidido apoyo en la realización de esta obra. 
Este libro forma parte del acervo de la Biblioteca Jurídica Virtual del Instituto de Investigaciones Jurídicas de la UNAM

\title{
REPENSAR EL DEREGHO PRESUPUESTARIO EN EL SIGLO XXI
}

\author{
Horacio CORTI*
}

\begin{abstract}
SUMARIO: I. Las finanzas públicas desde la lógica constitucional. La Constitución financiera. II. Sentido y finalidad de la actividad financiera pública. III. El concepto de necesidad pública como obstáculo epistemológico. IV. La unidad constitucional del derecho financiero. Principios y conceptos comunes. V. La ley de presupuesto como eje de la Constitución financiera. VI. La reconfiguración de toda la lógica constitucional. VII. La apertura del derecho financiero. VIII. Ley de presupuesto y derechos humanos. IX. El derecho internacional de los derechos humanos. X. Dos modelos de argumentación judicial. XI. La experiencia comparada entre ambos paradigmas de argumentación. XII. Sistematización de la problemática presupuestaria en los procesos judiciales.
\end{abstract}

Este maravilloso Congreso Internacional sobre presupuestos públicos y derechos humanos que estamos protagonizando en la Universidad de Morelos, Cuernavaca, organizado por grandes amigos mexicanos, es una buena oportunidad para sintetizar algunas investigaciones iniciadas hace ya más de dos décadas y para señalar a su vez algunos nuevos caminos de desarrollo. ${ }^{1}$

Señalaba Álvaro Rodríguez Bereijo en su monografía sobre el derecho presupuestario de la década del setenta del siglo pasado: "El derecho presupuestario que corresponde a la fase histórica del Estado social de Dere-

* Doctor en derecho por la Facultad de Derecho y Ciencias Sociales de la Universidad de Buenos Aires; defensor general del Ministerio Público de la Ciudad Autónoma de Buenos Aires. Correo electrónico:hcorti@jusbaires.gov.ar.

1 Los primeros trabajos iniciados en 1994 dieron lugar a un primer texto, Derecho financiero, Buenos Aires, Abeledo Perrot, 1997. Una visión sistemática está expuesta en Derecho constitucional presupuestario, Buenos Aires, Abeledo-Perrot, 2007. Luego editamos una obra colectiva y comparatista en dos volúmenes: El derecho constitucional presupuestario en el derecho comparado, Buenos Aires, Abeledo-Perrot, 2010 (con la colaboración de Mercedes Casás y Victoria Álvarez). Allí incluimos el ensayo "Ley de presupuesto y derechos fundamentales: los fundamentos de un nuevo paradigma jurídico-financiero", pp. 637 y ss. 
Este libro forma parte del acervo de la Biblioteca Jurídica Virtual del Instituto de Investigaciones Jurídicas de la UNAM

cho y las nuevas orientaciones de la ciencia financiera, superación del viejo derecho presupuestario liberal burgués del siglo XIX, cuyos ecos todavía perduran, está en gran medida por hacer". ${ }^{2}$

El juicio de Rodríguez Bereijo conserva su actualidad. El presupuesto fue en lo esencial pensado en el marco del Estado legal de derecho. Aún es una tarea pendiente construir un derecho presupuestario acorde a las características del Estado social y democrático de derecho. Muchas son las modificaciones que este Estado implica. De todas ellas, el punto decisivo consiste en la profundización del sistema de derechos fundamentales.

Es preciso repensar el derecho presupuestario desde su raíz misma, asimilando una rica tradición jurídica (que se encuentra sintetizada simbólicamente en el debate sobre la naturaleza de la ley de presupuesto y que tiene un hito doctrinario en el ensayo de Paul Laband de 1871) pero reinterpretándola a la luz de la arquitectura del Estado constitucional de derecho contemporáneo.

El paradigma del Estado social y democrático de derecho, que es hoy el trasfondo constitucional común de nuestra cultura jurídica, impone volver a pensar todas las instituciones jurídicas, entre ellas el presupuesto del Estado.

El constitucionalismo europeo de posguerra forjó diversas fórmulas para referirse a peculiaridad del Estado de derecho que se estaba conformando: República democrática basada en el trabajo (Constitución de Italia de 1947, artículo 1o.); Estado federal democrático y social (Ley Fundamental de Alemania de 1949, artículo 20.1.); Estado social y democrático de derecho (Constitución de España de 1978, artículo 1.1.). Otras tantas expresiones han sido utilizadas en el constitucionalismo latinoamericano de las últimas décadas.

Y no se trata de fórmulas sin consecuencias jurídicas, como lo muestra la jurisprudencia del Tribunal Constitucional alemán al considerar derechos sociales incluidos en el concepto de Estado social (véase caso Hartz IV del 9 de febrero de 2010). ${ }^{3}$

Hay tres hechos adicionales que es preciso hoy tener en cuenta para repensar el derecho presupuestario contemporáneo.

Primero, la crisis del Estado de bienestar y las diferentes respuestas generadas ante esa situación, en general tendientes a desmantelar las institu-

2 Rodríguez Bereijo, Álvaro, El presupuesto del Estado. Introducción al derecho presupuestario, Madrid, Tecnos, 1976.

3 Tenorio Sánchez, Pedro, "El Tribunal Constitucional, la cláusula del Estado social, los derechos sociales y el derecho a un mínimo vital digno en la República Federal Alemana”, Estudios de Deusto, Bilbao, vol. 59, núm. 2, junio-diciembre de 2011, pp. 127-167. 
Este libro forma parte del acervo de la Biblioteca Jurídica Virtual del Instituto de Investigaciones Jurídicas de la UNAM

ciones jurídicas que concretizan dicho Estado y que se manifiestan como políticas de reducción del gasto público.

Segundo, la interrelación profunda entre los derechos nacional, comunitario e internacional. El derecho internacional es actualmente muy complejo. Uno de sus elementos centrales es el derecho internacional de los derechos humanos, estructurado en diversos sistemas (universal, regionales), con múltiples órganos (cortes, comités), que generan diferentes tipos de documentos (sentencias, observaciones generales, opiniones consultivas, informes), todo ello en íntima interacción con los derechos nacionales. Junto a ello hay que considerar el proceso comunitario europeo. Y en otro andarivel, de compleja relación con los derechos humanos, el derecho internacional de las inversiones.

Tercero, la aceleración de los diálogos entre diferentes sistemas jurídicos. Los tribunales tienen en cuenta, con diferentes modalidades, las sentencias de los tribunales extranjeros (o es motivo de debate explícito si deben considerarse o no dichas sentencias, como sucede en Estados Unidos). En las reflexiones doctrinarias tiene cada vez más peso el comparatismo. Los órganos internacionales también tienen en cuenta los argumentos de otros órganos (así por ejemplo la Corte Interamericana menciona en sus argumentos lo dicho por el Tribunal Europeo de los Derechos Humanos). Se propugna incluso el comparatismo como método de interpretación (Häberle).

Estos dos últimos puntos son los que resumimos con el término global. No se trata de un proceso histórico que genere un único derecho positivo llamado global, sino de una forma de destacar que el estudio de un problema jurídico hoy no puede hacerse sólo en el contexto de un derecho nacional sino que exige, por el contrario, tener en cuenta tanto la complejidad de las relaciones entre los derechos nacionales, comunitario e internacional, como las comparaciones entre las diferentes experiencias jurídicas nacionales.

En resumen, nuestro objetivo es repensar el presupuesto público a la luz del Estado social y democrático de derecho en el derecho global y en el contexto de la crisis del Estado de bienestar.

\section{LAS FINANZAS PÚBLICAS DESDE LA LÓGICA CONSTITUCIONAL. La CONSTITUCIÓN FINANCIERA}

Conceptualizar el presupuesto del Estado en los términos antes dichos requiere reflexionar sobre la actividad financiera pública (la hacienda o las finanzas públicas, de acuerdo a sus diferentes designaciones) como un todo. 
Este libro forma parte del acervo de la Biblioteca Jurídica Virtual del Instituto de Investigaciones Jurídicas de la UNAM

Es necesario un cambio de paradigma más amplio, que reformule la lógica financiera en su conjunto.

La clave en la materia consiste en enfocar las finanzas públicas como uno de los elementos fundamentales de la Constitución. La propia lógica conceptual constitucional requiere pensar cómo se financian las instituciones que se establecen.

Dicho subsistema de financiamiento se denomina Constitución financiera. Esta expresión surge en Alemania (Finanzverfasung) para referirse a las cláusulas financieras. ${ }^{4}$ Luego se difundió la expresión en otras tradiciones nacionales, así hoy en Italia: Costituzione Finanziaria o en Brasil: Constitução Financeira. ${ }^{5}$ En Francia, paralelamente, se habla de bloque constitucionalidad de las finanzas públicas. La expresión también se ha difundido en España. ${ }^{6}$

Varias distinciones aquí se imponen. Puede hablarse de Constitución financiera en un sentido débil y uno fuerte.

En un sentido débil sólo es un término que designa las disposiciones constitucionales referidas al derecho financiero. Aquí son posibles, a su vez, dos técnicas de composición constitucional. Aquellas disposiciones pueden estar dispersas en el texto o, en cambio, ya encontrarse reunidas en un capítulo específico del texto constitucional.

En un sentido fuerte la Constitución financiera es el pensamiento que una Constitución contiene sobre su propia financiación y que se expresa, claro, en conceptos, principios y reglas jurídicas. Es una visión más profunda que pone de manifiesto una arquitectura jurídico-constitucional financiera.

4 "El término Constitución financiera - Finanzverfassung - abarca el conjunto de preceptos de la Ley fundamental de Bonn en los cuales se establece el reparto de competencias financieras entre los distintos poderes territoriales, así como los principios rectores de las mismas y cuyo contenido se encuentra básicamente en los artículos 104 a 115 . El término Constitución financiera surgió originariamente de la mano de la doctrina alemana en un sentido diverso al actual, ya que se utilizó inicialmente para referirse a la compensación de las desigualdades interterritoriales o Finanzausgleich. El legislador lo emplea por vez primera en la Ley de 23 de diciembre 1955, mediante la cual se operó una importante reforma constitucional en esta materia, y a partir de este momento se empezó a utilizar en el sentido actual. El Tribunal Constitucional alemán ha sido también uno de los principales responsables del asentamiento de esta terminología", García Frías, Ángeles, "La financiación de los Länder", Revista Catalana de Dret Públic, núm. 32, 2006, p. 234. Véase también, Martul-Ortega, Yebra, Perfecto, Constitución financiera española. Veinticinco años, Madrid, Instituto de Estudios Fiscales, 2004, p. 65.

5 Morrone, Andrea, La costituzione finanziaria. La decisione di bilancio dello Stato costituzionale europeo, Torino, Giappichelli Editore, 2015; Taveira Torres, Heleno, "Direito constitucional financiero. Teoría da Constitução Financeira”, Revista dos Tribunais, São Paulo, 2014.

6 Véase el reciente texto de Rodríguez Bereijo, Álvaro, La Constitución fiscal de España, Madrid, Centro de Estudios Políticos y Constitucionales, 2015. 
Este libro forma parte del acervo de la Biblioteca Jurídica Virtual del Instituto de Investigaciones Jurídicas de la UNAM

Aquí también hay dos posibles puntos de vista. Una perspectiva descriptiva, que se limita a constatar si en una Constitución determinada está o no presente la referida Constitución financiera. Y una perspectiva normativa, que se interroga sobre si resulta justificado o legítimo que una Constitución incluya una Constitución financiera.

En cuanto al primer plano cabe constatar que las constituciones modernas habitualmente contienen disposiciones financieras expresas y a partir de ellas es posible reconstruir en cada caso la Constitución financiera. En general los redactores de las constituciones modernas han sido conscientes de la importancia de la financiación y, por ende, han incorporado una multiplicidad de cláusulas sobre la hacienda pública. Su importancia es de tal magnitud que resulta necesario hacer una clasificación racional de esas cláusulas, a fin de sistematizar las diferentes posibilidades de acuerdo a los variados derechos positivos.

Sobre lo segundo resulta evidente que si una Constitución pretende ser real, viviente, efectiva en el mundo empírico de la sociedad, tiene que pensar cómo se financia.

La presencia de una Constitución financiera es consecuencia de la pretensión de efectividad empírica que es inherente a las constituciones.

Ambos puntos de vista se entrelazan. La conciencia de los constituyentes sobre la centralidad de la financiación los ha llevado a incluir en los textos constitucionales disposiciones sobre la hacienda pública.

En la Argentina es notable el ejemplo de Alberdi, cuyo pensamiento tuvo un peso considerable en el proceso constituyente que dio lugar a la Constitución de 1853.

\section{SENTIDO Y FINALIDAD DE LA ACTIVIDAD FINANCIERA PÚBLICA}

Propongo partir de la siguiente idea elemental: cualquier institución constitucional, si pretender ser real y efectiva en la realidad social, requiere de algún grado de financiamiento. Dicho de forma general: si una Constitución pretende realizarse empíricamente en la sociedad tiene que pensar cómo ella se financia.

Esta simple idea hace de la financiación de la Constitución un aspecto central de cualquier proyecto constitucional.

A las dos columnas vertebrales de las constituciones contemporáneas (las declaraciones de derechos y la organización del poder) hay que añadirle una tercera: la relativa a la financiación de esas propias columnas. 
Este libro forma parte del acervo de la Biblioteca Jurídica Virtual del Instituto de Investigaciones Jurídicas de la UNAM

Cómo se financian los derechos y cómo se financia la organización estatal del poder son cuestiones ineludibles. Y por añadidura: cómo se financian los diferentes fines que son considerados relevantes por las constituciones vigentes.

Es decir: fines, órganos y derechos constitucionales requieren de financiación.

Sin embargo, la doctrina constitucional muchas veces no parece darle a esta cuestión el peso que se merece. Un ejemplo notorio: la edición de un reciente manual de derecho constitucional con los expertos hoy más reconocidos que no dedica ningún capítulo a las cuestiones constitucionales financieras. $^{7}$

De acuerdo a nuestro enfoque, la finalidad de las finanzas públicas es de índole constitucional: ser un medio para otorgarle efectividad a las instituciones de la Constitución. Hay un sentido teleológico de la actividad financiera pública.

\section{EL GONGEPTO DE NEGESIDAD PÚBLICA GOMO OBSTÁGULO EPISTEMOLÓGICO}

Esto implica, en otro frente de disputa, controvertir un lugar común de las finanzas públicas, casi universal, según el cual la finalidad de la hacienda pública es la de satisfacer necesidades públicas.

Según desarrollé en varios lugares, el concepto de necesidades públicas es un obstáculo epistemológico para la comprensión constitucional de las finanzas públicas. ${ }^{8}$

\section{LA UNIDAD GONSTITUGIONAL DEL DEREGHO FINANCIERO. PRINCIPIOS Y CONCEPTOS COMUNES}

De aquí se desprende una consecuencia teórica de vasto alcance: la unidad del derecho financiero es de carácter constitucional. No es una razón interna a una rama jurídica. Por el contrario, dicha rama del derecho existe como tal como consecuencia de la lógica misma de la Constitución en cuanto proyecto que pretende realizarse.

7 Rosenfeld, Michel y Sajo, Andras, The Oxford Handbook of Comparative Constitutional Law, Oxford, Oxford University Press, 2013.

8 Remito a Derecho constitucional presupuestario, capítulo I, punto III.1. "La pérdida de relevancia jurídica del concepto de necesidad pública”. 
Este libro forma parte del acervo de la Biblioteca Jurídica Virtual del Instituto de Investigaciones Jurídicas de la UNAM

No se trata sólo de la constitucionalización del derecho, noción de enormes consecuencias que ha profundizado Ricardo Guastini. ${ }^{9}$ La constitucionalización del derecho significa la penetración (la invasión) del derecho constitucional en cada lugar del ordenamiento. No puede pensarse ninguna institución jurídica (desde la familia hasta el acto administrativo) al margen de la Constitución.

Pero aquí estamos ante un fenómeno jurídico de otra envergadura. La hacienda pública es una pieza central de la propia Constitución. Es la lógica conceptual constitucional la que incluye un momento de reflexión financiera.

Y resulta sensato pensar que es esa lógica la que le da unidad al derecho financiero.

\section{La puesta en crisis de la autonomía del derecho tributario}

De lo anterior se sigue que ya no hay lugar teórico para afirmar la autonomía del derecho tributario. Esta autonomía era un elemento de la tradición jurídica latinoamericana, tal como se encontraba plasmada en las primeras jornadas del Instituto Latinoamericano de Derecho Tributario (ILADT) de 1956 en Montevideo. Según sus conclusiones: "1o. El derecho tributario tiene autonomía dentro de la unidad general del derecho por cuanto se rige por principios propios y posee institutos, conceptos y objeto también propios". ${ }^{10}$

Ya no puede sostenerse el particularismo del derecho tributario, basado en principios y conceptos propios.

Hay una unidad conceptual del derecho financiero que tiene razones que no surgen de la propia rama jurídica (o de la propia disciplina doctrinaria) sino del derecho constitucional.

Se continúa, entonces, la tradición jurídica europea y latinoamericana que piensa de forma unitaria el derecho financiero, ahora sobre una base renovada y constitucional. ${ }^{11}$

9 Guastini, Ricardo, "La constitucionalización del ordenamiento jurídico: el caso italiano”, en Carbonell, Miguel (ed.), Neoconstitucionalismo(s), Madrid, Trotta, 2005, p. 49.

10 En las XXV Jornadas celebradas en Cartagena en 2010 se aprobó, en cambio, la ampliación del objeto de estudio del Instituto Latinoamericano del derecho tributario al derecho financiero o de la hacienda pública, véase Plazas Vega, Mauricio, Derecho de la hacienda pública y derecho tributario, 3a. ed., Bogotá, Temis, 2016, p. 110.

11 Esto significa seguir y profundizar las diferentes tradiciones que afirman la unidad y autonomía del derecho financiero. Para Italia, véase Amatucci, Andrea, "Las raíces de la concepción sustancial del derecho financiero público en Nápoles y en la Italia meridional”, 
Este libro forma parte del acervo de la Biblioteca Jurídica Virtual del Instituto de Investigaciones Jurídicas de la UNAM

\section{Principios constitucionales financieros}

De aquí una segunda consecuencia: hay que pensar los principios constitucionales que son comunes a toda la actividad financiera del Estado.

Se abre un significativo campo de investigación: elaborar los principios constitucionales financieros y reelaborar los tradicionales principios constitucionales tributarios bajo una clave renovada.

Hay un conjunto de principios constitucionales comunes. La reserva de ley, claro. ${ }^{12}$ Pero también la igualdad y los principios que, de acuerdo a las diferentes tradiciones jurídicas y constitucionales, regulan de forma sustancial las decisiones políticas: razonabilidad, equidad o proporcionalidad.

También hay conceptos comunes que implican reelaborar los tradicionales conceptos tributarios; así, el de capacidad contributiva, que es (y siempre lo fue, por lo demás) un genuino concepto financiero.

Esta visión pone fin a la tradicional asimetría conceptual entre gastos y recursos, destacada por ejemplo por Julien Valls:

La cuestión de la constitucionalidad material de los gastos públicos está poco estudiada por la doctrina francesa. Esta se concentra sobre los principios relativos a los ingresos públicos, y más particularmente sobre las normas relativas a los impuestos. Los gastos públicos sólo son abordados por el sesgo de sus aspectos formales, con el conjunto de principios aplicables al derecho presupuestario. Si estos últimos justifican perfectamente ese interés, no es menos cierto que cierta asimetría se hace lugar entre estos dos aspectos de las finanzas públicas: los ingresos son aprehendidos a la vez formal y materialmente, en tanto que los gastos sólo lo son desde un punto de vista estrictamente formal. ${ }^{13}$

en Historia del derecho de la hacienda pública y del derecho tributario en Italia, Italia, Temis, 2004; para España, Sainz de Bujanda, Fernando, Sistema de derecho financiero I. Introducción, Madrid, Facultad de Derecho de la Universidad Complutense, 1977, vol. Primero, en particular capítulo III "Derecho Financiero"; para Francia, Philip, Loïc, Les fondaments constitutionnels des finances publiques, París, 1995; para Argentina, Asorey, Rubén, "El derecho tributario dentro del derecho financiero", en García Belsunce, Horacio (dir.), Tratado de tributación, Buenos Aires, Astrea, 2003, t. 1, Derecho tributario, vol. 1, p. 25; para Colombia, Mauricio Plazas Vega, Derecho de la hacienda pública y derecho tributario, 3a. ed., Temis, 2016, t. I, Derecho de la hacienda pública.

12 Martínez Lago, Miguel Ángel, Ley de presupuesto y constitución, Madrid, Trotta, 1998. En Derecho constitucional presupuestario, considero que varios principios tradicionales sobre el presupuesto son aspectos del principio de reserva de ley, cap. V, "El principio de reserva de ley".

13 Valls, Julien, Le contrôle des normes législatives financières par les cours constitutionnelles espagnole et francaise, París, LGDJ, 2002, p. 107. 
Este libro forma parte del acervo de la Biblioteca Jurídica Virtual del Instituto de Investigaciones Jurídicas de la UNAM

En las visiones clásicas la ley de presupuesto sólo era objeto de un estudio en términos de competencias y procedimientos. En cambio, los tributos eran objeto de un estudio sustancial mucho más profundo. Esa asimetría hoy ya no puede sostenerse.

Uno de los momentos centrales de la historia del derecho tributario consiste en el pasaje del tributo de relación de poder a relación jurídica. El tributo, en vez de vehiculizar una relación de dominio entre el Estado y un súbdito, se materializa en una obligación jurídica sujeta a pautas constitucionales.

El desafío actual consiste en hacer ese paso en el ámbito correlativo del presupuesto del Estado. La manera oblicua de enfocar al presupuesto como pura institución de poder, consiste en considerar que el Estado tiene una total discrecionalidad al momento de decidir cómo gastar los recursos públicos. Discrecionalidad en la selección de los gastos públicos no es más que reducir el presupuesto a una relación de poder.

Se trata de que todos los contenidos materiales de la Constitución se pongan en juego para la reformulación del presupuesto público y, en profundidad, del conjunto de la hacienda pública.

\section{LA LEY DE PRESUPUESTO COMO EJE DE LA CONSTITUGióN FINANCIERA}

La institución central de la Constitución financiera es la ley de presupuesto. Lo señala con claridad Rodríguez Bereijo:

El núcleo central de la temática del derecho financiero no está constituido tanto por las relaciones jurídicas tributarias, sino también por la relación entre los ingresos y los gastos públicos, el verdadero eje central en torno al que gira el derecho financiero. Esta relación encuentra su expresión o se materializa en el presupuesto del Estado; de ahí que se haya afirmado con razón (aunque luego la doctrina no siempre haya deducido las consecuencias que lógicamente se deducen de ella), que la institución presupuestaria es la que da unidad y coherencia a la actividad financiera del Estado. ${ }^{14}$

Esta unidad se produce, a su vez, por las particularidades técnicas que caracterizan a la norma presupuestaria, como consecuencia de la historia política que le dio origen.

14 Rodríguez Bereijo, Álvaro, Introducción al estudio del derecho financiero, Madrid, Instituto de Estudios Fiscales, 1976, p. 113. 
Este libro forma parte del acervo de la Biblioteca Jurídica Virtual del Instituto de Investigaciones Jurídicas de la UNAM

Dos ideas están expresadas aquí. La primera: la singularidad técnica de la norma presupuestaria es la que le otorga un lugar preeminente en la Constitución financiera. La segunda: esa singularidad normativa tiene su origen en la historia política a través de la cual se fue gestando la institución presupuestaria tal como la conocemos hoy en día.

\section{La estructura normativa de la decisión presupuestaria}

La norma presupuestaria se caracteriza por ser la autorización legal de todos los gastos públicos, sobre la base de un cálculo de los recursos que se estiman recaudar, todo ello durante un período de tiempo.

Hay un operador deóntico (la autorización), un contenido (los gastos públicos), una forma jurídica (la ley) y una cobertura explícita (la estimación de los recursos). ${ }^{15}$

Se aprecia que este mecanismo técnico incluye la totalidad de la Hacienda Pública, ya que tienen que estar presentes, cada uno con una modalidad jurídica propia, todos los recursos y todos los gastos púbicos.

Es la única institución financiera que permite visualizar la totalidad del fenómeno financiero público. Por eso es una institución privilegiada.

El presupuesto permite ver y articular la totalidad de la actividad financiera pública.

\section{La génesis histórico-política de la ley de presupuesto como institución}

En cuanto a lo segundo, sólo cabe destacar que la institución presupuestaria se va gestando de forma simultánea al Estado constitucional de derecho y, en particular, a la configuración, con las singularidades de cada historia nacional, de la división de poderes y la apropiación de potestades por parte de los órganos parlamentarios.

Como señala Eusebio González García: "El concepto jurídico de presupuesto es una idea relativamente reciente y... su afirmación en el derecho público se corresponde al nacimiento del Estado liberal de derecho". ${ }^{16}$

15 Hay dos tareas aquí para realizar. Primero: volver a los debates de la segunda mitad del siglo XIX y de la primera del XX (sintetizados por Álvaro Rodríguez Bereijo y Eusebio González García en sus clásicos estudios sobre el presupuesto) desde nuestra renovada óptica constitucional. Segundo: tomar en cuenta el desafío que plantea la visión que intenta pensar la ley de presupuesto como una obligación.

16 González García, Eusebio, Introducción al derecho presupuestario. Concepto, evolución histórica y naturaleza jurídica, Madrid, Editorial de Derecho Financiero, 1973, p. 75. 
Este libro forma parte del acervo de la Biblioteca Jurídica Virtual del Instituto de Investigaciones Jurídicas de la UNAM

Reflexiones semejantes son expuestas en la doctrina comparada. En Francia, por ejemplo, la hace Michel Bouvier: "Los parlamentos, principalmente en Gran Bretaña y Francia conquistaron su estatus político a través de la reivindicación y afirmación de prerrogativas financieras". ${ }^{17}$

En Italia, Guido Rivosecchi: "La historia de la asamblea electiva se caracteriza esencialmente desde su origen por la reivindicación del control parlamentario sobre el indirizzo político-financiero y, fundamentalmente, sobre el ejercicio del poder de imposición fiscal y sobre la gestión del gasto público". ${ }^{18}$

Para acumular poder financiero en las manos de los parlamentos se fue construyendo la institución presupuestaria en términos de autorización legal.

Así, por ejemplo, con respecto al régimen parlamentario europeo son ilustrativos los términos empleados por el Tribunal Constitucional español en su sentencia STC 3/2003:

La competencia de aprobar los presupuestos del Estado, como referencia primera e inmediata de la configuración constitucional de nuestras Cortes Generales, tras atribuirles el ejercicio de la potestad legislativa del Estado, revela la esencialidad de la institución presupuestaria para el Estado social y democrático de Derecho en que se constituye, en el mismo art. 1.3 de la norma fundamental, la democracia parlamentaria española.

A este respecto, conviene recordar que el presupuesto nace vinculado al parlamentarismo. En efecto, el origen remoto de las actuales leyes de presupuestos hay que buscarlo en la autorización que el Monarca debía obtener de las Asambleas estamentales para recaudar tributos de los súbditos. Así, entre otros, baste recordar la garantía ofrecida por Pedro III, en 1283, a las Cortes Catalanas de Barcelona de no introducir nuevos tributos sin el consentimiento de ellas o, en un ámbito distinto al nuestro, la prohibición de la Carta Magna inglesa de 1215 que, en su art. 12, prohibía la existencia de tributos "sin el consentimiento del Consejo común". Como consecuencia directa de este principio de 'autoimposición', surgió el derecho de los ciudadanos, no sólo a consentir los tributos, sino también a conocer su justificación y el destino a que se afectaban, derechos que recogió tempranamente la Bill of Rights de 1689, expresó claramente la Declaración de los Derechos del Hombre y del Ciudadano de 1789 (art. 14) y estableció nuestra Constitución de Cádiz de 1812 (art. 131). Los primeros presupuestos, así pues, constituían la autorización del Parlamento al Monarca respecto de los ingresos que podía recaudar

17 Bouvier, Michel, Finances Publiques, 4a. ed., París, LGDJ, 1998.

18 Rivosecchi, Guido, L'indirizzo político finanziario tra Costituzione Italiana e Vincoli Europei, Cedam, 2007, p. 9. 
Este libro forma parte del acervo de la Biblioteca Jurídica Virtual del Instituto de Investigaciones Jurídicas de la UNAM

de los ciudadanos y los gastos máximos que podía realizar y, en este sentido, cumplían la función de control de toda la actividad financiera del Estado.

Así, la conexión esencial entre presupuesto y democracia parlamentaria debe ser destacada como clave para la resolución de este recurso de inconstitucionalidad. El presupuesto es, como hemos visto, la clave del parlamentarismo ya que constituye la institución en que históricamente se han plasmado las luchas políticas de las representaciones del pueblo (Cortes, Parlamentos o Asambleas) para conquistar el derecho a fiscalizar y controlar el ejercicio del poder financiero: primero, respecto de la potestad de aprobar los tributos e impuestos; después, para controlar la administración de los ingresos y la distribución de los gastos públicos.

Un juicio semejante hace Kate Stith en el contexto del derecho constitucional norteamericano, caracterizado por un régimen político de carácter presidencialista, de fuerte incidencia en el derecho público latinoamericano: ${ }^{19}$

La Constitución ubica el poder sobre la caja (the power of the purse) en el Congreso: "No puede devengarse dinero del Tesoro sino como consecuencia de una apropiación hecha por ley" (art. I, § 9, cl. 7). Este empoderamiento de la legislatura es uno de los fundamentos de nuestro orden constitucional.

O de acuerdo, en fin, a lo expuesto por la Corte Constitucional colombiana en su sentencia C-546/1996, que también se ha referido al asunto en una jurisprudencia por lo demás abundante en materia presupuestaria:

El principio de legalidad del gasto constituye uno de los fundamentos más importantes de las democracias constitucionales. Según tal principio, corresponde al Congreso, como órgano de representación plural, decretar y autorizar los gastos del Estado, pues ello se considera un mecanismo necesario de control al Ejecutivo y una expresión inevitable del principio democrático y de la forma republicana de gobierno. En el constitucionalismo colombiano, la legalidad del gasto opera en dos momentos diferenciados, pues en general las erogaciones no sólo deben ser previamente decretadas por la ley sino que, además, deben ser apropiadas por la ley de presupuesto para poder ser efectivamente realizadas. No se podrá hacer erogación con cargo al Tesoro que no se halle incluida en el presupuesto de gastos, regla que es la materialización del principio de la legalidad del gasto en el campo presupuestal. El

19 Stith, Kate, "Congress' Power of the Purse", The Yale Law Fournal, vol. 97, núm. 7, junio de 1988, p. 1343 (texto traducido en El derecho constitucional presupuestario en el derecho comparado, pp. 109 y ss.). 
Este libro forma parte del acervo de la Biblioteca Jurídica Virtual del Instituto de Investigaciones Jurídicas de la UNAM

presupuesto es una ley de autorización de gastos, por cuanto limita jurídicamente su ejecución en tres aspectos: de un lado, en el campo temporal, pues las erogaciones deben hacerse en el período fiscal respectivo; de otro lado, a nivel cuantitativo, pues las apropiaciones son las cifras máximas que se pueden erogar; y, finalmente, en el campo sustantivo o material, pues la ley no sólo señala cuánto se puede gastar sino en qué se deben emplear los fondos públicos. Por ello se considera que una obvia consecuencia de la legalidad del gasto es el llamado principio de "especialización", donde se señala que no se podrá "transferir crédito alguno a un objeto no previsto en el respectivo presupuesto". Esta norma constitucional está prohibiendo que el Gobierno utilice una partida de gasto aprobada por el Congreso para una finalidad distinta de aquélla para la cual ésta fue apropiada.

Esto es: los conceptos de ley, presupuesto y órgano parlamentario forman, por su proveniencia histórica, un tríptico político inescindible. Es al momento de ejercer la potestad presupuestaria y decidir sobre los gastos públicos cuando los órganos parlamentario-legislativos revelan uno de sus mayores poderes dentro de la estructura política del Estado.

En otros términos: autorización (el aspecto estrictamente deóntico) y forma legal (intervención del parlamento) han sido dos aspectos indisolubles de la institución presupuestaria.

\section{La doble función política de la ley de presupuesto: planificación y control}

La historia, claro está, es mucho más compleja, pues ese poder financiero ha resultado compartido y las transacciones políticas también han quedado inscritas en la técnica presupuestaria. Ante todo, los ejecutivos son los que elaboran y presentan los proyectos de ley de presupuesto, y en ese acto exponen la visión política del gobierno.

Tal como también lo resume el Tribunal Constitucional español en la mencionada STG 3/2003:

De lo anterior se deduce que, incluyendo los presupuestos generales del Estado "la totalidad de los gastos e ingresos del sector público estatal" (art. 134.2 CE) y constituyendo el "instrumento de dirección y orientación de la política económica del Gobierno", mediante su "examen, enmienda y aprobación", las Cortes Generales ejercen, como hemos dicho, una función específica y constitucionalmente definida a la que hicimos referencia en la STG 76/1992, de 14 de mayo [FJ 4 a)]. A través de ella, cumplen tres objetivos especialmente relevantes: a) Aseguran, en primer lugar, el control democrático del conjunto de la actividad financiera pública (arts. 9.1 y 66.2, 
Este libro forma parte del acervo de la Biblioteca Jurídica Virtual del Instituto de Investigaciones Jurídicas de la UNAM

ambos de la Constitución); b) Participan, en segundo lugar, de la actividad de dirección política al aprobar o rechazar el programa político, económico y social que ha propuesto el Gobierno y que los presupuestos representan; c) Controlan, en tercer lugar, que la asignación de los recursos públicos se efectúe, como exige expresamente el art. 31.2 CE, de una forma equitativa, pues el presupuesto es, a la vez, requisito esencial y límite para el funcionamiento de la Administración.

De ahí también las limitaciones que muchas Constituciones contienen sobre las potestades legislativas que pueden ejercerse respecto del proyecto de ley enviado por los poderes ejecutivos.

Pueden verse como ejemplo las Constituciones de España e Italia.

\section{La ley de presupuesto y las instituciones del Estado social y democrático de derecho}

Hoy en día el presupuesto involucra a todos los órganos públicos del Estado: a los poderes Ejecutivo, Legislativo y Judicial. Y esto, más allá de las diferencias institucionales en el derecho comparado. Es decir, más allá de la distinción entre parlamentarismo, presidencialismo y semipresidencialismo; más allá de la organización territorial (estados unitarios o federales) y más allá también de la forma de ejercer el control de constitucionalidad (difuso o concentrado, en este caso previo y/o posterior).

En primer lugar, los gobiernos son los que tienen a su cargo la elaboración del proyecto de ley de presupuesto. Los órganos Legislativos son los que deliberan y aprueban el presupuesto. Los Ejecutivos en los regímenes presidencialistas tienen el poder de veto. Los gobiernos, luego, reglamentan y ejecutan. También llevan a cabo un control interno. Las legislaturas a su vez hacen seguimientos y en su órbita actúan los órganos de control externo.

Pero a ello hay que sumar la creciente actividad de los tribunales, sean los tribunales constitucionales en los sistemas concentrados de control (España, Alemania, Italia, Francia), o los jueces en los sistemas difusos (Estados Unidos, Argentina).

Ya no hay lugar práctico para afirmar que los tribunales no conocen (y no deben conocer) sobre la materia presupuestaria en sus diversas facetas.

\section{LA REGONFIGURAGIÓN DE TODA LA LÓGICA GONSTITUCIONAL}

Ciertamente, no sólo el derecho financiero se ve afectado. Así como no puede ya pensarse el derecho financiero desde afuera de la Constitución, las 
Este libro forma parte del acervo de la Biblioteca Jurídica Virtual del Instituto de Investigaciones Jurídicas de la UNAM

instituciones constitucionales tienen que repensarse a la luz de su integración con la reflexión financiera.

Hay que dejar atrás el reduccionismo financiero (donde se piensa el presupuesto al margen de la lógica sustancial constitucional) y el idealismo constitucional (donde se piensan las instituciones al margen de cómo se financian).

Tanto la teoría de los derechos fundamentales como la teoría de la organización del poder tienen que pasar por una reflexión sobre el financiamiento.

No se trata de capítulos constitucionales que se vinculan de forma extrínseca. Por el contrario, hay una conexión íntima entre el sistema de los derechos fundamentales, la organización del poder del Estado y la mecánica de financiamiento.

Se aprecia un debate en ámbitos doctrinarios simultáneos. Con el derecho constitucional al decir: "no se puede pensar la Constitución sin incluir la reflexión sobre el financiamiento". Con el derecho financiero al conducirlo a una unidad de origen constitucional, disolviéndose así toda asimetría doctrinaria entre gastos y recursos, presupuesto y tributo.

\section{Los deberes fundamentales. La capacidad contributiva. El principio de solidaridad}

Esta reconfiguración tiene también consecuencias de largo alcance. La primera es la de enfatizar la importancia de los deberes fundamentales. El sistema constitucional de los derechos incluye deberes fundamentales. El principal es justamente de carácter financiero: el deber de contribuir.

Se trata de un deber que engloba todo el fenómeno financiero, pues, en síntesis, se trata del deber de contribuir al sostenimiento de los gastos públicos de acuerdo a la capacidad contributiva. ${ }^{20}$

Hay un aspecto tributario ("contribuir"), un aspecto presupuestario ("gastos públicos") y un concepto financiero común ("capacidad contributiva"). ${ }^{21}$ La capacidad contributiva es un concepto plenamente financiero.

El deber de contribuir a la vez se encuentra estrechamente vinculado a los deberes que surgen del principio constitucional de solidaridad o fra-

20 Casalta Nabais, José, O deber fundamental de pagar impostos, Coimbra, Livraria Almedina, 1998; Rodríguez Bereijo, Álvaro, "El deber de contribuir como deber constitucional. Su significado jurídico", Revista Española de Derecho Financiero, núm. 125, p. 5.

21 Una visión preliminar sobre la capacidad contributiva como concepto financiero puede verse en Derecho constitucional presupuestario, capítulo XIX, punto IV.4. "La capacidad contributiva como concepto constitucional financiero". 
Este libro forma parte del acervo de la Biblioteca Jurídica Virtual del Instituto de Investigaciones Jurídicas de la UNAM

ternidad, también consagrado en el derecho internacional de los derechos humanos.

\section{La interconexión entre Constitución financiera, derechos fundamentales y organización estatal}

Pero también se avanza en el proceso de interconexión de todo el derecho constitucional. Pues los derechos fundamentales para ser efectivos requieren de estructuras y de acción pública, y todo ello de financiamiento.

El derecho de la organización política del Estado (el derecho constitucional del poder) y el derecho administrativo (derecho de la organización y acción público-administrativa) están indisolublemente ligados a los derechos fundamentales y al derecho financiero.

Cabe aclarar que esta conexión se presenta, con diversos grados de intensidad, en todos los derechos fundamentales y no sólo en los derechos sociales. Es cierto, claro, que los derechos sociales requieren prestaciones y tienen costos. Pero lo mismo sucede, con diverso grado de intensidad, con la totalidad de los derechos.

En suma, hay una conexión conceptual entre a) derechos fundamentales, $b$ ) estructura y acción públicas, y c) decisión presupuestaria.

\section{El principio constitucional financiero de suficiencia}

Este enfoque permite aprehender un principio no siempre apreciado en real magnitud: el de suficiencia, que juega tanto al nivel constitucional como al administrativo (como una directiva que incide en la organización administrativa).

El principio dispone, en general, que las autoridades públicas deben tener los medios suficientes (jurídicos y materiales) para cumplir con las finalidades que les atribuye (e impone) el propio orden jurídico.

Su fundamento es la coherencia jurídica, pues si el propio orden jurídico incluye órganos (que son creaciones artificiales del derecho) y le fija misiones y funciones, también debe darle los medios para poder cumplir con dichas misiones y funciones. Hay aquí una exigencia de seriedad. Si un órgano se crea con la seria tarea de que ejerza sus competencias tiene que tener los medios, jurídicos y materiales, para hacerlo. Y uno de los medios nucleares son los financieros.

En la práctica jurídica argentina este principio revela su significación ante la problemática de los gobiernos locales (municipios) a los que se les 
Este libro forma parte del acervo de la Biblioteca Jurídica Virtual del Instituto de Investigaciones Jurídicas de la UNAM

asignan funciones y sin embargo, en general, carecen de potestades tributarias suficientes y/o transferencias suficientes de otros niveles de gobierno. $\mathrm{Si}$, por ejemplo, es una competencia municipal asegurar el derecho a la salud, entonces debe el municipio tener los medios suficientes para cumplir esa tarea. ${ }^{22}$

También se ve su relevancia cuando nos encontramos ante órganos a los que no se les dotan de recursos suficientes para llevar a cabo sus cometidos. De ahí el dictado de legislación que le asegure a ciertos órganos un porcentaje de los recursos o de los gastos a fin de aislar a dicha institución de la discrecionalidad política en la asignación. ${ }^{23}$

La suficiencia es una garantía institucional que se proyecta directamente sobre los derechos fundamentales, en la medida en que estos requieren de organización y acción pública para ser efectivos.

\section{LA APERTURA DEL DERECHO FINANCIERO}

Este marco conceptual es el que permite comprender e integrar en un estudio científico y sistemático una diversidad de fenómenos que están modificando el paisaje del derecho financiero.

Menciono algunos a título de ejemplo:

a) El derecho comunitario europeo sobre reglas presupuestarias, con una historia vertiginosa, como lo muestra la sucesiva creación del Mecanismo Europeo de Estabilidad Financiera (MESF) y el Fondo Europeo de Estabilidad Financiera, ambos de 2010; el llamado Six Pack, también en 2010 y el posterior Tratado sobre Estabilidad, Coordinación y Gobernanza de 2012. ${ }^{24}$

22 Una primera visión en Derecho constitucional presupuestario, capítulo IV, punto II, "El principio de suficiencia financiera", y punto XII, "El régimen financiero municipal".

23 Sobre la importancia del principio de suficiencia para el funcionamiento de los órganos públicos; véase CIDH, Principios básicos relativos a la independencia de las judicatura, principio 7; Declaración de Beijing sobre los principios relativos a la independencia de la judicatura, Consejo de LAWASIA, principio 37; otras referencias sobre el tema están mencionadas en Garantías para la independencia de las y los operadores de justicia. Hacia el fortalecimiento del acceso a la justicia y el Estado de derecho en las Américas, OEA/Ser. L/V/II./Documento 44, 5 diciembre 2013 (punto 49 y siguientes: "El manejo del presupuesto como un elemento de independencia"). El argumento es el siguiente: deben dotarse a operadores judiciales los recursos suficientes para que puedan asegurar adecuadamente el acceso a la justicia y el debido proceso en todas sus dimensiones procesales.

24 "Vincoli di bilancio, finanza pubblica e diritti social. Prospettive comparate: Germania, Spagna, Portogallo e Grecia" a cura di Claudia Marchese, febrero de 2016; Cec- 
Este libro forma parte del acervo de la Biblioteca Jurídica Virtual del Instituto de Investigaciones Jurídicas de la UNAM

b) La primera vertiente de reformas constitucionales, que incluyen cláusulas sustantivas (como la Constitución de España de 1978 con referencias a la equidad y a la eficiencia; la reforma constitucional argentina de 1994, donde también hay referencias a la equidad en materia presupuestaria) o cláusulas que fijan gastos prioritarios o incluso que fijan un porcentaje de gasto público con respecto a cierto derecho, tal el caso de la salud o la educación.

c) La segunda vertiente de reformas constitucionales, donde el eje pasa por la idea de equilibrio o de alguna variante de dicha idea. Esto sucede en Europa en los últimos años con las reformas constitucionales en Alemania de 2006 (sobre el federalismo) y de 2009; la reforma constitucional española de 2011, donde se modificó el artículo 135; la reforma italiana de 2012, que modificó entre otros el artículo 81, y la reforma constitucional colombiana de 2011 donde se establece el principio de sostenibilidad fiscal.

d) La crisis económica europea, en cuyo proceso de resolución se produjeron los Memorándums de Entendimiento respecto de Grecia y Portugal, ambos con efectos presupuestarios.

e) Las decisiones de los tribunales constitucionales europeos, que se involucran cada vez con más intensidad en cuestiones presupuestarias. $^{25}$

f) La importancia creciente de los principios de publicidad y transparencia, así como del derecho a acceder a información pública. Aquí juegan un rol no sólo las instituciones internacionales (OCDE, IMF) sino también la sociedad civil. ${ }^{26}$

g) La intervención de los movimientos políticos y sociales, a través fundamentalmente de los mecanismos participativos. Aquí es paradig-

cherini, Eleonora (dir.), Stato di Diritto e crisi delle finanze pubbliche, Napoli, Editoriale Scientifica, 2016.

25 Por ejemplo, para Italia véase "La tutela dei diritti e vincoli finanziari", Quaderno di giurisprudenza costituzionale a cura di Maria Fierro, Riccardo Nevola, Danilo Diaco, 2013. Para Portugal, Almeida Ribeiro, Gonçalo de y Pereira Coutinho, Luis, O Tribunal Constitucional e a crise. Ensaios críticos, Coimbra, Almedina, 2014; Reis Novais, Jorge, Em defesa do Tribunal Constitucional, Coimbra, Almedina, 2014; Ponce Sole, Juli, "El estado social y democrático de derecho ante la austeridad y los recortes sociales: la jurisprudencia del Tribunal Constitucional portugués y su interés para el caso español", ReDCE, núm. 23, enero-junio de 2015.

26 International Budget Partnership's, Open Budget Survey, disponible en: http://wrere.inter nationalbudget.org/; OCDE, Recommendation du Conseil sur la Gouvernance budgétaire, C(2015)1$\mathrm{C} / \mathrm{M}(2015) 4$, disponible en: http://wrewe.oecd.org/mena/governance/Recommandation-du-Conseilsur-la-gouvernance-budgétaire.pdf; IMF, Fiscal Transparency Code, 2014, disponible en: http://wrere. imforg/external/np/fad/trans/. 
Este libro forma parte del acervo de la Biblioteca Jurídica Virtual del Instituto de Investigaciones Jurídicas de la UNAM

mático el desarrollo del presupuesto participativo, con su ejemplo simbólico de Porto Alegre pero hoy con experiencias latinoamericanas y europeas muy diversas.

h) La elaboración del proyecto de ley de presupuesto ya no sólo desde la óptica funcional o económica, sino desde la perspectiva de los derechos humanos. ${ }^{27}$ Camino, a su vez, que se intersecta con el del análisis del presupuesto desde la perspectiva de los derechos humanos. ${ }^{28}$ $\mathrm{Y}$ también con la construcción de indicadores para medir diversos aspectos de los derechos sociales. ${ }^{29}$

i) La reflexión sobre cuestiones financieras y presupuestarias por parte de los órganos internacionales que interpretan y aplican los tratados internacionales de derechos humanos, así el Comité de los Derechos Económicos, Sociales y Culturales.

Esta multiplicidad de fenómenos tiene tres características salientes.

Primero: la presencia no sólo de los poderes Ejecutivo y Legislativo, sino de los tribunales, en su diversidad de formas institucionales.

Segundo: la presencia cada vez mayor del derecho internacional, del derecho comunitario y, por ende, de los organismos internacionales.

Tercero: la participación de la sociedad civil y de los movimientos sociales.

En conjunto revelan la apertura del derecho presupuestario, que ya desde ningún punto de vista puede ser visto como un fenómeno puramente intraestatal.

27 OACNUDH, Políticas públicas y presupuestos con perspectiva de derechos humanos, 2010, disponible en: http://ovsyg.ujed.mx/docs/biblioteca-virtual/Politicas_publicas.pdf.

28 Fundar, International Budget Project e International Human Rights Internship Program, Dignity Counts. A Guide to Using Budget Analysis to Advance Human Rights, 2004; QUB Budget Analysis Project, Budgeting for Economic and Social Rights: A Human Rights Framework, Belfast, QUB School of Law, 2010.

29 OEA, AG/RES. 2074 (XXXV-O/05), Normas para la confección de los informes periódicos previstos en el protocolo de San Salvador; CIDH, Lineamientos para la elaboración de indicadores de progreso en materia de derechos económicos, sociales y culturales, disponible en: http://wrere.cidh.org/pdf\%20 files/Lineamientos\%20final.pdf.

Laura Pautassi, "Indicadores en materia de derechos económicos, sociales y culturales. Más allá de la medición", disponible en: http://wwrederechoshumanos.unlp.edu.ar/assets/files/ documentos/indicadores-en-materia-de-derechos-economicos-sociales-y-culturales.pdf; García Cívico, Jesús, "Indicadores y eficacia de los derechos", en Bernuz Benéitez, María José y Calvo García, Manuel (eds.), La eficacia de los derechos sociales, Valencia, Tirant lo Blanch, 2014, p. 133. 
Este libro forma parte del acervo de la Biblioteca Jurídica Virtual del Instituto de Investigaciones Jurídicas de la UNAM

\section{LEY DE PRESUPUESTO Y DERECHOS HUMANOS}

Uno de las claves de la Constitución Financiera consiste en poner en un primer plano la relación conceptual entre ley de presupuesto y derechos humanos.

Tradicionalmente se consideraba que el presupuesto es una institución interna al Estado y que, por ende, no mantiene relaciones con los derechos fundamentales. Por otra parte, la decisión presupuestaria es la quintaesencia de las decisiones políticas del Estado, es decir, la de mayor discrecionalidad.

Esta imagen, sin embargo, no corresponde a la realidad presupuestaria actual (y tampoco a la realidad histórica, por lo demás). ${ }^{30}$

En la práctica jurídica contemporánea dos formas ha tenido de manifestarse la relación (problemática) entre ley de presupuesto y derechos humanos. En primer lugar, en el derecho internacional de los derechos humanos generado luego de la posguerra. En segundo lugar, en la experiencia judicial comparada.

El debate puede ser simbolizado por este diálogo imaginario, construido con fragmentos de textos de Peter Häberle y Robert Alexy. Pregunta Häberle: “¿Deben los derechos fundamentales darse sólo en la medida de la capacidad de prestaciones económicas del Estado o el Estado debe ser prestacional en la medida en que reseñan sus derechos fundamentales?". Responde Alexy: "Derechos individuales pueden tener más peso que las razones de política financiera". ${ }^{31}$

Pero también podemos acudir a debates reales como el que se ha producido entre Luigi Ferrajoli y Anna Pintore. Comienza Ferrajoli señalando que "nada impediría, por ejemplo, que constitucionalmente se establecieran cuotas mínimas de presupuesto asignadas a diversos capítulos de gastos sociales, haciéndose así posible el control de constitucionalidad de las leyes de financiamiento estatal". A ello contesta Pintore:

Ferrajoli avanza en la dirección del activismo judicial hasta el punto de proponer, como (acaso) exigida por su teoría, la constitucionalización de cuotas

30 En el caso de Argentina, por ejemplo, puede verse la jurisprudencia de la Corte Suprema sobre la ejecución de sentencias que condenan al Estado a dar sumas de dinero. Son sentencias con efectos presupuestarios y que implicaron reflexiones del tribunal sobre el presupuesto. Una visión sobre el asunto en Derecho constitucional presupuestario, capítulo XIII, "Ley de Presupuesto y Decisiones Judiciales. La construcción histórica de su vínculo (1853-1983)".

31 Häberle, Peter, "Los derechos fundamentales en el Estado de Bienestar", Pluralismo y Constitución. Estudios de teoría constitucional de la sociedad abierta, Madrid, Tecnos, 2002, p. 213; Alexy, Robert, Teoría de los derechos fundamentales, Madrid, Centro de Estudios Constitucionales, 1993, p. 495. 
Este libro forma parte del acervo de la Biblioteca Jurídica Virtual del Instituto de Investigaciones Jurídicas de la UNAM

del presupuesto estatal destinadas a la implementación de los derechos sociales, con el consiguiente sometimiento de la Ley de Presupuestos al control judicial de las leyes... Se asignaría, de esta forma, al Tribunal Constitucional la función de decidir la política económica del país, sustrayendo también ésta al poder del gobierno. Sólo nos cabe esperar que esta propuesta no salga del círculo de los filósofos políticos, que afortunadamente (al menos por ahora) carece de poder de decisión. ${ }^{32}$

\section{EL DEREGHO INTERNAGIONAL DE LOS DEREGHOS HUMANOS}

El derecho internacional de los derechos humanos (DIDH) ha desarrollado una extensa reflexión sobre la relación entre ley de presupuesto y derechos humanos, que hoy en día, además, se extiende hacia toda la política fiscal, incluyendo los tributos y la deuda pública.

La comprensión del DIDH requiere tener en cuenta: la visión general sobre los derechos contenida en el DIDH; la clasificación de las obligaciones de los Estados; la reflexión sobre el artículo 2.1. PIDESC; las actuales reflexiones en torno a los restantes aspectos de la política fiscal (tributos y deuda pública). ${ }^{33}$

Aquí veremos muy brevemente los dos últimos puntos.

El artículo 2.1. PIDESC dispone que

...cada uno de los Estados Partes en el presente Pacto se compromete a adoptar medidas, tanto por separado como mediante la asistencia y la cooperación internacionales, especialmente económicas y técnicas, hasta el máximo de los recursos de que disponga, para lograr progresivamente, por todos los medios apropiados, inclusive en particular la adopción de medidas legislativas, la plena efectividad de los derechos aquí reconocidos.

Este texto ya da por supuesto que hay una correlación conceptual entre los derechos consagrados en Pacto y los recursos financieros del Estado.

Esta cláusula fue desarrollada por la Observación General 3 del Comité DESC, que fija varios criterios interpretativos básicos, entre ellos:

32 Ferrajoli, Luigi, "Derechos fundamentales" y Pintore, Anna, "Derechos insaciables", ambos textos se encuentran en Ferrajoli, Luigi et al., Los fundamentos de los derechos fundamentales, Madrid, Trotta, 2001, libro que compendia la polémica en torno a la visión de Ferrajoli.

33 Véase, entre otros textos actuales, Saul, Ben et al., The international Covenant on Economic, Social and Cultural Rights, Oxford, Oxford University Press, 2014; Nolan, Aoife et al. (eds.), Human Rights and Public Finance. Budget \& The Promotion of Economic and Social Rights, Oregon, Hart Publishing, 2013; Balakrishnan, Radhika et al., Rethinking Economic Policy for Social Justice. The Radical Potential of Human Rights, New York, Routledge, 2016. 
Este libro forma parte del acervo de la Biblioteca Jurídica Virtual del Instituto de Investigaciones Jurídicas de la UNAM

a) Deben adoptarse medidas, y esta obligación no está sujeta a ninguna otra consideración (punto 2).

b) Las medidas también deben ser "apropiadas". Entre tales medidas se encuentran las de carácter financiero (puntos 3 a 7).

c) La progresividad no implica inacción. Implica tomar medidas de inmediato. A la vez "todas las medidas de carácter deliberadamente retroactivo en este aspecto requerirán la consideración más cuidadosa y deberán justificarse plenamente por referencia a la totalidad de los derechos previstos en el Pacto y en el contexto del aprovechamiento pleno del máximo de los recursos de que se disponga" (punto 9).

d) El punto 10 es central ya que se refiere a la obligación mínima de satisfacer el contenido esencial de los derechos y a las reglas que debe seguir el Estado si decide hacer valer la cláusula de ausencia de recursos disponibles:

10. Sobre la base de la extensa experiencia adquirida por el Comité, así como por el organismo que lo precedió durante un período de más de un decenio, al examinar los informes de los Estados Partes, el Comité es de la opinión de que corresponde a cada Estado Parte una obligación mínima de asegurar la satisfacción de por lo menos niveles esenciales de cada uno de los derechos. Así, por ejemplo, un Estado Parte en el que un número importante de individuos está privado de alimentos esenciales, de atención primaria de salud esencial, de abrigo y vivienda básicos o de las formas más básicas de enseñanza, prima facie no está cumpliendo sus obligaciones en virtud del Pacto. Si el Pacto se ha de interpretar de tal manera que no establezca una obligación mínima, carecería en gran medida de su razón de ser. Análogamente, se ha de advertir que toda evaluación en cuanto a si un Estado ha cumplido su obligación mínima debe tener en cuenta también las limitaciones de recursos que se aplican al país de que se trata. El párrafo 1 del artículo 2o. obliga a cada Estado Parte a tomar las medidas necesarias "hasta el máximo de los recursos de que disponga". Para que cada Estado Parte pueda atribuir su falta de cumplimiento de las obligaciones mínimas a una falta de recursos disponibles, debe demostrar que ha realizado todo esfuerzo para utilizar todos los recursos que están a su disposición en un esfuerzo por satisfacer, con carácter prioritario, esas obligaciones mínimas.

e) Es complementario el punto 11:

El Comité desea poner de relieve, empero, que, aunque se demuestre que los recursos disponibles son insuficientes, sigue en pie la obligación de que el Estado Parte se empeñe en asegurar el disfrute más amplio posible de los derechos pertinentes dadas las circunstancias reinantes. Más aún, de ninguna manera se 
Este libro forma parte del acervo de la Biblioteca Jurídica Virtual del Instituto de Investigaciones Jurídicas de la UNAM

eliminan, como resultado de las limitaciones de recursos, las obligaciones de vigilar la medida de la realización, o más especialmente de la no realización, de los derechos económicos, sociales y culturales y de elaborar estrategias y programas para su promoción. El Comité ya ha tratado estas cuestiones en su Observación general Núm. 1 (1989).

f) El punto 12 mantiene las obligaciones en momentos de crisis financiera:

De manera análoga, el Comité subraya el hecho de que, aun en tiempos de limitaciones graves de recursos, causadas sea por el proceso de ajuste, de recesión económica o por otros factores, se puede y se debe en realidad proteger a los miembros vulnerables de la sociedad mediante la adopción de programas de relativo bajo costo. En apoyo de este enfoque, el Comité toma nota del análisis preparado por el UNICEF con el título de Ajuste con rostro humano: protección de los grupos vulnerables y promoción del crecimiento $\{\$ 6\}$, el análisis del PNUD en Desarrollo humano: informe $1990\{\S 7\}$ y el análisis del Banco Mundial en el Informe sobre el Desarrollo Mundial, $1990\{\S 8\}$.

g) El punto 12 aclara qué son los recursos disponibles:

El Comité observa que la frase "hasta el máximo de los recursos de que disponga" tenía la intención, según los redactores del Pacto, de referirse tanto a los recursos existentes dentro de un Estado como a los que pone a su disposición la comunidad internacional mediante la cooperación y la asistencia internacionales.

Indudablemente, estas consideraciones básicas han sido profundizadas y problematizadas por plurales documentos, tanto del Comité DESC como por otros comités y otras instituciones internacionales. ${ }^{34}$

Así, por ejemplo, hay que tener en cuenta las consideraciones contenidas en los Principios de Limburgo, que resumen la doctrina internacional. Allí se sostiene:

a) La obligación del logro progresivo existe independientemente de cualquier aumento de recursos; requiere de una utilización eficaz de los recursos de que se disponga (punto 23).

34 Véase, por ejemplo, la Declaración sobre Evaluación de la obligación de adoptar medidas hasta el máximo de los recursos de que disponga de conformidad con un protocolo facultativo del Pacto, del 21 de septiembre de 2007, que ha sido tenida en cuenta por las cortes supremas de Argentina y México al tratar cuestiones presupuestarias vinculadas a los derechos a la vivienda (Argentina) y a la salud (México). 
Este libro forma parte del acervo de la Biblioteca Jurídica Virtual del Instituto de Investigaciones Jurídicas de la UNAM

b) Los Estados Partes tienen la obligación, independientemente de su nivel de desarrollo económico, de garantizar el respeto de los derechos de subsistencia mínima de todas las personas (punto 25).

c) Se debería poner fin con toda la rapidez posible a cualquier discriminación de facto que resulte de una desigualdad en el goce de los derechos económicos, sociales y culturales debido a una escasez de recursos u otros factores (punto 38).

La Declaración de Quito, por su parte, además de profundizar este camino con respecto al sistema interamericano, se refiere también a la política fiscal:

a) Con miras a procurar la plena satisfacción de los DESG se deben aplicar políticas fiscales orientadas a una redistribución equitativa del ingreso, gravando preferente y selectivamente el patrimonio, las grandes fortunas y las transacciones comerciales antes que los salarios o los ingresos del trabajo personal con impuestos indiferenciados o regresivos al consumo o al valor agregado (punto 34).

b) Un compromiso serio con las obligaciones de los Estados respecto de los DESC implica que las obligaciones de pago con los acreedores externos deben subordinarse al deber de promover el pleno acceso y disfrute por sus ciudadanos de estos derechos, de modo tal que los programas de ajuste estructural que se acuerden con los organismos financieros internacionales deben estar subordinados al desarrollo social, y en particular, la erradicación de la pobreza, la generación de empleo pleno y productivo y la promoción de la integración social con una perspectiva de género y de diversidad cultural (punto 36).

Este último camino se ha ido abriendo paso en diferentes documentos, así los informes de los sucesivos relatores especiales sobre la pobreza extrema y los derechos humanos, Magdalena Sepúlveda (A/HCR/26/28) y Philip Alston (A/HCR/29/31), punto G "Reintroducir los recursos y la redistribución en el debate sobre los derechos humanos".

También son para tener en cuenta diversas observaciones finales recientes sobre diferentes países, entre ellos Namibia, Paraguay, Guatemala, Uganda, El Salvador y Argentina. Como ejemplo pueden verse las siguientes consideraciones en las observaciones finales sobre Irlanda del 8 de julio de 2015:

Máximo de los recursos disponibles. A la vez que toma nota de la crisis económica sin precedentes que atravesó el Estado parte y de la salida del programa 
Este libro forma parte del acervo de la Biblioteca Jurídica Virtual del Instituto de Investigaciones Jurídicas de la UNAM

de rescate durante el período al que se refiere el informe, el Comité observa con preocupación que, a pesar de las transferencias sociales efectuadas por el Estado parte para mitigar las consecuencias de las medidas de austeridad: a) La respuesta del Estado parte ante la crisis se ha centrado desproporcionadamente en la introducción de recortes en el gasto público en las esferas de la vivienda, la seguridad social, la atención de la salud y la educación, sin que se alterase su régimen fiscal; b) Muchas de las medidas de austeridad se han adoptado durante la crisis y después de esta sin que se llevara a cabo una evaluación adecuada de sus repercusiones en los derechos económicos, sociales y culturales; c) Las medidas de austeridad, que siguen vigentes, han acarreado importantes consecuencias negativas para toda la población, en particular las personas y grupos desfavorecidos y marginados, en lo tocante al disfrute de sus derechos económicos, sociales y culturales; d) No se ha realizado un examen integral y basado en los derechos humanos de esas medidas desde la salida del Estado parte del programa de rescate. El Comité recomienda al Estado parte que: a) Examine, basándose en las normas de derechos humanos, todas las medidas adoptadas en respuesta a la crisis económica y financiera que siguen vigentes con miras a garantizar el disfrute de los derechos económicos, sociales y culturales. A ese respecto, señala a la atención del Estado parte su carta abierta a los Estados partes, de fecha 16 de mayo de 2012, sobre los derechos económicos, sociales y culturales en el contexto de la crisis económica y financiera, en particular los requisitos que deben cumplir las políticas de austeridad. Las políticas deben ser temporales, abarcar únicamente el período de la crisis, y ser necesarias y proporcionales. No deben dar lugar a discriminación ni a un aumento de las desigualdades. Deben prever todas las medidas posibles, incluidas medidas fiscales, para que los derechos de las personas y grupos desfavorecidos y marginados no se vean afectados de forma desproporcionada. También deben determinar el contenido básico mínimo de los derechos reconocidos en el Pacto o un nivel mínimo de protección social y garantizar la protección de ese contenido básico en todo momento. b) Vele por que las medidas de austeridad se vayan suprimiendo gradualmente y la protección efectiva de los derechos reconocidos en el Pacto se vaya reforzando en consonancia con el progreso logrado en el período de recuperación de la economía después de la crisis. c) Considere la posibilidad de revisar su régimen fiscal, con el fin de incrementar sus ingresos para restablecer los niveles de los servicios públicos y las prestaciones sociales anteriores a la crisis, de manera transparente y participativa. d) Considere la posibilidad de incluir la evaluación del impacto sobre los derechos humanos en el proceso de elaboración de políticas, en particular en relación con los derechos contemplados en el Pacto (párrafo 10). 
Este libro forma parte del acervo de la Biblioteca Jurídica Virtual del Instituto de Investigaciones Jurídicas de la UNAM

\section{Dos MOdelos DE ARGUMENTACiÓn JUdiCial}

La experiencia judicial comparada puede clasificarse sobre la base de dos modelos de argumentación diferentes que actúan como polos ideales.

En primer lugar, la argumentación que pone el énfasis en los derechos o en las pautas constitucionales.

En segundo lugar, la argumentación que pone el énfasis en las restricciones a los derechos.

El primer polo se encuentra representado por cierta corriente jurisprudencial de la experiencia judicial norteamericana en litigios estructurales. La segunda por una serie de sentencias del Tribunal Constitucional alemán.

Dado esos dos polos, puede luego organizarse la jurisprudencia comparada que se ubica entre ambos extremos.

\section{Estados Unidos: la cuestión presupuestaria en el contexto del litigio estructural}

Los litigios estructurales o casos institucionales se han desenvuelto en el derecho norteamericano en tanto derivación política-jurídica del famoso caso Brown.

¿Cuál es la característica de estos casos? En ellos se pone en juego alguna institución pública (una organización administrativa) a la luz de una cláusula constitucional, situación que conduce, ante la verificación de una inadecuación entre aquella institución y estas disposiciones constitucionales, a decisiones judiciales que condenan al Estado a modificar sus estructuras.

Son casos institucionales porque involucran una institución, y también estructurales, en la medida en que los cambios son de gran envergadura.

Como ha señalado Gerald Frug al comentar estos casos: "El cumplimiento de las órdenes judiciales requiere masivos incrementos presupuestarios para las instituciones en cuestión". 35

Uno de los casos más relevantes (un hito, en realidad, en la historia judicial norteamericana) ha sido Wyatt us. Stickney, proceso iniciado en 1970 y concluido exitosamente 33 años después, en 2003.

La situación, resumidamente expuesta es la siguiente. El punto de partida de la situación conflictiva fue de carácter tributario: la eliminación de un tributo a los cigarrillos destinado a financiar los servicios de salud mental del Estado de Alabama. Ello implicó reducciones presupuestarias y, para

35 Frug, Gerald E., "The Judicial Power of the Purse", University of Pennsylvania Law Review, vol. 126, núm. 4, abril de 1978, p. 721. 
Este libro forma parte del acervo de la Biblioteca Jurídica Virtual del Instituto de Investigaciones Jurídicas de la UNAM

emplear una expresión típica de la experiencia latinoamericana, un ajuste presupuestario en el Hospital Estatal Bryce, en Tuscaloosa, con la consiguiente reducción de profesionales y de medios materiales. La situación implicó que 5,200 pacientes vivieran en condiciones calificadas en ese momento de inhumanas. Wyatt, internado en el hospital, inicia la demanda ante un tribunal federal que declaró que las condiciones de vida en la institución no respetaban los derechos constitucionales de los pacientes a recibir un trato digno y una atención médica adecuada. La condena, además, implicó detalladas condiciones para la reformulación institucional del hospital y un largo proceso de ejecución.

Veamos el aspecto presupuestario. En una de sus decisiones, el juez Johnson destacó lo siguiente: "El fracaso de los demandados en cumplir con este fallo no puede ser justificado por una falta de fondos operativos".

Por su parte, la Corte de Apelaciones del Quinto Circuito, al confirmar la decisión del juez Johnson, señaló que la falta de recursos (the lack of resources) no es una razón jurídica suficiente para justificar el incumplimiento del fallo.

Según el comentario de Eisenberg y Yaezell:

La corte rechazó ordenar medidas específicas sobre el sustentamiento monetario para implementar los estándares, señalando que resultaba deseable la deferencia judicial frente a la prerrogativa legislativa en lo relativo al financiamiento. Indicó, sin embargo, que la falta de fondos no podía excusar un fracaso en el cumplimiento. ${ }^{36}$

Fórmulas similares fueron luego expresadas por diferentes jueces y tribunales en los diversos casos institucionales referidos a cárceles, prisiones, e instituciones hospitalarias y escolares. ${ }^{37}$ Veamos de forma ilustrativa algunas de ellas:

36 Eisenberg, Theodore y Yaezell, Stephen, "The Ordinary and The Extraordinary in Institutional Litigation", Harvard Law Review, vol. 93, núm. 3, enero de 1980, p. 465.

37 Hay dos trabajos seminales sobre el asunto: Fiss, Owen, "The Form of Justice" en The Law as it Could be, Nueva York, New York University Press, 2003, p. 1, y Chayes, Abram, "The Role of the Judge in Public Law Litigation", Harvard Law Review, 89, núm. 7, mayo de 1976, p. 1281. La literatura posterior es inmensa. Véase, por ejemplo, Colin, Diver, "The Judge as Political Powerbroker: Superintending Structural Change in Public Institutions", Virginia Law Review, vol. 65, núm. 1, febrero de 1979, p. 43; Horowitz, Donald, "Decreeing Organizational Change: Judicial Supervision of Public Institution", Duke Law fournal, vol. 1983, núm. 6, diciembre de 1983, p. 1265; Fletcher, William, "The Discretionary Constitution: Institutional Remedies and Judicial Legitimacy", The Yale Law Journal, vol. 91, núm. 4, marzo de 1982, p. 635; Sturm, Susan, "A Normative Theory of Public Law Remedies", Georgetown Law Fournal, vol. 79, junio de 1991, p. 1355; Sabel, Charles y William, Simon, 
Este libro forma parte del acervo de la Biblioteca Jurídica Virtual del Instituto de Investigaciones Jurídicas de la UNAM

- Caso Finney vs. Arkansas: "La falta de fondos no es una excusa aceptable para las condiciones inconstitucionales de encarcelación".

- Caso Wyatt vs. Aderholt: "El Estado no puede no proveer el tratamiento sólo por razones presupuestarias".

- Caso Gates vs. Collier: "La escasez de fondos no es una justificación para continuar denegando a los ciudadanos sus derechos constitucionales".

- Caso Fackson vs. Bishop: "Las consideraciones humanas y los requerimientos constitucionales hoy en día no pueden ser determinados o limitados por consideraciones basadas en dólares".

- Caso Hamilton vs. Love: "Recursos insuficientes nunca pueden ser una justificación adecuada para que el Estado prive a ninguna persona de sus derechos constitucionales".

- Caso Gates vs. Collier (esta vez la Cámara de Apelaciones):

Cuando las instituciones estatales se encuentran operando en condiciones y con prácticas inconstitucionales, la defensa de escasez de fondos y la incapacidad de la corte de distrito para ordenar asignaciones de parte de la legislatura del Estado, deben ser rechazadas por la corte federal.

Estos litigios no se limitan a la época de mayor protagonismo de los movimientos norteamericanos por los derechos civiles, desde la segunda posguerra hasta mediados de los años setenta, sino que continúan hasta el día de hoy. Incluso hay una mayor variedad de situaciones posibles. ${ }^{38}$

En efecto, mientras que en los casos antes mencionados la cuestión presupuestaria surge en el curso del litigio como eventual razón del Estado para no poder cumplir con un estándar constitucional o, incluso, una decisión judicial, hay otras causas donde lo que está en juego, centralmente y como objeto procesal, es la financiación presupuestaria de una institución.

Un ejemplo reciente de esta última situación lo muestra la larga historia del caso CFE v. State of New York.

Iniciada casi a los comienzos de los noventa y aún en curso, en la causa se debate el sistema educativo de Nueva York a la luz de la Constitución de dicho Estado que consagra el derecho a una sólida educación básica.

"Destabilization Rights. How Public Litigation Succeeds", Harvard Law Review, vol. 117, febrero de 2004, p. 1015; Schlanger, Margo, "Beyond The Hero Judge: Institutional Reform Litigation as Litigation”, Michigan Law Review, vol. 97, mayo de 1999, p. 1994.

38 Algunos casos actuales son sintetizados en Willoughby, Katherine G., Public Budgeting in Context. Structure, Law, Reform and Results, San Francisco, Jossey-Bass, 2014, cap. 8, "Public Budgeting and The Courts: Judicial Influence on Economies and Budgets", pp. 231 y ss. 
Este libro forma parte del acervo de la Biblioteca Jurídica Virtual del Instituto de Investigaciones Jurídicas de la UNAM

En una decisión fundamental (del 26 de junio de 2003) la Corte de Apelaciones se expidió en favor de CFE y consideró que la causa de la deficiente educación residía en el sistema de financiamiento. La Corte condenó al Estado a determinar el costo presupuestario de un sistema educativo acorde a la pauta constitucional.

A partir de allí la causa tomó un curso interesante, pues ante el incumplimiento del Estado en hacer una propuesta, el juez nombró un panel de árbitros, que presentó un informe donde concluyeron que el sistema escolar necesitaba un financiamiento adicional de 5,63 billones de dólares de ayuda operativa y 9,2 billones para instalaciones. Dicho informe fue aprobado por el juez, quien ordenó al Estado proveer las sumas indicadas.

La Corte de Apelaciones, luego, consideró que correspondía diferir a la legislatura la determinación presupuestaria de la suma adecuada para financiar el sistema y asegurar el derecho a una sólida educación básica.

Mientras que en ciertos casos judiciales la cuestión presupuestaria surge como argumento de la defensa del Estado a fin de justificar un incumplimiento (y allí surge el lema judicial: "la escasez de recursos no justifica la violación de un derecho"), en otros, aquella cuestión se presenta como una discusión jurisdiccional directa sobre cómo financiar una institución y así proteger debidamente un derecho.

Ambas situaciones ponen en juego no sólo a la administración en juicio, sino al propio Poder Legislativo, quien es en definitiva el órgano competente en materia financiera y presupuestaria como derivación del principio de legalidad en la materia. ${ }^{39}$

Podemos entonces identificar una visión conceptual generada en algunos tribunales norteamericanos, cuyo sentido básico puede resumirse en el siguiente lema: las restricciones presupuestarias no son por sí mismas una razón válida alegable por el Estado para justificar el daño a un derecho fundamental o el incumplimiento de un estándar constitucional.

\section{Alemania: la categoría de "la reserva de lo posible"}

La argumentación judicial puede, desde otra óptica, poner el énfasis en las restricciones financieras. Una forma particular de enfocar el asunto es a

39 Véase Schapiro, Robert, "The Legislative Injunction: a Remedy for Unconstitutional Legislative Inaction", The Yale Law Fournal, vol. 99, núm. 1, octubre de 1989, p. 231. Entre otros casos analizados se encuentra la controvertida decisión dispuesta en "Jenkins vs. Missour", donde ante el fracaso en obtener el financiamiento necesario para cumplir con una orden judicial, el juez Clark ordenó un incremento en el impuesto local a la propiedad e impuso una tasa adicional en el impuesto a las ganancias devengadas dentro del distrito. 
Este libro forma parte del acervo de la Biblioteca Jurídica Virtual del Instituto de Investigaciones Jurídicas de la UNAM

través de la categoría de la reserva de lo posible (Vorbehalt des Moglichem), que ha nacido en el derecho alemán.

El punto de partida de la categoría de la reserva de lo posible se encuentra en la clásica decisión del Tribunal Constitucional Federal alemán conocida como numerus clausus (sentencia BverfGE 33, 303), del 18 de julio de $1972 .{ }^{40}$

El objeto del juicio consistía en la valoración constitucional de las restricciones para la admisión de estudiantes que querían iniciar estudios en un campo de especialización determinado, debido al agotamiento de la capacidad para impartir una formación (numerus clausus para el estudio de medicina).

Luego de diversas consideraciones sobre los derechos fundamentales y el principio de igualdad, el Tribunal efectúa la siguiente reflexión sobre el derecho a que se creen nuevas plazas en la universidad, que por la relevancia que va a adquirir en el futuro cabe citar de forma extensa:

En tanto que los derechos de participación tampoco se encuentran restringidos de antemano a lo existente, se encuentran, sin embargo, bajo la reserva de lo posible en el sentido de lo que el particular puede exigir en forma razonable de la sociedad. Esto lo ha valorado el legislador en primer término como una responsabilidad propia, cuando para la elaboración de su presupuesto tiene que atender también a otros intereses sociales y cuando de acuerdo con la prescripción expresa del Art. 109, párrafo 2 de la ley Fundamental tiene que tener en cuenta los requisitos del equilibrio económico. A él le corresponde también la decisión sobre el alcance y las prioridades de la construcción de escuelas superiores, donde se debe tener en cuenta que la construcción y reconstrucción de universidades de conformidad con el Art. 91a de la ley Fundamental pertenecen a las funciones que deben cumplir conjuntamente la Federación y los Estados. Para estas decisiones los órganos competentes se tienen que orientar, en primer lugar, con base en las tendencias identificables de la demanda por plazas de estudio, pues una orientación basada exclusivamente en un direccionamiento inadmisible y en un examen de necesidad, sin indagar por las necesidades, podría conducir a un recorte del significado de la libre autodeterminación como elemento constitutivo del orden liberal. De otra parte, el deber constitucional tampoco obliga a que para cada aspirante se deba tener a disposición en todo momento la plaza de estudio que él desea, y de esa forma hacer depender las inversiones aplicables en el campo de las universidades exclusivamente de múltiples

40 El texto puede consultarse en recopilación de jurisprudencia del Tribunal alemán, véase Schwabe, Jürgen, Furisprudencia del Tribunal Constitucional Federal Alemán, México, Fundación Konrad Adenauer, 2009, p. 350. 
Este libro forma parte del acervo de la Biblioteca Jurídica Virtual del Instituto de Investigaciones Jurídicas de la UNAM

factores usualmente fluctuantes e influenciables por la demanda individual. Esto llevaría a una comprensión errónea de la libertad, en el caso que se reconociera que en el tiempo la libertad personal no se realiza separadamente de la capacidad funcional y de la importancia del todo, y que una concepción subjetiva ilimitada a costa de la comunidad es incompatible con la concepción del Estado social. la ley Fundamental - como en repetidas ocasiones lo ha subrayado el Tribunal Constitucional Federal con relación al derecho fundamental de la libertad general para actuar (véase bVerfGE 4, 7 [15]; 8, 274 [329]; 27, 344 [351]) - decide sobre la tensión individuo-sociedad en el sentido de la vinculabilidad y de la sujeción a la sociedad de la persona; el individuo debe aceptar, por tanto, aquellas restricciones a su libertad para actuar que el legislador, para la protección y promoción de la vida social en comunidad, prevé dentro de los límites de lo razonable, siempre y cuando se garantice la independencia de la persona.

Estas consideraciones reclaman validez en el campo de la garantía estatal del derecho de participación. Aquí el mandato de la justicia social, que se concretiza en el principio de igualdad, se opone a los medios públicos de los que se dispone limitadamente en detrimento de otros importantes intereses comunes y que en forma prevalente favorecen una parte privilegiada de la población. Al legislador, por tanto, no le puede estar prohibido orientarse también con base en las fuerzas de la necesidad a favor de diferentes profesiones, en la medida que no tenga éxito la demanda individual y la necesidad de la sociedad pueda cubrirse mediante la asesoría a los estudiantes.

Esta intrincada argumentación puede dar lugar a diferentes formas de pensar el problema, incluso opuestas en sus valoraciones y resultados.

Una de esas visiones posibles consiste en afirmar el principio de la subordinación de los derechos fundamentales a las decisiones presupuestarias legales vigentes. Se trata de una lectura legalista, restrictiva de los derechos, que vuelve a poner el eje del político en la soberanía de la ley.

Los derechos no pueden exigirse más allá de lo posible, y ello incluye lo financieramente posible. A su vez, la evaluación de este último extremo es competencia soberana (y discrecional) del legislador.

La reserva de lo posible se convierte en "reserva de financiación" o de "cajas financieras", cuya evaluación queda en las manos libres de los órganos legislativos.

Reserva de lo posible, discrecionalidad legislativa y subordinación de los derechos a las exigencias financieras son tres aspectos de una misma concepción del derecho.

Gomes Canotilho resume esta lectura posible de forma ejemplar al señalar que 
Este libro forma parte del acervo de la Biblioteca Jurídica Virtual del Instituto de Investigaciones Jurídicas de la UNAM

...en los comienzos de los setenta, P. Häberle formuló la idea de la reserva de las cajas financieras para expresar la idea de que los derechos económicos, sociales y culturales se encuentran sometidos a las capacidades financieras del Estado en la medida en que se trate de derechos a prestaciones financiadas con cargo a las arcas públicas. En la misma línea, otro iuspublicista alemán, W. Martens, reforzaba esta idea a través de expresiones plásticas que hoy son repetidas hasta la saciedad en los manuales: "Los derechos subjetivos susceptibles de realización sólo pueden ser garantizados en el ámbito de lo posible y de lo adecuado, y por este motivo se encuentran desprovistos de estatuto jurídico-constitucional". Desde entonces la reserva de lo posible (Vorbehalt des Moglichem) logró centralidad dogmática hasta el punto de oscurecer cualquier intento de renovación en el capítulo de los derechos sociales.

Preguntándose luego qué significa en rigor la expresión reserva de lo posible. Gomes Canotilho indica cuatro aspectos: a) total desvinculación jurídica del legislador; b) "tendencia hacia cero" de la eficacia jurídica de las normas constitucionales que consagran los derechos; c) gradualidad sobre la base y a partir de los límites financieros, y d) no exigibilidad judicial de las opciones legislativas, en la medida en que los programas político-legislativos no son susceptibles de control jurisdiccional. ${ }^{41}$

La introducción de la categoría de la "reserva de lo posible" es una vía argumentativa para, por un lado, reforzar la preponderancia de ley y, por otro, para dar lugar a un principio de primacía financiera, según el cual hay una dependencia presupuestaria de los derechos.

El concepto de "reserva de lo posible", luego, fue utilizado en otros casos por el Tribunal. ${ }^{42}$

\section{LA EXPERIENCIA COMPARADA ENTRE AMBOS PARADIGMAS DE ARGUMENTACIÓN}

Dentro de estas dos formas de argumentación es posible enmarcar la jurisprudencia de los propios tribunales, que ha ido generando fórmulas transaccionales, incluso, claro, en las propias experiencias nacionales que tomamos

41 Gomes Canotilho, José Joaquim, "Metodología fuzzy y camaleones normativos en la problemática actual de los derechos económicos, sociales y culturales", Revista del Instituto Bartolomé de las Casas, año 3, núm. 6, 1998, pp. 43 y ss.

42 Sandri, Andrea, "Il Vorbehalt des Möglichen nella giurisprudenza delle corti tedesche", Gruppo di Pisa; Ricardo Perlingeiro, “¿La reserva de lo posible se constituye en un límite a la intervención jurisdiccional en las políticas públicas sociales?”, Estudios Socio-furídicos, vol. 16, núm. 2, 2014, pp. 181-212. 
Este libro forma parte del acervo de la Biblioteca Jurídica Virtual del Instituto de Investigaciones Jurídicas de la UNAM

como paradigmáticos, pues estas tampoco se dejan aprehender en una formulación única. Así, en Alemania, se ha introducido el concepto de un derecho fundamental a un mínimo existencial. ${ }^{43}$

De la múltiple experiencia latinoamericana, donde hay decisiones, entre otras, de las cortes de Perú, México y Argentina, señalaremos brevemente decisiones de las cortes de Brasil y Colombia.

\section{Brasil: la reinterpretación de la reserva de lo posible y el concepto de mínimo existencial}

El punto de partida insoslayable de la práctica jurídica brasileña es la decisión del Supremo Tribunal Federal ADPF 45 MC/DF, del 4 de mayo de 2004, con el relato a cargo del ministro Celso de Mello. ${ }^{44}$

En el caso se encontraba en controversia la constitucionalidad de un veto presidencial sobre la propuesta legislativa destinada a fijar las directrices pertinentes para la elaboración de la ley de presupuesto anual para 2004 en materia de servicios de salud. Dado que luego se modificó la llamada Ley de Directrices Presupuestarias, el conflicto devino abstracto. Sin embargo, el relator del Supremo Tribunal, Celso de Melo, consideró pertinente efectuar una serie de consideraciones, justamente centradas sobre cómo interpretar la cláusula de "la reserva de lo posible".

43 Delledonne, Giacomo, “«Minimo vitale» e Stato sociale in una recente pronuncia del Tribunale costituzionale", Forum di Quaderni Costituzionali, 17 de abril de 2010; Sarlet, Ingo Wolfgang "Dignidad de la persona humana, mínimo existencial y justicia constitucional. Algunas aproximaciones y algunos desafíos", UNAM, Instituto de Investigaciones Jurídicas, 2015, p. 613; Bittner, Claudia, "Human Dignity as a Matter of Legislative Consistency in an Ideal World: The Fundamental Right to Guarantee a Subsistence Minimum in the German Federal Constitutional Court's Judgment of 9 February 2010", German Law Fournal, vol. 12/11, 2012, pp. 1941-1960; Egydy, Stefanie, "The Fundamental Right to the Guarantee of a Subsistence Minimum in the Hartz IV Decision of the German Federal Constitutional Court”, German Law Fournal, vol. 12/11, 2012, pp. 1961-1982. Leijten, Ingrid, "The German Right to an Existenzminimum, Human Dignity, and the Possibility of Minimum Core Socioeconomic Rights Protection", German Law Fournal, vol. 16/1, 2015, p. 23.

44 La bibliografía brasileña es abundante sobre el asunto. Pueden verse, entre otros, los trabajos incluidos en Sarlet, Ingo Wolfgang y Benetti Timm, Luciano (orgs.) Direitos fundamentais: orcamento e "reserva do possivel", 2a. ed. revista e ampliada, Porto Alegre, Livraria do Advogado, 2010, y las siguientes disertaciones presentadas en la Universidad Federal de Paraná: Olhares sobre o mínimo existencial em julgados brasileiros, de Claudia Honorio; A reserva do possivel na jurisdicao constitucional brasileira: entre constitucionalismo y democracia, de Ana Lucía Pretto Pereira, y A eficácia dos direitos fundamentais sociais frente à reserva do possível de Ana Carolina Lopes Olsen. 
Este libro forma parte del acervo de la Biblioteca Jurídica Virtual del Instituto de Investigaciones Jurídicas de la UNAM

Destaquemos lo central de esta decisión. Luego de referir la posibilidad de omisiones estatales inconstitucionales y de que la Constitución no puede convertirse en una mera promesa inconsecuente, señala lo siguiente:

No dejo de comprobar, sin embargo, asentada tal premisa, una significativa relevancia de lo referido a la "reserva de lo posible... especialmente con respecto a la efectivización e implementación (siempre costosas) de los derechos de segunda generación (derechos económicos, sociales y culturales), cuyo otorgamiento, por el Poder Público, impone y exige de éste prestaciones estatales positivas que concreten tales prerrogativas individuales y/o colectivas. La realización de los derechos económicos, sociales y culturales - caracterizada por la gradualidad de su proceso de concretización-, depende en gran medida de un ineludible vínculo financiero subordinado a las posibilidades presupuestarias del Estado, de tal modo que, demostrada objetivamente la incapacidad económica financiera de la persona estatal, de ésta no se podrá razonablemente exigir, considerada la limitación material referida, la inmediata efectivización de la directiva fundada en el texto de la Carta Política. No se mostrará lícito, en tanto, al Poder Público, en tal hipótesis - mediante indebida manipulación de su actividad financiera y/o político-administrativa - crear un obstáculo artificial que revele el ilegítimo, arbitrario y censurable propósito de defraudar, frustrar o tornar inviable el establecimiento y la preservación, en favor de la persona y de los ciudadanos, de mínimas condiciones materiales de existencia. Cabe advertir de ese modo que la cláusula de la "reserva de lo posible" - salvo por la ocurrencia de un justo motivo objetivamente contrastable - no puede ser invocada, por el Estado, con la finalidad de exonerarse del cumplimiento de sus obligaciones constitucionales, especialmente cuando, de esa conducta gubernamental negativa, pueda resultar la anulación o, incluso, la aniquilación de derechos constitucionales impregnados de un sentido de esencial fundamentablidad.

A ello agrega lo siguiente:

Para establecer los elementos fundamentales de esa dignidad (el mínimo existencial), se deben establecer exactamente los objetivos prioritarios de los gastos públicos. Justo después de alcanzarlos se podrá discutir, con respecto a los recursos restantes, en qué otros proyectos se deberá invertir. El mínimo existencial, como se ha visto, asociado al establecimiento de prioridades presupuestarias, es capaz de convivir productivamente con la reserva de lo posible. Véase, pues, que los condicionamientos impuestos por la cláusula de la "reserva de lo posible", al proceso de concreción de los derechos de segunda generación - de implementación siempre costosa-, se traducen en un binomio que comprende, de un lado, 1) la razonabilidad de la pretensión individual/ social deducida frente al Poder Público y, por otro, 2) la existencia de dispo- 
Este libro forma parte del acervo de la Biblioteca Jurídica Virtual del Instituto de Investigaciones Jurídicas de la UNAM

nibilidad financiera del Estado para hacer efectivas las prestaciones positivas reclamadas. Es necesario enfatizar, considerando el encargo gubernamental de hacer efectiva la aplicación de los derechos económicos, sociales y culturales, que los elementos que componen el mencionado binomio (razonabilidad de prestación + disponibilidad financiera del Estado) deben configurarse de un modo afirmativo y en situación de acumulativa ocurrencia, pues, ausente cualquiera de estos elementos, se limitarían las posibilidades estatales de realización práctica de tales derechos. Si bien la formulación y la ejecución de políticas públicas depende de opciones políticas a cargo de aquellos que, por delegación popular, reciben investidura en mandato electivo, cabe reconocer que no se revela absoluta, en ese dominio, la libertad de conformación del legislador, ni la actuación del Poder Ejecutivo. Si tales Poderes del Estado actuaran de modo irrazonable o procedieran con una clara intención de neutralizar, comprometiendo la eficacia de los derechos sociales, económicos y culturales, afectando, como resultado causal de una injustificable inercia estatal o de un abusivo comportamiento gubernamental, ese núcleo intangible que comprende un conjunto irreductible de condiciones mínimas necesarias de una existencia digna y esenciales a la propia supervivencia del individuo, allí entonces, se justificaría, como he enfatizado ya anteriormente, - $-\mathrm{y}$ asimismo por razones fundadas en un imperativo ético jurídico - la posibilidad de intervención del Poder Judicial, a fin de viabilizar, a todos, el acceso a los bienes cuyo goce les ha sido injustificadamente denegado por el Estado.

Esta sentencia le da mayores precisiones a la visión genérica del tribunal alemán, que pueden resumirse, a mi entender, en las siguientes proposiciones:

a) La cláusula de la reserva de lo posible no puede ser articulada para justificar el incumplimiento de obligaciones constitucionales vinculadas a los derechos fundamentales que protegen las condiciones materiales mínimas para una existencia digna.

b) Los derechos económicos, sociales y culturales de rango constitucional imponen prioridades presupuestarias a los gastos públicos.

c) En este ámbito la libertad de configuración del legislador se encuentra acotada por la Constitución.

d) La invocación de la cláusula de la reserva de lo posible, en las restantes situaciones, requiere una comprobación objetiva de las incapacidades financiera del Estado.

e) La comprobada limitación presupuestaria sólo justifica, para esos casos, que la efectivización del derecho no sea inmediata.

f) El legislador actúa de manera irrazonable cuando por omisión (inercia) u acción afecta el núcleo intangible que hace a la sustancia del 
Este libro forma parte del acervo de la Biblioteca Jurídica Virtual del Instituto de Investigaciones Jurídicas de la UNAM

conjunto irreductible de condiciones mínimas necesarias para una existencia digna.

g) Todos estos elementos son los que le permite decir a la sentencia que el mínimo existencial, asociado a unas respectivas prioridades presupuestarias, puede convivir con la cláusula de la reserva de lo posible.

A fin de ver de qué manera se concreta esta visión cabe considerar los derechos que han sido incluidos dentro de ese "conjunto irreductible de condiciones" que hacen al concepto de "mínimo existencial".

Ha habido hasta el presente al menos dos situaciones paradigmáticas: el derecho a la salud y el derecho al acceso a la educación inicial.

En cuanto al derecho a la salud el Supremo Tribunal Federal se expidió en un caso pionero, RE 271.286/RS, Rel. Min. Celso de Mello, que abrió el camino para la jurisprudencia posterior:

El derecho público subjetivo a la salud representa una prerrogativa jurídica no disponible asegurada a la generalidad de las personas por la propia Constitución de la República (art. 196). Traduce el bien jurídico constitucionalmente tutelado, por cuya integridad debe velar, de manera responsable, el Poder Público, a quien incumbe formular e implementar políticas sociales y económicas idóneas que tiendan a garantizar a los ciudadanos, inclusive a aquellos portadores del virus HIV, el acceso universal e igualitario a la asistencia farmacéutica y médico-hospitalaria. El derecho a la salud además de calificarse como derecho fundamental que asiste a todas las personas, representa la consecuencia constitucional indisociable del derecho a la vida. El Poder Público, cualquiera que sea la esfera institucional de su actuación en el plano de la organización federativa brasilera, no puede mostrarse indiferente al problema de la salud del pueblo, bajo pena de incurrir, incluso por medio de una censurable omisión, en un grave comportamiento inconstitucional.

El carácter programático de la regla inscripta en el art. 196 de la Carta Política, que tiene por destinatarios todos los entes políticos que componen, en el plano institucional, la organización federativa del Estado brasileño, no puede convertirse en promesa constitucional inconsecuente, so pena de que el Poder Público, traicionando las justas expectativas depositadas por la comunidad, sustituya, de manera ilegítima, el cumplimiento de su impostergable deber, por un gesto irresponsable de infidelidad gubernamental, ante la propia Ley Fundamental del Estado.

El reconocimiento judicial de la validez jurídica de programas de distribución gratuita de medicamentos a personas carentes, inclusive aquellas portadoras del virus HIV, le otorga efectividad a preceptos fundamentales de la Constitución de la República (arts. 5o. caput, y 196) y representa, en la concreción de su alcance, un gesto reverente y solidario de aprecio a la vida y 
Este libro forma parte del acervo de la Biblioteca Jurídica Virtual del Instituto de Investigaciones Jurídicas de la UNAM

a la salud de las personas, especialmente de aquellas que nada tienen y nada poseen, salvo la conciencia de su propia humanidad y de su esencial dignidad.

En cuanto al derecho a la educación infantil es ilustrativa la sentencia AG REG Recurso Extraordinario 410.715-5 Sao Pablo, donde se dice:

La educación infantil representa una disposición constitucional indisponible, que, referida a los niños, les asegura, para su desarrollo integral, y como primera etapa del proceso de educación básica, atención en jardines de infantes y el acceso al pre-escolar (CF, art. 208, IV). Esta disposición jurídica, en consecuencia, impone, al Estado, por efecto de la enorme significación social que reviste la educación infantil, la obligación constitucional de crear condiciones objetivas que posibiliten de manera concreta, en favor de los "niños de cero a seis años de edad" (CF, art. $208 \mathrm{IV}$ ), el efectivo acceso y atención en jardines de infantes y al pre-escolar, so pena de configurarse una inaceptable omisión gubernamental, capaz de frustrar injustamente, por inercia, el integral otorgamiento, por el Poder Público de la prestación estatal que le impone el propio texto de la Constitución Federal.

La educación infantil, por calificarse como un derecho fundamental de todo niño, no se expone en su proceso de concreción a decisiones meramente discrecionales de la Administración Pública, ni se subordina a razones de puro pragmatismo gubernamental.

Los Municipios, que actúan prioritariamente en la educación fundamental y en la educación infantil (CF, art. 211, § 2o.), no pueden renunciar a su mandato constitucional, jurídicamente vinculante, que les fue otorgado por el Art. 208 IV de la Ley Fundamental de la República, y que representa un factor de limitación de la discrecionalidad político-administrativa de los entes municipales, cuyas opciones, tratándose de la atención de los niños en crecimiento (GF, art. 208, IV), no pueden ser ejercidas de modo de comprometer, sobre la base de simples juicios de conveniencia o de mera oportunidad, la eficacia de ese derecho básico de índole social. Sin perjuicio de que la prerrogativa de formular y ejecutar políticas públicas resida primariamente en los poderes legislativo y ejecutivo, es posible, sin embargo, que el Poder Judicial determine, si bien en situaciones excepcionales, especialmente en las hipótesis de políticas públicas definidas por la propia Constitución, que aquellas sean implementadas por los órganos estatales incumplidores cuya omisión - por resultar un incumplimiento de los encargos políticos jurídicos que sobre ellos inciden con carácter obligatorio - se muestra apta para comprometer la eficacia y la integridad de derechos sociales y culturales de carácter constitucional.

En esta línea, como última referencia jurisprudencial brasileña, es sumamente ilustrativa la decisión de George Marmelstein Lima, juez federal de Ceará, quien señala: 
Este libro forma parte del acervo de la Biblioteca Jurídica Virtual del Instituto de Investigaciones Jurídicas de la UNAM

La efectivización judicial del derecho a la salud implica muchas veces la llamada reserva de lo posible, que es un postulado según el cual el cumplimiento de las decisiones que impliquen gastos públicos se hace depender de la existencia de medios materiales disponibles para su implementación. ${ }^{45}$

\section{La argumentación de la sentencia al respecto es la siguiente:}

Los alegatos que niegan la efectivización de un derecho social sobre la base de un argumento de la reserva de los posible, deben ser siempre analizados con desconfianza. No basta simplemente alegar que no existen posibilidades financieras de cumplir una orden judicial; es preciso demostrarla. No se puede dejar que la invocación de la reserva de lo posible se convierta "en una verdadera razón de Estado económica, que opere en verdad como una antiConstitución contra todo lo que la Carta consagra en materia de derechos sociales" (Farena, Duciran Van Marsen. A Saúde na Constituição Federal, p. 14. In: Boletim do Instituto Brasileiro de Advocacia Pública Pública, núm. 4, 1997 , p. 12/14).

En el presente caso, lo que se observa a través de las noticias de los diarios presentados por el Ministerio Público Federal es que las autoridades responsables están eludiendo cumplir la orden judicial, alegando que no poseen recursos para implementarla. Se llega a alegar, inclusive, que no hay recursos presupuestarios previstos para sostener en el tratamiento de los pacientes en hospitales particulares. Ese alegato es insustentable. ${ }^{46}$

Esta interpretación fue luego sostenida por el propio Superior Tribunal, en la STA 278-6 Alagoas, del 22 de octubre de 2008, Relator Gilmar Mendes.

45 Justica Federal No Ceará, 3a. Vara, decisión del 23 de abril de 2003, que figura como anexo de su disertación de maestría en la Facultad de Derecho de la Universidad de Ceará, Efetivação judicial dos direitos econômicos, sociais e culturais, 2005.

46 Consideraciones semejantes ya había expresado el magistrado en su Curso de Direitos Fundamentais, São Paulo, Atlas, 2008: "A pesar de que la reserva de lo posible es una limitación lógica a la posibilidad de efectivización judicial de los derechos socioeconómicos, se observa una banalización del discurso por parte del Poder Público cuando se defiende en juicio, sin presentar elementos concretos con respecto a la imposibilidad material de cumplir la decisión judicial. Por eso, los alegatos que niegan la efectivización de un derecho económico, social y cultural sobre la base del argumento de la reserva de lo posible deben ser siempre analizados con desconfianza. No basta simplemente alegar que no hay posibilidades financieras para cumplir una orden judicial; es necesario demostrarla... Así, el argumento de la reserva de lo posible solamente debe ser acogido si el Poder Público demuestra suficientemente que la decisión causará más daños que ventajas a la efectivización de los derechos fundamentales. Vale enfatizar: la carga de la prueba de que no hay recursos para realizar los derechos sociales es del Poder Público. Es él quien debe traer al expediente los elementos presupuestarios y financieros capaces de justificar, eventualmente, la no efectivización del derecho fundamental". 
Este libro forma parte del acervo de la Biblioteca Jurídica Virtual del Instituto de Investigaciones Jurídicas de la UNAM

De las anteriores consideraciones se desprende, como señala Fernando Facury Scaff en su contribución al homenaje al profesor Ricardo Lobo Torre, que la libertad de configuración del legislador en materia presupuestaria se encuentra limitada por los derechos fundamentales establecidos en la Constitución. Y que la cláusula de la reserva de lo posible no puede ser un obstáculo para el goce de las condiciones mínimas que hacen a una vida digna. ${ }^{47}$

Se ve la riqueza de la práctica jurídica brasileña, donde hay variados aspectos que son tenidos en cuenta. Ante todo, hay un reconocimiento de que los derechos fundamentales limitan al legislador, incluso en materia presupuestaria. Como destaca Ana Paula de Barcellos: "las elecciones en materia de gastos públicos no constituyen un tema integralmente reservado a la deliberación política; al contrario, reciben una importante incidencia de normas jurídicas constitucionales". ${ }^{48}$ También tiene su lugar la reserva de lo posible, en cuanto limitación (externa) a los derechos, derivada de las restricciones financieras. Pero también juega el concepto de mínimo existencial, en cuanto núcleo de condiciones mínimas que hacen a la vida digna. Y tal como señala Ricardo Lobo Torres, "la protección positiva del mínimo existencial no se encuentra bajo la reserva de lo posible, pues su goce no depende del presupuesto ni de políticas públicas". ${ }^{9}$

En suma, el pensamiento aquí resumido se abre hacia el camino de la ponderación de varios principios y conceptos constitucionales, donde lo que queda claramente protegido, y sustraído con claridad de la discrecionalidad legislativa, es el mínimo existencial vinculado a la vida digna.

\section{Colombia: la cuestión presupuestaria y el estado de cosas inconstitucional}

La Constitución colombiana de 1991 (así como la Constitución brasileña de 1978 y la reforma constitucional argentina de 1994) ha dado lugar a una novedosa praxis jurisdiccional. ${ }^{50}$ En ese camino la Corte Constitucional

47 Facury Scaff, Fernando, "Reserva do Possível, mínimo existencial e direitos humanos", en Rodríguez Pires, Adilson y Taveira Torres, Heleno, Princípio de Direito Financiero y Tributario. Estudos em homenagem ao Profesor Ricardo Lobo Torres, Río de Janeiro, Renovar, 2006, p. 115.

48 Barcellos, Ana Paula de, "Neoconstitucionalismo, direitos fundamentais e controle das políticas públicas”, Revista de Direito Administrativo, núm. 240, abril-junio de 2005, p. 83.

49 Lobo Torres, Ricardo, "O mínimo existencial, os directos sociais e os desafios de naturaza orcamentaria" en Sarlet y Benetti Timm, op. cit., p. 75.

50 Sobre el proceso constituyente y la posterior actividad interpretativa judicial pueden verse, entre otros, los ensayos de Cepeda Espinosa, Manuel José, Polémicas constitucionales, Bogotá, Legis, 2007. 
Este libro forma parte del acervo de la Biblioteca Jurídica Virtual del Instituto de Investigaciones Jurídicas de la UNAM

se vio enfrentada a la cuestión presupuestaria, central en una serie de casos vinculados a los derechos de los desplazados. ${ }^{51}$

Un caso al respecto decisivo es el testimoniado en la sentencia T-025/04, donde se declaró el estado de cosas inconstitucional con relación a la situación de los desplazados y donde jugó un lugar central la problemática presupuestaria. Veamos los puntos esenciales.

Una gran cantidad de desplazados solicitaron judicialmente la protección de sus derechos. Las instancias anteriores a la Corte habían rechazado las solicitudes, entre otras razones, porque "no existe disponibilidad presupuestal para atender la solicitud". Sostuvieron, además, que las limitaciones presupuestarias no se pueden salvar por medio de acciones de tutela, que los jueces no son ordenadores del gasto ni coadministradores de la gestión del Ejecutivo y que, en fin, los jueces no pueden ordenar a las autoridades públicas que lleven a cabo actos para los que no tienen los recursos necesarios.

La visión de la Corte, en cambio, se desarrolló por otros andariveles.

En primer lugar señaló que la causa de los bajos resultados de la respuesta estatal a la situación de las poblaciones desplazadas de forma forzosa son la precariedad institucional y "la asignación insuficiente de recursos". Según la Corte, el nivel de recursos asignados es insuficiente y muy inferior al necesario para proteger los derechos fundamentales de las personas desplazadas.

Es interesante ver que el legislador, por medio de la ley 387, había calificado a las políticas para solucionar el asunto como prioritarias, sin condicionar el cumplimiento de las prestaciones a la disponibilidad de los recursos. Así, el Consejo allí mencionado tiene como función la de garantizar la asignación presupuestal de los programas. Sin embargo, el posterior decreto reglamentario condicionó las prestaciones a la disponibilidad presupuestal. De igual manera, las leyes de presupuesto asignaron menos recursos de los necesarios. Ante ello, la Corte señaló que "la ley presupuestal carece de la especificidad material necesaria para poder ser considerada como una modificación de los mandatos concernientes a la ayuda a las víctimas de los desplazamientos y a los derechos judicialmente reconocidos".

51 Una visión general sobre el asunto puede verse en Beatriz Londoño Toro y Rafael Pizarro Nevado (comps.), Derechos humanos de la población desplazada en Colombia. Evaluación de sus mecanismos de protección, Universidad del Rosario, 2005. En cuanto a los casos de la Corte que involucran una cuestión presupuestaria ver el cuadro general presentado por Mauricio Plazas Vega en Del realismo al trialismo jurídico..., cit., en particular su capítulo I, "El nuevo derecho y el poder de los jueces en general y de la Corte Constitucional en particular", donde formula diversas preguntas que están en el centro de nuestro ensayo (ver fundamentalmente la enumeración de interrogantes de pp. 78 y 79). 
Este libro forma parte del acervo de la Biblioteca Jurídica Virtual del Instituto de Investigaciones Jurídicas de la UNAM

También es muy claro el principio general sentado por la Corte: "Desde el punto de vista constitucional es imperioso destinar el presupuesto necesario para que los derechos fundamentales de los desplazados tengan plena realización".

Esto significa que las autoridades públicas deben hacer, "en un plazo razonable, y dentro de sus competencias, los correctivos que aseguren una suficiente apropiación presupuestal".

El carácter estructural del problema llevó a la Corte a declarar el "estado de cosas inconstitucional", uno de cuyos elementos es de carácter presupuestario. Según la propia elaboración de la Corte, se da un estado de cosas inconstitucional, si se presentan los siguientes factores: $a$ ) una vulneración masiva y generalizada de varios derechos constitucionales que afecta a un número significativo de personas; $b$ ) una prolongada omisión de las autoridades públicas en el cumplimiento de sus obligaciones para garantizar los derechos; c) la adopción de prácticas inconstitucionales, como la incorporación de acciones judiciales como parte de los procedimientos habituales para garantizar derechos; $d$ ) el no dictado de las medidas legislativas, administrativas o presupuestarias que sean necesarias para evitar la lesión de los derechos; $e$ ) la existencia de un problema social cuya solución compromete a varias entidades públicas y exige un nivel de recursos que demanda un esfuerzo presupuestal adicional; $f$ ) si todas las personas afectadas acudieran a la vía judicial se produciría una mayor congestión judicial.

Según el relato de la Corte, en los casos en que se declaró el estado de cosas inconstitucional se ordenó, en lo que a nosotros ahora interesa y con respecto a los derechos vulnerados, que se "apropien los recursos necesarios para garantizar la efectividad de tales derechos".

Lo interesante para ver es que esto es el comienzo de la argumentación de la Corte, que es rica en matices y reflexiones.

Ante todo señaló que las acciones positivas vinculadas a los derechos pueden desarrollarse progresivamente, "siempre que los mínimos de satisfacción hayan sido asegurados para todos".

Dos ideas convergen aquí: el desarrollo progresivo y el mínimo garantizado.

Claro que el desarrollo progresivo "no puede quedar indefinidamente aplazado en la agenda estatal" y, a la vez, no resultan legítimas las medidas ostensiblemente regresivas.

En el caso y según diversos informes que se citan en la sentencia, la situación de los derechos de los desplazados se ha ido agravando a lo largo del tiempo, produciéndose un claro retroceso que prima facie la Corte califica de inconstitucional. 
Este libro forma parte del acervo de la Biblioteca Jurídica Virtual del Instituto de Investigaciones Jurídicas de la UNAM

En el curso de dicha argumentación la Corte esboza un principio de coherencia entre derechos fundamentales, políticas públicas y recursos financieros:

La seriedad demanda que cuando una política sea articulada en un instrumento jurídico, como una ley o un decreto, se respete la fuerza normativa, no política ni retórica, de dichos instrumentos y por lo tanto se definan los alcances de los derechos reconocidos y se precise el contenido de las correspondientes obligaciones estatales. La coherencia apunta a que exista concordancia entre, de un lado, lo que "promete" el Estado y, de otro lado, los recursos económicos y la capacidad institucional para cumplir lo prometido, máxime si las promesas se han transformado en normas jurídicas. La coherencia exige que si el Estado crea un derecho prestacional específica por la vía de una ley, prevea que debe contar con los recursos para garantizar sus goce efectivo y con la capacidad institucional para atender la demanda de servicios generada por la creación de ese derecho específico (punto 8.3.1).

Ahora bien, sentado ello, y en términos que evocan la jurisprudencia alemana sobre la reserva de lo posible, la Corte no deja de reconocer que

...en algunas circunstancias puede ser imposible lograr, aún en el mediano plazo, esa coherencia. De constatarse que ello es así, es necesario ajustar lo prometido a lo realizable, lo cual podría representar la adopción de una medida que reduzca el alcance de la protección previamente establecida. Sin embargo, dicha medida debe cumplir estrictos requisitos, en especial asegurar los mínimos de satisfacción del derecho limitado y no desconocer las áreas prioritarias que tienen mayor impacto sobre la población.

De forma análoga a la jurisprudencia brasileña, la Corte colombiana va de las restricciones (el ámbito de lo posible) a las exigencias basadas en la idea de mínimo garantizado y, agrega, en la consideración de áreas y/o personas prioritarias.

Como señala más adelante la Corte en un párrafo clave: hay una diversidad de aspectos a considerar que exige recurrir a una tarea de ponderación. Dice la Corte:

Sin embargo, dadas las magnitudes actuales del problema de desplazamiento en Colombia, así como el carácter limitado de los recursos con los que cuenta el Estado para satisfacer ese cometido, es forzoso aceptar que al momento de diseñar e implementar una determinada política pública de protección a la población desplazada, las autoridades competentes deben efectuar un ejercicio de ponderación y establecimiento de áreas prioritarias en las cuales se 
Este libro forma parte del acervo de la Biblioteca Jurídica Virtual del Instituto de Investigaciones Jurídicas de la UNAM

prestará atención oportuna y eficaz a las personas. Por lo tanto, no siempre se podrá satisfacer, en forma concomitante y hasta el máximo nivel posible, la dimensión prestacional de todos los derechos constitucionales de toda la población desplazada, dadas las restricciones materiales y las dimensiones reales de la evolución del fenómeno del desplazamiento.

$\mathrm{El}$ argumento tiene varios pasos. Ante todo, hay derechos que deben ser asegurados en su ejercicio. Luego, la gravedad del problema y las restricciones (entre ellas presupuestarias) pueden justificar una menor protección y la fijación de prioridades. Sin embargo, tercer paso importante del argumento, existen ciertos derechos mínimos de la población desplazada que deben ser satisfechos en cualquier circunstancia.

La Corte señala a su vez varios elementos para definir ese mínimo. Así, en ningún caso se puede lesionar el núcleo esencial de los derechos fundamentales constitucionales de las personas desplazadas. También deben asegurarse los derechos de contenido prestacional que guarden estrecha relación con la preservación de la vida en circunstancias elementales de dignidad como seres humanos distintos y autónomos. ${ }^{52}$ Estas consideraciones genéricas se concretan en un listado de derechos mínimos que integran "el mínimo prestacional que siempre debe ser satisfecho por el Estado": los derechos a la vida; a la dignidad y a la integridad física; a la familia y a la unidad familiar; a una subsistencia mínima como expresión del derecho fundamental al mínimo vital (que incluye alimentos esenciales, agua potable, alojamiento y vivienda básicos, vestidos apropiados y servicios médicos y sanitarios esenciales); a la salud; a la protección frente a prácticas discriminatorias; a la educación básica hasta los quince años; de apoyo para el autosostenimiento; de retorno y reestablecimiento en su lugar de residencia.

En su decisión la Corte declara el estado de cosas constitucional y ordena el diseño de un plan para superar la discordancia entre los derechos reconocidos y los recursos financieros efectivamente destinados. En ese camino las autoridades competentes deben "fijar la dimensión del esfuerzo presupuestal que es necesario para cumplir con la política pública encaminada a proteger los derechos fundamentales de los desplazados" y, luego "realizarán todos los esfuerzos necesarios para asegurar que la meta presupuestal por ellos fijados se logre". Por otra parte, se debe prever un plan de contingencia y, a la vez, si no es posible asegurar el volumen de recursos

52 Sobre las peculiaridades del concepto de derecho fundamental en el derecho constitucional colombiano, véase Chinchilla, Tulio, ¿Qué son y cuáles son los derechos fundamentales?, 2a. ed., Bogotá, Temis, 2009. Un enfoque más general puede verse en Arango, Rodolfo, El concepto de derechos sociales fundamentales, Bogotá, Legis, 2005. 
Este libro forma parte del acervo de la Biblioteca Jurídica Virtual del Instituto de Investigaciones Jurídicas de la UNAM

establecidos se deberá redefinir la política y diseñar las modificaciones necesarias, todo ello asegurando el goce efectivo de los mínimos indicados con anterioridad.

Es de interés para nuestro trabajo la siguiente reflexión de la Corte, que se hace cargo de la eventual crítica de estar invadiendo las competencias (así las presupuestarias) de los otros poderes del Estado:

Estas órdenes están dirigidas a que se adopten decisiones que permitan superar tanto la insuficiencia de recursos, como la falencia en la capacidad institucional. Ello no implica que por vía de tutela, el juez esté ordenando un gasto no presupuestado o esté modificando la programación presupuestal definida por el Legislador. Tampoco está delineando una política, definiendo nuevas prioridades, o modificando la política diseñada por el Legislador y desarrollada por el Ejecutivo. La Corte teniendo en cuenta los instrumentos legales que desarrollan la política de atención a la población desplazada, el diseño de esa política y los compromisos asumidos por las distintas entidades, está apelando al principio constitucional de colaboración armónica entre las distintas ramas del poder para asegurar que el deber de protección efectiva de los derechos de todos los residentes del territorio nacional, sea cumplido y los compromisos definidos para tal protección sean realizados con seriedad, transparencia y eficacia.

Por cierto, el problema de los desplazados, por su propio carácter estructural, ha generado un complejo proceso jurisprudencial que no se agota en la sentencia que comentamos.

De las diversas decisiones posteriores cabe señalar, por su directa vinculación con nuestro tema, lo resuelto en dos acciones de tutela donde la Corte expresó, de forma nítida, "que resulta inaceptable, desde el punto de vista constitucional, que se aduzca insuficiencia presupuestal, en este o en otro caso, para abstenerse de proteger derechos fundamentales". ${ }^{53}$

\section{SiSTEMATIZACIÓN DE LA PROBLEMÁTICA PRESUPUESTARIA EN LOS PROCESOS JUDICIALES}

Las diversas experiencias antes reseñadas son un indicio de la complejidad que caracteriza al triángulo conceptual ley de presupuesto, derechos humanos y práctica judicial.

53 Sentencia del 22 de mayo de 2003, dictada en los expedientes acumulados T-696168 y T-696652. 
Este libro forma parte del acervo de la Biblioteca Jurídica Virtual del Instituto de Investigaciones Jurídicas de la UNAM

No sólo estamos lejos de lo que ya podemos calificar como el mito de la exclusión del conocimiento judicial de las cuestiones de índole presupuestaria, sino que, por el contrario, ellas tienen una diversidad tal que son susceptibles de diversos tipos de análisis.

Hay por lo menos dos dimensiones procesales a tener en cuenta: la cuestión presupuestaria y los efectos presupuestarios de las sentencias.

\section{La cuestión presupuestaria}

Llamamos cuestión presupuestaria a la vinculación entre $a$ ) un derecho humano o una pauta constitucional, y $b$ ) una exigencia y/o restricción presupuestaria.

Esta cuestión puede estar implícita en un proceso o ser explicitada.

Cuando está implícita significa que estamos ante un problema judicial que involucra una cuestión presupuestaria, pero ésta no es considerada por ningún sujeto del proceso, sean las partes o el propio órgano judicial. Un caso típico y habitual son las acciones contra el Estado por daños y perjuicios por responsabilidad extracontractual. Puede ser que todo el juicio se desarrolle y en su curso no surja en ningún momento que la resolución a dictarse o ya dictada tiene efectos presupuestarios.

Las cuestiones explícitas, por su parte, son las que permiten una clasificación más rica de situaciones. Hay dos grandes grupos de casos: la cuestión presupuestaria como objeto del proceso y la cuestión como defensa del Estado.

Cuando es objeto del proceso, la cuestión presupuestaria puede surgir a su vez de dos maneras posibles. En primer lugar, están las situaciones en las cuales el propio Estado alega una razón presupuestaria para justificar una medida por ejemplo legislativa. En estos casos controvertir ante los tribunales esa medida, implica de suyo poner en el centro del debate aquellas razones presupuestarias. Esta situación es habitual cuando los Estados implementan planes de ajuste o de austeridad. En segundo lugar, se encuentran los casos en los cuales quien demanda al Estado sostiene que la lesión al derecho está causada por restricciones presupuestarias. Esto sucede, por ejemplo, en el caso CFE v. State of New York antes mencionado.

Por otro lado tenemos la cuestión presupuestaria en cuanto defensa del Estado. Aquí a su vez hay dos situaciones básicas. La primera, cuando la defensa del Estado es alegada durante el proceso. Es decir, el Estado sostiene durante el juicio la carencia de recursos para justificar un incumplimiento o, en su caso, el grado de cumplimiento que considera posible. La 
Este libro forma parte del acervo de la Biblioteca Jurídica Virtual del Instituto de Investigaciones Jurídicas de la UNAM

segunda, durante la ejecución de la sentencia. Ya condenado el Estado, este sostiene que no puede cumplir por las restricciones presupuestarias. En este momento de la ejecución el Estado a su vez puede esgrimir la restricción presupuestaria para limitar su cumplimiento en un aspecto cuantitativo (no puede cumplir todo lo que se le ordena) o temporal (no pude cumplir en los plazos fijados).

En los dos casos de defensa (durante el proceso o durante la ejecución) la restricción presupuestaria alegada por el Estado puede estar basada en una legislación expresa o, en su defecto, tratarse de una argumentación puramente conceptual.

\section{Los efectos presupuestarios de las decisiones judiciales}

Las decisiones de los tribunales que condenan al Estado pueden tener, o no, efectos presupuestarios. Nuestro interés aquí consiste en clasificar a estas últimas.

Hay tres tipos de decisiones relevantes: las que imponen una obligación de dar una suma de dinero, las que imponen una obligación de hacer y las que invalidan actos o normas jurídicas.

Las decisiones judiciales que imponen la obligación de dar una suma de dinero son las más habituales en los juicios que se entablan contra los Estados. Su efecto presupuestario surge de manera inmediata. Sin perjuicio de otras situaciones, hay cinco tipos de decisiones significativas: a) las sentencias en acciones de repetición, donde se acredita que un contribuyente efectuó un pago tributario sin causa; $b$ ) las sentencias en acciones de responsabilidad en sus diversas variantes: por actividad lícita e ilícita; de carácter contractual y extracontractual; c) las sentencias en materia de empleo público (por ejemplo: reclamos por diferencias salariales); d) sentencias en materia de seguridad social; e) sentencias en los juicios por expropiación.

En segundo lugar están las sentencias que imponen una obligación de hacer. Se trata de decisiones que le imponen al Estado algún tipo de transformación administrativa, que a su vez implica nuevos gastos en recursos humanos, en bienes de diverso tipo o en la construcción de obras de mayor envergadura.

En tercer lugar, en fin, se encuentran las decisiones que anulan un acto administrativo o que invalidan una norma general. Aquí tenemos como forma típica las cuestiones tributarias. Por ejemplo cuando se declara que un tributo ha sido creado violando la reserva de ley, o cuando 
Este libro forma parte del acervo de la Biblioteca Jurídica Virtual del Instituto de Investigaciones Jurídicas de la UNAM

se declara que un tributo actúa de manera irrazonable o confiscatoria. Se ven aquí, a su vez, que hay dos tipos de sentencias: las que tienen efectos generales (por sí mismas o por la inevitable réplica en situaciones análogas) o las que se limitan a un caso en particular.

La incidencia financiera de las decisiones judiciales en materia tributaria ha sido tenido en cuenta en Argentina por su Corte Suprema, al momento de interpretar las condiciones que deben reunirse para dictar una medida cautelar que importe suspender la obligación tributaria. Es decir, si un contribuyente, en juicio, solicita que se suspenda un acto administrativo que impone una obligación de dar una suma de dinero en materia tributaria, el juez debe apreciar la situación con especial rigor dado que está en juego la percepción normal de la renta pública, que es condición de la actuación regular del Estado.

En suma, las finanzas públicas pueden ser afectadas porque los tribunales impongan dar directamente una suma de dinero y el contenido mismo de la sentencia es un gasto público; porque impongan hacer algo que de forma mediata implicará un gasto público o, finalmente, porque la invalidación que disponen implica dejar de recaudar sumas de dinero, reduciéndose así los recursos del Estado. 
Este libro forma parte del acervo de la Biblioteca Jurídica Virtual del Instituto de Investigaciones Jurídicas de la UNAM

\title{
LA GONSTITUCIÓN FINANGIERA MEXICANA Y LOS DEREGHOS HUMANOS
}

\author{
Juan Manuel OrTega MALDONADO* \\ SUMARIO: I. Introducción. II. El Estado financiero mexicano y su nueva \\ Constitución. III. Conclusiones. IV. Bibliografia.
}

\section{INTRODUCGIÓN}

A partir del 2011 la Constitución mexicana tiene un nuevo norte; se ha sustituido el eje sobre la cual gravita. Hoy es el ser humano el centro de todo su entramado, confirmando que la nuestra es, desde aquel año, una Constitución garantista. Si esto es así, como lo deja en claro el propio artículo lo., no debe caber duda que el resto de sus institutos y figuras estarían más en función a este nuevo objetivo que a otros distintos. Para hacer realidad la obligación de promover, respetar, proteger y garantizar los derechos humanos es indispensable contar con recursos públicos. No podemos pasar por alto que no hay derechos humanos sin recursos públicos, y si la obtención y asignación de esos recursos públicos encuentran su regulación básica en la Constitución, entiendo que por esa razón es también una Constitución financiera. Los ingresos y presupuestos públicos encuentran su justificación en tanto que sirven para promover, respetar, proteger y garantizar los derechos humanos. Consecuentemente, los criterios de interpretación de estos institutos financieros deben orientarse también hacia este alto propósito.

* Doctor en derecho por la UNAM; doctor en derecho financiero por la Universidad Complutense de Madrid, maestro en derecho por la UNAM, especialista en derecho fiscal por la UNAM, profesor en la Universidad Autónoma del Estado de Morelos y en la División de Estudios de Posgrado de la Facultad de Derecho de la UNAM, abogado postulante. 
Este libro forma parte del acervo de la Biblioteca Jurídica Virtual del Instituto de Investigaciones Jurídicas de la UNAM

\section{EL ESTADO FINANCIERO MEXICANO Y SU NUEVA Constitución}

Establece el diccionario que por crisis económica debemos entender la reducción en la tasa de crecimiento de la producción de una economía, o la fase más baja de la actividad de un ciclo económico. ${ }^{1}$

De esta definición podemos advertir que una crisis es, por naturaleza, temporal, pasajera, transitoria. Sin embargo, parece ser que en nuestros días y desde hace más de 30 años, la crisis económica es parte de nuestra sociedad. Vive permanentemente con nosotros, colocando los problemas financieros - tanto los relativos a los ingresos como a los gastos públicos - en la mesa de discusión en cualquier ámbito social y a los funcionarios fiscales en el ojo del huracán de todas las frustraciones públicas.

Es un gobierno que ha vivido desde hace algunas décadas en permanente crisis económica, de ahí que el gobierno de la Hacienda Pública se haya convertido en la pieza capital del Estado, en torno al cual giran todas las políticas públicas. ${ }^{2}$

Hemos dicho que el objetivo principal de nuestra Constitución es asegurar los derechos humanos. La Hacienda Pública se muestra como un instrumento decisivo en este sentido porque a través de los recursos públicos se logran satisfacer muchas necesidades colectivas. En la redistribución social el "Estado" y la "economía" parecen fundirse en un mismo punto. El gobierno actual no puede definirse sin acudir a sus "funciones prestacionales". Es, en ese sentido, un Estado social.

Así pues, podemos afirmar que dado que la administración prestacional extrae sus medios económicos gracias a los tributos, Estado de bienestar y Estado financiero se encuentran inseparablemente unidos.

1 Voz "Crisis económica", Diccionario de la Real Academia de la Lengua Española, disponible en: http://dle.rae.es/?id=BHwUydm, consultado el 12 de septiembre de 2016.

2 Un dato interesante del cual poco se ha reflexionado es que los últimos presidentes mexicanos del milenio (José López Portillo, Miguel de la Madrid, Carlos Salinas de Gortari y Ernesto Zedillo Ponce de León) fueron Secretarios de la Hacienda Pública o de Programación y Presupuesto, antes de ser designados presidentes. De hecho, un comentario vertido por el entonces presidente Luis Echeverría Álvarez al abrirse el proceso electoral para designar al nuevo presidente de la República para el periodo 1976-1982, fue que si los problemas de México eran económicos, el presidente debería ser un hacendario, pero si los problemas eran políticos, el presidente debería ser el Secretario de Gobernación. Al final, José López Portillo, entonces Secretario de Hacienda, sería nombrado presidente de México. 
Este libro forma parte del acervo de la Biblioteca Jurídica Virtual del Instituto de Investigaciones Jurídicas de la UNAM

Siguiendo a Barquero Estevan, ${ }^{3}$ debemos subrayar que el Estado, para poder desarrollar sus funciones, está inevitablemente llamado a detraer una parte importante de los ingresos de sus ciudadanos a través de los tributos, y de que, en consecuencia, las del Estado prestacional y las del Estado financiero constituyen "funciones complementarias del Estado social".

Lo que nosotros conocemos como "Estado social" tiene hoy día el rostro de "Estado financiero" en tanto que el instituto tributario y el presupuestario constituyen la base para la realización de los fines del Estado (especialmente los fines económicos y los derechos sociales) no sólo a través de la asignación directa de recursos, sino, también, marcando los derroteros necesarios para la consecución de un orden social más justo. Además, debe también calificarse de "Estado financiero" porque las actividades financieras del Estado forman una parte muy significativa del Producto Interno Bruto.

Ahora, la incapacidad de la Hacienda Pública de allegarse los recursos necesarios para dar cobertura a las necesidades sociales, está sometiendo al Estado a un grado de tensión tal que pone en entredicho su estabilidad y, lo que es aún más grave, la efectividad de los derechos humanos, cuya plasmación a nivel constitucional se había venido postergando desde hace varias décadas.

El artículo 1o. de la Constitución es el parteaguas entre un México retrógrada y una nación soñada por políticos, juristas y organizaciones no gubernamentales deseosos de un país progresista y respetuoso de las libertades públicas.

No obstante, lo que parecía un inicio prometedor pudiera no serlo tanto, dada la crisis económica que aún pervive. Los recientes anuncios de cortes presupuestales ${ }^{4}$ no hacen sino vaticinar peores momentos para metas ya alcanzadas en materia de derechos humanos, lo que debe orillarnos necesariamente a mantener una profunda reflexión jurídica sobre la compatibilidad de los principios que deben regir los recursos públicos ${ }^{5}$ y su trasvase hacia este conjunto de prerrogativas públicas.

3 Barquero Estevan, Juan Manuel, La función del tributo en el Estado social y democrático de Derecho, Madrid, Centro de Estudios Políticos y Constitucionales, 2002, pp. 37 y 38.

4 Entre 2015 y 2016 los recortes al presupuesto de egresos ha sido cercano al $31 \%$ del PIB, más lo que representa el proyecto de presupuesto para 2017. Datos que ofrece la SHCP publicado en el periódico El Universal, disponible en: http://interactivo.eluniversal.com.mx/online/ datos/presupuesto15/.

5 Por ejemplo, nos parece saludable que el principio de proporcionalidad tributaria extienda sus brazos hacia el gasto público, como se expresa en la tesis la. CCXLIX/2007, Semanario Fudicial de la Federación y su Gaceta, Novena Época, t. XXVI, diciembre de 2007, p. 144, cuyo rubro y texto es el siguiente: "PROPORCIONALIDAD TRIBUTARIA. LA PROGRESIVIDAD COMO CRITERIO PROPIO DE DICHO PRINCIPIO GONSTITUCIONAL NO SE LIMITA AL 
Este libro forma parte del acervo de la Biblioteca Jurídica Virtual del Instituto de Investigaciones Jurídicas de la UNAM

Observándolo con objetividad, dudo seriamente que la Constitución pueda preciarse de garantista cuando es desvirtuada por la preminencia de su interpretación economicista para sustentar esos recortes al presupuesto. Estas medidas, en mi opinión, devalúan el contenido normativo de lo que es hoy el centro de la propia Constitución: los derechos humanos. Derechos que parecen estar condicionados o subordinados al imperio de las limitaciones presupuestales.

Resulta paradójico hallarse a medio camino entre un pasado jurisdiccional plagado de trampas procesales ${ }^{6}$ que impedían hacer efectivos muchos derechos sociales y un presente que, si bien empieza a romper con esos viejos moldes, se enfrenta ahora con trampas presupuestales, escondidas bajo la denominación de recortes presupuestales que harán nugatorios muchos derechos fundamentales.

El gasto social, que constituye la viva expresión de un verdadero Estado de derecho, es - a decir de Rodríguez Bereijo — ${ }^{7}$ el "salario social" que garantiza el acceso a determinados bienes públicos que el Estado se compromete a prestar y garantizar. Su perjuicio ya no proviene, como apuntamos líneas atrás, desde el ámbito judicial, sino ahora desde el ejecutivo y legislativo. El problema que apremia la defensa y efectividad de los derechos básicos ya no es cualitativo, sino cuantitativo.

ANÁLISIS DE LA IMPOSICIÓN, SINO QUE TAMBIÉN PUEDE INCLUIR JUICIOS EN TORNO AL REPARTO DIFERENCIADO DEL GASTO PÚBLICO. Algunos sectores de la ciencia económica sostienen que el establecimiento de impuestos progresivos es deseable, pero lo cuestionan como algo complejo; inclusive se ha señalado que la calificación de progresividad no debe formularse considerando exclusivamente el aspecto recaudatorio del fenómeno financiero, sino que también deben valorarse los efectos que corresponden a los sistemas del gasto. En este sentido, en la evaluación de las diferencias que se aprecian en la tributación de los individuos con distintas características puede válidamente involucrarse la diversa distinción derivada de las asignaciones otorgadas a quienes tienen diferentes necesidades, en la parte del fenómeno relacionada con el gasto público. Así, no debe soslayarse que la progresividad del sistema tributario y su intrínseca justicia pueden garantizarse si éste resulta coherente e integrado con el gasto público, que debe dirigirse a satisfacer las prioridades que le asigna la Constitución Política de los Estados Unidos Mexicanos, tendente a lograr una igualdad de hecho. En tal virtud, la desigualdad cualitativa indispensable para cumplir con el principio constitucional de proporcionalidad tributaria, es la que se realiza mediante la progresividad global del sistema fiscal en que se alienta la aspiración a la redistribución de la renta, propósito que puede conseguirse a través de la tributación diferenciada, y también mediante el reparto diferenciado del gasto público, atendiendo a las necesidades sociales que el texto constitucional reconozca".

6 Nos referimos, entre otros, a los conceptos de "interés jurídico", "estricto derecho", "principio de definitividad", etcétera, que hacían tortuosos los senderos jurisdiccionales.

7 Rodríguez Bereijo, Álvaro, La Constitución fiscal de España, Madrid, Centro de Estudios Políticos y Constitucionales, 2015, p. 15. 
Este libro forma parte del acervo de la Biblioteca Jurídica Virtual del Instituto de Investigaciones Jurídicas de la UNAM

La necesaria reducción de los derechos públicos subjetivos no se producirá de forma abierta, como otrora venía sucediendo, sino en forma indirecta, bien a través de su inaplicación, o bien, vía política presupuestaria de gasto público, lo que augura que muchos de esos derechos devengan en "derechos programáticos" como los calificara en su oportunidad el maestro Ignacio Burgoa. ${ }^{8}$

Como hemos adelantado, se trata de un problema que incide en los dos principales brazos del derecho financiero: el ingreso y el gasto.

Lo primero porque debemos cuestionarnos (otra vez) sobre la justicia en el reparto de la carga tributaria, sometiendo a un nuevo juicio los principios tradicionales del derecho fiscal, como la capacidad contributiva, la progresividad, la equidad y un puñado más de principios fundacionales de esta materia. Y, por otro lado, sobre las políticas de gasto público, que deben estar enfocadas básicamente en la distribución equitativa de los sacrificios comunales, que deberían servir para hacer frente a una enorme desigualdad social, ${ }^{9}$ producto de las crisis económicas (más preciso de la crisis económica que no hemos dejado) y de la globalización de la economía.

La reforma constitucional al artículo 1o. catapultó los derechos humanos hacia la cúspide del ordenamiento jurídico nacional. Bajo esta premisa, se debe cuestionar en qué medida las restricciones presupuestales pueden determinar el contenido normativo de todo ese conjunto de derechos y si las condiciones económicas o presupuestales representan, en cada caso, la concreta medida del contenido de nuestras libertades fundamentales.

Tal vez una pregunta deje más claro el tema: ¿Los derechos humanos que se establecen en la Constitución deben reconocerse sólo en la medida de la capacidad financiera del Estado o, por el contrario, el Estado debe ofrecer y garantizar esas prestaciones en la medida en que se reconocen esos derechos básicos? La respuesta, como el problema mismo, es muy compleja.

En una interesante obra, Holmes y Sunstein ${ }^{10}$ confirman lo que todos sospechábamos pero que nos negábamos a admitir abiertamente:

8 Burgoa Orihuela, Ignacio, Las garantías individuales, México, Porrúa, 1990, pp. 135 y ss.

9 México, según el coeficiente Gini, contenido en el Informe sobre Desarrollo Humano dado a conocer por la ONU en 2012, era de los más altos de Latinoamérica, con un 48.1, cuando rebasar los 4.0 es ya alarmante por la grave tensión social que esto puede originar, datos disponibles en: http://datos.bancomundial.org/indicador/SI.POV.GINI:locations $=M X$.

10 Holmes, Stephen y Sunstein, Cass, El costo de los derechos. Por qué la libertad depende de los impuestos, Argentina, Siglo XXI, 2012. 
Este libro forma parte del acervo de la Biblioteca Jurídica Virtual del Instituto de Investigaciones Jurídicas de la UNAM

todos los derechos humanos, incluso los derechos individuales, tienen un costo. Sostienen que no hay derechos humanos sin impuestos, dado que todos esos derechos requieren, para su realización y efectividad, de recursos públicos.

A esta afirmación debe adicionarse el hecho de que si esos recursos son escasos y susceptibles de empleos alternativos, las posibilidades del Estado financiero es un elemento que juega en la respuesta que había planteado líneas atrás.

Es evidente que no existen derechos absolutos o sin coste, de tal forma que la decisión de qué derechos se garantizarán y en qué medida es una decisión que se mantiene en el ámbito político y que está condicionada por la capacidad financiera del Estado en determinado momento, de las diferentes opciones políticas del gobierno y de la definición de cuáles serán sus prioridades o preferencias.

El tema de lo "financieramente posible" ha estado presente en la jurisprudencia constitucional mexicana, tanto en aquellos casos tradicionales en los que se exigen presupuestos públicos suficientes para dar cumplimiento a las sentencias de amparo, ${ }^{11}$ como especialmente en aquellos que atañen a la defensa de derechos sociales, pues resulta un medio idóneo para concretizar esos derechos sociales de contenido prestacional.

Debe subrayarse incluso que en el primer grupo de asuntos, es decir, aquellos en los que los tribunales han exigido el cumplimiento de las sentencias de amparo vía la ampliación de presupuestos públicos, se ha destacado que los recursos públicos deben realizarse con un enfoque de respeto a los

11 Sobre el particular, pueden consultarse las tesis jurisprudencialess P./J. 7/2011, P./J. 8/2011 y P./J 9/2011, que aparecen publicadas en el Semanario fudicial de la Federación y su Gaceta, Novena Época, t. XXXIII, marzo de 2011, pp. 5, 6 y 8, respectivamente, cuyos sendos rubros son los que a continuación se citan: "SENTENCIAS DE AMPARO GUYO CUMPLIMIENTO IMPLICA UN PAGO A CARGO DE AUTORIDADES DEL GOBIERNO DEL DISTRITO

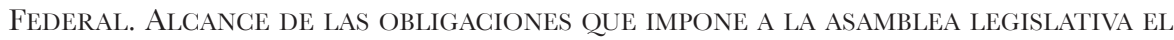
PÁRRAFO PRIMERO DEL ARTíCULO 73 DE LA LEY DE PRESUPUESTO Y GASTO EFICIENTE DE ESA ENTIDAD”; "SENTENGIAS DE AMPARO CUYO CUMPLIMIENTO IMPLICA UN PAGO A CARGO DE AUTORIDADES DEL GOBIERNO DEL DiSTRITO FEDERAL. El PÁRRAFO SEGUNDO

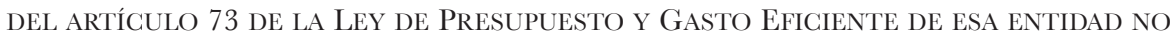
IMPIDE A ÉSTAS, EN EL ÁMBITO DE SU COMPETENCIA, REALIZAR ADECUACIONES PRESUPUESTALES PARA CUMPLIR GON AQUELLAS GUANDO SE AGOTE LA PARTIDA PRESUPUESTAL AUTORIZADA PARA TAL EFECTO POR LA ASAMBLEA LEGISLATIVA DEL DISTRITO FEDERAL"; "SENTENCIAS DE AMPARO GUYO CUMPLIMIENTO IMPLICA PAGOS A CARGO DE LAS AUTORIDADES DEL GOBIERNO DEL DISTRITO FEDERAL. AL CONSTITUIR PRESUPUESTO DEVENGADO, SU MONTO DEBE INCLUIRSE CON PREGISIÓN EN EL ANTEPROYECTO, PROGRAMARSE EN EL PROYECTO Y APROBARSE EN EL PRESUPUESTO DE EGRESOS”. 
Este libro forma parte del acervo de la Biblioteca Jurídica Virtual del Instituto de Investigaciones Jurídicas de la UNAM

derechos humanos, entre otros principios, lo que también ha sido materia de regulación en algunos ordenamientos presupuestarios. ${ }^{12}$

Pero - es necesario destacarlo - la Constitución no otorga al legislador que aprueba el presupuesto un cheque en blanco para disponer en forma discrecional la realización o no de ese cúmulo de derechos.

Lo que la carta magna sí exige expresamente es una vinculación positiva de "todas las autoridades para promover, respetar, proteger y garantizar los derechos humanos", incluyendo aquellas responsables de la proposición y aprobación de los tributos y presupuestos públicos.

Esta postura ha sido asumida por distintos tribunales al resolver casos en los que se ha planteado la violación a un derecho fundamental por insuficiencia de recursos públicos. El derecho humano a la salud, a una administración de justicia pronta y expedita o el derecho a la educación han sido parte de este grupo de asuntos.

Incluso antes de la reforma constitucional de junio de 2011, la SCJN había entendido que los presupuestos insuficientes no podían constituir un valladar para la vulneración a un derecho fundamental. Así lo dejó establecido respecto al derecho a la salud, ${ }^{13}$ al derecho a una administración de justicia pronta y expedita ${ }^{14}$ o el derecho a la educación. ${ }^{15}$

Ahora bien, la idea de una Constitución financiera, es decir, de una Constitución cuyos institutos tributarios y presupuestarios se estructuran y proyectan para la promoción, respeto, protección y garantía de los derechos humanos, no puede cerrarse sin un método de interpretación que logre este cometido. Es por eso que nos ocuparemos ahora de reflexionar sobre este aspecto.

Entiendo que la interpretación que debe hacerse es de las normas relativas a los derechos humanos que se vean afectado por las reglas tributarias o presupuestarias.

12 El artículo 1o. de la Ley de Presupuesto y Gasto Eficiente del Distrito Federal reza en el tercer párrafo lo siguiente: "Los sujetos obligados a cumplir las disposiciones de esta Ley deberán observar que la administración de los recursos públicos se realice con base en criterios de legalidad, honestidad, austeridad, eficiencia, eficacia, economía, racionalidad, resultados, transparencia, control, rendición de cuentas, con una perspectiva que fomente la equidad de género y con un enfoque de respeto a los derechos humanos".

13 Tesis P. XVI/2011, Semanario Fudicial de la Federación y su Gaceta, Novena Época, agosto de 2011 , p. 29.

14 Tesis II.1o.T.6 L, Semanario fudicial de la Federación y su Gaceta, Décima Época, t. 2, Libro XVII, febrero de 2013, p. 1301.

15 Tesis 1a. CLXXVIII/2015, Gaceta del Semanario fudicial de la Federación, Décima Época, t. I, libro 18, mayo de 2015, p. 427. 
Este libro forma parte del acervo de la Biblioteca Jurídica Virtual del Instituto de Investigaciones Jurídicas de la UNAM

La tarea no resulta complicada, dado que la propia Norma Suprema nos ofrece estas pautas en el propio artículo lo., párrafos segundo y tercero, al indicar:

Las normas relativas a los derechos humanos se interpretarán de conformidad con esta Constitución y con los tratados internacionales de la materia favoreciendo en todo tiempo a las personas la protección más amplia”.

Todas las autoridades, en el ámbito de sus competencias, tienen la obligación de promover, respetar, proteger y garantizar los derechos humanos de conformidad con los principios de universalidad, interdependencia, indivisibilidad y progresividad. En consecuencia, el Estado deberá prevenir, investigar, sancionar y reparar las violaciones a los derechos humanos, en los términos que establezca la ley.

Por lo que hace a la "interpretación conforme" y al principio pro persona, los tribunales han marcado una línea jurisprudencial que inicia primero con una aproximación al concepto ${ }^{16}$ y después con identificar su naturaleza y alcance. ${ }^{17}$

Respecto a los principios de optimización interpretativa de los derechos humanos, es decir, la universalidad, interdependencia, indivisibilidad y progresividad, los tribunales han iniciado este proceso clarificando su contenido y alcance. ${ }^{18}$ Un poco más tarde, y dando continuidad al anterior criterio, se logra su definición. ${ }^{19}$ Meses después se continuó abonando en el sentido de perfilar los contornos de estos conceptos. ${ }^{20}$ Los últimos pronunciamientos de esta línea jurisprudencial son aquéllos que enuncian los criterios para determinar si la limitación al ejercicio de un derecho humano deriva en la violación del principio de progresividad y que determinan su naturaleza y función en el Estado mexicano. ${ }^{21}$

16 Tesis la. CCXIV/2013, Semanario Fudicial de la Federación y su Gaceta, Décima Época, t. 1, libro XXII, julio de 2013, p. 556.

17 Tesis 1a. CCCXL/2013, Gaceta del Semanario Fudicial de la Federación, Décima Época, t. I, libro 1, diciembre de 2013, p. 530.

18 Tesis III.4o. (III Región) 4 K, Semanario Fudicial de la Federación y su Gaceta, Décima Época, t. 5, libro IV, enero de 2012, p. 4580.

19 Tesis IV.2o.A.15 K, Semanario Fudicial de la Federación y su Gaceta, Décima Época, t. 3, libro XII, septiembre de 2012, p. 1946.

20 Tesis I.4o.A.9 K, Semanario fudicial de la Federación y su Gaceta, Décima Época, t. 3, libro XIX, abril de 2013, p. 2254.

21 Tesis 2a. CXXVI/2015, Gaceta del Semanario Fudicial de la Federación, Décima Época, t. II, libro 24, noviembre de 2015, p. 1298, y Tesis 2a. CXXVII/2015, Gaceta del Semanario Fudicial de la Federación, Décima Época, t. II, libro 24, noviembre de 2015, p. 1298. 
Este libro forma parte del acervo de la Biblioteca Jurídica Virtual del Instituto de Investigaciones Jurídicas de la UNAM

De todos los criterios antes referidos, podemos observar un intento no sólo para definir esos elementos interpretativos, sino también para destacar sus virtudes y potenciar sus alcances.

Concretamente, en materia financiera (tributaria y presupuestaria) esta interpretación debe ajustarse también a esos criterios en prácticamente todo momento, pues los presupuestos públicos están diseñados para cumplir con el proyecto constitucional que es, básicamente, el promover, respetar, proteger y garantizar los derechos humanos.

En ese sentido parecen empezar a moverse algunos tribunales:

a) Un asunto interesante es conocido como "Mini Numa". Esta población se halla en el municipio de Metlatónoc, Estado de Guerrero, ahí reside la comunidad $\mathcal{N a}$ Savi que carecía de un centro de salud que atendiera sus necesidades y como consecuencia, las muertes derivadas de la pobreza eran muy frecuentes entre niños y mujeres. ${ }^{22}$ La comunidad hizo saber a diversas instancias gubernamentales, y en diversos momentos, esta situación que no fue debidamente atendida, por lo que acudió ante la Comisión Estatal de Derechos Humanos, la cual emitió una recomendación contra las autoridades estatales. Desafortunadamente éstas poco hicieron y ello abrió la posibilidad de promover el juicio de amparo bajo el argumento de violación al derecho a la salud consagrado en el artículo 4o. constitucional. El Juez dictó sentencia otorgando el amparo y protección de la justicia federal a la comunidad, condenando a las autoridades a ofrecer los servicios demandados, con la advertencia de que no podrían aducir "falta de recursos públicos" para eludir el cumplimiento de lo ordenado. ${ }^{23}$

b) El otro asunto es conocido como "Pabellón 13" y los hechos son los siguientes: al Instituto Nacional de Enfermedades Respiratorias, ubicado en el Distrito Federal, se les autorizó un presupuesto para remodelar y equipar el servicio clínico número 4 y atender en mejores condiciones a pacientes con VIH. El propio Instituto prefirió sustituir esta remodelación por la construcción de un nuevo espacio, denominado "Pabellón 13". Por varias razones administrativas esta construcción no se realizó durante varios años y por eso diversos

22 Es decir, enfermedades como la diarrea y la neumonía, que suelen ser un pequeño malestar en otros países, se convierten en enemigos invencibles en países "en desarrollo" como el nuestro.

23 Sentencia de juicio de amparo 1157/2007-II emitida por el Séptimo Juzgado de Distrito en el Estado de Guerrero, de 11 de julio de 2008. 
Este libro forma parte del acervo de la Biblioteca Jurídica Virtual del Instituto de Investigaciones Jurídicas de la UNAM

pacientes promovieron demanda de amparo por considerar violados los artículo 1o., 4o., 14 y 16 de la Constitución.

En primera instancia, e incluso mediante recurso de revisión, se negó la concesión del amparo, pero al llegar a la Suprema Corte de Justicia de la Nación ésta redefinió la litis y advirtió la necesidad de proporcionar recursos económicos suficientes, y en base a la existencia del derecho internacional, justificó el control judicial de la políticas públicas y ordenó al Instituto, en coordinación con el Comisionado Nacional de Protección Social en Salud, adoptar las medidas necesarias para el uso máximo de los recursos económicos para proteger el derecho a la salud, advirtiendo lo injustificado que sería que las responsables adujeran limitación de recursos económicos. ${ }^{24}$

Así pues, para resolver la problemática antes descrita que enfrentan las autoridades del Estado (órganos de gobierno y tribunales del poder judicial), se propone como solución privilegiar un criterio finalista al interpretar y aplicar los institutos financieros (tributos y presupuestos públicos), lo que resultará más acorde con nuestro nuevo marco constitucional (artículo lo.), y que conlleva el reconocimiento de una Constitución financiera.

\section{CONCLUSIONES}

1. Dado que la administración prestacional extrae sus medios económicos gracias a los tributos, Estado de bienestar y Estado financiero se encuentran inseparablemente unidos.

2. En nuestros días los derechos humanos parecen estar condicionados o subordinados al imperio de las limitaciones presupuestales; a nuevas trampas presupuestales, escondidas bajo la denominación de recortes presupuestales.

3. El gasto social, que hoy día debe calificarse de un salario social, tienen sus mayores embates desde la perspectiva cuantitativa, que amenaza con convertirlos en derechos programáticos otra vez.

4. La carta magna exige expresamente una vinculación positiva de "todas las autoridades para promover, respetar, proteger y garantizar los derechos humanos", incluyendo aquellas responsables de la proposición y aprobación de los tributos y presupuestos públicos.

24 Véase la sentencia recaída del amparo en revisión 378/2014, Segunda Sala de la Suprema Corte de Justicia de la Nación. 
Este libro forma parte del acervo de la Biblioteca Jurídica Virtual del Instituto de Investigaciones Jurídicas de la UNAM

5. Tenemos una Constitución financiera, es decir, una Constitución cuyos institutos tributarios y presupuestarios se estructuran y proyectan para la promoción, respeto, protección y garantía de los derechos humanos.

6. Si los presupuestos públicos están diseñados para cumplir con el proyecto constitucional que es, básicamente, el promover, respetar, proteger y garantizar los derechos humanos, entonces sus criterios de interpretación y aplicación deben ser los que se indican en el artículo 1o. constitucional.

\section{BIBLIOGRAFÍA}

Barquero Estevan, Juan Manuel, La función del tributo en el Estado social y democrático de derecho, Madrid, Centro de Estudios Políticos y Constitucionales, 2002.

Burgoa Orihuela, Ignacio, Las garantías individuales, México, Porrúa, 1990.

Holmes, Stephen y Sunstein, Cass, El costo de los derechos. Por qué la libertad depende de los impuestos, Argentina, Siglo XXI, 2012.

Real AGademia Española, Diccionario de la Lengua Española, disponible en: http: //dle.rae.es $/$ ? $i d=B H w U y d m$.

Rodríguez Bereijo, Álvaro, La Constitución Fiscal de España, Madrid, Centro de Estudios Políticos y Constitucionales, 2015. 
Este libro forma parte del acervo de la Biblioteca Jurídica Virtual del Instituto de Investigaciones Jurídicas de la UNAM

\title{
LOS DERECHOS HUMANOS EN EL CICLO PRESUPUESTARIO
}

\author{
Óscar NAVA EsGUDERO*
}

\begin{abstract}
SUMARIO: I. Introducción. II. La participación ciudadana como mecanismo garante del cuidado y respeto de los derechos humanos en el ciclo presupuestario. III. Planeación. IV. Elaboración. V. Ejecución. VI. Control. VII. Conclusión. VIII. Bibliografia.
\end{abstract}

\section{INTRODUCCIÓN}

El presente trabajo se enfoca en revisar el impacto que tiene la exigibilidad de los derechos humanos en el ciclo presupuestario, entendido este último como el conjunto de etapas o fases mediante las cuales se planean, autorizan, erogan y se controlan los recursos públicos o el presupuesto del estado, a saber: planeación, elaboración, aprobación, ejecución y control.

En este contexto adquiere relevancia entender la interdependencia que tienen los derechos humanos y el presupuesto público, y a la vez, la importancia de la participación ciudadana en la exigibilidad de los mismos. Es el propio ciudadano quien finalmente sufre una violación a sus derechos y busca o exige alguna vía para hacerlos valer y defenderlos; en consecuencia, paralelamente a los mecanismos judiciales que ya existen y que en buena medida han demostrado su insuficiencia en esta materia habida cuenta de diferentes circunstancias (procedimientos largos y tediosos, corrupción de servidores públicos a mansalva, falta de dinero público, etcétera) la participación ciudadana, hoy en día en casi todos los países del mundo, se ha vuelto el mecanismo más a la mano para defenderlos.

Si bien los derechos humanos se encuentran tutelados por nuestra Constitución Política, la protección y el ejercicio de aquéllos, en casi la

* Doctor en derecho financiero y tributario, con especialidad en derecho presupuestario, por la Universidad Complutense de Madrid, España. Asesor jurídico en materia de presupuesto y gasto público. 
Este libro forma parte del acervo de la Biblioteca Jurídica Virtual del Instituto de Investigaciones Jurídicas de la UNAM

totalidad de las ocasiones requieren de recursos públicos del Estado para entenderlos atendidos. ¿Cómo entender nuestro derecho a la salud, si el Estado no se ocupa de comprar medicinas o de construir hospitales?, ¿cómo tener por satisfecho nuestro derecho a un debido proceso, si el aparato gubernamental no contempla recursos públicos para establecer tribunales al efecto?, ¿cómo entender el derecho a una justicia pronta y expedita protegido por el artículo 17 de nuestra carta federal, si el gobierno no mejora la calidad de la impartición de justicia? Si un juez condena al Estado al pago de una suma de dinero para atender el derecho que tiene un enfermo terminal a tener unas instalaciones adecuadas o a recibir una muerte asistida, ¿cómo entender que el Estado se niegue a atender ese derecho alegando la falta de dinero público o la falta de partida presupuestaria? En fin, cómo exigir, proteger, ejercer nuestros derechos si el Estado no dispone dinero público para tal efecto, o peor aún, habiéndolo se niega a otorgarlo a ese fin.

Es por ello también la participación ciudadana es piedra angular en la exigibilidad de sus (de nuestros) derechos, y no solamente cuando el ciudadano se ve afectado en alguno de ellos, sino, de igual manera, durante todo el ciclo presupuestario: en la planeación, cuando se proyecta el plan económico del Estado; en la elaboración del presupuesto, cuando se confeccionan los anteproyectos de presupuestos de los entes públicos; en la aprobación, a través de la representación de diputados; en el ejercicio fiscal, mediante denuncias ciudadanas, entre otros medios de participación y observación; y en el control del gasto público, cuando se fiscalizan las cuentas públicas presentadas por el gobierno al órgano de control externo.

En México, la participación ciudadana en el ciclo presupuestario para la defensa de los derechos humanos ha ido in crescendo con grandes esfuerzos y entronados debates sociales, políticos y académicos, a través de la transparencia gubernamental, de la denuncia, de los presupuestos participativos, etcétera, pero se tiene la sensación de que no ha sido suficiente, porque una vez dada la transparencia o realizada la denuncia, los procedimientos para obligar al Estado a cumplir sus compromisos no son vinculantes, sobre todo en materia presupuestaria, en donde conseguir un peso para atender la violación de un derecho humano supone para el ciudadano un verdadero vía crucis. Se ha hecho mucho, sobre todo a partir de la reforma constitucional en materia de derechos humanos publicada en el Diario Oficial de la Federación (DOF) el 10 de junio de 2011, pero actualmente la legislación en materia presupuestaria y de control del gasto público, ralentiza el estado ideal de respeto, cuidado y atención de los derechos humanos. 
Este libro forma parte del acervo de la Biblioteca Jurídica Virtual del Instituto de Investigaciones Jurídicas de la UNAM

\section{LA PARTICIPACIÓN GIUDADANA COMO MEGANISMO GARANTE DEL CUIDADO Y RESPETO DE LOS DERECHOS HUMANOS EN EL CICLO PRESUPUESTARIO}

\section{Los orígenes de la participación ciudadana en la confección del presupuesto público}

Si es tarea de difícil desempeño y estudio fijar la fecha y el lugar del primer Presupuesto Público, más complicado resulta determinar a partir de qué momento los ciudadanos participaron de la elaboración, ejercicio y control del presupuesto. Aunque cabe entender que fue a partir de la creación de las Asambleas Legislativas, como un medio de control al rey o monarca al momento de fijar los impuestos y gastos, cuando el pueblo, a través de su consentimiento y autorización, empezó a intervenir en los asuntos económicos del Estado. Pero la participación del ciudadano en los asuntos públicos tiene un origen más remoto: la Grecia antigua.

Habrá que convenir, junto a Chalfoun Blanco, ${ }^{1}$ la diferencia entre la ciudadanía ateniense y la ciudadanía romana; en la primera se definía como una facultad de participar en la comunidad, mientras que los romanos la ligaban a una institución jurídica en la que no había derecho de participación. Con el Estado moderno se dio una tendencia a aceptar la concepción romana del término, esto es, el ciudadano como una persona sujeta a derechos en el terreno familiar, económico, judicial, religioso, aparte de su estatus político. Es a partir de las revoluciones liberales de los siglos XVIII y XIX cuando se retoma el modelo ateniense y se consolida el humanismo clásico.

El impulso de la creación de las asambleas legislativas como respuesta al gasto descontrolado de los gobiernos que buscan la protección de los intereses ciudadanos frente a los excesos de los reyes, obligó a dichos gobiernos a constituir documentos que debían prever con antelación los gastos anuales, estableciendo las prioridades gubernamentales y asegurándose con tal previsión que el gasto total no excediera los recursos disponibles; pero además facilitó la instauración de medios para controlar las finanzas del gobierno. Estos documentos se consolidaron en lo que ahora conocemos como presupuestos. Surgen con ello los principios presupuestarios clásicos, como principios jurídicos, contables, económicos, reguladores del ciclo presupuestario y cuyo principal objetivo era el de regular la gestión financiera del gobierno.

1 Citada por Vacas García-Alós, Luis, Ética pública y participación ciudadana en el control de las cuentas públicas, España, REUS, 2015, pp. 151 y 152. 
Este libro forma parte del acervo de la Biblioteca Jurídica Virtual del Instituto de Investigaciones Jurídicas de la UNAM

Los principios presupuestarios, como dice Allen Shick, contribuyeron en gran medida a democratizar el procedimiento presupuestario porque

...dieron a los ciudadanos transparencia... mediante una lista específica de gasto antes de que el Gobierno lo realizara, haciendo posible de esta manera que la asamblea legislativa pudiera denegar la autorización para gastar y estableciera las bases tanto para controlar las cantidades gastadas como para hacer a los que gastaban responsables de sus acciones. ${ }^{2}$

Actualmente, la Unión Europea busca potenciar la participación ciudadana a fin de llegar a la noción de "ciudadano de pleno derecho a la vez que participativo, conviviendo en una comunidad donde a los propios ciudadanos se les reconocen los derechos civiles, políticos, económicos y culturales" de manera que "la condición de ciudadano implica una obligación participativa, que no viola su derecho individual, sino que lo amplía al hacerle responsable de la construcción de una sociedad más democrática, fundamento de la concepción griega del ciudadano". ${ }^{3}$

\section{Breve análisis sobre el proceso histórico de la participación ciudadana en México}

México ha vivido un proceso muy lento en cuanto a participación ciudadana en la vida pública y/o en las decisiones políticas y económicas del país. Términos como "referéndum", "consulta ciudadana", "consulta pública", "denuncia pública", si bien estaban previstos algunos de ellos en la Constitución Política de los Estados Unidos Mexicanos (CPEUM), y otros en la legislación secundaria, no se usaban, bien porque no estaban reglamentados o bien porque el procedimiento no era claro o de muy difícil cumplimiento. A esta dificultad habría que agregarle otra muy importante que también impactó en la participación ciudadana en temas de gasto público y de control del mismo: durante casi 70 años el signo político de la mayoría en la Cámara de Diputados era el mismo que el del presidente de la República. Por tanto, la discusión del proyecto de Presupuesto de Egresos de la Federación presentado por el Ejecutivo federal a la cámara baja durante todo ese tiempo no sufrió ninguna modificación y si la hubo era convenida; acaso algún comentario de algún diputado a fin al partido sólo para confirmar lo propuesto por el presidente en turno. Por supues-

2 Allen, Schick, "Redemocratizar los presupuestos", Los presupuestos del Estado: transparencia y democracia, España, Fundación Modernización de España, 2003, p. 22.

3 Chalfoun Blanco, M. E., citada por Vacas García-Alós, Luis, op. cit., p. 152. 
Este libro forma parte del acervo de la Biblioteca Jurídica Virtual del Instituto de Investigaciones Jurídicas de la UNAM

to, al existir mayoría de diputados del PRI, las modificaciones propuestas por los partidos de oposición eran ignoradas. Este aspecto político-jurídico, fundamental en nuestra vida constitucional, marcó un antes y un después del derecho presupuestario, y en consecuencia de la participación ciudadana a través de sus representantes ante el Congreso de la Unión. Bajo este esquema huelga decir que se dedicaban muy pocos recursos a los escasos mecanismos de participación y menos aún a la atención de los derechos reclamados por los ciudadanos.

Con la elecciones intermedias de 1997, este esquema se empieza a transformar habida cuenta de que el partido en el poder ya no cuenta con mayoría parlamentaria, por lo que las voces de los ciudadanos a través de los diputados se empiezan a oír y esto cambia el panorama de la participación de la población en los asuntos económicos de México. No obstante este proceso que se reafirmó en las elecciones del año 2000, los criterios de la Suprema Corte de Justicia de la Nación en la Acción de Inconstitucionalidad 4/1998 y en la Controversia Constitucional 109/2004, lamentables - a mi parecer-, retrasan el proceso de la construcción del emergente derecho presupuestario y de la atención de los derechos humanos con recursos públicos. El cercenamiento de las facultades constitucional/presupuestarias de la Cámara de Diputados, por mor de estos criterios judiciales, impiden la democratización del presupuesto y por el contrario se siguen razonamientos de hace más de 170 años, creados en el autoritario, antidemocrático y antiparlamentario periodo de la Prusia de Guillermo I y de su astuto canciller Bismarck, conocido como el Canciller de Hierro.

Actualmente nuestra Constitución cuenta con mayores mecanismos de participación ciudadana que garantizan de alguna forma la protección de los derechos humanos contemplados en la misma: la participación ciudadana para el acceso y uso equitativo y sustentable de los recursos hídricos (derecho al agua, artículo 4o.); derecho de petición en el artículo 8o. constitucional; la consulta popular en ocasión de la elaboración del Plan Nacional de Desarrollo (artículo 26); iniciativa de ley ciudadana en la fracción IV del artículo 71 (cuyo ejemplo paradigmático es la Ley 3 de 3); el derecho de los pueblos indígenas para auto determinarse (artículo 2o.); la transparencia gubernamental (artículo 6o.); la denuncia por malversación de fondos públicos (artículo 79, fracción I); la consulta ciudadana para nombrar a los comisionados del INAI (artículo 6o., fracción VII); el derecho a votar en las consultas populares (artículo 35, fracción VIII); la votación para nombrar al presidente de la Comisión Nacional de los Derechos Humanos (artículo 102, apartado B); la participación ciudadana y vecinal en los municipios (artículo 115, fracción II); la creación de un 
Este libro forma parte del acervo de la Biblioteca Jurídica Virtual del Instituto de Investigaciones Jurídicas de la UNAM

Comité de Participación Ciudadana Dentro del Sistema Nacional Anticorrupción (artículo 113).

Con la reforma al artículo 1o., constitucional en materia de derechos humanos, publicada en el $D O F$ el 10 de junio 2011, sobre todo en el párrafo tercero, se establece una obligación ineludible para el Estado:

Todas las autoridades, en el ámbito de sus competencias, tienen la obligación de promover, respetar, proteger y garantizar los derechos humanos de conformidad con los principios de universalidad, interdependencia, indivisibilidad y progresividad. En consecuencia, el Estado deberá prevenir, investigar, sancionar y reparar las violaciones a los derechos humanos, en los términos que establezca la ley.

Y esta obligación implica para el Estado el destinar recursos públicos, a través del presupuesto, para su acatamiento. De aquí que exista una relación íntima entre la exigibilidad de los derechos humanos y la dotación de fondos presupuestarios para atenderlos. La conformación del gasto público ya no sólo es consecuencia de la existencia de necesidades públicas del Estado, pues dependerá del gobierno que se instale la priorización de unas y otras, sino de su integración tomando en cuenta las instituciones constitucionales en las que se incluye al bien común como valor ${ }^{4}$ y que por lo mismo no se encuentra sujeta a los vaivenes políticos de cambio de gobierno y del pensamiento político en turno. Y en esta nueva concepción de la actividad financiera del Estado, se instala con mayor comodidad y certidumbre jurídica el respeto y cuidado de los derechos humanos.

Es entonces cuando se torna necesario buscar en el ciclo presupuestario, cómo es que el Estado va a garantizar los derechos de los ciudadanos. Y esto conlleva a conocer cuáles son los mecanismos para exigir el cuidado y respeto o reparación de la violación de los derechos humanos.

\section{PlaneAción}

La planeación del gasto público se realiza año con año antes de confeccionar los anteproyectos de presupuesto de los entes públicos mediante los programas anuales que incluyen los aspectos administrativos y de política económica, social, ambiental y cultural, pero siempre con sustento en la planeación

4 Para mayor abundamiento, véase este quiebro conceptual de la actividad financiera del Estado, en Corti, Horacio, Derecho constitucional presupuestario, 2a. ed., Buenos Aires, Abeledo-Perrot, 2011, p. 12. 
Este libro forma parte del acervo de la Biblioteca Jurídica Virtual del Instituto de Investigaciones Jurídicas de la UNAM

sexenal que realiza el presidente de la República cada seis años, a través del Plan Nacional de Desarrollo.

El vigente Plan Nacional de Desarrollo 2013-2018, se publicó en el $D O F$ el 20 de mayo de 2013, en cumplimiento del artículo 21 de la Ley de Planeación que establece que éste deberá elaborarse, aprobarse y publicarse dentro de un plazo de seis meses contados a partir de la fecha en que toma posesión el presidente de la República.

Para la elaboración del Plan intervienen el Congreso de la Unión, las dependencias y entidades de la administración pública federal, la Ciudad de México (otrora Distrito Federal), las entidades federativas y los municipios, pero también los actores políticos, sociales y culturales según establece el artículo 26, apartado A de la CPEUM. ¿En qué consiste esta participación y cómo se lleva a cabo?

La participación de dicho sector tiene el propósito de que la población exprese sus opiniones para la elaboración, actualización y ejecución del Plan y los programas. Las opiniones de la población se hacen mediante dos vías: 1) a través de una consulta por Internet previa a la elaboración del Plan, a efecto de que el presidente tome en cuenta dicha participación, y 2) mediante foros de consulta popular que se convoquen, y que servirán como órganos de consulta permanente, en los cuales participarán las organizaciones representativas de los obreros, campesinos, pueblos y grupos populares; de las instituciones académicas, profesionales y de investigación de los organismos empresariales; y de otras agrupaciones sociales (artículo 20 Ley de Planeación). Se entiende por tanto, que hay una participación previa de la ciudadanía al momento de confeccionar el Plan y una participación de tracto sucesivo, que podrá darse durante el correspondiente ejercicio fiscal y durante la vigencia del Plan y de sus programas a efecto de, inclusive, modificarlos.

Ahora bien, habrá que analizar la vinculación de dicha participación, tanto en el Plan como en los programas gubernamentales.

En cuanto a la participación ciudadana en el Plan, ${ }^{5}$ las opiniones de la población no obligan a ser consideradas por el presidente de la República

5 El resultado oficial de la participación ciudadana fue el siguiente: “....se puso a disposición de la ciudadanía la página de internet pnd.gob.mx, para la recepción de propuestas en archivos digitales y a través de la cual se realizaron encuestas interactivas. De manera paralela, se abrieron ventanillas de recepción física de propuestas en toda la República Mexicana. Adicionalmente, se llevaron a cabo 397 acciones de consulta, incluyendo la realización de 5 Foros Nacionales con 31 páneles de discusión, 7 Foros Especiales con 40 páneles de discusión, 32 Foros Estatales con 160 páneles de discusión y 122 Mesas Sectoriales con especialistas y diversos grupos de interés. A través de estos medios hubo en total 228,949 participa- 
Este libro forma parte del acervo de la Biblioteca Jurídica Virtual del Instituto de Investigaciones Jurídicas de la UNAM

en la elaboración del Plan. Puede tomarlas en cuenta, e inclusive le pueden aportar ideas o acciones que aquel no tenía contempladas, pero también puede desecharlas de plano. La contundencia de esta afirmación que descuartiza las intenciones democráticas de la participación ciudadana en la planeación económica gubernamental, deviene de dos aspectos, uno jurídico y otro práctico.

Jurídico, porque el Plan es un mero acto administrativo cuyos efectos jurídicos sólo son vinculantes para las dependencias del Ejecutivo federal, y acaso como guía para las entidades paraestatales, pero nunca para el resto de los entes públicos (que idealmente pueden seguir la directriz del mismo), y menos para población en general. La opinión de la población no es obligatoria para la elaboración del Plan y una vez publicado éste en el $D O F$ tampoco vincula a la ciudadanía, por tanto, la participación ciudadana en este aspecto jurídico es inoperante. Es cierto que previo a la publicación oficial del Plan, se remite al Congreso de la Unión, pero sólo para examen y opinión sin que esto signifique que el Congreso pueda proponer una modificación que sea vinculante para el Presidente de la República (artículo 5o., Ley de Planeación).

Ahora bien, con la reforma constitucional al artículo 74, fracción VII, en relación con las facultades exclusivas de la Cámara de Diputados cuya vigencia empezará a partir del 1o. de diciembre de 2018, este órgano parlamentario deberá aprobar el Plan que le presente el Ejecutivo federal en el plazo que disponga ley, de no hacerlo en ese plazo, se entenderá aprobado. De tal forma, que el acto legislativo que lleve a cabo la Cámara de Diputados para aprobar el Plan, debe entenderse como un acto con efectos generales, como si de una ley se tratase. Pero si no lo aprueba en dicho término y opera la afirmativa ficta isigue siendo un acto administrativo con efectos limitados? Basta que la mayoría parlamentaria en dicha cámara deje transcurrir el plazo que deberá estar previsto en ley para que el Plan del Ejecutivo Federal pase íntegro, sin modificación alguna. Esta disposición prevé desde este momento grandes problemas jurídicos de interpretación. Pero lo importante a resaltar es que la ley que regule este procedimiento de aprobación debe mejorarse para que la participación ciudadana, sea ésta a través de la elaboración del Plan, o sea a través de la representación nacional conforme a la nueva disposición constitucional, respete e incluya la decisión de

ciones: 129,299 personas respondieron la encuesta interactiva, los Foros y Mesas Sectoriales contaron con 61,779 asistentes y se recibieron 37,871 propuestas físicas y electrónicas. Los diferentes insumos del proceso de consultas contribuyeron al diseño de metas, objetivos, estrategias y líneas de acción del presente Plan Nacional de Desarrollo". Información disponible en: http://pnd.gob.mx, última consulta realizada el 12 de octubre de 2016. 
Este libro forma parte del acervo de la Biblioteca Jurídica Virtual del Instituto de Investigaciones Jurídicas de la UNAM

la población en general en la medida de lo posible; con ello habremos dado un paso más hacia la protección y cuidado de los derechos humanos.

La práctica es que la participación ciudadana en la confección del Plan a través de la página de Internet que se habilita para tal efecto, contiene preguntas previamente establecidas sobre temas generales como salud, seguridad, etcétera, y se deja algún espacio limitado a cierto número de caracteres para dar una opinión adicional, lo cual cercena visiblemente la participación de la población.

En relación con la posibilidad de que los foros de consulta permanente o los que se lleven a cabo para tales efectos, a fin de rectificar el Plan o los programas gubernamentales, tienen derroteros similares. Si no se convoca una consulta popular, porque no es obligatorio, no existe posibilidad alguna de que los ciudadanos participen en la modificación o rectificación del Plan o de los programas; pero aun convocándose, el artículo 31 de la Ley de Planeación establece que los resultados de las revisiones y, en su caso, las adecuaciones consecuentes al Plan y los programas, deberán ser aprobados por el Ejecutivo Federal. De igual forma, las observaciones a la ejecución, revisión y adecuaciones al Plan y sus programas durante la vigencia y ejercicio del mismo, no son vinculantes para el Ejecutivo federal; sólo son opiniones que podrá o no tomarlas en cuenta (artículo 5o.). Por tanto, la esperanzadora participación ciudadana en la gestión de los programas gubernamentales y del Plan que parece permitir la Constitución, se ve acotada, por la Ley de Planeación, dejando sin herramientas jurídicas al ciudadano en esta etapa del ciclo presupuestario para intervenir en las políticas públicas.

$\mathrm{Al}$ anterior ejercicio democrático fingido, habrá que agregar un aspecto más que tiene que ver con la limitación de las consultas populares.

Es derecho de los ciudadanos, establece el recién reformado artículo 35 constitucional (DOF, 10 de febrero de 2016), votar en las consultas populares sobre temas de trascendencia nacional, pero no podrán ser objeto de estas los ingresos y gastos del Estado. Parece obvio y así debe ser, que el pago de impuestos no sea motivo de consulta popular. ¿Qué ciudadano no quiere pagar menos impuesto o que sea relevado del pago de uno de ellos? Pero no parece tan obvio en cuanto al gasto. Inclusive - a mi modo de ver - esta disposición constitucional podría hacer nugatoria la posibilidad de realizar presupuestos participativos en los que se le pregunta a la población las necesidades que consideran prioritarias y con ello destinar una pequeña parte del presupuesto a atenderlas, por ejemplo, alumbrado público, banquetas, mercados, rastros, etcétera.

Es cierto que las consultas populares y el procedimiento de los presupuestos participativos se llevan a cabo en momentos diferentes del ciclo pre- 
Este libro forma parte del acervo de la Biblioteca Jurídica Virtual del Instituto de Investigaciones Jurídicas de la UNAM

supuestario y son figuras jurídicas diferentes. Las primeras durante el mismo y los segundos al momento de la elaboración del presupuesto general, no obstante ni la Constitución ni la Ley de Consulta Popular establecen una limitación o habilitación temporal de ambos procedimientos, y habrá que tomar en cuenta que los dos procedimientos se refieren al gasto público. En todo caso el debate queda abierto, pues en varias ciudades de la República ya se han aplicado sin que se cuestione su constitucionalidad.

Lo importante a señalar es que - en mi opinión-, el gasto público no debió limitarse en el objetivo de las consultas públicas. En cualquier caso debió limitarse a ciertos aspectos del gasto público, probablemente salarios, ciertos gastos administrativos, algunos gastos de inversión, pero debió dejar abierta la posibilidad de opinar sobre gastos relacionados con los servicios públicos y la prioridad que tiene la población sobre los mismos.

\section{ELABORAGiÓN}

La fase de elaboración del presupuesto consiste, grosso modo, en la conjunción de todos los anteproyectos de presupuesto de todas las dependencias y entidades de la administración pública federal para integrar lo que será el proyecto de Presupuesto de Egresos de la Federación, el cual deberá ser remitido por el presidente de la República a la Cámara de Diputados para su examen y, en su caso, modificación de conformidad con el artículo 74 constitucional. Dichos anteproyectos deberán contar con el visto bueno de la Secretaría de Hacienda y Crédito Público (SHCP), pero en el caso de ciertos órganos del Estado si bien sus anteproyectos de presupuesto se integran al proyecto del Ejecutivo, no requieren la anuencia de la SHCP ya que son entes públicos que gozan de autonomía presupuestaria por disposición constitucional. Son los casos por ejemplo de la Comisión Nacional de los Derechos Humanos, el Instituto Nacional de Estadística y Geografía, entre otros, y en algunos casos los anteproyectos se sujetan a ciertos límites establecidos por la autonomía presupuestaria que establece el artículo 5o. de la Ley Federal de Presupuesto y Responsabilidad Hacendaria (LFPRH) o por la ley de creación del ente público, como en el caso de la Comisión Federal de Electricidad o de Petróleos Mexicanos en los que su anteproyectos de presupuesto se sujetan a los techos de gasto previamente establecidos por la SHCP y alguna otra modalidad.

Pues bien, en esta fase del procedimiento del ciclo presupuestario, es difícil encontrar un reducto mediante el cual tenga participación la población en general. La elaboración del Presupuesto de Egresos es un procedimiento interno, con base constitucional y legal, pero cuyos términos o propuestas 
Este libro forma parte del acervo de la Biblioteca Jurídica Virtual del Instituto de Investigaciones Jurídicas de la UNAM

no están sujetos a la opinión de la sociedad civil. Encontramos, no obstante lo anterior, un medio de participación ciudadana en esta fase del ciclo presupuestario: los presupuestos participativos.

Las características de otras técnicas de presupuestación como el presupuesto Ejecutivo, el presupuesto por programas o el presupuesto base cero, no permiten la participación ciudadana.

El presupuesto participativo, como técnica presupuestaria con características propias, nace en la ciudad de Porto Alegre, Brasil, con base en la promulgación de una nueva Constitución brasileña el 5 de octubre de 1998, y se empieza a aplicar en 1989 con gran éxito. Otras ciudades del mundo (Buenos Aires, Sabadell y Rubí en España, Cerro Navia en Chile) también han aplicado esta técnica con diferentes resultados. En la Ciudad de México se viene aplicando normalmente desde hace algunos años, y cuyos resultados vinculan al Ejecutivo local y por supuesto a los parlamentos locales.

La limitante que tienen los presupuestos participativos es que deben aplicarse respecto de una parte del presupuesto global y en relación con ciertos temas, pues no todos deben ni pueden incluirse en esta consulta. Asimismo, la apatía poblacional en dicha participación y la falta de información sobre los beneficios de los mismos, hacen de estos una vía poco efectiva para solicitar al gobierno local la atención de los derechos de los ciudadanos y por tanto de la protección y cuidado de los derechos humanos. No obstante lo dicho, es un paso más que abona la democratización del presupuesto y el acercamiento, para quien ejerce dicho derecho, a las cuentas públicas del gobierno local y de alguna forma para el control de las mismas.

\section{EJEGUGIÓN}

En cuanto a la participación ciudadana en la ejecución del gasto público, ya hemos visto que el procedimiento previsto para la revisión y modificación de los programas gubernamentales, inhibe la efectividad de aquella. Pero el ejercicio incorrecto o deficiente del gasto público en algunos rubros puede tener efectos devastadores en la ciudadanía y no existe un procedimiento que vele por el cuidado de dichos derechos.

También son importante los efectos negativos en relación al respecto de derechos humanos y la gran dificultad para exigir su cumplimiento al Estado condenado por un juez o tribunal, sobre todo cuando se trata de una suma de dinero, pues el procedimiento presupuestario vigente articula una serie de obstáculos que impiden el cumplimiento cabal de las sentencias. 
Este libro forma parte del acervo de la Biblioteca Jurídica Virtual del Instituto de Investigaciones Jurídicas de la UNAM

Anunciados estos dos temas, y sin ánimo de extenderme porque el espacio lo impide, empezaré por el primero y respecto del cual sólo voy a poner un ejemplo de entre otros tantos: los subsidios. Después entraré al segundo tema señalado.

\section{Subsidios}

Los subsidios son los recursos públicos considerados dentro del gasto federalizado que el gobierno federal transfiere a las entidades federativas y municipios a través de las dependencias y entidades de la administración pública federal, para beneficiar a dichas entidades federativas, municipios y a los diferentes sectores de la sociedad (individuos o grupos sociales), a efecto de fomentar el desarrollo de actividades sociales o económicas prioritarias.

El efecto de la entrega de los subsidios entre la población en general es de suma trascendencia presupuestaria, pues implica una gran cantidad de dinero público ${ }^{6}$ derivado de lo cual la legislación presupuestaria ha sido muy estricta en el otorgamiento de los mismos, sujetándolos a los principios de objetividad, equidad, transparencia, publicidad, selectividad y temporalidad, y estableciendo unas obligaciones muy claras para las dependencias y entidades a través de las cuales se otorgan. Sólo mencionaré algunas para recalcar la importancia del otorgamiento de los subsidios a la población, en este sentido las dependencias y entidades deberán (artículo 75, LFPRH):

i) identificar con precisión a la población objetivo, tanto por grupo específico como por región del país, entidad federativa y municipio; ii) prever montos máximos por beneficiario y por porcentaje del costo total del programa; iii) procurar que el mecanismo de distribución, operación y administración otorgue acceso equitativo a todos los grupos sociales y géneros; iv) Garantizar que los recursos se canalicen exclusivamente a la población objetivo y asegurar que el mecanismo de distribución, operación y administración facilite la obtención de información y la evaluación de los beneficios económicos y sociales de su asignación y aplicación; así como evitar que se destinen recursos a una administración costosa y excesiva; v) asegurar la coordinación de acciones entre dependencias y entidades, para evitar duplicación en el ejercicio de los recursos y reducir gastos administrativos, vi) prever la temporalidad en su otorgamiento.

6 Entre las transferencias, subsidios y donativos, el monto de recursos públicos asciende a un aproximado de entre el 40\% y 50\% del total de Presupuesto de Egresos de la Federación. 
Este libro forma parte del acervo de la Biblioteca Jurídica Virtual del Instituto de Investigaciones Jurídicas de la UNAM

Estos requisitos del procedimiento de otorgamiento, nos da cuenta de la importancia de los mismos como un mecanismo del Estado para atender a la población más vulnerable, pero también nos recuerda la importancia de su control. Ahora bien, ¿Qué pasa si no se cumplen algunos de estos supuestos? ¿Quién puede suspenderlos y destinar el dinero de los mismos a otros fines públicos?

La segunda oración del artículo 74 de la LFPRH, establece:

La Secretaría podrá reducir, suspender o terminar la ministración de subsidios y transferencias cuando las dependencias y entidades no cumplan lo establecido en esta Ley, informando a la Cámara de Diputados y tomando en cuenta la opinión de la misma en el destino de los recursos correspondientes.

Varias cosas por comentar. Aunque me desvíe un poco del foco de este trabajo, pero que afecta sin duda a la democracia de este país, es la alarmante discrecionalidad que otorga la ley presupuestaria al Ejecutivo federal, a través de la SHCP, no solamente para, reducir suspender o terminar la ministración de fondos (que ya es mucho, como se verá enseguida), sino la inocua y hasta risible medida de control legal que obliga a la SHCP de sólo informar a la Cámara de Diputados sobre la decisión ya tomada con anterioridad por dicha dependencia, y a únicamente tomar en cuenta la opinión del órgano de representación para variar el destino de los recursos; de tal suerte que queda al libre albedrío de la SHCP decidir el destino o la reasignación de dichos recursos, cuando en realidad se trata de una facultad expresamente reconocida a la Cámara de Diputados en el artículo 74 constitucional.

Es cierto que, aunque la CPEUM no lo diga expresamente, es el Ejecutivo federal el único encargado del ejercicio administrativo del gasto público una vez aprobado el Presupuesto de Egresos de la Federación por la Cámara de Diputados, pero precisamente porque cuenta con la autorización y mandato de la representación nacional. Autorización que implica el cómo, el cuánto y el cómo debe el Ejecutivo federal ejercer esos recursos, esta es una regla presupuestaria básica y cuya delgada línea fija la frontera entre un país democrático y un país autoritario. Entonces, ¿cómo es posible que los gastos aprobados en esa triple vertiente del principio de especialidad presupuestaria, por la Cámara de Diputados, puedan ser alterados o modificados por el gobierno sin autorización de los diputados y con la sola obligación de informarles sobre dicha decisión? Estamos frente a una clara vulneración de las facultades constitucional presupuestarias de la Cámara baja, porque 
Este libro forma parte del acervo de la Biblioteca Jurídica Virtual del Instituto de Investigaciones Jurídicas de la UNAM

la alteración en el destino de los gastos derivada del mal funcionamiento de los subsidios, suplanta y contradice la voluntad de los diputados - en definitiva de los ciudadanos - otorgada al Ejecutivo federal en el momento de la aprobación del Presupuesto de Egresos al inicio del ejercicio fiscal.

En mi opinión, dicha facultad potencializa la incertidumbre del buen ejercicio y control del gasto público y estimula la posibilidad de que los servidores públicos cometan actos de corrupción. Los legisladores que consintieron esta disposición en ocasión de la aprobación de la LFPRH, definitivamente se autolimitaron en sus funciones probablemente sin saberlo (patere quam ipse fecisti legem).

Retomando el hilo del presente trabajo, y concomitantemente a lo expresado, la decisión de suspender, reducir o terminar el otorgamiento de un subsidio, afecta directamente a la población. Parece como si la ley, con dicha suspensión, quisiese castigar a la dependencia o entidad que no verificó el correcto otorgamiento de los subsidios, pero en realidad a quien afecta en última instancia es a los derechos de los grupos sociales y de los individuos.

Concluyendo, en mi opinión la decisión del Ejecutivo federal para disponer de dichos recursos (que recordemos son muy cuantiosos) no puede estar por encima de lo que al efecto establezca el órgano legislativo. Es cierto que si la ley establece ciertos requisitos para ser acreedores a los subsidios, también es cierto que una vez cumplidos los requisitos, las dependencias y sobre todo las entidades deben recibir sus recursos autorizados legislativamente sin que puedan ser suspendidos o reducidos sin la autorización expresa de la Cámara de Diputados quien autorizó y ordenó el destino de los mismos. En todo caso esa medida debiera aplicarse cuando mucho a las dependencias, pero no a las entidades que en muchos casos gozan de autonomía.

Una vez más, con estas disposiciones legales se afectan los derechos humanos de los ciudadanos que de repente, y sin ser ellos responsables directamente, les suspenden, reducen o suspenden los recursos públicos con los cuales se ayudan en sus actividades económicas diarias.

\section{Los derechos de los acreedores del Estado}

El otro tema a abordar y que anunciamos al principio de este rubro tiene que ver con la difícil vía legal con la que se encuentran los acreedores del Estado, cuando un juez o un tribunal le condena a este último al pago de una suma de dinero. 
Este libro forma parte del acervo de la Biblioteca Jurídica Virtual del Instituto de Investigaciones Jurídicas de la UNAM

En este rubro me centraré a partir del momento en el que ya existe una sentencia firme en la que se condena al Estado al pago de una cantidad de dinero, porque es en este momento en donde se revelan los problemas presupuestarios para cobrarle al gobierno y en consecuencia provocan diferentes agravios a los ciudadanos. La ley presupuestaria ha sido muy cautelosa para inclinar la balanza a favor de la protección de los intereses del gobierno en detrimento de los derechos de sus acreedores.

Para el estudio de este tema habrá que diferenciar dos tipos de regímenes en cuanto a la exigibilidad de los derechos de los acreedores del Estado, derivados de una sentencia condenatoria de carácter pecuniaria. El régimen general y el régimen de responsabilidad patrimonial del Estado. Sobre este último no entraré a su revisión, pues ya lo he hecho con mayor detenimiento en otro lado, ${ }^{7}$ y rebasaría con mucho el alcance del presente artículo.

En cuanto al régimen general es importante señalar los límites y restricciones que tiene la legislación en la materia cuya regulación es, en mi opinión, claramente favorecedora de los intereses del Estado, pues con base en ella se elude el pago derivado de mandamiento judicial y retrasa el cumplimiento del pago, provocando con ello el aplazamiento de la atención a los derechos humanos de los ciudadanos en su vertiente de una justicia pronta y expedita garantizada por el artículo 17 constitucional.

Las reglas para proceder al pago de resoluciones definitivas, se establecen en el artículo 47 de la LFPRH que a la letra dice:

Los ejecutores de gasto, con cargo a sus respectivos presupuestos y de conformidad con las disposiciones generales aplicables, deberán cubrir las contribuciones federales, estatales y municipales correspondientes, así como las obligaciones de cualquier índole que se deriven de resoluciones definitivas emitidas por autoridad competente. Las adecuaciones presupuestarias que, en su caso, sean necesarias para el pago de las obligaciones a que se refiere la parte final del párrafo anterior, no podrán afectar el cumplimiento de los objetivos y las metas de los programas prioritarios aprobados en el Presupuesto de Egresos. Las dependencias y entidades que no puedan cubrir la totalidad de las obligaciones conforme a lo previsto en el párrafo anterior, presentarán ante la autoridad competente un programa de cumplimiento de pago que deberá ser considerado para todos los efectos legales en vía de ejecución respecto de la resolución que se hubiese emitido, con la finalidad de cubrir las obligaciones hasta por un monto que no afecte los objetivos y metas de los programas prioritarios, sin perjuicio de que el resto de la obligación deberá pagarse en los ejercicios fiscales subsecuentes conforme a dicho programa.

7 Véase Nava Escudero, Óscar, Derecho presupuestario mexicano, México, Porrúa, 2014, pp. 677 y ss. 
Este libro forma parte del acervo de la Biblioteca Jurídica Virtual del Instituto de Investigaciones Jurídicas de la UNAM

Habrá que analizar con detalle esta disposición. Los ejecutores de gasto con cargo a sus respectivos presupuestos deberán cubrir las obligaciones de cualquier indole que se deriven de resoluciones definitivas emitidas por autoridad competente.

Esta primera afirmación nos arroja que para tales obligaciones no existe en el Presupuesto de Egresos de la Federación un fondo, como sucede en otros países, para afrontar estos gastos ${ }^{8}$ ni existe la obligación de prever una partida presupuestaria en los proyectos de Presupuesto de Egresos de los ejecutores de gasto para hacer frente a este tipo de obligaciones.

Asimismo, de este párrafo se desprende lo que la doctrina internacional conoce como el "principio de autotutela" o "autoejecución administrativa" de sentencias condenatorias del Estado. ${ }^{9}$ Este principio es un privilegio otorgado al Estado el cual brinda la posibilidad legal de que sea la misma autoridad infractora la que ejecute o cumpla la sentencia que le condena. Conforme al Diccionario de la Real Academia de la Lengua, el verbo "cubrir", entre otras tantas acepciones a que se refiere el párrafo aludido, significa "pagar o satisfacer una deuda o una necesidad, gastos o servicios", por lo que, según la redacción de nuestra ley presupuestaria, es el ejecutor de gasto quien deberá proveer dinero para afrontar el pago derivado de obligaciones de cualquier índole, lo cual deja al mismo sujeto condenado el cumplimiento de su sentencia. Lo contrario a la autoejecución que pregona nuestra LFPRH sería la ejecución forzosa cuyo cumplimiento se realiza aun en contra de la voluntad del condenado en sede del derecho privado, y que actualmente no es viable en nuestra legislación. "Los pagos se realizarán mediante adecuaciones presupuestarias, las cuales no podrán afectar el cumplimiento de los objetivos y metas de los programas prioritarios".

Esta parte del artículo en escrutinio, significa que es la misma autoridad administrativa (el mismo ejecutor de gasto condenado) quien deberá realizar o, en su caso, solicitar autorización, para llevar a cabo la adecuación a su presupuesto para hacer frente a este pago. Recordemos que de conformidad con la LFPRH y su Reglamento existen ciertas reglas para realizar

8 La legislación española, por ejemplo, prevé un fondo de contingencia de ejecución presupuestaria cuya principal misión es hacer frente a necesidades inaplazables, de carácter no discrecional para las que no se hiciera en todo o en parte la adecuada dotación de crédito. Esto significa que el dinero depositado en el fondo ( $2 \%$ del total de gastos para operaciones no financieras) es susceptible de ser utilizado para atender gastos derivados de una sentencia condenatoria a las administraciones públicas españolas, no obstante, la autorización para realizar dicha operación recae en el acuerdo que al respecto emita el Consejo de Ministros, dependiente del gobierno central, por tanto, la dotación de dinero para tal causa depende de la voluntad del mismo ejecutado.

9 Por todos, véase García de Enterría, Eduardo y Fernández, Tomás-Ramón, Curso de derecho administrativo, 13a. ed., Madrid, Cívitas, 2006, t. I, pp. 51, 52 y 512, passim. 
Este libro forma parte del acervo de la Biblioteca Jurídica Virtual del Instituto de Investigaciones Jurídicas de la UNAM

las correspondientes adecuaciones presupuestarias y que en algunos casos requieren de la autorización de la SHCP o del respectivo órgano de gobierno. De esta forma, lo que deja claro la ley presupuestaria es que el cumplimiento presupuestario de la resolución emitida por la autoridad queda al arbitrio del ejecutor de gasto, pues en todo caso es éste quien debe activar el mecanismo presupuestario de la adecuación. Por lo tanto, el acreedor del Estado está a la espera de un acto de buena fe de la administración para realizar la adecuación correspondiente y colmar de recursos la partida presupuestaria de su crédito.

Ahora bien, esas adecuaciones que realice el ejecutor de gasto no deben afectar el cumplimiento de objetivos y metas de programas prioritarios. ¿Cuáles son los programas prioritarios?, a mi modo de ver, y a falta de regulación legal sobre este asunto, cualquier programa de gasto podría considerarse prioritario porque, ¿quién se encarga de decidir si un programa es prioritario o no? Entendemos que la misma administración, por tanto basta que el ejecutor del gasto alegue que dicha adecuación afectaría al cumplimiento de alguno de sus programas para evadir el cumplimiento de la sentencia que le condena.

Es cierto, por otro lado, que si forzamos al ente público a realizar la adecuación correspondiente, se corre el riesgo de afectar o dejar sin fondos algún programa de repercusión social, como los de educación, y que inciden directamente en la población; pero hay que insistir que, quien incumplió fue el ejecutor de gasto, por eso la responsabilidad del cumplimiento de la sentencia condenatoria no debiera afectar al deudor crediticio, sino que debe castigar a la parte que incumplió con su obligación.

Si no existen recursos, se deberá realizar un programa de cumplimiento de pago que no deberá afectar los objetivos y metas de los programas prioritarios y cuyo resto de pago deberá hacerse en los ejercicios fiscales subsecuentes. Dicho programa se considerará en vía de ejecución respecto de la resolución que se hubiese emitido.

Lo anterior supone que si aun realizadas las adecuaciones presupuestarias por el ejecutor de gasto y éstas no fuesen suficientes para dotar de recursos públicos la partida presupuestaria, la ley permite que el ejecutor del gasto condenado presente ante la autoridad competente un programa de cumplimento de pago con la finalidad de cubrir las obligaciones hasta por un monto que no afecte los objetivos y metas de los programas prioritarios, debiéndose pagar el resto de la obligación en los ejercicios fiscales subsecuentes (2, 3 o 4 años), sin que los montos de esos ejercicios futuros tampoco 
Este libro forma parte del acervo de la Biblioteca Jurídica Virtual del Instituto de Investigaciones Jurídicas de la UNAM

afecten las metas y objetivos de sus programas, con lo cual el pago puede prorrogarse, sin exageración, ad infinitum.

El fraccionamiento del pago de una obligación derivada de una sentencia condenatoria del Estado es una opción a que han recurrido múltiples países con el fin de no afectar sus finanzas públicas, lo cual, por otro lado, también parece no necesitarse, pues no se ha sabido que un pago de estas características afecte las finanzas de un Estado. ${ }^{10}$

El hecho de que el programa de cumplimiento de pago sea para todos los efectos legales en vía de ejecución respecto de la resolución que se hubiese emitido, significa que para su pago en los subsecuentes ejercicios fiscales, no se requiere nuevamente de un pronunciamiento judicial de ninguna especie ni el reconocimiento de dicha obligación por parte de ninguna autoridad, pues se entiende que dichos pagos se realizan en automático, el problema surge - a nuestro modo de ver - cuando mientras no se presente ese programa de cumplimiento de pago, no se podrán afrontar los gastos de dichas obligaciones.

Las erogaciones para cubrir indemnizaciones y las obligaciones citadas, se consideran gastos obligatorios. En este punto, la ley junto con su reglamento estipulan que los gastos derivados de este tipo de obligaciones del Estado se considerarán como obligatorios. Los gastos obligatorios son aquéllos que no podrán dejar de señalarse en el proyecto de Presupuesto de Egresos del Ejecutivo Federal ni en el Presupuesto de Egresos de la Federación que apruebe la Cámara de Diputados. Son gastos que forzosamente deberán incluirse en el Presupuesto.

La declaración de estos gastos como obligatorios, prima facie, parecería ser de un gran avance y suponer una garantía plena para los ciudadanos de que el Estado incluirá en sus presupuestos el pago de sus condenas en tiempo y forma; pero este estado idílico no es así, habida cuenta del procedimiento establecido en el mismo artículo 47 que estamos analizando, el cual establece en términos general un procedimiento largo y probablemente sin fin.

Por tanto - a nuestro parecer-, el calificativo a ese tipo de gastos como obligatorios que establece la ley, es ilusorio o aparente, pues los verdaderos

10 A este respecto, Castro Estrada, Álvaro, Responsabilidad patrimonial del Estado, 3a. ed., México, Porrúa, 2006, p. 20, ha dicho "habría que apuntar en este momento que no hemos encontrado alguien que en forma científica haya demostrado los efectos amenazantes que se le pretenden atribuir. Tampoco hemos podido identificar cifras presupuestales o estadísticas totales y confiables, que en países que han adoptado desde hace muchos años esta institución, demuestren la excesiva carga financiera que algunos suponen tendría su adopción integral". 
Este libro forma parte del acervo de la Biblioteca Jurídica Virtual del Instituto de Investigaciones Jurídicas de la UNAM

gastos obligatorios en otras latitudes del globo terráqueo no se sujetan a los límites que exige el artículo señalado. De ser efectivamente obligatorios, la resolución de la autoridad que condenase al Estado, generaría por si misma el crédito presupuestario suficiente para atender este tipo de obligaciones, cosa que no sucede de lege data en nuestra legislación.

El esquema así planteado por la ley presupuestaria con modalidades y límites de cumplimiento, evidencia lo difícil que supone para el particular que su pago se realice con prontitud como exige el artículo 17 constitucional. La ley presupuestaria otorga muchas facilidades al ejecutor de gasto para resolver el cumplimiento de sus obligaciones (que al cabo del tiempo se convierte en un incumplimiento velado) pero ninguna para resguardar los derechos del particular afectado que observa como la posibilidad del cobro de su crédito se aleja cada vez más.

\section{El derecho a una justicia pronta y expedita vs. el principio de legalidad presupuestaria}

El principio de legalidad presupuestaria exige que no se realice pago alguno si no es mediante el Presupuesto de Egresos o mediante ley posterior (artículo 26 constitucional). Esto significa que sólo a través de estos dos medios se puede pagar una obligación del Estado ya sea esta voluntaria o legal/contractual. De lo contrario, es decir, de realizar un gasto sin sustento en estas dos únicas vías supondría la realización de un acto administrativo de disposición de gasto contra legem. En materia presupuestaria, el acto administrativo de disposición de gasto (en las obligaciones voluntarias del Estado) debe cumplir con la regla conocida como la doble condicionalidad de la acción administrativa en donde la administración, al dictar un acto que suponga la disposición de dinero público, debe atender a dos ámbitos: el sustantivo, en cuanto atribución genérica de potestad y al aspecto materialfinanciero, en cuanto autorización económica necesaria para toda actividad del gobierno en la que utilice dinero público. ${ }^{11}$

11 Podemos aventurarnos a decir que, si bien los actos administrativos se presumen legítimos, cuando esos mismos actos pretenden disponer del dinero público deben cumplir con el aspecto material financiero, de tal suerte que la presunción de legitimidad del acto administrativo se desvanece si no se cumple con la legalidad presupuestaria; es decir, la legalidad presupuestaria se convierte así en un principio claramente disuasorio de la presunción de legitimidad del acto administrativo de disposición de gasto público. Véase Nava Escudero, Óscar, El Estado deudor frente a sus acreedores. (La exigibilidad de las obligaciones de la Hacienda Pública), Madrid, Instituto de Estudios Fiscales, Ministerio de Economía y Hacienda, 2006, p. 228. 
Este libro forma parte del acervo de la Biblioteca Jurídica Virtual del Instituto de Investigaciones Jurídicas de la UNAM

Si derivado de la actividad administrativa financiera del Estado, este incumple con alguna de sus obligaciones legales o contractuales y el juez o el tribunal le condena a pagar una cantidad de dinero - a mi modo de ver-, esa resolución judicial debiera generar por sí misma el crédito presupuestario suficiente para atender y cumplir con lo ordenado por el juez, sin que dicho cumplimiento se supedite a ninguna condición. No obstante la propuesta anterior, como hemos revisado en el apartado precedente, las reglas de cumplimiento vigentes derivadas de estos supuestos de condena no dan cabida a que el crédito presupuestario se genere de forma automática para satisfacer el derecho del acreedor, toda vez que el Estado debe atender a lo que le señala la ley para cumplir con su condena.

De esta forma, la ley presupuestaria le brinda la oportunidad al Estado de alegar el respeto al principio de legalidad presupuestaria (artículo 126 constitucional) para abstenerse de pagar o de pagar tardíamente, de tal modo que dicha alegación puede convertirse en una espiral interminable que difícilmente podrá ser superada por el particular afectado que observa cómo su derecho al crédito no se resuelve de forma expedita, pero que además no sabe si se incluirá o no en los presupuestos venideros.

Así, el principio de legalidad presupuestaria pasa de ser un principio rector y garantista del ejercicio del gasto público a ser un instrumento al servicio del Estado para incumplir con sus obligaciones.

El entramado legal presupuestario revisado y la posibilidad legal otorgada al Estado para cumplir tardíamente con las obligaciones de pago que derivan de una sentencia condenatoria, se confrontan con la necesidad de que la administración de justicia sea pronta y completa a que obliga el artículo 17 constitucional.

Este precepto en su párrafo segundo dice:

Toda persona tiene derecho a que se le administre justicia por tribunales que estarán expeditos para impartirla en los plazos y términos que fijen las leyes, emitiendo sus resoluciones de manera pronta, completa e imparcial. Su servicio será gratuito, quedando, en consecuencia, prohibidas las costas judiciales.

Lo anterior sugiere, entre otros extremos, que la justicia debe otorgarse rápidamente, sin dilaciones, de lo contrario se entenderá como la denegación de la misma; lo que en términos anglosajones se conoce como $A$ delayed justice is a denied justice.

El derecho a un proceso sin dilaciones indebidas puede concebirse como un derecho subjetivo constitucional, de carácter autónomo, aunque 
Este libro forma parte del acervo de la Biblioteca Jurídica Virtual del Instituto de Investigaciones Jurídicas de la UNAM

instrumental del derecho a la tutela judicial, que asiste a todos los sujetos del derecho privado que hayan sido parte en un procedimiento judicial y que se dirige frente a los órganos del Poder Judicial, aun cuando en su ejercicio han de estar comprometidos todos los demás poderes del Estado, creando con él la obligación de satisfacer dentro de un plazo razonable las pretensiones y resistencias de las partes o de realizar sin demora la ejecución de las sentencias. ${ }^{12}$ Del tal modo, que el retraso en el otorgamiento de la justicia (indebida, hay que enfatizar) puede suponer una verdadera vulneración en los derechos humanos del particular acreedor del Estado.

Pero el parágrafo constitucional citado también sugiere que la garantía de justicia pronta y completa comprende también la ejecución de lo declarado en la sentencia y que el fallo sea efectivo, es decir, que se cumpla completamente y no a mitades.

La Suprema Corte mexicana ha señalado con toda exactitud el alcance del principio de tutela judicial efectiva, previsto en el artículo 17 constitucional:

1. Justicia pronta, que se traduce en la obligación de las autoridades encargadas de su impartición, de resolver las controversias ante ellas planteadas, dentro de los términos y plazos que para tal efecto se establezcan en las leyes; 2. Justicia completa, consistente en que la autoridad que conoce del asunto emita pronunciamiento respecto de todos y cada uno de los aspectos debatidos, cuyo estudio sea necesario; y garantice al gobernado la obtención de una resolución en la que, mediante la aplicación de la ley al caso concreto, se resuelva si le asiste o no la razón sobre los derechos que le garanticen la tutela jurisdiccional que ha solicitado; 3. Justicia imparcial, que significa que el juzgador emita una resolución, no sólo apegada a derecho, sino, fundamentalmente, que no dé lugar a que pueda considerarse que existió favoritismo respecto de alguna de las partes o arbitrariedad en su sentido; y 4. Justicia gratuita, que estriba en que los órganos del Estado encargados de su impartición, así como los servidores públicos a quienes se les encomienda dicha función, no cobrarán a las partes en conflicto emolumento alguno por la prestación de ese servicio público. Ahora bien, si dicha garantía está encaminada a asegurar que las autoridades encargadas de aplicarla, lo hagan de manera pronta, completa, gratuita e imparcial, es claro que las autoridades que se encuentran obligadas a la observancia de la totalidad de los derechos que la

12 Véase Gimeno Sendra, Vicente, Constitución y proceso, Madrid, Tecnos, 1998, p. 137. Aunque también hay que aceptar, por otro lado, que la celeridad y la rapidez no son bienes procesales supremos; el proceso, para ser justo y conceder oportunidades a los contendientes y al juez, por supuesto, requiere tiempo. Véase De la Oliva Santos, Andrés, "La demolición de la administración de justicia en la futura constitución de 1978", Comunicación a la XIV reunión de profesores de derecho procesal de las universidades del Estado español, España, s.e., 1978, p. 409. 
Este libro forma parte del acervo de la Biblioteca Jurídica Virtual del Instituto de Investigaciones Jurídicas de la UNAM

integran son todas aquellas que realizan actos materialmente jurisdiccionales, es decir, las que en su ámbito de competencia tienen la atribución necesaria para dirimir un conflicto suscitado entre diversos sujetos de derecho, con independencia de que se trate de órganos judiciales, o bien, sólo materialmente jurisdiccionales. $^{13}$

La doctrina, por su parte, ha dicho claramente, que el derecho a una tutela judicial efectiva según lo prevé nuestro artículo 17 constitucional, surte sus efectos en tres momentos distintos: primero, el acceso a la jurisdicción, que significa evitar que se obstaculice el acceso a los órganos jurisdiccionales e impedir que se conozca una pretensión por parte de los órganos jurisdiccionales; segundo, en el proceso mismo, que implica que una vez logrado el acceso, se debe asegurar se siga un proceso que permita que el actor plantee sus pretensiones y el demandado se defienda y, además, que se obtenga una solución en un plazo razonable y, tercero, eficacia de la resolución, es decir, que una vez que se dicte la sentencia, haya una plena ejecución de ésta. ${ }^{14}$

De ahí que habrá que despojar al Estado de la posibilidad de argumentar el apego al principio la legalidad presupuestaria si con dicha acción pretende evadir sus responsabilidades o, en suma, denegar o retrasar el acceso a la justicia.

La colisión surge, como se anunció en el título del presente rubro, en saber si debe darse preferencia al principio de legalidad presupuestaria (artículo 126 constitucional) por encima del derecho que tiene el particular de recibir una justicia pronta y completa (artículo 17 constitucional). En mi opinión debe primar el espíritu y sentido del legislador otorgado al artículo 17, por encima del principio de legalidad presupuestaria, sobre todo si con apoyo en éste el Estado pretende esquivar, dilatar o incumplir las obligaciones a que se encuentra constreñido.

Finalmente, vale la pena transcribir y comentar brevemente dos razonamientos impecables de la Suprema Corte de Justicia de la Nación, en los que concluye que las sentencias que condenan al Estado al pago de una suma dineraria deben generar automáticamente el crédito presupuestario para atenderlas, sin condición alguna y sin las condiciones o reglas previstas en el artículo 47 de la LFPRH.

13 Tesis 2a. L/2002, Semanario Fudicial de la Federación y su Gaceta, Novena Época, t. XV, mayo de 2002, p. 299.

14 Véase Hallivis Pelayo, Manuel Luciano, "Evolución y perspectivas del contencioso administrativo en México. Tecnología y tutela jurisdiccional”, México, Porrúa-UNAM, Instituto de Investigaciones Jurídicas, Facultad de Derecho, Estudios jurídicos en homenaje a Alfonso Nava Negrete. Administración pública contemporánea. Derecho, política y justicia, 2010, t. III, p. 183. 
Este libro forma parte del acervo de la Biblioteca Jurídica Virtual del Instituto de Investigaciones Jurídicas de la UNAM

\section{En uno de ellos sentencia la Corte:}

La resolución incidental de daños y perjuicios, como cumplimiento sustituto de una sentencia de amparo, que establece la condena al pago de una cantidad líquida, cierta y determinada, derivada de un procedimiento en el cual se le respetó a la autoridad responsable el derecho procesal de audiencia, constituye una obligación lisa y llana, cuyo cumplimiento y eficacia no se encuentran condicionados a que la autoridad responsable gestione y obtenga la partida presupuestal destinada específicamente para su pago. Lo anterior es así, en virtud de que existe una responsabilidad del Estado en la satisfacción de los deberes esenciales para restituir al gobernado en el goce de sus garantías individuales violadas, entendida ésta como la obligación ineludible de un órgano del poder público de restituir el perjuicio patrimonial o económico ocasionado a uno de sus gobernados con motivo del indebido ejercicio de la actividad que desempeña, responsabilidad que va más allá de los trámites efectuados para obtener una asignación presupuestaria específica a fin de asumir el pago del débito, pues el cumplimiento de los mandatos de amparo no está sujeto a la voluntad de las autoridades responsables, sino al imperio de la propia Constitución Política de los Estados Unidos Mexicanos; de no ser así, bastaría con que las autoridades obligadas gestionaran debidamente ante las autoridades competentes el otorgamiento de la partida presupuestal correspondiente, para quedar exoneradas de la aplicación de las medidas establecidas en la fracción XVI del artículo 107 de la propia Constitución Federal, aunque aquélla no se otorgara, lo cual permitiría tanto a la autoridad obligada al pago como a aquella que debe autorizar el presupuesto o gasto público de una oficina gubernamental, encontrar un mecanismo para evadir el cumplimiento de una resolución de pago de daños y perjuicios, hasta el grado de que ésta quedara permanentemente incumplida guroso sistema dispuesto en la Norma Fundamental para el cumplimiento de los mandatos de amparo y de la garantía de administración de justicia pronta y expedita prevista en su artículo 17, a favor del gobernado, quien a través del procedimiento de inejecución de sentencia de amparo debe ser restituido en el pleno goce de sus garantías individuales violadas... ${ }^{15}$

\section{En la otra razona de la siguiente forma:}

La Suprema Corte de Justicia de la Nación, fundamentalmente en la Quinta y Sexta Épocas del Semanario Judicial de la Federación, emitió diversas tesis en

15 Sentencias de amparo. el pago de daños y perjuicios, como cumplimiento sustituto de aquéllas, no está condicionado a que la autoridad responsable gestione y obtenga la partida presupuestal correspondiente. Incidente de inejecución 493/2001. Francisco Arteaga Aldana. 28 de febrero de 2002. Once votos. Ponente: Juan Díaz Romero. Secretario: Roberto Rodríguez Maldonado. Tesis Aislada, Semanario fudicial de la Federación y su Gaceta, Novena Época, t. XV, abril de 2002, p. 11. 
Este libro forma parte del acervo de la Biblioteca Jurídica Virtual del Instituto de Investigaciones Jurídicas de la UNAM

las cuales sostuvo el criterio predominante de que tratándose de obligaciones de pago derivadas de sentencias de amparo a cargo de las autoridades responsables, no se sancionaría su incumplimiento cuando el pago no se encontrara previsto en el presupuesto autorizado, de manera que la responsabilidad de aquéllas quedaba limitada a la mera gestión ante los órganos competentes para que se autorizara el gasto correspondiente. ${ }^{16}$ En este sentido se orientan los siguientes criterios históricos, de rubros: "CAASO EN QUE NO ES APLICABLE, DE MOMENTO, LA FRACGIÓN XI EL ARTÍCULO 107 CONSTITUGIONAL. DEFECTO DE EJEGUCIÓN"; "SENTENCIAS DE AMPARO, EJEGUCIÓN DE LAS"; "SENTENCIAS DE AMPARO, INELUDIBLE EJEGUCIÓN DE LAS" e "INCIDENTE DE INEJECUCIÓN DE SENTENCIA IMPROCEDENTE", publicados, respectivamente, en el Informe de 1941, página 131 y en el Semanario fudicial de la Federación, Quinta Época, Tomo XXXI, página 2277 y Tomo XLVII, página 4882, y Sexta Época, Volumen LXXVIII, Primera Parte, página 14. Sin embargo, estos criterios no deben prevalecer en la actualidad pues, por una parte, obedecen a la interpretación aislada del artículo 126 de la Constitución Política de los Estados Unidos Mexicanos (que originalmente era el 125) y, por otra, desconocen la fuerza vinculatoria de las ejecutorias de amparo cuya eficacia deriva del mandato constitucional. Lo anterior es así, pues si bien es cierto que el presupuesto de egresos se rige por el principio de anualidad, porque el ejercicio fiscal, por razones de política tributaria, comprende un periodo de un año, para el cual se planea precisamente el gasto público que implica la programación de actividades y cumplimiento de proyectos al menos durante ese tiempo, también lo es que el citado artículo 126 de la Norma Fundamental acepta que el presupuesto no debe ser estricto, inflexible, ni imposible de modificar, pues prevé la posibilidad de que pueda variarse al establecer que no podrá hacerse pago alguno que no esté comprendido en el presupuesto o determinado por ley posterior, de donde se desprende que en el propio texto de la norma constitucional referida, subyace el principio de modificación presupuestaria, al permitir que el gasto pueda programarse en dos momentos, uno anterior y otro posterior, a saber: a) $\mathrm{Al}$ aprobarse el presupuesto de egresos; o, b) En ley posterior, la que por su cronología necesariamente sucede a aquel proyecto presupuestario original en el tiempo; de manera que el precepto constitucional en mención, en lugar de constituir un valladar insuperable para la autoridad responsable, prevé la posibilidad de modificación del presupuesto original para adecuarlo a las necesidades sobrevenidas, es decir, su virtud es la de establecer un remedio para los casos fortuitos, que le permite solicitar los ajustes presupuestarios necesarios para enfrentar las obligaciones pecuniarias del Estado, gasto que necesaria e

16 Recordemos que este era el criterio que sostenía la abrogada Ley de Depuración de Créditos de 1941, en la cual se trasladaba la responsabilidad del Ejecutivo federal al Poder Legislativo para que fuera de éste el encargado de dotar el correspondiente crédito. Con esto el Estado se lavaba las manos respecto de sus responsabilidades económico-presupuestarias. 
Este libro forma parte del acervo de la Biblioteca Jurídica Virtual del Instituto de Investigaciones Jurídicas de la UNAM

ineludiblemente debe autorizarse por tratarse del cumplimiento de un mandato de amparo cuya ejecución es impostergable. Además, si la autoridad ya tiene autorizado un presupuesto que le permite efectuar un pago, aun cuando no esté previsto específicamente en él, debe realizarlo si con ello da cumplimiento a un mandato de amparo, pues exclusivamente en esta hipótesis no podría considerarse jurídicamente que vulnerara la prohibición contenida en el artículo 126 de la Constitución General de la República, en razón de que el cumplimiento de las sentencias de amparo no puede quedar condicionado a la determinación de si se aprueba o no una partida presupuestal para hacer frente a la obligación impuesta, dado que la majestad de la Constitución Federal impone categóricamente que aquéllas sean cumplidas inexcusablemente, por lo que únicamente en esta hipótesis no puede operar el principio de responsabilidad que deriva del mencionado artículo 126 constitucional, pues técnicamente no se estaría contraviniendo, sino que se actualizaría un caso de excepción en el que no sería punible la conducta de la autoridad...". ${ }^{17}$

Estos brillantes pronunciamientos que no son seguidos por la legislación presupuestaria de nuestro país, son una prueba irrefutable de dos cosas: a) que si bien el ejecutor de gasto (administración pública, en suma) debe respetar el principio de legalidad presupuestaria al momento de realizar un acto administrativo que disponga de recursos públicos o en la celebración de un contrato, la aplicación de dicho principio no debe convertirse en un instrumento al servicio del Estado que impida el cumplimiento de sentencias que le condenen, ${ }^{18}$ y $b$ ) que las sentencias condenatorias del Estado al pago de una suma de dinero generan por sí mismas el gasto que debe asignarse a la partida presupuestaria que hará frente a dicha obligación; en este mismo sentido, ya se ha comentado que

...la obligación de pago determinada por la ejecutoria de amparo no se adquiere en virtud de un compromiso de gasto por parte de la Adminis-

17 "SENTENCIAS DE AMPARO. INTERPRETACión DEL ARTículo 126 DE LA CONSTITUCión Política de los Estados Unidos Mexicanos tratándose de las ObligaCIONES DE PAGO DERIVADAS DE SU CUMPLIMIENTO”. Incidente de inejecución 493/2001. Francisco Arteaga Aldana. 28 de febrero de 2002. Once votos. Ponente: Juan Díaz Romero. Secretario: Roberto Rodríguez Maldonado.

18 En este mismo sentido véase Alvarado Esquivel, Miguel de Jesús, "Puntos críticos en la ejecución de las sentencias de amparo", La Ciencia del derecho procesal constitucional, estudios en homenaje a Héctor Fix-Zamudio, México, UNAM, Marcial Pons, 2008, t. V, p. 242, y Alvarado Esquivel, Miguel de Jesús, "Un extraño ataque a la ejecutorias de amparo: la insuficiencia presupuestaria de las autoridades administrativas", en Nava Escudero, Óscar y Ortega Maldonado, Juan Manuel (coords.), Derecho presupuestario. Temas selectos, México, Porrúa, 2006, pp. 185 y ss. 
Este libro forma parte del acervo de la Biblioteca Jurídica Virtual del Instituto de Investigaciones Jurídicas de la UNAM

tración Pública, sino que es mera e inapelable consecuencia de la propia ejecutoria de amparo dictada por los tribunales del Poder Judicial de la Federación. $^{19}$

De seguirse estos valiosos criterios de la Corte, la protección y resguardo de los derechos humanos de los ciudadanos sería real y tangible. Como brillantemente se ha razonado

...es preciso reforzar la protección de los particulares para que puedan defender sus derechos e intereses legítimos, y evitar su avasallamiento frente a la administración pública, y si bien existen varios instrumentos tutelares de carácter político y social, consideramos que los más importantes son los de naturaleza jurídica, los que se encuentran comprendidos dentro del ámbito de la justicia administrativa. ${ }^{20}$

\section{CONTROL}

Para controlar el ejercicio del gasto público, México cuenta con tres formas de control que son utilizadas en casi todos los países del mundo aunque con características, atribuciones y regímenes jurídicos diferentes.

El control administrativo o interno, corre a cargo de la Secretaría de la Función Pública y de los órganos internos de control en cada uno de los entes públicos de la administración pública federal.

El control externo o jurisdiccional, está en manos de la Auditoría Superior de la Federación (ASF), si bien éste no es un órgano a semejanza de un tribunal de cuentas cuya función primordial es la de impartir justicia, es más parecido al modelo británico de control, en el que el órgano fiscalizador depende en cierta medida del parlamento o de la Cámara de Diputados, como ocurre en el caso mexicano.

Finalmente el control legislativo o político que, como su nombre lo indica, lo realizan los legisladores respecto de la actuación financiera de la administración, y de otros aspectos que las cámaras consideren.

De estas tres vertientes de control, me enfocaré en la referente al control externo que realiza la ASF, pues la reciente reforma en materia de corrupción que crea el Sistema Nacional Anticorrupción introduce el modelo de

19 Idem. p. 205.

20 Fix-Zamudio, Héctor "Aspectos contemporáneos de la justicia administrativa", Estudios jurídicos en homenaje a Alfonso Nava Negrete. Administración pública contemporánea. Derecho, política y justicia, México, Porrúa-UNAM, Instituto de Investigaciones Jurídicas, Facultad de Derecho, 2010, t. I, pp. 10 y 11. 
Este libro forma parte del acervo de la Biblioteca Jurídica Virtual del Instituto de Investigaciones Jurídicas de la UNAM

participación ciudadana en el control de la actividad financiera del Estado, el cual guarda estrecha vinculación con el respeto a los derechos humanos. Con este nuevo Sistema, las auditorías de desempeño que realice la ASF, ya no sólo estarán encaminadas a mejorar los resultados, la eficacia, la eficiencia y la economía de las acciones de cualquier orden de gobierno, sino también a verificar la progresividad de los derechos humanos mediante la gestión pública.

\section{El Comité de Participación Ciudadana}

Con la reforma al artículo 113 de la CPEUM, publicada en el $D O F$ el 27 de mayo de 2015 se crea el Sistema Nacional Anticorrupción, el cual es la instancia de coordinación entre las autoridades de todos los órdenes de gobierno competentes en la prevención, detección y sanción de responsabilidades administrativas y hechos de corrupción, así como en la fiscalización y control de recursos públicos.

Dentro de este nuevo Sistema habrá un Comité de Participación Ciudadana que deberá integrarse por cinco ciudadanos que se hayan destacado por su contribución a la transparencia, la rendición de cuentas o el combate a la corrupción, y cuyo objetivo es ser la instancia de vinculación con las organizaciones sociales y académicas relacionadas con las materias del Sistema Nacional Anticorrupción, artículo 15, Ley General del Sistema Nacional Anticorrupción (LGSNA).

El Comité de Participación Ciudadana tiene entre otras facultades y a lo que aquí interesa:

i) Proponer al Comité Coordinador, la instancia encargada de la coordinación y eficacia del Sistema Nacional Anticorrupción, a través de su participación en la Comisión Ejecutiva, mecanismos para que la sociedad participe en la prevención y denuncia de faltas administrativas y hechos de corrupción; ii) Llevar un registro voluntario de las organizaciones de la sociedad civil que deseen colaborar de manera coordinada con el Comité de Participación Ciudadana para establecer una red de participación ciudadana, y iii) Proponer reglas y procedimientos mediante los cuales se recibirán las peticiones, solicitudes y denuncias fundadas y motivadas que la sociedad civil pretenda hacer llegar a la ASF, así como a las entidades de fiscalización superiores locales (artículo 21, fracciones VIII, IX, y XII, respectivamente, de la LGSNA).

De lo anterior se desprende que el Comité de Participación Ciudadana no va a ser una instancia más de persecución de servidores públicos corrup- 
Este libro forma parte del acervo de la Biblioteca Jurídica Virtual del Instituto de Investigaciones Jurídicas de la UNAM

tos, para eso ya existen el órgano interno de control y el órgano externo de control, ni servirá como una instancia de consulta popular o algún otro medio que ya estudiamos, sino que va a acompañar y sugerir al Comité Coordinador sobre los mecanismos que pueden evitar las causas que generan la corrupción, ayudándose para esto de las opiniones vertidas desde la participación ciudadana. Es decir, va existir un flujo de información entre la ciudadanía y el Comité de Participación, del que derivarán propuestas que el mismo Comité deberá proponer en el seno del Sistema Nacional Anticorrupción y que pueden ser, por ejemplo, la adopción de medidas para atemperar la corrupción. En este sentido, es de suma importancia la participación de la ciudadanía a través de este medio, pues de ella depende en gran medida que el Sistema Nacional Anticorrupción adopte las medidas necesarias para alejar y prevenir la corrupción que se da con motivo del mal manejo de los recursos públicos y de esta forma cuidar y hacer respetar los derechos humanos de los ciudadanos.

En este contexto, también es importante señalar que las propuestas ciudadanas a través de este medio no son vinculantes. En todo caso, si se detecta algún hecho público de corrupción, el Comité de Participación puede solicitarle al Comité Coordinador que emita un exhorto al ente público involucrado para que aclare dicha situación (artículo 23, LGSNA). Asimismo, las recomendaciones que emita el Comité Coordinador a los entes públicos, a través del informe anual que rinda éste, tampoco son vinculantes.

En definitiva, habrá que esperar el entusiasmo con el que la ciudadanía reciba esta nueva forma de participación, pero también la misma sociedad se encontrará expectante de los resultados que arroje el trabajo del Comité de Participación. Al ciudadano de a pie le interesa que sus propuestas y que el ejercicio de sus derechos humanos sea resguardado y respetado. Y este será el único parámetro, desde el punto de vista ciudadano, con el cual le otorgará la calificación aprobatoria o reprobatoria de la operación del Sistema Nacional Anticorrupción.

\section{La Contraloría Social}

La Contraloría Social a que hace referencia la Ley de Fiscalización y Rendición de Cuentas de la Federación (LFRCF), no es un órgano ni tiene estructura para cumplir sus fines, sino simplemente es el nombre que la ley le da al mecanismo mediante el cual la sociedad civil vigila el desempeño de los servidores públicos de forma general. Es un mecanismo de vigilancia social que no busca sustituir las funciones de revisión y vigilancia de ninguno 
Este libro forma parte del acervo de la Biblioteca Jurídica Virtual del Instituto de Investigaciones Jurídicas de la UNAM

de los órganos exprofesamente establecidos para tal efecto, sino es una vía para que el ciudadano se sienta parte, mediante su colaboración, de estar participando en las decisiones públicas del gobierno.

La Contraloría Social, como mecanismo y no como institución se puede definir

...como el conjunto de acciones que realiza la ciudadanía de manera individual u organizada para participar activamente en la vigilancia y control de las acciones de gobierno, y con ello elevar el cumplimiento de los compromisos de las entidades de los tres órdenes de gobierno, mejorar la credibilidad y confianza de la sociedad en la administración pública, así como la percepción acerca de la corrupción y opacidad en los programas a cargo de instituciones de gobierno. ${ }^{21}$

Esta figura o mecanismo ya existía en la abrogada LFRCF de 29 de mayo de 2009. Con la reforma en materia de corrupción, lo único que se hizo fue abrir el abanico de posibilidades para la presentación de peticiones, solicitudes o denuncias de la ciudadanía, incluyendo no sólo a la Comisión como receptora de las mismas, sino también al Comité de Participación Ciudadana según se analizó en el apartado precedente.

Asimismo, se modificó el órgano que recibirá las opiniones, solicitudes y denuncias de los ciudadanos respecto de la actividad de la ASF. Antes se hacían ante la misma ASF, ahora se hacen ante la Unidad de Evaluación y Control que actúa como un ente controlador de la ASF.

Sobre este apartado, sólo habrá que hacer mención que todas esas opiniones, solicitudes, denuncias o peticiones que se realizan ante el Comité de Participación Ciudadana y ante la ASF, pueden o no ser tomadas en cuenta para la realización del programa anual de auditorías que realiza la ASF el cual debe ser publicado en el DOF. Esto implica dos cosas: no son vinculantes y las mismas, de no ser desechadas por los órganos facultados, surten sus efectos después de terminado el ejercicio fiscal, por tanto son un medio indirecto de control ex post.

\section{La denuncia ciudadana y los principios de anualidad y posterioridad}

Uno de los reclamos sociales más enérgicos en la discusión de la reforma en materia anticorrupción, fue la eliminación de los principios de anualidad y posterioridad en la revisión de las cuentas públicas, a efecto de que la

21 Definición obtenida el 22 de octubre de 2016 del documento disponible en: http:// wrere.contraloriasocial.unach.mx. 
Este libro forma parte del acervo de la Biblioteca Jurídica Virtual del Instituto de Investigaciones Jurídicas de la UNAM

ASF pudiera fiscalizar en tiempo real los presuntos desvíos de fondos públicos. Estos principios, que a mi gusto son en realidad una limitante en la acción fiscalizadora, impedían al órgano externo de control revisar el uso de los recursos públicos durante el ejercicio fiscal. De tal suerte que toda revisión del ejercicio fiscal concluido se hacía de forma posterior sin posibilidad de auditar de forma inmediata el ejercicio de recursos y cuyos resultados sobre dicho ejercicio se ofrecían dos o casi tres años después de conformidad con los plazos constitucionales.

La reforma constitucional en materia de Combate a la Corrupción, publicada en el $D O F$ el 27 de mayo de 2015, eliminó la referencia literal a dichos principios en el párrafo cuarto de la fracción I del artículo 79, pero los siguió conservando de facto, pues en el caso del de "posterioridad", se mantuvo la entrada de la fracción I del artículo citado que dice textualmente: "La Auditoría Superior de la Federación tendrá a su cargo: I. Fiscalizar en forma posterior los ingresos, egresos y deuda...". En el caso del "principio de anualidad", el mismo párrafo citado sujeta las observaciones y recomendaciones de la ASF, a que se realicen sólo respecto del ejercicio de recursos públicos de la cuenta pública en revisión y no de los ejercicios respecto de los cuales la ASF solicitó y revisó información de manera casuística y concreta. Por tanto, la observancia anual en la revisión del gasto sigue vigente. ${ }^{22}$ La reforma en este sentido quedó corta.

En cuanto a la denuncia ciudadana, que guarda estrecha vinculación con ambos principios, principalmente con el de posterioridad, la reforma al párrafo quinto de la fracción I del artículo 79 de la CPEUM quedó de la siguiente manera:

Sin perjuicio de lo previsto en el párrafo anterior, en las situaciones que determine la Ley, derivado de denuncias, la Auditoría Superior de la Federación, previa autorización de su Titular, podrá revisar durante el ejercicio fiscal en curso a las entidades fiscalizadas, así como respecto de ejercicios anteriores.

22 A mi juicio, la permanencia de facto de este principio inhibe y anula el sentido del nuevo párrafo tercero del artículo 79, y permite a la ASF iniciar el proceso de fiscalización a partir del primer día hábil del ejercicio fiscal siguiente, debido a que la segunda parte de dicho párrafo concluye señalando que las observaciones o recomendaciones que en su caso realice la ASF, deberán referirse a la información definitiva presentada en la cuenta pública. Contribuye a la inocuidad del párrafo señalado, la sujeción de la práctica de la auditoría a que se publique en el Diario Oficial de la Federación, la última semana del ejercicio fiscal a auditar, el plan previo de auditorías. Los informes individuales que ahora con la reforma anticorrupción puede entregar la ASF en los meses de junio y octubre, también surten efectos hasta que se presente la información definitiva en la cuenta pública. 
Este libro forma parte del acervo de la Biblioteca Jurídica Virtual del Instituto de Investigaciones Jurídicas de la UNAM

Es un avance - a mi modo de ver- que ahora la ASF, derivado de denuncias, pueda revisar directamente el ejercicio fiscal en curso de las entidades fiscalizadas, ya que antes de la reforma sólo podía solicitar información a dichas entidades, dándoles oportunidad de presentarla dentro de los 30 días hábiles siguientes a la solicitud, retrasando con ello la oportunidad en la fiscalización. Actualmente, no existe un plazo constitucional, pero el artículo 9o. de la LFRCF faculta a la ASF a establecer el mismo, que no será inferior a diez días hábiles ni mayor a quince días hábiles contados a partir del día siguiente a que haya surtido efectos la notificación correspondiente, con lo cual se acelera la revisión del supuesto desvío de fondos públicos.

También fue un acierto ampliar los casos para la procedencia de la presentación de denuncias, pues en ley abrogada estaban mucho más acotados, por ejemplo, la denuncia por daño patrimonial a la Hacienda Pública federal o al patrimonio de los entes públicos y de las entidades paraestatales federales, tenía que ser por un monto superior a cien mil veces el salario mínimo diario general vigente en el Distrito Federal, de tal forma que la procedencia de la denuncia por montos menores a ese resultado no era atendida, y así sucesivamente.

Lo que no queda preciso en la CPEUM ni en la respectiva ley reglamentaria, es si la revisión de ejercicios anteriores derivado de una denuncia en los que se encuentren irregularidades en el ejercicio del gasto, provoca la apertura de la cuenta pública del o de los ejercicios revisados. Aunque el inicio del último párrafo de la fracción I, del artículo 79 constitucional establece un "sin perjuicio de lo previsto en el párrafo anterior", lo que hace suponer que aun en estos casos, no está permitido abrir nuevamente la cuenta pública de ejercicios pasados y cerrados. Si este último es el sentido de nuestra Constitución, se confirma que el ámbito temporal de la denuncia se circunscribe solo al ejercicio fiscal vigente.

Queda saber si en este último caso, se generan consecuencias jurídicas inmediatas, en virtud de que la auditoría realizada por la ASF por denuncia deberá rendirse en un informe que presenta la ASF a la Cámara de Diputados a más tardar a los diez días hábiles posteriores a la conclusión de la auditoría (artículo 65, LFRCF), pero la ley no establece, primero, un plazo a la ASF para realizar la auditoría en los casos derivados de denuncia (¿debiera hacerlo?), y segundo, un plazo para la Cámara de Diputados a efecto de pronunciarse respecto de este tipo de auditoría - pues los informes casi siempre se archivan en un cajón - con lo cual, el tiempo que dure este procedimiento puede llegar a no ser una fiscalización en tiempo real ya que los efectos jurídicos no son en tiempo real, considerando además que los informes que rinde la ASF a la Cámara de Diputados en materia de denuncias son se- 
Este libro forma parte del acervo de la Biblioteca Jurídica Virtual del Instituto de Investigaciones Jurídicas de la UNAM

mestrales, según el artículo 38 de la LFRGF, y que la información solicitada por la ASF del ejercicio en curso sirve exclusivamente para los trabajos de planeación de auditorías que se realizan anualmente.

Con el esquema anterior, la denuncia ciudadana, que representa un bastión del cuidado y resguardo de los derechos humanos de la población, se ve limitada por la CPEUM y por la ley reglamentaria, haciendo su ejercicio un largo procedimiento sin efectos jurídicos inmediatos y sin respuesta efectiva para los denunciantes. Habrá que esperar las consecuencias jurídicas derivadas de la denuncia ciudadana, pero su futuro se ve nebuloso. Hace falta que las aportaciones de la ciudadanía, sobre todo cuando versan sobre la protección de los derechos humanos, vinculen con mayor enjundia a las autoridades infractoras y que los órganos de control no se vean limitados para controlar el gasto y la corrupción de los servidores públicos.

\section{GONCLUSIÓN}

La materialización del ciclo presupuestario recae en el documento jurídico/contable llamado Presupuesto de Egresos; éste es, en forma sintética, un proceso de asignación de recursos públicos. Designación que debe tomar en cuenta a los diferentes receptores del mismo y las finalidades que el Estado persigue. Pero para que el Presupuesto sea realmente democrático, no solamente habrá de considerar la asignación de partidas basada en los resultados de los programas gubernamentales (ardua tarea, por cierto), sino también en que el mismo sea receptivo a las necesidades de los ciudadanos. En este proceso la participación ciudadana y los demás medios democráticos de participación son fundamentales para lograrlo. Sin embargo, y a fin de cuentas, es responsabilidad del gobierno y de los parlamentos, considerar e incluir las propuestas ciudadanas. Los derechos humanos se promueven y se garantizan, es obligación del Estado, pero frente a una violación de ellos, se ejerce una acción para protegerlos y hacerlos respetar. Corresponde al Estado, entonces, proporcionar los medios fundamentalmente presupuestarios, para resguardarlos y hacerlos valer, sin que el cuidado de estos se sujete a condición alguna ni que el gobierno alegue la falta de recursos públicos so pena de evadir la responsabilidad constitucional que le mandata el artículo 1o. de nuestra carta magna. 
Este libro forma parte del acervo de la Biblioteca Jurídica Virtual del Instituto de Investigaciones Jurídicas de la UNAM

\section{BIBLIOGRAFÍA}

Allen, Schick, "Redemocratizar los presupuestos", Los presupuestos del Estado: transparencia y democracia, España, Fundación Modernización de España, 2003.

Alvarado Esquivel, Miguel de Jesús, "Puntos críticos en la ejecución de las sentencias de amparo", La ciencia del derecho procesal constitucional. Estudios en homenaje a Héctor Fix-Zamudio, México, UNAM-Marcial Pons, 2008.

Alvarado Esquivel, Miguel de Jesús, "Un extraño ataque a la ejecutorias de amparo: la insuficiencia presupuestaria de las autoridades administrativas", en Nava Escudero, Óscar y Ortega Maldonado, Juan Manuel (coords.), Derecho presupuestario. Temas selectos, México, Porrúa, 2006.

Castro Estrada, Álvaro, Responsabilidad patrimonial del Estado, 3a. ed., México, Porrúa, 2006.

CORTI, Horacio, Derecho constitucional presupuestario, 2a. ed., Buenos Aires, Abeledo-Perrot, 2011.

FIX-ZAMUDIO, Héctor, "Aspectos contemporáneos de la justicia administrativa", Estudios jurídicos en homenaje a Alfonso Nava Negrete. Administración pública contemporánea. Derecho, política y justicia, México, Porrúa-UNAM, Instituto de Investigaciones Jurídicas, Facultad de Derecho, 2010.

García DE EnTERría, Eduardo, y FERnández, Tomás-Ramón, Curso de derecho administrativo, 13a. ed., Madrid, Cívitas, 2006.

Gimeno Sendra, Vicente, Constitución y proceso, Madrid, Tecnos, 1998.

Hallivis Pelayo, Manuel Luciano, "Evolución y perspectivas del contencioso administrativo en México. Tecnología y tutela jurisdiccional", Estudios jurídicos en homenaje a Alfonso Nava Negrete. Administración pública contemporánea. Derecho, política y justicia, México, Porrúa-UNAM, Instituto de Investigaciones Jurídicas, Facultad de Derecho, 2010.

Nava Escudero, Óscar, Derecho presupuestario mexicano, México, Porrúa, 2014.

NAVA Escudero, Óscar, El Estado deudor frente a sus acreedores. (La exigibilidad de las obligaciones de la hacienda pública), Madrid, Instituto de Estudios FiscalesMinisterio de Economía y Hacienda, 2006.

Oliva SANTOS, Andrés, "La demolición de la administración de justicia en la futura constitución de 1978", Comunicación a la XIV reunión de profesores de derecho procesal de las universidades del Estado español, España, s.e., 1978.

VACAS GARCíA-ALÓs, Luis, Ética pública y participación ciudadana en el control de las cuentas públicas, España, REUS, 2015. 
Este libro forma parte del acervo de la Biblioteca Jurídica Virtual del Instituto de Investigaciones Jurídicas de la UNAM

\title{
LOS PREGEDENTES DE LOS JUEGES EN LA DISCUSIÓN SOBRE EL PRESUPUESTO PÚBLICO Y DEREGHOS HUMANOS EN MÉXICO
}

\section{Roberto MARTINEZ REGINO*}

\begin{abstract}
SUMARIO: I. Introducción. II. La situación actual de las políticas públicas en México. III. La inminente e inseparable relación entre el presupuesto público y los derechos humanos en México. IV. Los juzgadores y el control del presupuesto público en México. V. Conclusiones. VI. Fuentes de información.
\end{abstract}

\section{INTRODUCGIÓN}

La globalización como efecto y como causa ha permeado en los Estados y ha traído como consecuencia que sus instituciones cambien o deban modificarse atendiendo a nuevas formas de pensar y ajustar el comportamiento humano al marco referencial del Estado de derecho.

Los derechos humanos positivizados en los actuales ordenamientos, han traído consigo criterios o estándares de satisfacción por los órganos públicos, lo cual implica que deban ser efectivos los derechos de las personas, atendiendo a aquellos cuyo deber depende de acciones públicas.

La situación actual del sistema jurídico mexicano ha colocado como eje central a los derechos fundamentales, lo que implica que todo comportamiento de autoridades deba ajustarse a aquellos.

En este contexto, resulta imposible negar la inminente relación entre derechos humanos y el presupuesto público, pues ambos dependen de manera simétrica, y deben encontrar objetivos claros al mismo ritmo.

Sin embargo, la realidad muestra una serie de dolencias institucionales que se vuelven obstáculos para lograr la efectividad de los derechos fundamentales, si a las políticas que requieren desplegarse no se les asignan en

* Doctor en derecho y globalización por la Facultad de Derecho y Ciencias Sociales de la Universidad Autónoma del Estado de Morelos. Correo electrónico: regino_ct3@hotmail.com. 
Este libro forma parte del acervo de la Biblioteca Jurídica Virtual del Instituto de Investigaciones Jurídicas de la UNAM

forma correcta recursos económicos. Mayor aún, si se pretende impugnar una deficiente asignación presupuestaria y existen tropiezos jurídicos debido al rezago en la actualización de tal institución que impide lograr una equitativa distribución o redistribución de recursos económicos.

Es en esta problemática objeto de estudio en la que no puede omitirse la estrecha relación, indisoluble, entre diversas materias del derecho inmersas y que coadyuvan a la definición de soluciones, esto es así, pues mientras los derechos humanos positivizados en la norma jurídica requieren efectividad y con ello actividad estatal, por medio del derecho administrativo se regula la organización de las acciones administrativas a desplegar para satisfacer los primeros.

No obstante aquel orden administrativo requiere de recursos económicos, ello obliga al propio Estado a realizar diversas actividades financieras a fin de contar con dinero y cumplir los objetivos que le dan existencia, para ello se auxilia del derecho financiero para estudiar temas como son: ${ }^{1}$ planeación económica, gestión de bienes de dominio público y de dominio privado del Estado, los ingresos que obtiene, el gasto público, así como la fiscalización y control de los anteriores.

En tal sentido puede advertirse los recursos económicos del país terminan siendo asignados a través del Presupuesto de Egresos de la Federación (PEF), hoy motivo de estudio del derecho constitucional presupuestario.

Lo anterior permite asimilar la existencia del deber del Estado de satisfacer los derechos humanos a través de acciones positivas, lo que implica también, asignar recursos suficientes con las cuales pueda organizar y desarrollar sus actividades que permitan se cumplan en la realidad los derechos fundamentales.

De esta manera, todo tipo de acto público ya sea dentro del ámbito del derecho administrativo, derecho financiero o derecho constitucional presupuestal, no pueden ser contrarios a los derechos fundamentales, pues por la trascendencia en el tema y las aportaciones que permean entre una y otra, sin demeritar otras ramas jurídicas, constituyen, lo que para Fritz Werner lo fue el derecho administrativo en Alemania, ${ }^{2}$ el "derecho constitucional de lo concreto o concretizado, atendiendo que las personas

1 Ortega Maldonado, Juan Manuel, Lecciones de derecho fiscal, México, 2a. ed., Porrúa, 2012, p. 3.

$2 \mathrm{Al}$ respecto puede consultarse Ibler Martin, "Derecho administrativo como derecho constitucional concretizado”, Respublica, Alemania, 2010, núm. 2, pp. 35-37; así como Christian Röhl, Hans, "El derecho administrativo como ciencia" en Santofimio Gamboa, Jaime Orlando et al. (eds.), Perspectivas de una reforma. Estudios de derecho administrativo a partir de la obra de Eberhard Schmidt-Assmann, Bogotá, Universidad Externado de Colombia, 2016, pp. 23-26. 
Este libro forma parte del acervo de la Biblioteca Jurídica Virtual del Instituto de Investigaciones Jurídicas de la UNAM

se relacionan con los órganos públicos y se vuelve necesario hacer más fluidas y satisfactorias las prestaciones de servicios que cumplan derechos humanos".

Es por ello que se pretende mostrar las causas que imperan para que el Estado sea eficaz en el logro de los objetivos que le dan existencia, así, posteriormente se podrá dimensionar la relación existente entre derechos humanos y el presupuesto público, y reflexionar respecto del desarrollo de los precedentes emitidos atendiendo a esta relación, ante una realidad que permite entender que ha iniciado bajo un nuevo impulso la exigibilidad judicial de derechos humanos y el impulso de políticas presupuestarias.

\section{LA SITUACIÓN ACTUAL DE LAS POLÍTICAS PÚBLICAS EN MÉXICO}

La realidad advierte la existencia de diversas necesidades sociales crecientes en diferentes latitudes del mundo que requieren atención y prioridad, algunas de ellas por el propio Estado-nación, otras más a través de la colaboración internacional.

En la realidad mexicana donde impera una población que asciende a 112,336,538 millones de personas ${ }^{3}$ de la cual 55.3 millones se encuentran en pobreza, ${ }^{4}$ apremian necesidades como: la protección a la vida, el acceso al agua, a la salud, a la vivienda, a la educación, a la seguridad pública, al trabajo, a la seguridad social, a la alimentación, entre otros. Es por ello que toma especial relevancia las actividades desempeñadas por el Estado o políticas públicas, entendidas como: ${ }^{5}$

...instrumentos de administración o gestión gubernamental cuyo propósito es planear, programar y concretar acciones de gobierno que, en el caso de los derechos humanos, permitirían plasmar los criterios ideales de justicia, principios o normas jurídicas - ciertamente abstractos - en que suelen elaborarse los derechos. Las políticas públicas no son otra cosa que objetivos públicos compartidos, con el alcance de programas de acción orientados a la consecución de fines sociales valiosos.

3 Instituto Nacional de Estadística y Geografía, "México en cifras", disponible en: http://wrere.beta.inegi.org.mx/app/areasgeograficas/, consultado el lo. de febrero de 2017.

4 Consejo Nacional de Evaluación de la Política de Desarrollo Social, "Medición de la pobreza", disponible en: http://wrwre.coneval.org.mx/Medicion/MP/Paginas/Pobreza_2014.aspx, consultado el 1o. de febrero de 2017.

5 Álvarez Ledezma, Mario I., "Derechos humanos y políticas públicas" en Rossi, Andrea et al. (coords.), Políticas publicas y derechos humanos en México, México, ITESM, 2010, p. 121. 
Este libro forma parte del acervo de la Biblioteca Jurídica Virtual del Instituto de Investigaciones Jurídicas de la UNAM

Por tanto, se trata de instrumentos cuyas acciones vinculan los problemas públicos de acuerdo a la realidad social y la solución de aquellos con perspectiva de derechos humanos. No obstante lo anterior, al actual Estado contemporáneo se le cuestiona sobre la fragmentación y contrariedad en sus políticas ya sea en los cuerpos normativos, programas y proyectos que disminuyen capacidad y eficiencia social, aun cuando posea la mejor voluntad y dedicación, pues sus funciones para la satisfacción de problemas públicos están desarticuladas.

Lo anterior atiende a diversas causas notorias en el país, divididas en cinco temas pendientes: ${ }^{6}$

1. Planeación nacional.

2. Responsabilidad y vinculación de los órganos públicos.

3. La aclaración de la verdadera naturaleza jurídica del gasto público y su asignación presupuestaria.

4. La rendición de cuentas y transparencia de las políticas públicas implementadas.

5. La participación de la sociedad en el diseño y ejecución de las políticas públicas que satisfagan derechos fundamentales.

Lo anterior es así, pues no existe una planeación pública de acuerdo a un modelo de desarrollo nacional, políticas públicas de largo plazo, pues saltan a la vista diversas incoherencias derivadas del Sistema Nacional de Planeación Democrática y de la ley de planeación, al existir planes sexenales y rendición de cuentas anuales, desarticulación de los tres órdenes de gobierno a falta de una sola visión así como escasos mecanismos de participación social en las políticas públicas.

Es sabido que el Plan Nacional de Desarrollo requiere del gasto público, para cumplir sus objetivos, empero, aquel no es vinculante al H. Congreso de la Unión, dejando sólo responsabilidad al Ejecutivo, sin duda se necesita la corresponsabilidad del ente legislativo al respecto.

Atendiendo a lo anterior, el presupuesto público es una política pública, un "documento clave y un proceso esencial para manejar la riqueza finan-

6 Al respecto puede consultarse, Vásquez Colmenares G., Pedro, "La planeación, el presupuesto y las políticas públicas", en Méndez, José Luis (coord.), Los grandes problemas de México, México, El Colegio de México, 2010, t. XIII "Políticas Públicas"; Mejorada Fernández Sánchez, Cristina, "La participación ciudadana", en Garza, Gustavo y Schteingart, Martha (coords.), Los grandes problemas de México, México, El Colegio de México, 2010, t. II "Desarrollo urbano y regional"; Tapia Álvarez, Mónica, "Organizaciones de la sociedad civil y políticas públicas”, en Méndez, José Luis (coord.), Los grandes problemas de México, México, El Colegio de México, 2010, t. XIII "Políticas Públicas". 
Este libro forma parte del acervo de la Biblioteca Jurídica Virtual del Instituto de Investigaciones Jurídicas de la UNAM

ciera y de recursos de una sociedad"7 conocido en México como Presupuesto de Egresos de la Federación, que a falta de disposición expresa en la Constitución Política de los Estados Unidos Mexicanos (CPEUM), la Suprema Corte de Justicia de la Nación vía jurisprudencia, ha indicado que carece del carácter de ley, asignándole el de acto administrativo lo que impide su impugnación a través de las garantías existentes en el país. Sin duda, dicho precedente debe ser superado.

Hoy en día el sistema de rendición de cuentas no posee un mecanismo de evaluación del desempeño público, de forma que el ciudadano conozca cómo inicia y cómo termina una administración, y determine si las políticas públicas han cumplido su objetivo. Por otra parte, se vuelve importante la actualización de la Ley Federal de Transparencia y Acceso a la Información Gubernamental a fin de que las personas puedan obtener la información que les permita participar en la planeación del país.

Finalmente, se vuelve imprescindible institucionalizar los procesos de participación ciudadana deliberativa, mayor conciencia de los representantes populares del deber de cumplir las necesidades consensadas, así como mayor información, responsabilidad y compromiso de la participación de la sociedad civil.

Como puede apreciarse, son amplios y complejos los factores que influyen en el cumplimiento de los objetivos del Estado orden social y protección de los derechos humanos. Como es de esperarse, cada órgano público tiene una función específica dentro del sistema jurídico mexicano, y debe brindar bienes y servicios en calidad y cobertura, pero cuando ello no se logra por diversos problemas entre los que se han mencionado anteriormente, se les afecta a las personas en sus derechos que dependen de las prestaciones que deben proporcionar los entes públicos.

Resulta claro que las políticas públicas son un instrumento para la efectividad de los derechos humanos, legitimar el poder y la realización de la justicia. Y al ser los recursos económicos limitados, las políticas públicas eficientes deben equilibrar los valores de los derechos de las personas y la eficacia del PEF.

Indudablemente, no existe mayor legitimación ante la sociedad por representantes públicos que a través de logros, éxitos y resultados ante las crecientes y apremiantes necesidades sociales, empero, cuando las personas no perciben tal satisfacción o respuesta por parte de los órganos políticos tradicionales es común que acudan a la sede judicial para controvertir la política

7 Blyberg, Ann, "El caso de la asignación incorrecta: derechos económicos y sociales y el trabajo presupuestario", Sur. Revista Internacional de Derechos Humanos, Brasil, vol. 6, núm. 11, diciembre de 2009, semestral, p. 150. 
Este libro forma parte del acervo de la Biblioteca Jurídica Virtual del Instituto de Investigaciones Jurídicas de la UNAM

pública, ausente o deficiente con la que se pretende satisfacer sus derechos fundamentales. Si bien, en la gran mayoría de los Estados-nación acontece la judicialización de la política para impulsar derechos humanos, es en países específicos donde tales decisiones se impregna de alcance presupuestal en forma más puntual; Argentina, Colombia, Brasil, Estados Unidos de Norteamérica, India y Sudáfrica.

Por ello, es de trascendental relevancia dimensionar la caracterización de dicha binomio, ante el punto de partida normativo del 2011; México comienza a vivir en relación a países cuyo marco de referencia ya tienen camino recorrido.

\section{LA INMINENTE E INSEPARABLE RELACIÓN ENTRE EL PRESUPUESTO PÚBLICO Y LOS DERECHOS HUMANOS EN MÉXICO}

A través de la intervención de órganos públicos como es el ejecutivo y legislativo es posible reconocer nuevos derechos o expandir los ya existentes, ello implica que ya se ha hecho un análisis del impacto social, político y hasta económico.

No existe duda, emerge como nuevo paradigma en la actualidad la estrecha vinculación entre el presupuesto público y los derechos fundamentales, ambas instituciones imprescindibles del sistema jurídico mexicano. Pues el primero actúa como instrumento con el que se distribuye la riqueza del país a los diversos órganos públicos para que realicen sus actividades a favor de las personas, los segundos dependen del primero pues los derechos fundamentales cuyo cumplimiento corresponde al Estado, deben ser satisfechos a través de las políticas que desplegaran los entes públicos.

No basta reconocer derechos fundamentales, sino también asignarles recursos económicos a las políticas públicas que habrán de efectivizar a los primeros, por ello, capta nuestra atención el PEF, porque a través de esta institución el Estado puede financiar bienes y servicios para las personas.

En forma reciente, frente a las innumerables reformas de nuestro máximo ordenamiento en el país, resalta la de derechos humanos, a través de la cual, al reconocerse a aquellos derechos fundamentales contenidos en tratados internacionales en la materia, igual jerarquía que aquellos contenidos en la CPEUM, hace que los derechos de las personas se coloquen en el eje central del sistema jurídico mexicano.

Atendiendo a lo anterior, el Estado posee una serie de deberes derivados del contenido de todos los tratados internacionales firmados y ratificados en materia de derechos humanos, de forma que toda actuación de los 
Este libro forma parte del acervo de la Biblioteca Jurídica Virtual del Instituto de Investigaciones Jurídicas de la UNAM

órganos públicos debe sujetarse no sólo a los parámetros constitucionales - como son las características de los derechos fundamentales: universalidad, interdependencia, indivisibilidad y progresividad $-{ }^{8}$ sino también a los estándares internacionales como: ${ }^{9}$ uso máximo de recursos, progresividad, medidas adecuadas, recursos efectivos, tomar en cuenta el desarrollo del pais, la no discriminación, niveles minimos de satisfacción de los derechos y protección de miembros vulnerables de la sociedad en tiempos graves de recursos.

Como se podrá apreciar, los derechos humanos pueden ser violados a raíz de "una distribución desigual de la riqueza y recursos de la sociedad", ${ }_{10}$ esto es, si la H. Cámara de Diputados de quien depende la aprobación del PEF de manera anual, decide no asignar, o reducir en forma injustificada, recursos económicos a un ente público, este último puede alterarse en las actividades que debe brindar a la sociedad, quedando afectados los derechos de la propia sociedad, reconocidos en los amplios ordenamientos vigentes en el país. Asimismo, no puede descartarse situaciones donde una vez asignados recursos económicos, el ente público que los recibió no desea ejecutarlos o los destina a un fin distinto al que le corresponde, alterando igualmente las actividades en calidad y cobertura como debiera hacia las personas.

En todo Estado los recursos económicos siempre serán limitados frente a las crecientes necesidades que se tienen, pero no puede sólo esgrimirse escasez de dinero para que a través de acciones u omisiones se apliquen medidas regresivas o discriminatorias a los derechos de las personas, incumpliendo el imperio o fuerza del contenido de los tratados internacionales. $\mathrm{Al}$ respecto, se encuentran referencias que indican una serie de acciones previas a aplicar medidas regresivas, como son: ${ }^{11}$

8 Véase artículo 1o. de la Constitución Política de los Estados Unidos Mexicanos.

9 Atendiendo a ordenamientos internacionales como la Declaración Universal de los Derechos Humanos, Pacto Internacional de Derechos Civiles y Políticos, Pacto Internacional de Derechos Económicos, Sociales y Culturales, Observación General núm. 3, del Comité de Derechos Humanos del Pacto Internacional de Derechos, Económicos, Sociales y Culturales, Observación General núm. 9, del Comité de Derechos Humanos del Pacto Internacional de Derechos Económicos, Sociales y Culturales, Convención Americana de Derechos Humanos, Protocolo Adicional a la Convención Americana sobre Derechos Humanos en materia de derechos económicos, sociales y culturales, "Protocolo de San Salvador", documento de avance sobre las normas para la confección de los informes periódicos previstos en el artículo 19 del Protocolo de San Salvador, Declaración E/C. 12/2007/1 del Comité de Derechos Económicos, Sociales y Culturales del 21 de septiembre de 2007, entre otros.

10 Blyberg, Ann, op. cit., p. 150

11 Artículo 10 de la Declaración E/C. 12/2007/1 del Comité de Derechos Económicos, Sociales y Culturales del 21 de septiembre de 2007. 
Este libro forma parte del acervo de la Biblioteca Jurídica Virtual del Instituto de Investigaciones Jurídicas de la UNAM

a) El nivel de desarrollo del país.

b) La gravedad de la presunta infracción, teniendo particularmente en cuenta si la situación afecta el disfrute de los derechos básicos enunciados en el Pacto.

c) La situación económica del país en ese momento, teniendo particularmente en cuenta si el país atraviesa un periodo de recesión económica.

d) La existencia de otras necesidades importantes que el Estado parte deba satisfacer con los recursos limitados de que dispone; por ejemplo, debido a un reciente desastre natural o a un reciente conflicto armado interno o internacional.

e) Si el Estado parte trató de encontrar opciones de bajo costo.

f) Si el Estado parte recabó cooperación y asistencia de la comunidad internacional o rechazó sin motivos suficientes los recursos ofrecidos por la comunidad internacional para la aplicación de lo dispuesto en el Pacto.

Puede identificarse entonces que el Estado, al tomar medidas negativas sin la debida justificación, viola derechos de las personas dado que los bienes y servicios que proporcionan los órganos públicos no pueden seguir siendo prestados ante la escasez de dinero necesario para financiar aquellos. Ello nos permite afirmar, que no puede aplicarse la excepción como regla general para adoptar medidas regresivas o discriminatorias respecto a los derechos de las personas.

Se afirma entonces, no hay derechos humanos sin presupuesto público, pues todos aquellos derechos fundamentales cuyo cumplimiento depende del Estado deben satisfacerse por este último, pero para que ello ocurra, se necesita de asignación de recursos económicos, para proteger al menos el núcleo esencial del derecho respectivo.

Atendiendo a lo antes referido, existe la convicción que todos los derechos exigen protección legal y ya sea que se requiera del Estado como respuesta una dimensión prestacional o de abstención, se convierten en positivos, porque necesitan de financiamiento económico. Todos los derechos necesitan dinero, porque son "servicios sociales financiados por los contribuyentes y administrados por el Estado para mejorar el bienestar individual y colectivo". ${ }^{12}$

No obstante, por una parte se tiene una institución derivada de la reforma constitucional del 2011; el bloque de constitucionalidad en derechos

12 Holmes, Stephen y Sunstein, Cass R., El costo de los derechos. Por qué la libertad depende de los impuestos, trad. de Stella Mastrangelo, Argentina, Siglo XXI, 2011, p. 69. 
Este libro forma parte del acervo de la Biblioteca Jurídica Virtual del Instituto de Investigaciones Jurídicas de la UNAM

humanos,${ }^{13}$ innovadora en la materia que facilita la efectividad de los derechos fundamentales, por la composición normativa que la caracteriza, pero por otra, el presupuesto público, una institución que ha permanecido inerte en la actualización sobre nuevas formas en la que se debe atender su juridicidad.

Se trata pues de dos instrumentos necesarios para cumplir los objetivos del Estado, pero con distintas velocidades, pues aun cuando la primera pretenda cumplir los más ambiciosos objetivos a pasos agigantados, es frenado por la otra institución que se vuelve un ancla para los alcances de aquella, así como para impulsar políticas públicas basadas en derechos fundamentales.

\section{LOS JUZGADORES Y EL GONTROL DEL PRESUPUESTO PÚBLICO}

En México se ha transitado del concepto de democracia de tipo jacobino o procedimental, “...en el sentido de omnipotencia de la mayoría y, por tanto, de los poderes políticos representativos", ${ }^{14}$ por el de tipo sustancial " “..relativa no a quien se encuentra habilitado para decidir (la mayoría, desde luego), sino a qué cosa no es lícito decidir (o no decidir) a ninguna mayoría, ni siquiera por unanimidad", ${ }^{15}$ ha cambiado consigo el marco referencial normativo en el Estado, caracterizándose por un Estado de derecho constitucional y democrático. Atendiendo a lo anterior, se debe considerar el cambio de concepción que se viene gestando en el pensamiento de las sociedades del mundo de ya no considerar a la Constitución como un documento político sino jurídico, situaciones con el cual el Poder Judicial adquiere legitimidad por resultados.

La existencia del bloque de constitucionalidad de derechos humanos derivada de la reforma constitucional del 2011, modificó la jerarquía normativa suprema que en forma tradicional había conservado únicamente la CPEUM y su contenido.

Esto toma importancia debido a que si se considera al precedente de la SCJN que indica que la normatividad existente en el país consiste en:

$13 \mathrm{Al}$ respecto la doctrina lo ha definido como "normas y principios que, sin aparecer formalmente en el articulado del texto constitucional, son utilizados como parámetros del control de constitucionalidad de las leyes, por cuanto han sido normativamente integrados a la Constitución, por diversas vías y por mandato de la propia Constitución". Huerta Lara, Ma. Del Rosario, "El bloque de constitucionalidad y el nuevo juicio de amparo", Letras furídicas, México, núm. 26, julio-diciembre de 2012, p. 4.

14 Ferrajoli, Luigi, "Jurisdicción y democracia", en Carbonell, Miguel et al. (comps.), Fueces y derecho, 2a. ed., México, Porrúa, 2008, p. 105.

15 Ibidem, pp. 105 y 106. 
Este libro forma parte del acervo de la Biblioteca Jurídica Virtual del Instituto de Investigaciones Jurídicas de la UNAM

a) La Constitución federal, $b$ ) tratados internacionales, $c$ ) leyes generales, federales y locales ${ }^{16}$ adminiculado con los efectos de la reforma en materia de derechos humanos, los derechos de las personas contenidos en los tratados internacionales adquieren igual estatus que aquellos de contenido constitucional, y en todo caso el resto de la normatividad jerárquicamente inferior debe cumplir con aquellos. En tal sentido, si se busca cumplir los derechos fundamentales imperantes, ninguna ley, decreto, acto u omisión inferior derivado de toda autoridad, como lo es el PEF - de tercer grado normativopuede contradecir aquellos.

Ante este escenario, las personas identifican a la Constitución normativa, y al percatarse que el Estado incumple deberes como son derechos fundamentales, aunado a la falta de confianza en los órganos políticos tradicionales competente en la aprobación y aplicación de las políticas públicas, deciden a hacer exigibles los derechos inherentes a su persona ante los tribunales a través de las garantías existentes para “...desestabilizar... el equilibrio institucional perverso que bloquea el funcionamiento de la democracia y el cumplimiento de los derechos", ${ }^{17}$ y con ello, "reparar o sancionar judicialmente las lesiones de los derechos". ${ }^{18}$

Las nuevas formas de pensar la juridicidad de las instituciones del Estado, surgen con motivo del efecto y causa de la globalización. En tal sentido el presupuesto público, que había sido objeto de decisiones discrecionales por entes públicos, ante la nueva realidad social e internacional entra en crisis por la nueva forma de pensar su adaptación al derecho; ${ }^{19}$ la imposibilidad de hablar sólo de la intraestatalidad del gasto público vinculado a los derechos humanos, de sujetar la potestad legislativa al derecho y de la no judicialización a la participación del Poder Judicial en temas como de la justa distribución de la riqueza del país, es por ello, que se vuelve necesario discutir dicha institución desde una perspectiva de de-

16 Así lo indica la tesis P.IX/2007, Semanario Fudicial de la Federación de la Federación y su Gaceta, Novena Época, t. XXV, abril del 2007, p. 6.

17 Rodríguez Garavito, César y Rodríguez Franco, Diana, "Un giro en los estudios sobre derechos sociales: el impacto de los fallos judiciales y el caso del desplazamiento forzado en Colombia”, en Courtis, Christian y Ávila Santamaría, Ramiro (eds.), La protección judicial de los derechos sociales, Ecuador, Ministerio de Justicia y Derechos Humanos, 2009, p. 355.

18 Ferrajoli, Luigi, Derechos y garantías. La ley del más débil, 7a. ed., España, Trotta, 2010, p. 43.

19 Cfr. Corti, Horacio, "Las coordenadas claves de la discusión", mesa II, Seminario Internacional Derechos Humanos: Presupuesto Públicos y Control Judicial, México, UNAM, Instituto de Investigaciones Jurídicas, 4 de abril del 2011, disponible en: https://wrere.juridicas. unam.mx/videoteca/evento/seminario-internacional-derechos-humanos-presupuestos-publicos-y-controljudicial/2011-04-04/mesa-2-las-coordenadas-claves-de-la-discusion. 
Este libro forma parte del acervo de la Biblioteca Jurídica Virtual del Instituto de Investigaciones Jurídicas de la UNAM

rechos humanos no sólo para satisfacer estos últimos sino para anticipar tutelas de violaciones a derechos.

De la existencia de dos mecanismos en el país como el control de convencionalidad y constitucionalidad, ${ }^{20}$ permite entender que existen medios de exigibilidad judicial el primero atendiendo a que jueces locales y algunos federales - que no conocen por vía directa de control constitucional-, podrán inaplicar la norma si es contraria a la Constitución o a tratados internacionales en materia de derechos humanos y del segundo a través del uso del juicio de amparo, controversia constitucional y acción de inconstitucionalidad, con los cuales se puede declarar inconstitucional un acto, omisión o norma por ser contrario a la CPEUM o a tratados internacionales.

En este contexto al impugnarse el presupuesto público por las garantías antes referidas al controvertirse el contenido de aquel por una inequitativa distribución de los recursos económicos que afecta los derechos de las personas o de las autoridades, ha seguido el consecuente camino de precedentes:

\section{En relación a la naturaleza del presupuesto público}

El nuevo contexto social político que acontecía a finales del siglo pasado hizo posible que por primera vez se discutiera en sede judicial la política presupuestaria, lo que implicó retomar el tema que durante dos siglos de existencia del Estado sólo se había estudiado en el país en forma escasa por la doctrina.

Las decisiones de la Corte comenzarían estableciendo vía interpretación sobre la naturaleza que posee el presupuesto público. De esta manera, diferenció entre ley y acto administrativo: ${ }^{21}$

...mientras que la ley es una disposición de carácter general, abstracta e impersonal, el decreto es un acto particular, concreto e individual. Por otra parte, la generalidad del acto jurídico implica su permanencia después de su aplicación, de ahí que deba aplicarse cuantas veces se dé el supuesto previsto, sin distinción de persona. En cambio, la particularidad consiste en que el acto jurídico está dirigido a una situación concreta, y una vez aplicado, se extingue.

$20 \mathrm{Al}$ respecto puede consultarse la Tesis 1a./J. 18/2012 (10a.), Semanario Fudicial de la Federación y su Gaceta, Décima Época, t. I, diciembre de 2012, p. 420, asimismo, tesis P. LXVII/2011(9a.), Semanario Fudicial de la Federación y su Gaceta, Décima Época, t. I, diciembre de 2011 , p. 535.

21 Tesis P./J. 23/99, Semanario Fudicial de la Federación y su Gaceta, Novena Época, t. IX, abril de 1999, p. 256. 
Este libro forma parte del acervo de la Biblioteca Jurídica Virtual del Instituto de Investigaciones Jurídicas de la UNAM

Debido a lo anterior, ante la separación en México de la institución presupuestaria en dos ordenamientos distintos; la Ley de Ingresos y el PEF, establece que el primero es "el conjunto de disposiciones legales que regulan la obtención, administración y aplicación de los ingresos del Estado, otorgando competencias y estableciendo derechos y obligaciones para la administración pública y para los particulares", 22 mientras el segundo como "el decreto que contempla y autoriza las erogaciones necesarias para la realización de las actividades, obras y servicios públicos durante un periodo determinado". ${ }^{23}$

En tal sentido para la Corte, el PEF no es una ley sino un acto de aplicación de la Ley del Presupuesto, esto es la Ley de Ingresos, y es esta última la que concede competencias, derechos y obligaciones que deben ser aplicados y no el gasto público. Lo anterior es el resultado de una interpretación restrictiva del contenido de los propios ordenamientos jurídicos que rigen ambas instituciones y a la escasa doctrina que aplico, emergiendo los criterios antes referidos y desconociendo al gasto público las características inherentes a una norma de carácter general. ${ }^{24}$

Hoy en día el criterio antes referido continúa siendo aplicado, empero, a través de la controversia constitucional 109/2004, en su sexto considerando, existió el intento de reconocer al PEF el carácter de norma general, pero la votación minoritaria no permitió generar precedente jurisprudencial.

\section{Algunos efectos de la impugnación indirecta del PEF al violar derechos humanos}

Las personas al ya no impugnar de manera frontal al PEF sino al acto u omisión de autoridad que afectan sus derechos fundamentales, se han generado por los juzgadores los siguientes criterios en materia presupuestaria, tales como: ${ }^{25}$

22 Tesis P./J. 24/99, Semanario Fudicial de la Federación y su Gaceta, Novena Época, t. IX, abril de 1999, p. 251.

23 Idem.

$24 \mathrm{Al}$ respecto puede consultarse la sentencia recaída a la acción de inconstitucionalidad 4/98 emitida por el Pleno de la Suprema Corte de Justicia de la Nación el 28 de mayo de 1998, promovida por Sergio Manuel Aguilera Gómez y otros, en su carácter de diputados a la Asamblea Legislativa del Distrito Federal, en contra del Decreto del Presupuesto de Egresos del Distrito Federal para el Ejercicio Fiscal de 1998, emitido por la Asamblea Legislativa del Distrito Federal.

$25 \mathrm{Al}$ respecto puede consultarse la tesis P. XX/2002, Semanario fudicial de la Federación y su Gaceta, Novena Época, t. XV, abril de 2002, p. 12., y la tesis P./J. 5/2011, Semanario Fudicial de la Federación y su Gaceta, Novena Época, t. XXXIII, marzo de 2011, p. 10; tesis: II.1o.T.6 
Este libro forma parte del acervo de la Biblioteca Jurídica Virtual del Instituto de Investigaciones Jurídicas de la UNAM

$>$ El principio de modificabilidad presupuestaria. La cual atiende a que el PEF debe ajustarse a la realidad en cualquier momento para una adecuada distribución equitativa, incluso por orden judicial al violar derechos humanos los órganos públicos al aprobar el PEF y no asignar o reducir en forma injustificada recursos económicos para bienes y servicios que ya proporciona o debería proporcionar el Estado. Al respecto la Corte ha interpretado respecto al artículo 126 de la CPEUM que: ${ }^{26}$

...acepta que el presupuesto no debe ser estricto, inflexible, ni imposible de modificar, pues prevé la posibilidad de que pueda variarse al establecer que no podrá hacerse pago alguno que no esté comprendido en el presupuesto o determinado por ley posterior, de donde se desprende que en el propio texto de la norma constitucional referida, subyace el principio de modificación presupuestaria, al permitir que el gasto pueda programarse en dos momentos, uno anterior y otro posterior, a saber: a) $\mathrm{Al}$ aprobarse el presupuesto de egresos; o, b) En ley posterior, la que por su cronología necesariamente sucede a aquel proyecto presupuestario original en el tiempo; de manera que el precepto constitucional en mención, en lugar de constituir un valladar insuperable para la autoridad responsable, prevé la posibilidad de modificación del presupuesto original para adecuarlo a las necesidades sobrevenidas, es decir, su virtud es la de establecer un remedio para los casos fortuitos, que le permite solicitar los ajustes presupuestarios necesarios para enfrentar las obligaciones pecuniarias del Estado, gasto que necesaria e ineludiblemente debe autorizarse por tratarse del cumplimiento de un mandato de amparo cuya ejecución es impostergable.

El deber de los entes públicos de eficientar los recursos asignados independientemente de haber solicitado una mayor reasignación presupuestaria. Con independencia de la solicitud formulada por los órganos del Estado para que el órgano legislativo amplíe el presupuesto público, y cumplimentar un fallo de amparo, los órganos del Estado deben adoptar todo tipo de mecanismos para eficientar los recursos de la partida presupuestal previamente autorizada: ${ }^{27}$

L (10a.), Semanario Fudicial de la Federación y su Gaceta, Décima Época, t. II, febrero de 2013, p. 1301; y, respecto al último de los criterios, la tesis I.3o.(I Región) 19 A (10a.), Semanario Fudicial de la Federación y su Gaceta, Décima Época, t. II, diciembre de 2013, p. 1207; y la tesis I.3o.(I Región) 20 A (10a.), Semanario fudicial de la Federación y su Gaceta, Décima Época, t. II, diciembre de 2013, p. 1208.

26 Tesis P. XX/2002, Semanario Judicial de la Federación y su Gaceta, Novena Época, t. XV, abril de 2002, p. 12.

27 Tesis P./J. 5/2011, Semanario Fudicial de la Federación y su Gaceta, Novena Época, t. XXXIII, marzo de 2011, p. 10. 
Este libro forma parte del acervo de la Biblioteca Jurídica Virtual del Instituto de Investigaciones Jurídicas de la UNAM

...aunque las diversas autoridades vinculadas al cumplimiento del fallo protector pueden solicitar al órgano legislativo competente o, en el ámbito municipal al Ayuntamiento, la ampliación del presupuesto respectivo, también tienen la obligación de instrumentar los mecanismos de transferencias o adecuaciones de las partidas que integran el presupuesto previamente autorizado, tomando en cuenta, por una parte, el carácter preferente que asiste a la respectiva obligación constitucional de pago - la que debe cumplirse en el plazo fijado en la sentencia respectiva- $y$, por otra parte, que ninguna disposición legal de rango inferior a la Constitución General puede condicionar su acatamiento.

La vulneración del derecho al acceso a la justicia y administración de justicia pronta y expedita a falta de asignación presupuestaria. En la creación interpretativa por Tribunales Colegiados, respecto a disposiciones constitucionales así como de la Convención Americana de Derechos Humanos, se encuentra aquel precedente que argumenta la afectación que puede tener todo justiciable por el indebido retraso de su juicio o proceso respectivo cuando esta se debe a la indebida e insuficiente asignación de partida presupuestal en el PEF, lo que produce que no haya suficiente cobertura en la atención y administración de justicia pronta y expedita. Criterio que resulta aplicable hacia cualquier órgano que ejerce o desempeña funciones jurisdiccionales: ${ }^{28}$

...cuando en vía de amparo el quejoso reclama del Juez natural el indebido retraso en la tramitación de su demanda y de las autoridades que intervienen en la elaboración del presupuesto de egresos, como causante de la dilación, el no haber asignado al tribunal al que pertenece el Juez una partida presupuestal suficiente para atender en los términos de ley sus cargas de trabajo, y queda acreditado el retraso de mérito, sin que dichas autoridades aleguen y menos aún demuestren haber tenido una participación en el ámbito de sus atribuciones tendente a lograr la asignación de dicha partida o, en su defecto, que la insuficiente asignación fue la que los ingresos del Estado permitió sin detrimento de la asignación de recursos económicos a otras tareas públicas; queda evidenciado que tal proceder conculca el referido derecho a la impartición de una justicia pronta y expedita, por lo que debe otorgarse la protección constitucional para que en el ámbito de sus facultades y hasta que concluya el juicio natural, coadyuven a la asignación en el presupuesto de egresos de una partida razonable para atender, en los términos legales, las demandas de justicia de la población, pues limitar la concesión del amparo para que el Juez dicte el auto omitido y en lo sucesivo

28 Tesis II.1o.T.6 L (10a.), Semanario Fudicial de la Federación y su Gaceta, Décima Época, t. II, febrero de 2013, p. 1301. 
Este libro forma parte del acervo de la Biblioteca Jurídica Virtual del Instituto de Investigaciones Jurídicas de la UNAM

respete los plazos establecidos en la ley para la resolución del asunto, cuando ya quedó evidenciado la violación a tal derecho por parte de las autoridades que intervienen en la elaboración del presupuesto de egresos, tendría el pernicioso efecto de agravar la situación de los justiciables que presentaron sus demandas antes del quejoso y que no han promovido juicio de amparo, pues al cumplir el órgano jurisdiccional con la ejecutoria que concede la protección federal y observar en el procedimiento del quejoso los términos y plazos establecidos en la ley, los procedimientos de aquéllos quedarían aún más rezagados, y ninguna concesión de amparo puede tener tal efecto.

El desarrollo de un criterio interpretativo en evolución acerca del carácter de ley en sentido formal y material del PEF. Hoy el trabajo de tribunales inferiores a la SCJN han comenzado a advertir lo que ya es evidente, que el PEF es una norma jurídica en sentido formal como material, debido a que la parte respectiva de ingresos y la de gastos forman parte de un acto legislativo que no es más que una ley, así el PEF es una norma jurídica en sentido formal al ser aprobado por la Cámara de Diputados conforme al artículo 74, fracción IV Constitucional, pero también materialmente porque regula la forma de gastar el dinero del Estado, y en consecuencia crea, modifica o extingue situaciones jurídicas de la administración como de particulares - acreedores y deudores - a quienes se encuentra dirigida. ${ }^{29}$

Como puede advertirse, el ente legislativo, al aprobar el PEF, puede no asignar o reducir recursos económicos de los cuales dependen los servicios que deben proporcionar los demás órganos del Estado para satisfacer los derechos de las personas que dependen de tales bienes, y una vez asignados, en algunos casos, cuando a los órganos públicos se les ha proporcionado dinero pero no desean ejercerlo, se produce la afectación de los derechos fundamentales que debe satisfacer el propio Estado.

Debido a lo anterior, resulta necesario que sea impugnable el PEF en el caso de violar derechos fundamentales. Desafortunadamente, atendiendo a la actual jurisprudencia de la SCJN que determina en forma incorrecta la naturaleza del gasto público como acto administrativo mas no como ley, no son idóneas las actuales garantías, pues la acción de inconstitucionalidad busca eliminar del sistema jurídico una ley contraria a la CPEUM, pero al decir la Corte que el gasto no tiene el carácter de ley, resulta improcedente. Por otra parte la controversia constitucional, si bien puede ser utilizada para decla-

$29 \mathrm{Al}$ respecto puede consultarse la tesis I.3o.(I Región) 19 A (10a.), Semanario fudicial de la Federación y su Gaceta, Décima Época, t. II, diciembre de 2013, p. 1207; asimismo, la tesis I.3o.(I Región) 20 A (10a.), Gaceta del Semanario fudicial de la Federación, Décima Época, t. II, diciembre de 2013, p. 1208. 
Este libro forma parte del acervo de la Biblioteca Jurídica Virtual del Instituto de Investigaciones Jurídicas de la UNAM

rar invalido el supuesto acto administrativo, sus alcances varían entre partes o generales, dependiendo del número de votos alcanzados por los ministros.

Por último, el juicio de amparo, al utilizarse en forma indirecta contra actos de autoridad en la aprobación del presupuesto público, aun con las recientes actualizaciones está limitado respecto al alcance de la modificación del gasto público debido al efecto relativo de la sentencia de amparo, tal como lo indica el artículo 73 de la Ley de Amparo.

La casuística que ya se presenta en el país evidencia que cada vez más las personas acuden a los tribunales a efecto de impulsar políticas públicas que satisfagan sus derechos. Ello es así, pues ya se encuentran antecedentes donde se controvierten derechos como a la salud, a la educación, a un medio ambiente sano, derecho a la consulta, a la libre determinación, al agua, a la vivienda por ejemplo, muchos de ellos asesorados por grupos de litigio estratégico cuyos éxitos continúan siendo asombrosos y que contribuyen al desarrollo de la propia ciencia del derecho.

Saltan a la vista dos importantes sentencias, las cuales no derivaron en criterios sólidos de jurisprudencia, sin embargo, la justiciabilidad de los derechos inmersos permitió proteger los derechos controvertidos y en forma expresa, no aducir "escasez" de recursos económicos:

\section{A. Caso Mini Numa}

Se trata de una comunidad indígena Na Savi — mixteca- ubicada en el Municipio de Metlatónoc, estado de Guerrero, quienes al sufrir por problemas de salud, y sumado a las grandes deficiencias de la Casa y Centro de Salud existentes por falta de medicamentos y atención; por falta de personal médico, se causaba la muerte de personas, y después de esfuerzos infructuosos de solicitud a diversas autoridades de dicha cobertura, promovieron un juicio de amparo - antes de la reforma constitucional en materia de derechos humanos y de amparo - por violación al derecho a la protección de la salud contenido en el artículo 4o. constitucional. El juez al valorar las circunstancias identifica que se trata de un servicio público que debe brindarse a los habitantes a través de los establecimiento públicos de salud con base en la universalidad y gratuidad. ${ }^{30}$

Se da cuenta de la imposibilidad de crear un centro de salud de acuerdo a los requisitos del Modelo Integrador de Atención a la Salud (MIDAS),

30 Sentencia de juicio de amparo 1157/2007-II emitida por el Séptimo Juzgado de Distrito en el estado de Guerrero, de 11 de julio de 2008. 
Este libro forma parte del acervo de la Biblioteca Jurídica Virtual del Instituto de Investigaciones Jurídicas de la UNAM

pero al existir una casa de salud se le debe dotar de lo necesario para satisfacer el derecho a la salud. Por ello ordenó al gobernador y secretario de Salud de dicha entidad federativa proporcionar a la Casa de Salud elementos básicos para su funcionamiento como acondicionamiento, mobiliario y medicamentos adecuados para atender la cartera de servicios establecidos en el MIDAS. Asimismo, suministrar al Centro de Salud, un inmueble adecuado para funcionar como corresponde, con elementos y servicios para tal fin, con infraestructura, personal adecuado y medicamentos básicos, conforme al MIDAS, y sin que puedan alegar falta de presupuesto público para incumplir con tal derecho.

\section{B. Pabellón 13}

Debido a que el Instituto Nacional de Enfermedades Respiratorias (INER) atendía a pacientes con VIH/SIDA sin reunir condiciones adecuadas para los pacientes, se le autorizo una suma de dinero por el Comité Técnico del Fideicomiso del Sistema de Protección Social en Salud para remodelar y equipar el servicio clínico 4, pero atendiendo que el INER solicitó sustituir la remodelación por la construcción del pabellón 13, autorizó la cancelación del proyecto anterior - el 3 de julio del 2008 - y asignó determinada cantidad para elaborar el diseño del proyecto solicitado, sin embargo, paso el tiempo sin existir novedad alguna, es por ello que el 20 de diciembre del 2012 diversos pacientes presentaron demanda de amparo por violación a sus derechos contenidos en los artículos 1o., 4o., 14 y 16 Constitucional. ${ }^{31}$

No se tuvo éxito en primera instancia ni mucho menos con el recurso de revisión, pero al llegar a la SCJN esta redefinió la litis planteada, identificó la ausencia de proporcionar recursos económicos, la errónea valoración de los juzgadores previos, y en base a la existencia del derecho internacional justificó el control judicial de las políticas públicas, de forma que ordenó que el INER, en coordinación con el Comisionado Nacional de Protección en Salud y el Comité Técnico del Fideicomiso en Protección Social en Salud adoptaran todas la medidas necesarias y el uso del máximo de recursos para proteger el derecho humano al nivel más alto posible a la salud de los quejosos en un plazo breve, deliberadas, concretas y orientadas a satisfacer los deberes insertos en el artículo 12 del PIDESC. Aunado que con el

31 Cfr. Sentencia recaída del amparo en revisión 378/2014, Segunda Sala de la Suprema Corte de Justicia de la Nación. 
Este libro forma parte del acervo de la Biblioteca Jurídica Virtual del Instituto de Investigaciones Jurídicas de la UNAM

presupuesto que cuentan decidan entre la remodelación o construcción del pabellón, pero se indicó que las responsables no pueden aducir limitación de recursos sin acreditarlo.

Si bien diversos asuntos han llegado al ámbito judicial y pueden lograr la declaración expresa por la Corte de ser justiciables y protegidos, sin duda alguna su ejecución constituye un problema donde bien puede acontecer la dilación en el tiempo para su cumplimiento total, parcial o el no cumplimiento de la ejecutoria, el paso del tiempo suficiente para archivar el asunto como concluido y volver a reincidir en los actos u omisiones o inclusive el disfraz o disimulo que pueden efectuar las autoridades al respecto.

Es evidente cómo toda acción pública requiere de dinero, se han buscado a través del litigio estratégico adecuados planteamientos y en otros ha sido el propio juez de manera oficiosa quien le ha indicado a los entes públicos competentes administrativos no aducir "falta de presupuesto" para dejar de cumplir con sus obligaciones, lo que ha implicado que se esfuerce en desempeñar mayor eficiencia en la distribución de recursos económicos. No obstante, no existen precedentes de orden judicial o exhorto a algún congreso de alguna entidad federativa o a la Cámara de Diputados sobre la distribución o redistribución equitativa en el PEF.

Lo anterior, nos invita a reflexionar que las reformas o actualizaciones al sistema jurídico no deben ser aisladas sino integrales, ello incluye la emisión de criterios de interpretación de la SCJN. El Estado debe desplegar políticas públicas pero también asignarles recursos económicos, finalmente, la satisfacción de los derechos humanos por el Estado es uno de los objetivos que le da existencia.

\section{CONCLUSIONES}

El Estado debe efectivizar los derechos fundamentales a los cuales se ha comprometido, al menos con un núcleo mínimo esencial, por medio de diversas políticas públicas bajo la perspectiva de derechos humanos, y asignarles dinero suficiente para que sean ejecutadas.

Los deberes adquiridos por el Estado con motivo de la reforma de la CPEUM en materia de derechos humanos, implica que aquel deba cumplir con estándares constitucionales e internacionales como son: uso máximo de recursos, progresividad, medidas adecuadas, recursos efectivos, tomar en cuenta el desarrollo del país, la no discriminación, niveles minimos de satisfacción de los derechos y protección de miembros vulnerables de la sociedad en tiempos graves de recursos. 
Este libro forma parte del acervo de la Biblioteca Jurídica Virtual del Instituto de Investigaciones Jurídicas de la UNAM

Entre las instituciones jurídicas rezagadas, se encuentra el PEF, el cual, ante su inminente relación con los derechos humanos debe aclarar su verdadera naturaleza como ley a través de una reforma en la CPEUM o por medio de la mutación constitucional, facilitando que los medios de control constitucional correctivos puedan cumplir con su función en el tema, al fomentar una mejor distribución de la riqueza del país en cumplimiento de los derechos de las personas.

Los precedentes emitidos por la SCJN en el tema presupuestario se emitieron en un contexto social y político que ha dejado de responder en la actualidad; ello ha incentivado que desde tribunales inferiores a la jerarquía de la Corte se impulse la discusión y seguramente muy pronto motivaría la superación de la actual jurisprudencia que niega el carácter de ley al PEF.

La satisfacción de los derechos fundamentales deben ser progresivos y sólo en forma excepcional se les dará efecto regresivo, una vez que el Estado demuestre justificadamente que ha hecho todo lo posible a través de diversas medidas y acciones, y desafortudamente ya no existe otra opción.

\section{FUENTES DE INFORMACIÓN}

Álvarez Ledezma, Mario I., "Derechos humanos y políticas públicas", en Rossi, Andrea y ZaVALA, Luis Eduardo (coords.), Politicas públicas y derechos humanos en México, México, ITESM, 2010.

CHRISTIAN RÖHL, Hans, "El derecho administrativo como ciencia", en SANTOFIMIO GambOA, Jaime Orlando et al. (eds.), Perspectivas de una reforma. Estudios de derecho administrativo a partir de la obra de Eberhard Schmidt-Assmann, Bogotá, Universidad Externado de Colombia, 2016.

Ferrajoli, Luigi, Derechos y garantías. La ley del más débil, 7a. ed., España, Trotta, 2010.

FERrajoli, Luigi, "Jurisdicción y democracia", en CARbOnell, Miguel et al. (comps.), fueces y derecho, 2a. ed., México, Porrúa, 2008.

Holmes, Stephen y Sunstein, Cass R., El costo de los derechos. Por qué la libertad depende de los impuestos, trad. de Stella Mastrangelo, Argentina, Siglo XXI, 2011.

Mejorada Fernández SÁnchez, Cristina, "La participación ciudadana", en GARZA, Gustavo y SchteInGaRT, Martha (coords.), Los grandes problemas de México, México, El Colegio de México, 2010, t. II "Desarrollo urbano y regional". 
Este libro forma parte del acervo de la Biblioteca Jurídica Virtual del Instituto de Investigaciones Jurídicas de la UNAM

Ortega Maldonado, Juan Manuel, Lecciones de derecho fiscal, 2a. ed., México, Porrúa, 2012.

Rodríguez GaraVito, César y RodríGuez Franco, Diana, "Un giro en los estudios sobre derechos sociales: el impacto de los fallos judiciales y el caso del desplazamiento forzado en Colombia", en COURTIS, Christian y ÁVILA SANTAMARÍA, Ramiro (eds.), La protección judicial de los derechos sociales, Ecuador, Ministerio de Justicia y Derechos Humanos, 2009.

TAPIA Álvarez, Mónica, "Organizaciones de la sociedad civil y políticas públicas", en MéNDEZ, José Luis (coord.) Los grandes problemas de México, t. XIII "Políticas Públicas", México, El Colegio de México, 2010.

VÁsquez Colmenares G., Pedro, "La planeación, el presupuesto y las políticas públicas", en MÉNDEZ, José Luis (coord.) Los grandes problemas de México, México, El Colegio de México, 2010, t. XIII "Políticas Públicas".

Consejo Nacional de Evaluación de la Política de Desarrollo SOCIAL, "Medición de la pobreza", disponible en: http://wrere.coneval.org. $m x / M e d i c i o n / M P / P a g i n a s / P o b r e z a \_2014$.aspx, consultado el 1o. de febrero de 2017.

Instituto Nacional de Estadística y Geografía, "México en cifras", disponible en: http://wrere.beta.inegi.org.mx/app/areasgeograficas/, consultado el 1o. de febrero de 2017.

Blyberg, Ann, "El caso de la asignación incorrecta: derechos económicos y sociales y el trabajo presupuestario", Sur. Revista Internacional de Derechos Humanos, Brasil, vol. 6, núm.11, diciembre de 2009, semestral.

Huerta Lara, Ma. del Rosario, "El bloque de constitucionalidad y el nuevo juicio de amparo", Letras jurídicas, México, núm. 26, julio-diciembre de 2012.

CORTI, Horacio, "Las coordenadas claves de la discusión", mesa II, Seminario Internacional Derechos Humanos: Presupuesto Públicos y Control Judicial, México, UNAM, Instituto de Investigaciones Jurídicas, 4 de abril de 2011, disponible en: https://wrerc.juridicas.unam.mx/videoteca/ evento/seminario-internacional-derechos-humanos-presupuestos-publicos-y-control-ju dicial/2011-04-04/mesa-2-las-coordenadas-claves-de-la-discusion. 
Este libro forma parte del acervo de la Biblioteca Jurídica Virtual del Instituto de Investigaciones Jurídicas de la UNAM

\title{
TRATAMIENTO JURISPRUDENGIAL DE LOS PRESUPUESTOS PÚBLICOS Y DERECHOS HUMANOS EN COLOMBIA
}

\author{
Lizeth Juliana GARCíA ATRA*
}

\begin{abstract}
SumARIO: I. Introducción. II. Caso 1. Sentencia unificada 225 de 1998. Exp. T-140800. III. Caso 2. Sentencia de tutela 025 de 2004. Exp. T-653010. IV. Caso 3. Sentencia T-406/92. V. Caso 4. Sentencia C-753/13, demanda de inconstitucionalidad contra el artículo 19 (parcial) de la Ley 1448 de 2011. VI. Conclusiones.
\end{abstract}

\section{INTRODUGCIÓN}

Evidentemente, con el advenimiento del fenómeno globalizador, los Estados nación en Latinoamérica han introducido en sus textos constitucionales artículos que permitan la materialización de los derechos humanos. A manera de ilustración se pueden tomar como referencia próxima países como Colombia y México; en efecto, el primero de ellos lo hizo en su Constitución Política de 1991, concretamente, en el artículo 93 que da tratamiento al bloque de constitucionalidad y en el que se hace expresa alusión a lo que se citará:

Artículo 93. Los tratados y convenios internacionales ratificados por el Congreso, que reconocen los derechos humanos y que prohíben su limitación en los estados de excepción, prevalecen en el orden interno. Los derechos y deberes consagrados en esta Carta, se interpretarán de conformidad con los tratados internacionales sobre derechos humanos ratificados por Colombia. ${ }^{1}$

* Licenciada en derecho por la Universidad Colegio Mayor de Cundinamarca (Bogotá, Colombia), maestra en derecho por la Universidad Autónoma del Estado de Morelos, México.

1 Constitución Política de Colombia, Bogotá, Consejo Superior de la Judicatura, 2015, p. 27. 
Este libro forma parte del acervo de la Biblioteca Jurídica Virtual del Instituto de Investigaciones Jurídicas de la UNAM

Del mismo modo en México, el 6 y 10 de junio de 2011, se procedió con la publicación de dos reformas a la Constitución Política de los Estados Unidos Mexicanos que impactaban directamente en la administración de justicia federal; una de ellas tuvo relación justamente con el reconocimiento de la progresividad de los derechos humanos mediante la expresión clara del principio pro persona como rector de la interpretación y aplicación de las normas jurídicas, en aquellas que favorecieran y brindaran mayor protección a las personas. ${ }^{2}$

No obstante, este reconocimiento conllevó a un garantismo constitucional que generó la necesidad de crear leyes que, desde el punto de vista presupuestal, permitieran la materialización de esos derechos humanos. Sin embargo, a pesar de que quien tenía a su cargo esta imperiosa labor era justamente el legislador, quien terminó ejecutándola fue el Poder jurisdiccional, para el caso colombiano, a través de la Corte Constitucional.

En este orden de ideas valdría la pena examinar algunos de los precedentes jurisprudenciales que sustentan la afirmación enunciada y que se han convertido en sentencias hito, en la medida que, a través de éstas se ha logrado el reconocimiento de múltiples derechos y garantías de orden constitucional.

Antes de proceder con este análisis, desde el punto de vista conceptual, resulta pertinente mencionar que en Colombia los presupuestos públicos han sido concebidos como una herramienta fundamental para la ejecución de la política económica del Estado, a través de la cual ejerce su función de financiador o proveedor directo de bienes y servicios y se atiende el funcionamiento de sus entidades y el financiamiento adquirido para el desarrollo de sus actividades. ${ }^{3}$

Adicionalmente, como lo ha llegado a referir en su oportunidad la Corte Constitucional colombiana, el presupuesto general de la nación ha estado supeditado por directrices y principios no sólo de la Constitución, sino en las leyes y normas de su ordenamiento jurídico.

Recuérdese además que la Corte Constitucional, en sentencia C-935 de 2004, hizo especial hincapié en que cuando se elabora el presupuesto, el gobierno debe tener en cuenta que éste debe corresponder al Plan Nacional de Desarrollo; asimismo, el proyecto de Ley de Apropiaciones debe contemplar los gastos que el Estado posiblemente realice durante la vigencia

2 Suprema Corte de Justicia de la Nación, Reformas Constitucionales en materia de Amparo y Derechos Humanos publicadas el junio de 2011, disponibles en: http://wrew 2.scjn. gob. $m x /$ red/constitucion/inicio.html.

3 Ministerio de Hacienda y Crédito Público, Aspectos generales del proceso presupuestal colombiano, 2a. ed., Bogotá, 2011. 
Este libro forma parte del acervo de la Biblioteca Jurídica Virtual del Instituto de Investigaciones Jurídicas de la UNAM

fiscal correspondiente y, en la Ley de Apropiaciones, debe incluirse el gasto público social que no sólo tiene prioridad sobre cualquier otra asignación, sino que contemplará a las personas con necesidades básicas no satisfechas, la población y eficiencia fiscal y administrativa. Hechas estas precisiones se procederá con el análisis enunciado en líneas anteriores.

\author{
II. CASO 1 \\ SENTENCIA UNIFICADA 225 DE 1998. EXP. T-140800 \\ Sandra Clemencia Pérez Calderón y otros contra Ministerio de Salud. \\ Magistrado Ponente: Dr. Eduardo Cifuentes Muñoz
}

El primer precedente jurisprudencial por considerar es la sentencia unificada 225 de 1998, mediante la cual 418 padres de familia, a través de la Fundación para la Defensa del Interés Público, interpusieron una acción de tutela contra el Ministerio de Salud y la Secretaría Distrital de Salud de Bogotá al considerar que estos organismos públicos vulneraron los derechos fundamentales a la vida, salud y seguridad social de sus hijos cuando no les fue suministrada de manera gratuita, la vacuna contra la meningitis.

El apoderado judicial de los actores aclaró que eran trabajadores del sector informal o madres cabeza de hogar de escasos recursos económicos, razón por la cual se les dificultaba costear la atención en salud de sus hijos menores de edad y estaban desvinculados a instituciones prestadoras de servicio público de seguridad social.

Del mismo modo, se enfatizó en que la jurisprudencia de la Corte Constitucional había señalado que los derechos a la salud y a la seguridad social de los niños son derechos fundamentales que prevalecen sobre los de los demás y que pueden ser protegidos en forma directa a través de la acción de tutela.

Posteriormente, mediante sentencia del 17 de julio de 1997, el Juzgado 12 de Familia de la ciudad de Bogotá tuteló los derechos a la vida, salud y seguridad social de los hijos de los demandantes, recordando que el artículo 44 de la Constitución Política colombiana consagraba que los derechos de los niños, eran fundamentales y que dentro de esa gama se encontraba justamente el de la salud.

A continuación, le correspondió a la Corte Constitucional, atendiendo a la naturaleza e importancia de este fallo, proceder con la revisión del mismo, a fin de verificar si se ajustaba o no a la Constitución.

En este sentido recordó la Corte el carácter fundamental de los derechos de los niños, especialmente atendiendo a que Colombia es un Estado 
Este libro forma parte del acervo de la Biblioteca Jurídica Virtual del Instituto de Investigaciones Jurídicas de la UNAM

social de derecho, entendido como aquel que acepta e incorpora al orden jurídico, a partir de su propia Constitución, derechos sociales fundamentales junto a los clásicos derechos políticos y civiles,${ }^{4}$ y que dentro de este resultaba indispensable que la comunidad política brindara un trato preferencial a quienes estén en situación de debilidad manifiesta e impedidos para participaren la adopción de las políticas públicas que se les pudiera aplicar.

Destacó además la enunciada Corte que conforme a la cláusula del citado Estado la individualización de los derechos sociales, económicos y culturales no puede estar al margen de la ley y posibilidades de orden financiero del Estado, de forma que el legislador está en la facultad de proceder con la ejecutar el mandato social de la Constitución y, para el efecto, está obligado a crear instituciones y destinar de forma prioritaria los recursos del erario que se requieran para su materialización.

Ahora bien, aunque en sentencia 111 del año 1997, ${ }^{5}$ la Corte Constitucional llegó a referir que no estaba facultada, inicialmente, para intervenir en el proceso de asignación de derechos constitucionales de índole presupuestal en la medida en que estaría lesionando el principio de la democracia y derechos como el de la igualdad, siendo entonces que los derechos no son de aplicación inmediata, también resaltó que, en casos concretos, corresponde al juez constitucional la potestad de conceder un derecho social o económico cuando se emplee, para el efecto, la interposición de la acción de tutela.

Sería pertinente precisar, antes de continuar con el estudio que aquí se pretende, en qué consiste conceptualmente la "acción de tutela". En efecto, ésta ha sido entendida como un mecanismo procesal constitucional que puede emplear cualquier persona cuando sus derechos, de carácter fundamental, hayan sido quebrantados o exista amenaza de violación o vulneración por parte de una autoridad pública; no obstante, en el marco constitucional, ha sido entendida como una garantía que toda persona tendrá para reclamar ante los jueces, en cualquier momento y lugar, mediante un procedimiento preferente y sumario, por sí misma o por quien actúe a su nombre, la protección inmediata de sus derechos constitucionales fundamentales, cuando quiera que estos resulten vulnerados o amenazados por la acción o la omisión de cualquier autoridad pública. ${ }^{6}$

4 Villar Borda, Luis, "Estado de derecho y Estado social de derecho", Revista Derecho del Estado, Bogotá, núm. 20, diciembre de 2007, p. 86.

5 República de Colombia, Corte Constitucional, "Sentencia de Unificación 111 de 1997", disponible en: http://wrere.corteconstitucional.gov.co/relatoria/1997/SU111-97.htm.

6 Constitución Política de Colombia, disponible en: http://wrere.corteconstitucional.gov.co/ inicio/Constitucion\%20politica\%20de\%20Colombia\%20-\%202015.pdf. 
Este libro forma parte del acervo de la Biblioteca Jurídica Virtual del Instituto de Investigaciones Jurídicas de la UNAM

Debe tenerse presente, además, el carácter subsidiario de esta acción, ya que el ciudadano cuenta normalmente con otros medios judiciales de carácter ordinario que tienen preferencia sobre la tutela y que hacen posible su interposición en un momento posterior. Sin embargo, también es procedente interponer la acción de tutela cuando tales mecanismos ordinarios no permiten llevar a cabo la protección de derechos, o aun protegiéndolos, recurrir a ellos podría significar la materialización de un perjuicio irremediable.

Puede verse entonces que la acción de tutela se ha convertido en el mecanismo jurídico por excelencia al que acuden los particulares para hacer efectivos sus derechos constitucionales fundamentales, así se cuenten, para el efecto, con otros instrumentos del mismo orden. Ello se explica porque, como es común, los países latinoamericanos se han visto seriamente afectados por una serie de factores que generan en la ciudadanía una sensación de inconformidad e incredibilidad respecto a la forma en la que se administra justicia, por ser tardía y débil.

Debe recordarse entonces, que en la práctica jurídica colombiana, el derecho a la salud (abordado por la sentencia que se estudia) ha sido vinculado directamente con el derecho fundamental a la vida, de ahí que se explique, como acertadamente lo refiere la Defensoría del Pueblo el aumento ostensible de la interposición de acciones de tutela. Efectivamente, afirma esta institución gubernativa que mientras en el 2010 presentaron 94,502 acciones de tutelas en salud, y en 2014 el número de acciones para reclamar por este derecho fundamental aumentó a 118,281; sumado a lo anterior, el $70 \%$ de las solicitudes de los ciudadanos en materia de violaciones a su derecho fundamental a la salud está relacionado con solicitudes ya incluidas en el Plan Obligatorio de Salud en Colombia. ${ }^{7}$

Sin embargo, atendiendo no sólo al aumento expuesto sino al carácter subsidiario propio de la acción de tutela, valdría la pena formular la siguiente pregunta: ¿en qué casos debería intervenir la Corte Constitucional para que se hicieran efectivos los derechos constitucionales de los ciudadanos? A este cuestionamiento da respuesta el referido órgano constitucional al considerar que la acción de tutela tiene un alcance procesal limitado que opera en la práctica cuando un derecho (sea este fundamental, económico social o cultural) es conexo a las pretensiones que se amparan por vía de la tutela; a manera de ilustración, cuando se atenta contra la dignidad huma-

7 Defensoría del Pueblo, "Sigue creciendo el número de tutelas en salud", disponible en: http://wrerr.defensoria.gov.co/es/nube/noticias/3414/Sigue-creciendo-el-n\%C3\%BAmero-detutelas-en-salud-Tutelas-salud-D\%C3\%ADa-Mundial-de-la-salud-justicia-Plan-Obligatorio-de-SaludFallos-de-tutela-Derechos-Humanos-EPS.htm. 
Este libro forma parte del acervo de la Biblioteca Jurídica Virtual del Instituto de Investigaciones Jurídicas de la UNAM

na de las personas que pertenecen a grupos en situación de vulnerabilidad dentro de la población y el Estado ha omitido prestar el apoyo correspondiente.

Por otro lado, como lo reconoció la misma Corte Constitucional en este precedente, los derechos de orden prestacional se constituyen, per se, como fundamentales de aplicación inmediata y ostentan un doble contenido, esto es, que están compuestos de un núcleo esencial mínimo que no es negociable y conforme al cual se confieren derechos de carácter subjetivo que son perfectamente exigibles mediante la acción de tutela.

Así, no debe perderse de vista que el derecho a la salud, que es en un principio derecho prestacional (en este caso de los niños), se debe considerar realmente como un derecho de carácter mínimo, de forma que correspondería al Estado y los órganos que de él dependen la definición de sistemas de prevención y atención para la adecuada materialización del mismo, con independencia de que exista, para el efecto, una mediación de orden legislativo o administrativo. Aunado a lo anterior, debe considerarse que la satisfacción de las necesidades de los niños no puede quedar sometida a la mayoría política.

Aclárese además que el núcleo esencial de los derechos fundamentales de los niños puede ser, sólo en casos especiales (como el que aquí se aborda), aplicado de forma directa por los jueces, aunque, en estricto sentido, la definición de su alcance debería estar a cargo del legislador de turno.

De la misma manera, en virtud del principio de subsidiariedad, corresponde al Estado, inicialmente a través del legislador, y posteriormente mediante la administración y órganos de control, hacer efectivas las garantías de los niños previstas en el texto constitucional, en especial, si el núcleo familiar de estos no cuenta con la capacidad económica para solventar las carencias de los niños.

Sin embargo, debe considerarse que la protección de estos derechos sólo será posible en el supuesto de que se esté desprotegiendo otros de similar categoría. Se concluye entonces que le corresponderá a la Corte Constitucional la aplicación directa, ante la ausencia una orden de carácter legislativo, del núcleo esencial citado.

En el caso estudiado por la Corte se evidenció además que la implementación de programas de vacunación para la meningitis, y concretamente, para la protección de los derechos de los niños en virtud de los cuales se había implementado el programa de vacunación, no excedía las capacidades de orden técnico y financiero del Estado, a través de sus entidades próximas, esto es, el Ministerio de Salud y concretamente, el sistema nacional de salud en Colombia. 
Este libro forma parte del acervo de la Biblioteca Jurídica Virtual del Instituto de Investigaciones Jurídicas de la UNAM

En igual sentido estimó la Corte que la carencia de una política estatal encaminada a impedir que los niños en situación de vulnerabilidad contraigan las bacterias causantes de meningitis, se configura como una omisión grave que afectaba ostensiblemente el núcleo esencial de su derecho fundamental a la salud. Sin embargo, aunque sea esta una prioridad de orden constitucional que no puede ser desconocida por los órganos gubernativos, resulta indispensable que el gobierno esté en la capacidad de obtener fondos adicionales (o preverlos presupuestalmente hablando) sin que sea necesario el simple desplazamiento de recursos de un programa concreto mediante el cual se pretende la satisfacción básica de una necesidad, a otra de naturaleza similar.

\section{CASO 2}

Sentencia DE TUTELA 025 DE 2004. ExP. T-653010

Abel Antonio Faramillo, Adela Polanía Montaño, Agripina María Nuñez contra la Red de Solidaridad Social, el Departamento Administrativo de la Presidencia de la República, el Ministerio de Hacienda y Crédito Público, el Ministerio de Protección Social, el Ministerio de Agricultura, el Ministerio de Educación, el INURBE, el INCORA, el SENA y otros

Ahora bien, se procederá con el estudio de la sentencia de tutela T-025/04 que abordó uno de los temas más álgidos del país y respecto al cual también se ha procurado la protección por vía de tutela, esto es, el desplazamiento forzado.

Resulta, sin embargo, necesario anticipar que la sentencia aquí reseñada constituye un hito jurisprudencial no sólo por el tratamiento que dio en su oportunidad a los temas de desplazamiento forzado y destinación de los presupuestos públicos en el contexto de la materialización de los derechos humanos, sino por la alusión hecha al estado de cosas inconstitucional. Aunque no se ahondará sobre este particular, es válido precisar conceptualmente el término en mención, en especial, en atención al impacto que tiene esta en el reconocimiento de derechos de carácter fundamental, como se verá en su momento.

Para Quintero y otras ${ }^{8}$ esta figura puede ser definida como un mecanismo o técnica jurídica creada por la Corte Constitucional, mediante la cual declara que ciertos hechos resultan abiertamente contrarios a la Constitución, por

8 Quintero Lyons, Josefina et al., "La figura del Estado de cosas inconstitucional como mecanismo de protección de los derechos fundamentales de la población vulnerable en Colombia”, Revista furídica Mario Alario D’Filippo, Cartagena de Indias, vol. 3, 2011 , pp. 71 y 72. 
Este libro forma parte del acervo de la Biblioteca Jurídica Virtual del Instituto de Investigaciones Jurídicas de la UNAM

vulnerar de manera masiva derechos y principios consagrados en la misma; en consecuencia insta a las autoridades competentes, para que en el marco de sus funciones y dentro de un término razonable, adopten las medidas necesarias para corregir o superar tal estado de cosas.

Sin embargo, debe destacarse el impacto que ha tenido esta figura, toda vez que como lo esgrimen los autores anteriormente citados, no deja de ser controversial, en la medida en que dista de los esquemas tradicionales de los efectos entre las partes característicos de los fallos de tutela, puesto que a través de la citada declaración el juez constitucional se compromete ostensiblemente con la sociedad y, de manera especial, con los sujetos más vulnerables dentro de ella, al pretender la búsqueda de soluciones a fenómenos de índole estructural que tengan desarrollo en el país, tomándose decisiones ultra y extra petita, que permiten la modificación de una realidad claramente contraria a los principios propios del Estado social de derecho.

Hecha esta salvedad, procede entonces el estudio de la sentencia referida. De manera sucinta debe aludirse a que en este precedente se analizaron 108 expedientes correspondientes a acciones de tutela interpuestas por 1150 núcleos de personas integrantes de la población desplazada, toda vez que tenían relación con un tratamiento inadecuado, por parte de las distintas autoridades del orden nacional, a la población desplazada. Se consideró, en su oportunidad, por parte de los actores, que no habían recibido ningún tipo de ayuda humanitaria por parte de las entidades que estaban encargadas de atenderlos; inclusive, se enfatizó en que no había sido posible recibir orientación para el acceso a programas de atención al desplazado, concretamente, aquellos que estaban relacionados de forma directa con la vivienda, proyectos productivos, atención en salud y en educación; asimismo, los desplazados fueron sometidos a una especie de peregrinaje institucional sin que se les diera una respuesta eficaz.

Adicionalmente, las respuestas dadas por las autoridades gubernamentales estuvieron enmarcadas en la falta de competencia para conceder la ayuda peticionada, la escasa disponibilidad presupuestal que permitiera atender sus solicitudes, el hecho mismo de no encontrarse inscritos en el Registro Único de Población Desplazada, o que la única forma de acceder efectivamente a la ayuda era a través de la presentación de un proyecto productivo. Destáquese además que dentro del presente proceso, la mayoría de las tutelas fueron denegadas en la primera instancia.

Ante la falta de respaldo de los distintos entes gubernativos, la Corte procedió con el análisis de las tutelas correspondientes y consideró, en síntesis, que entre los problemas que debían tratarse se encontraban los siguientes: a) la grave vulnerabilidad que afecta a la población desplazada; $b$ ) los proble- 
Este libro forma parte del acervo de la Biblioteca Jurídica Virtual del Instituto de Investigaciones Jurídicas de la UNAM

mas que enfrentan gracias a la manera en que se están atendiendo sus solicitudes; c) el tiempo transcurrido sin obtener las ayudas correspondientes y d) el ostensible número de tutelas presentadas por esta población.

Lo anterior, llevó además a la Corte a cuestionarse sobre la procedibilidad de la tutela para el examen de acciones y omisiones de autoridades de carácter público (respecto a la atención integral de población desplazada); la vulneración a los derechos al mínimo vital y una respuesta pronta a las peticiones presentadas por la citada población, cuando el acceso estaba ceñido a la existencia de recursos no apropiados por el Estado; si existía una vulneración a diversos derechos de rango constitucional cuando se omitía o negaba una respuesta de fondo a la ayuda solicitada; la precaria apropiación de recursos destinados para atender esas solicitudes; el incumplimiento de requisitos legales para el acceso a esta ayuda; la falta de competencia de la entidad que presenta la solicitud y si las asociaciones que presentaron la acción de tutela se encontraban legitimadas para interponerlas, aun cuando no contaran con un poder específico para este fin.

Examinados los referidos supuestos fácticos y jurídicos, la Corte evidenció la violación del derecho a la vida digna, igualdad, integridad personal, petición, trabajo, salud, seguridad social, educación, mínimo vital y protección especial debida a las personas de la tercera edad, a la mujer cabeza de familia y a los niños ante la falta de atención de las autoridades públicas y afirmó la existencia de un estado inconstitucional de las cosas.

Sumado a lo anterior, aunque desde las diversas ramas del poder público se procuró atender a esta parte de la población que se refirió para el caso, se llegó a la conclusión de que las políticas implementadas no bastaban para la satisfacción de sus derechos, en especial, porque no es suficiente contar con herramientas legales y jurídicas para desagraviarla, si en la práctica se hacen ostensibles las omisiones y no se adoptaban oportunamente los correctivos requeridos, no sólo por uno, sino por todos los organismos encargados de la salvaguarda de sus derechos.

Es por lo anterior que desde la Corte Constitucional se ordenó al Consejo Nacional para la Atención Integral de la Población Desplazada por la violencia que existiera coherencia entre las obligaciones fijadas por las autoridades competentes para atender a la población desplazada y el monto de recursos que se destinaba para proteger sus derechos; esto implicaba además la protección íntegra del núcleo esencial de sus derechos fundamentales constitucionales y satisfacción del mínimo prestacional de los diversos derechos que a ellos les son inherentes.

Tratándose de la competencia de las asociaciones de desplazados para la interposición de la acción de tutela, hizo hincapié la Corte en que es posi- 
Este libro forma parte del acervo de la Biblioteca Jurídica Virtual del Instituto de Investigaciones Jurídicas de la UNAM

ble hacerlo atendiendo a lo consagrado sobre el particular en el artículo 10 del Decreto 2591 de 1991 que da tratamiento a los requisitos genéricos para interponer una tutela, específicamente, al mencionar que se pueden agenciar derechos ajenos cuando el titular de los mismos no esté en condiciones de promover su propia defensa ${ }^{9} \mathrm{Y}$ esta no es la excepción, en especial, si se tiene en cuenta la evidente condición vulnerable de los desplazados. A lo anteriormente reseñado, debe sumarse que las personas desplazadas por la violencia están expuestas a una debilidad manifiesta frente a la cual deben recibir un tratamiento especial por parte del Estado. ${ }^{10}$

En este orden de ideas, consideró la Corte privilegiar el hecho de que dentro de la agenda política del Estado se tuviera en cuenta el desplazamiento interno y se priorizara. ${ }^{11}$ Asimismo, estimó necesario que el legislador de turno tuviera en cuenta que, sin perjuicio del derecho a la igualdad previsto en la Constitución Política de Colombia, las víctimas de desplazamiento merecen en definitiva, un tratamiento especializado. ${ }^{12}$

Igualmente, se hizo hincapié en que la situación de las personas desplazadas y su familia debe ser un asunto primordial para las diversas autoridades, ${ }^{13}$ especialmente, cuando en la realidad jurídica del país, a través de las políticas públicas no había sido posible disminuir el considerable deterioro de las condiciones de vulnerabilidad de los desplazados. De hecho, es inútil si se cuenta con sendas leyes, decretos, resoluciones y demás disposiciones normativas en las que se plasma una respuesta institucional al fenómeno, sin que en la práctica opere.

En efecto, la Corte aseveró que en todos los niveles de la política pública de atención a la población desplazada se evidenciaban problemas graves de orden institucional; inclusive, no había sido objeto de regulación la participación de los desplazados en la creación y ejecución de las políticas en general, de la materia, tampoco se contaba con información completa y oportuna respecto de sus derechos ni acceso a educación para los niños desplazados, y, en los programas de subsidio de vivienda no se contaba con información sobre las zonas en las que se podía proceder con la construcción de ésta.

9 República de Colombia, Corte Constitucional, sentencia SU-1150 de 2000, M.P. Eduardo Cifuentes Muñoz.

10 Idem.

11 República de Colombia, Corte Constitucional, sentencia T-215 de 2002, M.P. Jaime Córdoba Triviño.

12 República de Colombia, Corte Constitucional, sentencia T-602 de 2003, M.P. Jaime Araujo Rentería.

13 República de Colombia, Corte Constitucional, sentencia T-721 de 2003, M.P. Álvaro Tafur Galvis. 
Este libro forma parte del acervo de la Biblioteca Jurídica Virtual del Instituto de Investigaciones Jurídicas de la UNAM

A esta vaguedad normativa se sumaba la escases de recursos denunciada constantemente en los documentos aportados al proceso por los agentes oficiosos, toda vez que se logró determinar que el gobierno central había destinado recursos financieros inferiores a las necesidades de la política y muchas de las entidades territoriales no dirigían recursos propios para atender los distintos programas, especialmente, el Consejo Nacional para la Atención Integral a la Población Desplazada por la Violencia, quien estaba en la obligación de garantizar la asignación presupuestal de los programas que las entidades que tenían bajo su cargo el funcionamiento del Sistema Nacional de atención integral a la población desplazada por la violencia.

Es por lo anterior que se consideró necesario destinar el presupuesto para que los derechos fundamentales de los desplazados tuvieran una realización plena, de conformidad con el artículo 350 de la Carta que, por su parte, consagra que el gasto público social, tiene prioridad sobre cualquier otra asignación. Se aclara, en todo caso, que no es que con la acción de tutela se ordene un gasto no presupuestado o se modifique la programación presupuestal, sino que se estaba atendiendo irrestrictamente al principio de colaboración armónica, permitiéndose la protección de los derechos de todos los colombianos en el marco del Estado social de derecho y su clara dimensión prestacional.

Además, como ya se anticipó en un acápite de este escrito, al verificarse una vulneración repetida de derechos fundamentales que impactaban sobre varias personas y que requería la intervención de distintas entidades para atender problemas de orden estructural, se evidenció un estado de cosas inconstitucional ${ }^{14}$ que se confirmó con las varias acciones de tutela presentadas por esta población.

Del mismo modo se logró la identificación de problemas de coordinación, carente apropiación presupuestal, obstáculos de orden administrativo, trámites innecesarios y omisiones en la corrección de estos; de ahí que se requería del diseño y planificación presupuestal, ya que frente a prestaciones de carácter programático, estas no pueden ser exigidas de forma instantánea. ${ }^{15}$

No obstante ello, debe tenerse en cuenta que dado el alcance mismo del problema de desplazamiento en Colombia, el diseño e implementación

14 Ver entre otras, las sentencias T-068 de 1998, MP: Alejandro Martínez Caballero; T-153 de 1998, MP: Eduardo Cifuentes Muñoz; SU-250 de 1998, MP: Alejandro Martínez Caballero; T-590 de 1998, MP: Alejandro Martínez Caballero; T-606 de 1998, MP: José Gregorio Hernández Galindo; SU-090 de 2000, MP: Eduardo Cifuentes Muñoz; T-847 de 2000, MP: Carlos Gaviria Díaz; T-1695 de 2000, MP: Marta Victoria Sáchica Méndez.

15 República de Colombia, Corte Constitucional, sentencia T-595 de 2002, M.P. Manuel José Cepeda Espinosa. 
Este libro forma parte del acervo de la Biblioteca Jurídica Virtual del Instituto de Investigaciones Jurídicas de la UNAM

de políticas públicas de protección debía atender siempre a un ejercicio de ponderación, toda vez que será imposible la satisfacción, en un nivel máximo, de todos los derechos constitucionales de la población desplazada; sin embargo, lo que sí resulta claro es que deben garantizarse, al menos, los derechos a la vida, dignidad, integridad física, familia, mínimo vital entre otros.

Finalmente, la Corte ordenó que los diversos organismos del orden gubernamental aunaran esfuerzos para procurar la atención oportuna y adecuada de la población desplazada.

\section{CASO 3 \\ SENTENCIA No. T-406/92 \\ Peticionario: Fosé Manuel Rodríguez R. Magistrado Ponente: Ciro Angarita Barón}

Ahora, en este caso particular la Corte procedió a estudiar una acción de tutela que fue interpuesta por un ciudadano contra las empresas públicas de Cartagena que iniciaron, en 1991, la construcción del servicio de alcantarillado; no obstante ello, transcurrido un año y sin que se concluyera su construcción esta fue puesta en funcionamiento, hecho que produjo el desbordamiento de aguas negras por los registros, ocasionando olores nauseabundos y contaminantes de la atmósfera. El accionante manifestó haberse visto afectado porque su vivienda se encontraba frente a las obras inconclusas, pese a los sendos requerimientos por él efectuados para su terminación. Razón por la cual se solicita que a través de la jurisdicción se ordene a la entidad demandada dar continuidad de la obra hasta su terminación.

Inicialmente la Corte, previo a la resolución del problema jurídico, aclaró que la aceptación de la acción de tutela sólo era posible en el supuesto de violación de derechos humanos y fundamentales. Sin embargo, resulta igualmente indispensable recordar que el juez debe proceder con la toma de decisiones que consulten no sólo la gravedad de esta violación a la luz de los textos de orden constitucional, sino a las posibilidades de orden económico de solución de problemas que atiendan, primigeniamente, a las condiciones de escasez de recursos y, en segundo lugar, a los propósitos de igualdad y justicia social. Recuerda además en este sentido, el tribunal citado, que la aplicación de derechos de orden económico y social (entendidos estos como derechos humanos de tercera generación) plantean problemas no sólo de provisión de recursos, sino de asignación de los mismos, razón por la que resulta indispensable recordar que, como lo señala el artículo 366 de la Constitución Política colombiana, los planes y presupuestos de la 
Este libro forma parte del acervo de la Biblioteca Jurídica Virtual del Instituto de Investigaciones Jurídicas de la UNAM

nación y de las entidades territoriales referente al gasto social tendrá prioridad sobre cualquier otra asignación. Sin embargo, es posible que ella no sea lo suficientemente iluminadora para resolver el caso sin llegar a resultados inaceptables o imposibles de llevar a cabo. En consecuencia, es necesario que el juez haga uso de la lógica de lo razonable.

Adicionalmente, en el artículo en cita, se hace hincapié en que el bienestar general y el mejoramiento de la calidad de la vida de la población son finalidades sociales del Estado colombiano, y que, además, es objetivo fundamental de su actividad la solución de las necesidades insatisfechas de salud, educación, de saneamiento ambiental y de agua potable. Lo anterior hace necesario que se proceda con el diseño de mecanismos, por parte de las ramas legislativa y ejecutiva del poder público, de planes y presupuestos de la Nación y de las entidades territoriales, sin olvidar que el gasto público social tiene prioridad sobre cualquier otra asignación.

\section{CASO 4 \\ SENTENCIA C-753/13, DEMANDA DE INGONSTITUCIONALIDAD GONTRA EL ARTíCULO 19 (PARCIAL) DE LA LEY 1448 DE 2011}

Actor: Brayan Darío Tovar Badel, Magistrado sustanciador: Mauricio González Cuervo

Por otro lado, resulta relevante traer a colación la sentencia de constitucionalidad de 2013 en la que la Corte Constitucional, frente a la demanda de inconstitucionalidad de la Ley 1448 de 2011 "Por la cual se dictan medidas de atención, asistencia y reparación integral a las víctimas del conflicto armado interno y se dictan otras disposiciones" refirió que, tratándose de la reparación integral de las víctimas (y que hace posible el restablecimiento y garantía de derechos humanos que fueron violentados como consecuencia del conflicto armado), y al otorgarse una indemnización administrativa por parte del Estado éste, además de atender a la gravedad de los hechos y su condición de vulnerabilidad, debía considerar al universo de beneficiarios, así como el monto total de reparación, para la garantía del presupuesto y su implementación, sostenibilidad y viabilidad.

En efecto, señala la Corte que en un contexto de escasos recursos y violaciones masivas de derechos, en los que existen además otras poblaciones vulnerables que necesitan atención, es fundamental que las autoridades se responsabilicen fiscalmente y que sin desconocer los derechos humanos que le asisten a las víctimas, procedan con el establecimiento de estrategias de reparación con montos justos y adecuados, en plazos razonables para per- 
Este libro forma parte del acervo de la Biblioteca Jurídica Virtual del Instituto de Investigaciones Jurídicas de la UNAM

mitir la compensación de todas las víctimas. En estas condiciones, a manera de epílogo, estima la Corte que el presupuesto inicial, así como las diferentes vigencias fiscales, hasta la conclusión de la justicia transicional, debe contemplar las condiciones que conlleven a que este componente de justicia sea útil al propósito de la reparación integral, generando además oportunidades de justicia material para la población de victimas afectada.

\section{CONCLUSIONES}

a) La nueva tendencia que viene presentándose en los países latinoamericanos consiste en el reconocimiento e inclusión de los derechos humanos dentro de sus textos constitucionales, cada vez más explícitamente, acoplando los instrumentos políticos y jurídicos internos de cada legislación, con el firme propósito de que estos puedan ser realizables.

b) Como parte de dichos instrumentos, dentro de algunos ordenamientos internos, se ha estado legislando en relación a una serie de medidas presupuestales, cuya principal particularidad es el centro desde el cual se producen: el Poder Judicial. Es el caso de Colombia donde la Corte Constitucional, a través de su jurisprudencia, posibilita condiciones que son complementarias con las normas constitucionales y legales que regulan los presupuestos públicos, para que estos sean destinados al mejoramiento de las condiciones que permitan hacer materialmente realizables tales derechos y garantías.

c) La implementación de estas medidas, principalmente aquellas que tienen que ver con quienes son sujetos destinatarios de especial protección al encontrarse en situaciones de vulnerabilidad o de debilidad manifiesta (v. gr: los niños, los desplazados por la violencia, personas de la tercera edad, mujeres cabeza de hogar, etcétera), exige por parte del Estado asegurar los recursos necesarios para llevar a cabo la atención prioritaria de estas personas.

d) Aunque en un primer momento no correspondería a la Corte Constitucional asumir la competencia para intervenir dentro las facultades presupuestales del Estado, sí puede asumirla (y de hecho la asume) cuando se ha interpuesto una acción de tutela, así, esta herramienta se ha convertido en el principal instrumento para el reconocimiento de derechos sociales y económicos que adquieren la calidad de fundamentales, cuando han sido amenazados o vulnerados por la acción u omisión de cualquier autoridad pública. 
Este libro forma parte del acervo de la Biblioteca Jurídica Virtual del Instituto de Investigaciones Jurídicas de la UNAM

e) La jurisprudencia de la Corte Constitucional de Colombia se transforma entonces en un criterio que guía las actuaciones de las autoridades públicas en general, en aras de evitar la amenaza o vulneración de cualquier garantía o derecho fundamental; igualmente permite que tanto estas autoridades como los particulares en general, puedan hacer adecuadas interpretaciones de la Carta Política frente a las leyes y normas que componen el sistema jurídico en general. Sus sentencias son verdaderos hitos que fortalecen al precedente judicial, y cada vez más son tomadas en cuenta como parte de las fuentes formales del derecho a nivel mundial.

f) La Corte Constitucional ha reconocido que hacen parte de los derechos objeto de protección constitucional mediante la acción de tutela, aquellos que aunque fueron concebidos inicialmente como de carácter prestacional, resultan ser auténticos derechos fundamentales de aplicación inmediata, porque su núcleo esencial mínimo no puede ser negociable y conforme con éste se confieren derechos de carácter subjetivo, más aún cuando se trata de un derecho fundamental de sujetos en condiciones de indefensión, ello independientemente de los demás instrumentos que para su protección emplee el Estado. Tal es el caso del derecho fundamental a la vida, a la salud, la integridad física, a la familia, al mínimo vital, a la vivienda, etcétera.

g) Cuando se ponen de presente situaciones de flagrante violación de los derechos fundamentales por parte de las autoridades públicas, especialmente en el caso de las personas en estado de vulnerabilidad o debilidad manifiesta, la Corte Constitucional puede declarar la existencia de un estado inconstitucional de las cosas. Con esta radical medida se busca que los organismos responsables de otorgar dicha protección tomen aquellos correctivos adecuados para salvaguardar estos derechos. 
Este libro forma parte del acervo de la Biblioteca Jurídica Virtual del Instituto de Investigaciones Jurídicas de la UNAM

\title{
LA COLISIÓN DE LOS PRESUPUESTOS DE EGRESOS CON EL CONTEXTO INTERNAGIONAL
}

\author{
Beatriz MONRROY LÓPEZ*
}

\begin{abstract}
SUMARIO: I. Introducción. II. Los efectos de la globalización en los Presupuestos de Egresos. III. Los retos del Presupuesto de Egresos frente a la globalización. IV. Conclusión. V. Bibliografia.
\end{abstract}

\section{INTRODUCGIÓN}

El artículo 31, fracción IV, de la Constitución Política de los Estados Unidos Mexicanos impone el deber social a los mexicanos de contribuir al gasto público mediante el pago de contribuciones, dicho gasto está encaminado a satisfacer las necesidades colectivas, los objetivos inherentes a la utilidad pública o a un interés social.

Las contribuciones son una de las principales fuentes de ingresos con que el Estado pretende cumplir los fines que le impone la Constitución Política de los Estados Unidos Mexicanos, por su parte, el Presupuesto de Egresos es el instrumento con el que se hace la distribución de dichos recursos económicos para ser aplicados a los programas o rubros creados para cumplir con esos fines.

El medio para satisfacer las necesidades es el recurso económico y la forma para reflejar las prioridades que deben atenderse ante la limitación de estos, es el Presupuesto de Egresos. Este instrumento constituye el mecanismo que permite satisfacer las necesidades sociales. Gracias a los recursos económicos que percibe el Estado y su forma de distribuirse éste, tiene los medios para proveer de servicios públicos a sus ciudadanos, por lo que su uso racional y cuidadoso puede impulsar la consolidación del crecimiento económico mediante la construcción y operación de escuelas, hospitales,

* Doctora en derecho y globalización, maestra en derecho y licenciada en derecho por la Universidad Autónoma del Estado de Morelos, catedrática de la Facultad de Derecho y Ciencias Sociales de la misma Universidad y abogada postulante. 
Este libro forma parte del acervo de la Biblioteca Jurídica Virtual del Instituto de Investigaciones Jurídicas de la UNAM

carreteras, combate a la pobreza, salud y seguridad. Sin dichos recursos económicos sería imposible alcanzar el desarrollo humano.

Sin embargo, en la práctica el presupuesto de egresos es ineficaz para cumplir con su función pública y con ello satisfacer las necesidades básicas de sus ciudadanos, por lo tanto, sigue existiendo pobreza, así como omisión, demora o deficiente prestación de servicios públicos, lo que merma el desarrollo humano.

Las causas que han propiciado esta ineficacia las encontramos en los contextos nacional e internacional. Bajo esta premisa, destacamos algunas políticas económicas y financieras que los principales organismos internacionales en la materia han previsto a efecto de mantener una estabilidad en las finanzas y cómo esto ha influido para que México adopte las medidas pertinentes en su actividad financiera para cumplir con los lineamientos constituidos, su desarrollo e impacto en la consecución de los fines del Estado.

Además, se expone que los efectos de la globalización no son las únicas causas generadoras del aumento de la desigualdad social, ya que también se evidencia cómo ésta se ha intensificado entre otras causas por la manera en que México ejecuta el gasto público; así, se concluye con los retos que enfrenta la administración pública y algunas alternativas que pueden propiciar el bienestar social a través de la adecuada distribución y control del erario público.

\section{LOS EFECTOS DE LA GLOBALIZACiÓN EN LOS PRESUPUESTOS DE EGRESOS}

Es sabido que las demandas sociales son ilimitadas y los recursos públicos restringidos, es por ello que la restricción económica hace necesaria la elaboración del presupuesto de egresos de manera óptima, la cual puede llevarse a cabo de acuerdo a dos técnicas: ${ }^{1}$

1. La determinación del gasto. Dicha determinación debe efectuarse considerando:

a) El nivel de servicios públicos deseados por la población.

b) La magnitud del producto que debe ser transferido de unas personas a otras para obtener el nivel de equidad deseado.

1 Turner Barragán, Ernesto Henry et al., El modelo de desarrollo económico de México y Taiwán, México, Ediciones y Gráficos Eón, 2007, pp. 113 y 114. 
Este libro forma parte del acervo de la Biblioteca Jurídica Virtual del Instituto de Investigaciones Jurídicas de la UNAM

c) La etapa del ciclo en que se encuentra la economía y las dificultades coyunturales que se enfrentan.

d) Los recursos que desean comprometerse al desarrollo con el fin de elevar la productividad y atender los problemas estructurales y de largo plazo del país.

2. Su asignación. Debe estar determinada por una rigurosa evaluación de proyectos y por una selección de alternativas que ofrezcan a la comunidad mayor bienestar y menor costo social.

Sin embargo, tales técnicas son insuficientes para evitar la ejecución ineficiente del gasto público. En los últimos años, México ha sido escenario de los efectos de la globalización. En el aspecto económico ha participado en el fenómeno de la liberalización económica, el intercambio de información a través del uso de datos, bienes y servicios, cultura, medio ambiente, entre otros, acortando las distancias existentes entre los diversos países, pero además, ha contraído una serie de deberes frente al ámbito internacional.

A partir del 2008, nuestro país forma parte del Grupo G-20, un organismo internacional integrado por 19 países y la Unión Europea, que se reúne de manera anual a efecto de atender temas relacionados con la actividad financiera de los diversos países, su crisis, estabilidad, propuestas, entre otros. Además de los miembros, asisten otros países invitados y organismos internacionales como el Banco Central Europeo, el Fondo Monetario Internacional, el Banco Mundial, representantes del Consejo de Estabilidad Financiera, Organización de las Naciones Unidas, autoridades monetarias y económicas de la Unión Europea, Organización para la Cooperación y Desarrollo Económico, Organización Internacional del Trabajo y la Organización Mundial para el Comercio. ${ }^{2}$

Derivado de la crisis económica acaecida en 1982, en la que México anunció su imposibilidad para cumplir con el pago de la deuda externa, existe una preocupación en la política económica basada en la lucha contra la inflación, recuperación del crecimiento económico y la introducción de reformas estructurales tendientes a la asignación de los recursos guiados por los criterios de mercado. El Fondo Monetario Internacional se convirtió en una agencia del manejo de la deuda y ha influido en los últimos años en

2 Abeles, Martín y Kiper, Esteban, "El G-20 y el rol de la Argentina”, Serie Aportes, Argentina, núm. 9, 2010, pp. 7 y 8. 
Este libro forma parte del acervo de la Biblioteca Jurídica Virtual del Instituto de Investigaciones Jurídicas de la UNAM

nuestro país para definir los perfiles de los programas de estabilización y ajuste estructural. ${ }^{3}$

Dicho organismo atribuye a las políticas económicas gubernamentales las causas de los desequilibrios e inestabilidades internas, por lo tanto, considera que para lograr la estabilidad de un país, sus políticas deben apoyarse en cuatro ámbitos, ${ }^{4}$ a saber:

a) Política fiscal: el principal objetivo es tener un déficit público que no rebase el 3\% del Producto Interno Bruto (PIB). Lo anterior se consigue con la disminución del gasto público, no así con el incremento de la carga tributaria. Aunado a lo anterior, deben eliminarse las empresas públicas con déficit y los subsidios que pretendan estabilizar artificialmente ciertos precios.

b) Política monetaria y crediticia: basada en la fijación de topes en la emisión de moneda para sostener políticas expansivas de gasto por la necesidad de elevar el bienestar social; el incremento de tasas de interés que estimule el ahorro, logrando un mejor criterio de asignación de los recursos al seleccionar proyectos que tengan una mayor rentabilidad.

c) Política cambiaria: a través de la devaluación de la moneda nacional a corto plazo siguiendo el criterio de la paridad de poder de compra, cuyos efectos serían la reducción de la demanda global y la reasignación de los recursos productivos hacia el sector externo en mediano plazo.

d) Política salarial: frenar el crecimiento de los salarios reales en mediano y largo plazo, los cuales deben ser reajustados atendiendo a la productividad, rechazando la indexación de los salarios con el nivel y ritmo de la inflación, e incluso, concibe la idea de que el Estado debe poner el ejemplo al limitar el alza de los salario de sus empleados.

En tanto que los cambios estructurales están encaminados a reducir la intervención del Estado en la economía nacional, apuntando hacia la iniciativa privada nacional y extranjera.

Luego entonces, cuando México tuvo la crisis de 1982, en la que se declaró insolvente para pagar la deuda externa, tuvo que comprometerse con el Fondo Monetario Internacional con el fin de tener acceso a nuevos présta-

3 Chávez Ramírez, Paulina Irma, Las cartas de intención y las políticas de estabilización y ajuste estructural de México: 1992-1994, México, UNAM, Instituto de Investigaciones Económicas, 1996, p. 7.

4 Ibidem, pp. 26-28. 
Este libro forma parte del acervo de la Biblioteca Jurídica Virtual del Instituto de Investigaciones Jurídicas de la UNAM

mos, sometiendo su política económica al Programa Inmediato de Reordenación Económica (PIRE). Así, el 10 de noviembre de 1982, el licenciado Jesús Silva-Herzog F., en ese entonces secretario de Hacienda y Crédito Público, así como el licenciado Carlos Tello Macías, director general del Banco de México, anunciaron en una conferencia de prensa la firma de una Carta de Intención con el Fondo Monetario Internacional. ${ }^{5}$

La carta exponía la crisis económica que venía acogiendo nuestro país desde 1981, lo que generó la elevación del gasto público por encima de lo programado, el endeudamiento externo del sector público y la consecuente introducción de medidas de ajuste económico a mediados de 1981, que se tradujeron en la reducción del gasto público programado, el aumento de los aranceles, el tipo de interés interno, precios y tarifas, afectando principalmente productos de consumo básico como la tortilla, el pan, la gasolina, electricidad y combustibles; lo que obligó al gobierno a crear políticas de nacionalización de los bancos privados del país, desentivar las importaciones y movimientos especulativos del capital, entre otros. Medidas que se adecuarían conforme lo aconsejaran las autoridades nacionales e internacionales. ${ }^{6}$

En los últimos años, México ha tenido el interés por ajustar sus políticas económicas a las medidas que el Fondo Monetario Internacional considera necesarias para lograr el equilibrio y estabilidad financiera, lo que indudablemente impacta en el presupuesto de egresos, puesto que, uno de los elementos que considera el órgano internacional para lograrlo consiste en que el déficit presupuestario no debe rebasar el 3\% del Producto Interno Bruto, lo que se obtiene a través de la disminución del gasto público.

En esta perspectiva, la globalización ha influido en la reducción del gasto público. Desde el mandato de los entonces presidentes Vicente Fox Quezada y Felipe Calderón Hinojosa, quienes a mitad de su sexenio realizaron adecuaciones a sus proyectos de presupuestos de egresos tendientes a su disminución, incluso durante el mandato presidencial del licenciado Enrique Peña Nieto, quien ha justificado la reducción del gasto público a un ajuste preventivo a consecuencia de la presión del entorno global como lo es el tipo de cambio. ${ }^{7}$

5 Secretaria de Hacienda y Crédito Público, México y el FMI: la carta de intención, disponible en: http://revistas.bancomext.gob. $m x / r c e /$ magazines/665/11/RCE10.pdf.

6 Idem.

7 Auditoría Superior de la Federación, Análisis del Informe de Avance de Gestión Financiera 2016, agosto 2016, disponible en: http://wrwre.asf.gob.mx/uploads/56_Informes_especiales_de_au ditoria/ANALISIS_DEL_INFORME_DE_AVANCE_DE_GESTION_FINANCIERA_2016.pdf. presupuesto de egresos asignado para el ejercicio fiscal 2017. 
Este libro forma parte del acervo de la Biblioteca Jurídica Virtual del Instituto de Investigaciones Jurídicas de la UNAM

Ante ello, el 17 de febrero de 2016 la Secretaría de Hacienda y Crédito Público, el Banco de México y la Comisión de Cambios anunciaron el ajuste del presupuesto de egresos correspondiente al ejercicio fiscal 2016, por un monto de 132.4 miles de millones de pesos. Dentro de los afectados se encontraban Petróleos Mexicanos (Pemex), gobierno federal, Comisión Federal de Electricidad (CFE) y el Instituto de Seguridad y Servicios Sociales de los Trabajadores del Estado (ISSSTE), así como un incremento de 50 puntos base en la tasa de interés interbancaria. Aunado a ello, tras la determinación de Reino Unido de no seguir perteneciendo a la Unión Europea, la Secretaría de Hacienda anunció el 24 de junio del mismo año un segundo recorte al gasto público federal, a efecto de cumplir con la meta de déficit cero y reducir el saldo histórico de requerimientos financieros del sector público (SHRFSP), afectando solamente al gobierno. ${ }^{8}$

Sin embargo, merece la atención lo correspondiente al recorte presupuestal para el ejercicio fiscal 2017, por ser el más grande de los últimos años y afectar a programas de desarrollo social, a consecuencia de la caída del ingreso petrolero y los requerimientos financieros de la deuda externa. De acuerdo al paquete económico que presentó el Secretario de Hacienda y Crédito Público ante la Cámara de Diputados el 8 de septiembre de 2016, se observa que algunos de los programas que fueron afectados con el recorte presupuestal y que inciden significativamente en el desarrollo humano, son los siguientes: ${ }^{9}$

\begin{tabular}{|l|c|}
\hline \multicolumn{1}{|c|}{ Programa } & $\begin{array}{c}\text { Recorte presupuestal } \\
\text { en MDP }\end{array}$ \\
\hline Pensión para adultos mayores (Sedesol) & 39,851 \\
\hline $\begin{array}{l}\text { Programa de adquisición de leche nacional a cargo de Liconsa } \\
\text { (Sedesol) }\end{array}$ & 1,642 \\
\hline $\begin{array}{l}\text { Programas de estancias infantiles para apoyar a madres trabajado- } \\
\text { ras (Sedesol) }\end{array}$ & 3,926 \\
\hline Comedores comunitarios (Sedesol) & 3,150 \\
\hline Programa Integral de Desarrollo Rural (Sagarpa) & 9,403 \\
\hline Programas Escuelas de Tiempo Completo (SEP) & 10,561 \\
\hline Programa de inclusión y alfabetización digital (SEP) & 1,642 \\
\hline Programa nacional de becas (SEP) & 14,152 \\
\hline Formación y certificación para el trabajo (SEP) & 2,718 \\
\hline
\end{tabular}

\footnotetext{
8 Idem.

9 Véase "El recorte de 2016 en cinco gráficas", El Universal, disponible en: http://interac tivo.eluniversal.com.mx/online/datos/presupuesto15.
} 
Este libro forma parte del acervo de la Biblioteca Jurídica Virtual del Instituto de Investigaciones Jurídicas de la UNAM

\begin{tabular}{|l|c|}
\hline \multicolumn{1}{|c|}{ Programa } & $\begin{array}{c}\text { Recorte presupuestal } \\
\text { en MDP }\end{array}$ \\
\hline Atención a la demanda para la educación para adultos (INEA) & 3,145 \\
\hline Investigar y perseguir los delitos del orden federal (PGR) & 9,788 \\
\hline $\begin{array}{l}\text { Fomento de la cultura de la participación ciudadana en la preven- } \\
\text { ción del Delito (Secretaría de Gobernación) }\end{array}$ & 210 \\
\hline Programa de tratamiento de aguas residuales (Sermanat) & 2,463 \\
\hline $\begin{array}{l}\text { Investigación y desarrollo tecnológico en salud (Secretaría de } \\
\text { Salud) }\end{array}$ & 2,057 \\
\hline $\begin{array}{l}\text { Prevención y atención de VIH/Sida y otras ITS (Secretaría de } \\
\text { Salud) }\end{array}$ & 373 \\
\hline Seguro Popular (Secretaría de Salud) & 74,437 \\
\hline $\begin{array}{l}\text { Reducción de enfermedades prevenibles por vacunación (Secre- } \\
\text { taría de Salud) }\end{array}$ & 1,880 \\
\hline Prospera programa de inclusión social (Secretaría de Salud) & 6,210 \\
\hline Programa de Apoyo al Empleo PAE (STPS) & 2,027 \\
\hline
\end{tabular}

Ello significa que los sectores de salud, educación, trabajo, seguridad pública, entre otros, limitarán los servicios prestados en tales rubro, siendo la población la que resentirá la disminución o privación en su desarrollo humano, al restringirse los beneficios que pudiera representar el programa en el aspecto económico, en especie, inversión o gasto corriente.

Como he mencionado, la política fiscal implica que el déficit presupuestario no debe exceder del 3\%, por lo tanto, propone que el gasto público se vea disminuido, sin embargo: ¿qué criterio debe tomarse en cuenta para adoptar la decisión de la reducción del presupuesto de egresos a un rubro especifico? Tales criterios descansan en la potestad discrecional del Ejecutivo Federal, quien de acuerdo a su facultad de dirigir la rectoría económica del país decide el monto y sector que debe resentir la modificación, de ahí que no hay mayor argumento que justifique, como en el caso concreto, que son los programas de desarrollo social los que deben participar en el recorte presupuestal y no así otras dependencias que no tienen tanto impacto en tal materia.

Ante ello, no es loable que el Ejecutivo Federal omita ponderar las necesidades sociales con criterios que permitan consolidar el desarrollo humano de la persona. Si bien es cierto, el recorte presupuestal que se viene contemplando para el ejercicio fiscal 2017, en comparación con el anterior donde fueron los gastos corrientes del gobierno y otros sectores los que se vieron afectados, y cuya naturaleza impacta en menor dimensión en el desarrollo de la persona, está justificado en la presión que ejercen los efectos 
Este libro forma parte del acervo de la Biblioteca Jurídica Virtual del Instituto de Investigaciones Jurídicas de la UNAM

de la globalización, es necesario señalar por otra parte que los organismos internacionales no determinan cuáles son los sectores que deben ajustar los gastos, luego entonces, esa decisión recae en el Ejecutivo Federal quien no toma en cuenta las necesidades apremiantes de la sociedad para definir los ajustes presupuestales.

Sólo para ejemplificar mencionamos a la Cámara de Diputados, cuyo presupuesto de egresos asignado para el ejercicio fiscal 2017 asciende aproximadamente a 8,051,000,487 millones de pesos, en comparación con el ejercicio 2016 en donde se aprobaron 7,559,432,185 millones de pesos, es decir, cada ejercicio fiscal aumentan sus gastos públicos sin aplicar medidas de austeridad. ${ }^{10}$ Por otra parte, de acuerdo al primer trimestre del ejercicio fiscal 2015, los ramos administrativos de gobernación, función pública y salud tuvieron un sobre-ejercicio total de 494.2 millones de pesos, en tanto que, se presentaron los siguientes subejercicios: ${ }^{11}$

a) Ramo 11 tuvo un subejercicio de 163.4 millones de pesos.

b) Ramo de 9 (telecomunicaciones y transporte) con 10.4 millones de pesos.

c) Ramo 20 (desarrollo social) con 122.8 millones de pesos.

d) Energía con 8.8 millones de pesos.

Si bien es cierto, un sobreejercicio puede compensarse con los subejercicios, también lo es que ello no subsana el impacto que generó al sector social e incluso a nuestro marco normativo. En primer lugar, el gasto que excede el presupuesto público autorizado evidencia que no existe una correcta planeación y que el artículo 26 constitucional que vincula a la rectoría económica del país al Plan Nacional de Desarrollo es letra muerta. Además, no existen parámetros que puedan justificar que el aumento obedeció a un gasto justificado o necesario, afectando al erario público e incluso transgrediendo los principios de racionalidad, economía y eficiencia del gasto público.

Por otro lado, cuando hablamos que el subejercicio se compensa con el sobreejercicio, esto no resuelve la afectación que se generó en la calidad de vida de las personas o en su desarrollo humano, pues necesariamente se dejaron de asignar los recursos públicos a los fines para los cuales fueron auto-

10 Cfr. Presupuestos de Egresos de la Federación para los ejercicios fiscales 2016 y 2017, disponible en: http://wrerrediputados.gob.mx.

11 Centro de Estudios de las Finanzas Públicas, Gasto presupuestario del sector público al primer trimestre, 2015, junio de 2015, disponible en: http://wrere.cefp.gob.mx/publicaciones/documento /2015/junio/cefp0122015.pdf. 
Este libro forma parte del acervo de la Biblioteca Jurídica Virtual del Instituto de Investigaciones Jurídicas de la UNAM

rizados, menoscabo que no puede retrotraerse con la simple compensación que se haga al presupuesto de egresos.

Bajo este contexto, la inadecuada administración de los recursos públicos que hacen sus ejecutores, la omisión de ponderar y ejecutarlos racionalmente, ha expuesto a los programas y sectores sociales más vulnerables a la insatisfacción de las demandas sociales, los cuáles no pueden ser resarcidos.

Adicional al recorte presupuestal, como efecto de la globalización, a nivel nacional tenemos el problema de la ejecución ineficiente del gasto público. Sólo para ejemplificar, según el informe de resultado de la Fiscalización Superior de la Guenta Pública 2014, encontramos las siguientes inconsistencias en el gasto federalizado: ${ }^{12}$

a) 9,306.1 millones de pesos de gasto público ejercido que no cuentan con documentación comprobatoria.

b) 8,389.6 millones de pesos en recursos ejercidos por conceptos que no cumplen con los objetivos específicos del fondo o programa.

c) 4,653.6 millones de pesos de recursos públicos transferidos a cuentas bancarias diversas a las autorizadas.

d) El pago improcedente o en exceso en cantidad de 4,568.9 millones de pesos.

e) Recursos no devengados, ejercidos o reintegrados a la Tesorería de la Federación (Tesofe) en cantidad de 28,508.7 millones de pesos.

Destacando que el gasto federalizado descansa en los rubros de educación federal (educación para adultos mayores, infraestructura educativa, matriculación), desayunos escolares, salud, seguridad pública, ejecución de obras en poblaciones con pobreza extrema. Sin soslayar que existen otros problemas como la falta de control en el padrón de beneficiarios, lo que generó duplicidad en el apoyo entregado, o bien entrega a personas que ya fallecieron; ausencia de supervisión de la federación respecto de los programas, para garantizar la correcta aplicación de los recursos transferidos; la falta de reglas de operación o lineamientos específicos que regulen la asignación, ejercicio y comprobación de los recursos, sólo por mencionar algunos. ${ }^{13}$

El impacto que trae consigo el recorte presupuestal y la ejecución ineficiente del gasto público se ve reflejado en el grado de satisfacción de los bienes y servicios. Si el Estado limita los recursos públicos ante una excesiva

12 Auditoria Superior de la Federación, Informe General Cuenta Pública 2014, p. 96, disponible en: http://wrwreasf.gob.mx/Trans/Informes/IR2014i/Documentos/InformeGeneral/ig2014.pdf.

13 Ibidem, pp. 95, 100, 110 y 111. 
Este libro forma parte del acervo de la Biblioteca Jurídica Virtual del Instituto de Investigaciones Jurídicas de la UNAM

demanda social, sin que estos sean satisfechos, trae consigo otros problemas, como la exclusión social y pobreza, a consecuencia de la ausencia de salud, educación, empleo, vivienda, cultura, obras públicas, sólo por mencionar algunos.

Luego entonces, entre menor sea el recurso público que se asigne a seguridad pública o esté destinada desproporcionadamente a gasto corriente, seguirán persistiendo los problemas de inseguridad; en el sector de salud, enfermedades que eran prevenibles, traerán como consecuencia una demanda especializada de equipos, medicamentos, personal, lo que impactaría no sólo en el incremento del gasto, sino además, en el bolsillo de las personas, al tener que erogar cantidades de dinero no contempladas por la carencia de medicamentos, adicionalmente, afectaría su desempeño laboral o el desempeño académico según sea el tipo del padecimiento al disminuir las capacidades para responder adecuadamente a las exigencias de la actividad.

Ante ello nos preguntamos: ¿qué relación tiene la pobreza o exclusión social con la globalización? En tanto exista miseria o escases de recursos económicos, aparecerán otros problemas como la corrupción, debido a que ésta imposibilita su control de manera eficaz al carecer de los recursos económicos para combatirla eficientemente, generando un deseo mayor de eludir las normas o bien, existiendo un sistema jurídico que lejos de servir como mecanismo preventivo y coercitivo promueva la corrupción, lo cual genera efectos negativos sobre el crecimiento y la eficiencia económica. ${ }^{14}$

Respecto al tema, el índice nacional de la corrupción del 2015, publicado por Transparencia Internacional (TL) - organización no gubernamental integrada por un sector civil, privado y gobierno dedicado a combatir la corrupción - dio a conocer los resultados de la percepción de la corrupción del 2015. De una escala que va de cero a cien (siendo la escala cero el más alto nivel de corrupción y 100 el más bajo), nuestro país está posicionado en el último lugar entre los 34 países miembros la Organización para la Cooperación y el Desarrollo Económicos (OCDE) con 35 de puntuación al igual que en el 2014, y como miembro del grupo G-20 está en el lugar 17 de los 19 países que lo conforman. ${ }^{15}$

Su impacto negativo en la economía puede explicarse, entre otras formas, con el control que ejerce el Banco Mundial a través de los informes que

14 Krugman, Paul R., Economía internacional. Teoría y politica, 9a. ed., Madrid, Pearson Educación, 2012, pp. 640 y 672.

15 Transperency International España, Índice de percepción de la corrupción 2015 (IPC), disponible en: http://transparencia.org.es/wp-content/uploads/2016/01/comparacion_ipc2007_a_2015.pdf. 
Este libro forma parte del acervo de la Biblioteca Jurídica Virtual del Instituto de Investigaciones Jurídicas de la UNAM

emite respecto de la factibilidad para hacer negocios en los países miembros de la OCDE, una especie de análisis que se lleva a cabo a petición de los gobiernos con el objeto de que las empresas puedan detectar la viabilidad de invertir en los países en vía de desarrollo. Este análisis toma en cuenta 10 aspectos de regulación en trámites, tiempo, costo y capital mínimo exigido para: abrir una empresa, construir una bodega, transmitir una propiedad, resolver un juicio mercantil; la calidad de regulación en construcción y su implementación, en la administración de la tierra y los procesos judiciales; acceso al crédito, protección de inversores, pago de impuestos, comercio fronterizo, cumplimiento de contratos y resolución de insolvencias. ${ }^{16}$

Podemos entender que la burocratización de trámites para hacer negocio por parte de los operadores del sistema, obstaculizan y hacen tedioso el procedimiento que deben seguir los empresarios con la intención de obtener sobornos, consecuentemente los inversionistas optan por buscar otros lugares con mayor facilidad para obtener autorizaciones de operatividad, de tal manera que no se retrase indefinidamente su función, es decir, hay un abandono en la inversión.

Lo mismo acontece tratándose de la impartición de justicia, los inversionistas buscan confiabilidad en las instituciones judiciales que resuelvan de manera pronta y expedita los litigios, de no ser así, pierden el interés de traer su capital ante la inminente desconfianza de poder salvaguardar sus intereses en caso de presentarse conflictos en la interpretación y aplicación de sus actos jurídicos.

Por cuanto a seguridad pública, un país que no provea confianza y protección por parte de sus instituciones y a sus ciudadanos tampoco lo hará a los inversionistas quienes optaran por acudir a países que le brinden esa confiabilidad tanto en lo patrimonial como lo personal.

Por lo anterior, existe interés de México para ser evaluado y despuntar como un país confiable para invertir; sin embargo, la posición negativa en que se coloca México, con resultados de corrupción, pobreza y déficit presupuestario superior al 3\%, impacta negativamente en temas como la estabilidad económica y financiera del país, lo que resulta relevante para los organismos internacionales como lo es el Grupo G-20 y el Fondo Monetario Internacional, debido a que la falta de competitividad económica genera problemas de inflación y de impago de la deuda externa lo que afecta a las economías globales.

16 Grupo Banco Mundial, Doing bussines en México 2016. Midiendo la calidady la eficiencia de la regulación, 6a. ed., Washington, Banco Internacional para la Reconstrucción y el Desarrollo, 2016, p. 2. 
Este libro forma parte del acervo de la Biblioteca Jurídica Virtual del Instituto de Investigaciones Jurídicas de la UNAM

El escenario anterior es sólo un esbozo que refleja el impacto que han tenido los organismos internacionales sobre las políticas y reformas estructurales de la actividad financiera en México; sin embargo, ello no ha servido para enfrentar el principal problema que se tiene en México, tal es el caso de la desigualdad social y el combate a la pobreza.

\section{Los Retos Del Presupuesto De Egresos FRente A LA GLOBALIZACIÓN}

Dentro de los principales problemas que enfrentan los tres niveles de gobierno en México son la crisis económica, inseguridad, corrupción, descrédito de los partidos políticos, la incapacidad para responder las demandas sociales, entre otros, lo que propicia el nacimiento de diversos movimientos sociales que exigen la satisfacción de sus demandas y con ello el interés de involucrarse activamente en la gestión pública, generando un estado en transición al pasar de gobernabilidad a gobernanza.

$\mathrm{Si}$ a los anteriores problemas añadimos el hecho de que las sanciones administrativas y de carácter penal previstas en nuestro sistema normativo no permiten prevenir, y aún menos reducir la problemática, lo que conlleva a la reiteración de conductas que atentan contra la correcta aplicación del gasto público.

Dentro de las experiencias que ha tenido la Auditoria Superior de Fiscalización de la cuenta pública, encontramos que en la revisión al ejercicio fiscal 2014 no existe la precisión de un informe que destaque las denuncias presentadas por la comisión de posibles delitos o el inicio de procedimientos administrativos, su justificación se apoya en que debe llevarse a cabo cuando tenga los elementos constitutivos del delito según lo previsto por el numeral 31 de la Ley de Fiscalización y Rendición de Cuentas de la Federación. En tal sentido, desde la revisión de las cuentas públicas de 1998 hasta el 2013 han sido presentadas 664 denuncias de hechos, de las cuales 607 están en trámite - sin contar con datos de que haya operado la figura jurídica de la prescripción del delito-, 9 están en reserva, 21 consignadas, 15 en amparo y en 12 no se ejerció la acción penal. ${ }^{17}$

Indudablemente, al no aplicarse las sanciones a los infractores es notorio que las faltas cometidas por los funcionarios públicos persistirán ante el

17 Cfr. Unidad de Evaluación y Control de la Cámara de diputados LXIII Legislatura, Datos básicos del Informe de Resultado de la Fiscalización Superior de la Cuenta Pública 2014, febrero 2016, disponible en: http://wrww3.diputados.gob.mx/camara/001_diputados/008_comisioneslx/001_ordinarias/042_vigilancia_de_la_auditoria_superior_de_la_federacion/012_unidad_de_ evaluacion_y_control, p. 14. 
Este libro forma parte del acervo de la Biblioteca Jurídica Virtual del Instituto de Investigaciones Jurídicas de la UNAM

conocimiento de las deficiencias que tiene los operadores o el sistema jurídico mexicano, para hacer cumplir la norma quedando impugne el delito o la responsabilidad administrativa en que pudieron incurrir.

Por otra parte, México cuenta con diversos instrumentos que obligan al Ejecutivo a rendir cuentas de su desempeño, no obstante, las labores de fiscalización han sido insuficientes para lograr un verdadero control en el gasto público, entre otras cosas porque los responsables de su ejecución únicamente verifican el uso de los recursos, pero no evalúan qué tan eficiente fue la utilización de los mismos, el impacto o resultado que obtuvieron las políticas y programas públicos, o bien, no existen las directrices necesarias para su correcta aplicación y vigilancia, consecuentemente, existe dificultad para tener un panorama general del desempeño del gasto y los funcionarios públicos. ${ }^{18}$

El sistema fiscal no escapa de esta crisis, es notorio que está caracterizado por una recaudación muy baja a consecuencia del comercio informal, la elusión y evasión fiscal; un esquema con múltiples exenciones en donde grandes empresarios se han vistos beneficiados por temor a perder las inversiones; la condonación de impuestos que ha venido efectuando de manera discrecional la Secretaría de Hacienda y Crédito Público a grupos empresariales; una participación desbalanceada por parte de los niveles de gobierno en cuanto a su recaudación y distribución de recursos, de modo que el gasto público resulta insuficiente para financiar las necesidades de salud, educación, servicios públicos entre otros.

Ejemplo de lo anterior, es que para el 2014, de los países miembros de la Organización para la Cooperación y el Desarrollo Económico (OCDE), México sólo percibía el 19.5\% de recaudación tributaria. De acuerdo a dicha organización, las causas que contribuyen de manera positiva o negativa en la percepción de ingresos son: ${ }^{19}$

a) Reformas que controlen la inflación e imponga una disciplina fiscal (incremento de la recaudación, reducción del gasto público, implementación de tecnología, reducción de exenciones e incentivos fiscales).

b) La informalidad.

c) La ubicación geográfica, los recursos naturales, la agricultura.

18 Guerrero Amparán, Juan Pablo, Transparencia presupuestaria en cinco países de América Latina, resultados en 2001, México, Porrúa, 2004, p. 76.

19 Centro de Política y Administración Tributaria de la OCD, et al., Estadísticas tributarias en América Latina y el Caribe 1990-2014, OECD Library, 2016, pp. 41, 44 y 45. 
Este libro forma parte del acervo de la Biblioteca Jurídica Virtual del Instituto de Investigaciones Jurídicas de la UNAM

d) El nivel de educación.

e) La inclusión de las mujeres en el mercado laboral.

f) La fijación de precios de transferencia.

g) El nivel de corrupción y la voluntad de pagar las contribuciones.

En tal sentido, la recaudación en México dista del gasto público. Es notorio que en cada ejercicio fiscal se contempla una estimación de los ingresos a percibir, sin embargo, está apoyado en gran medida de la base trabajadora, del Impuesto al Valor Agregado, de los derechos, entre otros, faltando el interés de la autoridad fiscal por combatir el comercio informal, pese a que se han estructurado diversas reformas que incentivan la formalidad e incluso el Código Fiscal Federal que le delega facultades para detectar a los evasores fiscales y obligarlos al pago de los impuestos. Por otra parte, tenemos regímenes que privilegian a grandes empresarios como el opcional para grupo de sociedades o en su defecto, que condonan el pago de tributación como un incentivo a los morosos o infractores para que se pongan al corriente. ${ }^{20}$

Desde esta perspectiva, el sistema normativo que regula la recaudación tributaria, el gasto público, así como la auditoria de fiscalización y rendición de cuentas, resultan insuficientes para lograr un estado de bienestar, de modo que, al verse limitados los ingreso frente a un número desmedido de demandas sociales, es notorio que el Estado no puede satisfacer todas las necesidades e incluso las más apremiantes de la sociedad, conduciéndonos a enfrentarnos a un problema de ingobernabilidad, al evidenciarse las siguientes particularidades: ${ }^{21}$

a) Mal manejo del sector Público. Representado por una recaudación desigual de ingresos, mal manejo y control del gasto público, poca inversión a los fondos públicos y debilidad en los diseños de las políticas públicas para abatir los problemas sociales, lo que genera déficits fiscales y erosión progresiva de la capacidad del Estado para abastecer los servicios económicos y sociales.

b) Carencia de un marco legal y/o su aplicación arbitraria.

c) Falta de trasparencia en la toma de decisiones.

20 Secretaría de Hacienda y Crédito Público, Programa de Regularización de Adeudos "Ponte al Corriente". Transitorio tercero de la Ley de Ingresos de la Federación para el Ejercicio fiscal de 2013, disponible en: http://wrere.sat.gob.mx/transparencia/rendicion_cuentas/Documents/Informe_PontealCorriente2013_271213.pdf.

21 Ochoa Antich, Nancy, Gobernabilidad versus democracia pluralista, Ecuador, Ediciones Abya-Yala, 2003, pp. 64 y 65. 
Este libro forma parte del acervo de la Biblioteca Jurídica Virtual del Instituto de Investigaciones Jurídicas de la UNAM

No sólo la ingobernabilidad es el único problema que se ha manifestado en gran escala en la actualidad, ello ha sido resultado en parte por el incremento de la desigualdad social lo que ha propiciado un mayor estado de insatisfacción en las personas persistiendo los índices de pobreza.

Frente a estos conflictos, el fenómeno de la globalización no es la excepción al momento de considerar las causas generadoras de la pobreza. No podemos negar que dentro de los beneficios que ha traído consigo encontramos: ${ }^{22}$

a) El crecimiento económico gracias a la apertura del comercio internacional.

b) El aumento de la estimativa de vida y el nivel muy superior al antes obtenido.

c) Para algunos, trabajar en las fábricas es considerado preferible a permanecer en el campo.

d) La reducción de la sensación de aislamiento entre los habitantes de los distintos países con el uso de Internet, así como la adquisición de nuevos saberes.

e) Puede existir una afectación en empresas privadas o públicas protegidas, pero también permite la obtención de productos a menores costos.

f) Fomenta la introducción de nuevas tecnologías, el acceso a nuevos mercados y la creación de nuevas industrias.

g) La creación de nuevas instituciones jurídicas, entre otros.

No obstante, no se han visto materializados los aspectos positivos que prometía la institución de la globalización, de ahí que también encontramos aspectos negativos, tales como: ${ }^{23}$

a) La distribución inequitativa de la riqueza que no ha permeado en el combate a la pobreza, la cual ha aumentado considerablemente.

b) No ha garantizado la estabilidad económica de los países en vías de desarrollo.

c) Hay una descendencia de las rentas y niveles de vida.

d) El beneficio de la flexibilización de los bancos occidentales sobre el control de los mercados de capitales en América Latina y Asia, dejó

22 Stiglitz E., Joseph, El malestar en la globalización, trad. de Carlos Rodríguez Braun, Madrid, Taurus, 2002, pp. 35 y 36.

23 Ibidem, pp. 37-44. 
Este libro forma parte del acervo de la Biblioteca Jurídica Virtual del Instituto de Investigaciones Jurídicas de la UNAM

divisas colapsadas y debilitó los sistemas bancarios al permitirse la salida abrupta del dinero.

e) El medio ambiente ha sido afectado considerablemente.

f) Los procesos políticos han sido corrompidos; sólo por mencionar algunos.

Si bien, los problemas no son nuevos, lo cierto es que la globalización no ha permitido su afianzamiento, lo que ha traído consigo diversas manifestaciones en oposición al sistema, sobre todo por el control que ejerce el Fondo Monetario Internacional y el Banco Mundial sobre los países miembros, a tal grado de afectar su soberanía, su actividad presupuestal y financiera así como el sistema jurídico aplicable, en general todo el bienestar social.

Es innegable que gracias a la globalización actualmente podemos hablar de derechos humanos, interés legítimo, control de convencionalidad; en el aspecto financiero hemos incorporado nuevas maneras de distribuir el gasto público como lo referimos cuando hablamos del presupuesto de egresos del entonces Ejecutivo Federal cuyo titular era Vicente Fox Quezada, así como el nuevo sistema nacional anticorrupción, los recortes presupuestales, entre otros, los cuales tienen la intención de mejorar la eficiencia del gasto público y mantener un equilibro financiero.

Sin embargo, como lo afirma el economista Joseph Stiglitz, el problema no está en la globalización sino en el modo en que ésta ha sido gestionada por las instituciones económicas internacionales que han favorecido los intereses particulares de un grupo minoritario, ${ }^{24}$ de modo que se ha enfocado la globalización a aspectos económicos más que al combate a la pobreza.

Adicional a ello, los dirigentes de los países han implementado medidas favorables a sus intereses; si bien no podemos pasar por desapercibido que el Fondo Monetario Internacional incorpora como tercer medida para lograr el equilibrio financiero una política salarial en la que el Estado deba poner el ejemplo al limitar el alza de los salario de sus empleados, lo cierto es que esa medida sujeta al arbitrio de los dirigentes del país, que deciden cómo hacerlo, sin que, en efecto, desvirtúen tal criterio, siendo el salario de los más altos dirigentes el que en cada ejercicio fiscal se ve favorecido con los incrementos como más adelantes se detallará.

Luego entonces, la adopción de la medida de recorte presupuestal así como su ejecución ineficiente tiene un impacto que se refleja en el grado de satisfacción de los bienes y servicios. Si el Estado limita los recursos públicos ante una excesiva demanda social, sin que esta sea satisfecha, ello trae

24 Stiglitz E., Joseph, op. cit., p. 269. 
Este libro forma parte del acervo de la Biblioteca Jurídica Virtual del Instituto de Investigaciones Jurídicas de la UNAM

consigo otros problemas, como la exclusión social y pobreza, a consecuencia de la ausencia de salud, educación, empleo, vivienda, cultura y obras públicas.

Por ello, el punto clave para combatir los problemas sociales no está exclusivamente en los fenómenos de la globalización, sino además en la manera en que los operadores del gasto público lo distribuyen.

Luego entonces, el principal reto que enfrenta el presupuesto de egresos consiste en tener un equipo de trabajo honesto, capacitado y especializado en materia de administración, economía, derecho, política y contabilidad, para tomar decisiones acertadas.

En tal sentido, el reto que actualmente enfrenta el presupuesto de egresos frente a la globalización está en:

a) La obtención de un equipo de trabajo honesto, capacitado y especializado en materia de administración, economía, derecho, política y contabilidad, para tomar decisiones acertadas en cuanto a la distribución y ejecución del gasto público.

b) Un órgano de fiscalización autónomo que se encargue de la auditoria y persecución de los delitos e francciones relacionadas con la ejecución del gasto público.

c) Cuerpos normativos que regulen acciones correctivas y no sólo preventivas en cuanto a la fiscalización y control del gasto público.

d) Cuerpos normativos que establezcan lineamientos para los operadores del gasto público que ponga limites a los criterios discrecionales para recortar el gasto público.

e) La descentralización del poder a través de la reducción de la sobrecarga de las funciones del gobierno que facilite el acceso a la toma de decisiones con la participación de los sectores sociales incluyendo los niveles más bajos del gobierno tanto en la designación, ejecución, control y vigilancia del gasto público, entre otros.

\section{GONCLUSIÓN}

Las carencias económicas, escasas fuentes de trabajo, o en su caso, con una remuneración insuficiente, servicios básicos como salud con grandes limitaciones, insuficiencia en la prestación de servicios públicos, inseguridad, corrupción, pérdida de credibilidad en los representantes, son sólo algunos de los factores que han generado en la ciudadanía cierta desconfianza en la vida política del país. 
Este libro forma parte del acervo de la Biblioteca Jurídica Virtual del Instituto de Investigaciones Jurídicas de la UNAM

La pobreza no se reduce a consecuencia de un cambio en las perspectivas individuales, sino de la fijación de políticas que estén encaminadas a una distribución más igualitaria de la renta y del gasto público en toda la sociedad. Sin embargo, ante ausencia del uso racional de estos recursos económicos, así como la falta de respuesta del gobierno de cubrir el mínimo de los satisfactores de la sociedad, ha permitido comprender que a nivel colectivo se puede intervenir en la toma de decisiones en aquellos asuntos que más les afecte, tales como la manera de distribuir los recursos económicos de manera óptima.

El presupuesto de egresos es el instrumento con el que el Estado mexicano debe garantizar la satisfacción de las necesidades sociales, por lo que, frente a sus resultados alcanzados, los cuales no colman las expectativas de la población, es importante la participación de la sociedad en la toma de decisiones referente a este instrumento, como una herramienta que fortalezca la democracia deliberativa e incida directamente en el desarrollo humano.

\section{BIBLIOGRAFÍA}

Abeles, Martín y KiPER, Esteban, "El G-20 y el rol de la Argentina", Serie Aportes, Argentina, núm. 9, 2010.

Auditoría Superior de la Federación, Análisis del Informe de Avance de Gestión Financiera 2016, agosto de 2016, disponible en: http://wwre.asf.gob. mx/uploads/56_Informes_especiales_de_auditoria/ANALISIS_DEL_INFOR ME_DE_AVANCE_DE_GESTION_FINANCIERA_2016.

Auditoria Superior de la Federación, Informe general Cuenta Pública 2014, disponible en: http://wrereasf.gob.mx/Trans/Informes/IR2014i/Docu mentos/InformeGeneral/ig2014.pdf.

Centro de Estudios de las Finanzas Públicas, Gasto presupuestario del sector público al primer trimestre, 2015, junio de 2015, disponible en: http:// wrerc.cefp.gob.mx/publicaciones/documento/2015/junio/cefp0122015.pdf.

Centro de Política y AdMINISTRACión TRIBUTARIA DE LA OGD et al., Estadísticas tributarias en América Latina y el Caribe 1990-2014, OECD Library, 2016.

Chávez Ramírez, Paulina Irma, Las cartas de intención y las políticas de estabilización y ajuste estructural de México: 1992-1994, México, UNAM, Instituto de Investigaciones Económicas, 1996.

EL UNIVERSAL, "El recorte de 2016 en cinco gráficas", El Universal, disponible en: http://interactivo.eluniversal.com.mx/online/datos/presupuesto15/. 
Este libro forma parte del acervo de la Biblioteca Jurídica Virtual del Instituto de Investigaciones Jurídicas de la UNAM

Grupo Banco Mundial, Doing bussines en México 2016. Midiendo la calidady la eficiencia de la regulación, 6a. ed., Washington, Banco Internacional para la Reconstrucción y el Desarrollo, 2016.

Guerrero Amparán, Juan Pablo, Transparencia presupuestaria en cinco países de América Latina, resultados en 2001, México, Porrúa, 2004.

OchoA ANTich, Nancy, Gobernabilidad versus democracia pluralista, Ecuador, Ediciones Abya-Yala, 2003.

Cámara de Diputados, Presupuestos de egresos de la federación para los ejercicios fiscales 2016 y 2017, disponible en: http://werere.diputados.gob.mx.

Krugman, Paul R., Economía internacional. Teoría y política, 9a. ed., Madrid, Pearson Educación, 2012.

Secretaria de Hacienda y CRédito Público, México y el FMI: la carta de intención, disponible en: http://revistas.bancomext.gob.mx/rce/magazines/ 665/11/RCE10.pdf.

Segretaría de Hacienda y Grédito Público, Programa de Regularización de Adeudos "Ponte al Corriente". Transitorio tercero de la Ley de Ingresos de la Federación para el Ejercicio fiscal de 2013, disponible en: http://wreresat. gob.mx/transparencia/rendicion_cuentas/Documents/Informe_PontealCorriente 2013_271213.pdf.

STIGLiTz E., Joseph, El malestar en la globalización, trad. de Carlos Rodríguez Braun, Madrid, Taurus, 2002.

TRANSPERENCY INTERNATIONAL ESPAÑA, Índice de percepción de la corrupción 2015 (IPC), disponible en: http://transparencia.orges/wp-content/uploads/2016/01/ comparacion_ipc-2007_a_2015.pdf.

Turner Barragán, Ernesto Henry et al., El modelo de desarrollo económico de México y Taiwán, México, Ediciones y Gráficos Eón, 2007.

UnidAd de EVALUación y CONTROL DE LA CÁMARA DE Diputados LXIII Legislatura, Datos básicos del Informe de Resultado de la Fiscalización Superior de la Cuenta Pública 2014, febrero de 2016, disponible en: http:// wrerre3.diputados.gob.mx/camara/001_diputados/008_comisioneslx/001_ordina rias/042_vigilancia_de_la_auditoria_superior_de_la_federacion/012_unidad_de_ evaluacion_y_control. 
Este libro forma parte del acervo de la Biblioteca Jurídica Virtual del Instituto de Investigaciones Jurídicas de la UNAM

\title{
DERECHO GOMPARADO SOBRE PRESUPUESTOS PARTICIPATIVOS: MÉXICO-ESPAÑA
}

\author{
Carolina Aguilar Ramos*
}

SUMARIO: I. Introducción. II Experiencia mexicana. III. Experiencia

Europea. IV. Conclusiones. V. Cuadro comparativo final. VI. Bibliografia.

\section{INTRODUCCIÓN}

Las sucesivas reformas constitucionales suscitadas por las demandas de los gobiernos locales han contribuido a promover escenarios de cambio institucional y democrático. El ente local ha demostrado ser el lazo más próximo entre gobierno y sociedad. Esta cercanía ha permitido el diálogo y el desarrollo de prácticas que posibilitan el involucramiento de los habitantes así como la manifestación de las problemáticas del lugar donde residen.

Un ejemplo de buenas prácticas ciudadanas ha sido la implementación de los presupuestos participativos en países latinoamericanos y europeos. Cabe señalar que esta figura tiene origen en Porto Alegre, Brasil, siendo los pioneros en configurar los elementos jurídicos y técnicos necesarios para ampliar la gama del ejercicio de la democracia en el mundo.

En nuestro país, la figura fue aplicada como modelo piloto en el 2012 en la actual Ciudad de México, cuya reiteración demuestra la posibilidad y el éxito de los modelos participativos vinculados al tema presupuestal en nuestro país. Se puede entender por "presupuesto participativo" aquellos recursos destinados en el Presupuesto de Egresos para que los ciudadanos decidan sobre su aplicación, es decir, los habitantes de determinado lugar están facultados para deliberar sobre las obras y acciones a realizase con ese recurso.

El tema de los presupuestos participativos implica considerar aspectos como el espacio territorial, el nivel de población, los entes involucrados, las le-

\footnotetext{
* Maestra en derecho por la Universidad Autónoma del Estado de Morelos. Contacto: carolinaguilar91@gmail.com
} 
Este libro forma parte del acervo de la Biblioteca Jurídica Virtual del Instituto de Investigaciones Jurídicas de la UNAM

yes en la materia, los resultados obtenidos, así como un análisis desde la perspectiva de los derechos humanos involucrados en estas prácticas ciudadanas.

De manera que en el presente artículo se describirá la operatividad de los presupuestos participativos en México y en España, con la finalidad de esclarecer los elementos institucionales, normativos y temporales que los integran. Dicho lo anterior, se parte de explicar las generalidades territoriales y poblacionales del lugar estudio del caso, posteriormente, se describirá la forma de implementación y distribución de la carga de trabajo, continuando con la legislación aplicable en el proceso y conforme a los derechos humanos, junto con los resultados obtenidos. En la parte final, se incluye un cuadro comparativo con los elementos más distintivos de cada proceso de presupuesto participativo.

\section{EXPERIENCIA MEXICANA}

\section{Ciudad de México}

La Ciudad de México cuenta con una extensión territorial de 1,485 kilómetros cuadrados ${ }^{1}$ y una población total de 8.851 millones de habitantes. ${ }^{2}$ Se encuentra dividida en 16 delegaciones bajo el esquema de ser un Distrito Federal, el cual sufrirá algunas modificaciones con motivo del cambio de denominación reciente. Ocupa el octavo sitio de las ciudades con un producto interno bruto más alto en el mundo. Por cuanto a su dependencia financiera, a partir del 2013 la Ciudad de México figura entre las entidades que necesitaron en mayor medida de los recursos destinados por la federación, específicamente del ramo 28.

Es en 2010 cuando el Instituto Federal Electoral (IFE), actualmente Instituto Nacional Electoral (INE), debido a la reforma político electoral de febrero de 2014, publica la Ley de Participación Ciudadana en la actual Ciudad de México, lo que originó cuatro consultas ciudadanas en materia de presupuesto participativo por medio de los comités y consejos ciudadanos, los cuales por primera vez tuvieron a bien definir los proyectos específicos sobre los que serían utilizados los recursos del presupuesto.

La técnica implementada en la ahora Ciudad de México ha sido a través de dicho mecanismos de participación ciudadana en el tema presupues-

\footnotetext{
1 Referencias geográficas proporcionadas por la Dirección de Capacitación del Instituto Nacional de Estadística y Geografía.

2 Proyecciones de la Secretaría General del Consejo Nacional de Población en relación al total de población correspondiente al periodo 2010-2050.
} 
Este libro forma parte del acervo de la Biblioteca Jurídica Virtual del Instituto de Investigaciones Jurídicas de la UNAM

tal. Esta técnica de elaboración del presupuesto confiere a los ciudadanos la facultad de decidir sobre la aplicación de los recursos en sus respectivas colonias y delegaciones.

Como se ha referido anteriormente, el respaldo jurídico de dicha práctica se encuentra en la Ley de Participación del Distrito Federal, y los organismos que funcionan como enlace entre gobierno y ciudadanía son los ya mencionados comités ciudadanos y los consejos de los pueblos.

\section{Distribución de la carga de trabajo}

Dentro de los órganos de participación ciudadana que la ley anteriormente mencionada reconoce con atribuciones se encuentran los comités ciudadanos, el consejo ciudadano, el consejo del pueblo y el representante de manzana. En cuanto a las autoridades en materia de participación ciudadana se encuentra el jefe de gobierno, la Asamblea Legislativa, los jefes delegacionales y al Instituto Electoral, quienes están obligados a garantizar el respeto y vigilancia de los derechos conferidos por esta ley.

Corresponde al Instituto Electoral realizar las capacitaciones a los distintos órganos de representación ciudadana, así como el desarrollo y cómputo de otros mecanismos de participación ciudadana como el plebiscito y el referéndum, así como coordinar los procesos de elección de los comités ciudadanos $y$ de los consejos de los pueblos.

Se subraya que la consulta ciudadana sobre presupuesto participativo no es uniinstancial, sino que consta de dos momentos: en el primero de ellos llevado a cabo durante los meses de junio a agosto de cada año se realizan reuniones en conjunto entre los jefes delegacionales y los comités ciudadanos para definir, en primer lugar, las necesidades de las respectivas colonias. En un segundo momento, durante los meses de enero y febrero correspondientes al año siguiente se procede a la rectificación de la aplicación de esos recursos presupuestados por parte de las autoridades.

Es durante esta segunda etapa de la consulta ciudadana donde se realiza el seguimiento y evaluación por parte de los comités ciudadanos, los consejos de los pueblos y el órgano electoral. Del mismo modo, es este último órgano quien emite las convocatorias por medio de su página de internet para hacer del conocimiento sobre la forma en que se desarrollarán las consultas ciudadanas en tema de presupuesto participativo. Los asuntos que se tratan contemplan obras y servicios, infraestructura urbana y atención a la seguridad ciudadana o prevención de delitos. 
Este libro forma parte del acervo de la Biblioteca Jurídica Virtual del Instituto de Investigaciones Jurídicas de la UNAM

En cuanto a la presentación de proyectos por parte de los ciudadanos, estas requieren sujetarse a los lineamientos y formatos establecidos por el órgano electoral, dentro de los cuales se encuentran: un nombre, el rubro al que pertenece el proyecto, los costos aproximados sujetos al Tabulador de Precios Unitarios del Gobierno del Distrito Federal, la ubicación que se propone, así como la explicación del por qué se solicita dicho proyecto y el número de personas que resultarían beneficiadas en caso de que éste se aprobara.

Atendiendo al aspecto municipal, se han creado diversos organismos auxiliares para los Ayuntamientos, como los siguientes:

a) Comités de manzana, los cuales se integran por un jefe de manzana, un secretario y tres vocales.

b) Asociación de colonos, constituida por los jefes de los comités de manzana de cada colonia, pueblo o localidad de municipio, a cargo de su correspondiente directiva.

c) Junta de vecinos de cada barrio, pueblo o localidad del municipio.

d) Consejo de colaboración, formado por los presidentes de las juntas de vecinos de cada colonia, pueblo o localidad del municipio. ${ }^{3}$

El modo de implementación es generalizado para toda la ciudad una vez que por parte de la Asamblea Legislativa queda aprobado el presupuesto como parte de sus atribuciones constitucionales. Posteriormente se le asigna presupuesto a cada una de las delegaciones ${ }^{4}$ del total presupuestado.

Las evaluaciones a lo ejercitado a través de los presupuestos participativos por cada delegación son realizadas por parte del Instituto Electoral anualmente. Es durante el mes de octubre cuando se exhiben los resultados ante la Comisión de Participación Ciudadana, donde continua vigente la presencia de los ciudadanos, así como la concurrencia de algunas organizaciones ciudadanas. ${ }^{5}$

La facultad de realizar la supervisión se le delega a la Comisión de Vigilancia, integrada por cinco ciudadanos que son seleccionados con base en su sentido de honorabilidad y vocación de servicio en las acciones comunitarias durando en el cargo hasta por tres años. La función de la Comisión

3 Valencia Carmona, Salvador, Derecho municipal, México, Porrúa, 2003, p. 34.

4 Dicha asignación no deberá ser menor del 1\% ni mayor del 3\% del total del recurso contemplado en el presupuesto de ese ejercicio fiscal.

5 La Dirección Ejecutiva de Participación Ciudadana en el Distrito Federal (ahora Ciudad de México), recibió hasta noviembre de 2014, un total de 188.764 opiniones. 
Este libro forma parte del acervo de la Biblioteca Jurídica Virtual del Instituto de Investigaciones Jurídicas de la UNAM

consiste en dar seguimiento a las actividades de los comités ciudadanos y emitir un informe anual sobre su funcionamiento.

\section{Legislación aplicable}

En este tipo de prácticas es posible referirse como mecanismos de participación ciudadana directa, debido a que permiten no únicamente el seguimiento al gasto público, sino que se contempla el involucramiento de los ciudadanos desde el momento de la planificación presupuestal.

El proceso de seguimiento al gasto y rendición de cuentas en el Distrito Federal está sujeto al artículo 54 de la Ley de participación ciudadana que establece lo siguiente:

Los habitantes de la ciudad tienen el derecho de recibir los informes generales y específicos acerca de la gestión y, a partir de ellos, evaluar la actuación de sus servidores públicos. Asimismo, las autoridades locales del gobierno rendirán informes por lo menos una vez al año y al final de su gestión para efectos de evaluación sobre su desempeño por parte de los habitantes del Distrito Federal.

Es así como dentro del proceso presupuestario la Asamblea Legislativa, en ejercicio de sus atribuciones, comenzó a prever las decisiones tomadas sobre la aplicación de los recursos correspondientes a los presupuestos participativos para incluirlos en el presupuesto de las delegaciones.

Asimismo, en el artículo 83 de la citada ley se conceptualiza al presupuesto participativo como aquel sobre el cual los ciudadanos deciden respecto a la forma en que se aplican recursos en proyectos específicos en las colonias y pueblos originarios en que se divide el territorio del Distrito Federal (ahora Ciudad de México) contemplando además los recursos del presupuesto participativo respecto a un 3\% del presupuesto anual de las delegaciones.

El mecanismo que sustenta a este tipo de presupuestos en el Distrito Federal, es la consulta ciudadana, cuyo fundamento jurídico se encuentra en el artículo 35 constitucional y en el artículo 84 de la Ley de Participación Ciudadana, facultando al Instituto Electoral a realizar la convocatoria para la consulta sobre presupuesto participativo durante el segundo domingo de noviembre de cada año, cuyo objeto es el definir los proyectos específicos en que se aplicarán los recursos correspondiente al ejercicio fiscal inmediato. 
Este libro forma parte del acervo de la Biblioteca Jurídica Virtual del Instituto de Investigaciones Jurídicas de la UNAM

\section{Resultados}

Para ejemplificar los resultados obtenidos a través de las consultas públicas sobre presupuestos participativos en la Ciudad de México, en el siguiente cuadro se muestran algunos de los proyectos más comunes:

\section{PROYECTO CON MAYOR NÚMERO DE VOTOS EN LA CONSULTA}

\section{CIUDADANA SOBRE PRESUPUESTO PARTICIPATIVO 2016}
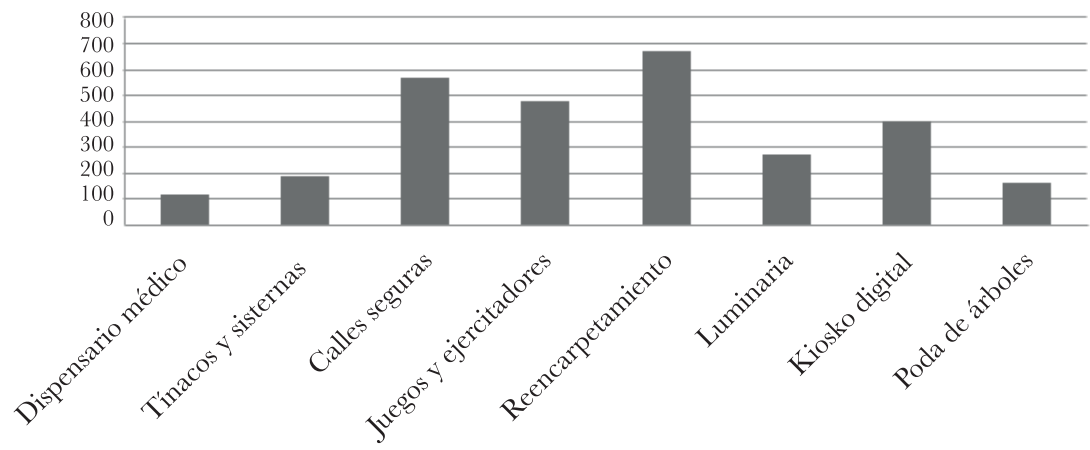

FUENTE: Gráfico propio realizado con los resultados de la consulta pública sobre presupuestos participativos en la Ciudad de México, 2016, disponible en: https://sistemas.iedf.org.mx/consulta_fp/consulta2016/resultados/index.php.

En el caso particular de la Ciudad de México, la gran mayoría de los diputados de todos los partidos políticos representados en la Asamblea Legislativa, aprobaron un monto total de 181 mil 334 millones de pesos como presupuesto a ejercer en 2016. Anualmente las delegaciones usan el $3 \%$ de su presupuesto para realizar proyectos propuestos y elegidos por los habitantes de cada colonia.

Así pues, la institucionalización de normas claras y el reconocimiento real de los derechos de los ciudadanos por parte de los diferentes actores, permitiría consolidar las condiciones necesarias que permitan la participación y el uso efectivo de los recursos públicos, derechos considerados fundamentales, en virtud de su estrecha relación con el desarrollo de la persona ${ }^{6}$ y como para la dignidad en general.

6 Huerta, Carla, "La protección y el desarrollo jurisdiccional de los derechos fundamentales en México tras las reformas de 2011 ", fusticia constitucional, derechos humanos y democracia en América Latina, Colombia, Universidad de Externado de Colombia, 2014, p. 437. 
Este libro forma parte del acervo de la Biblioteca Jurídica Virtual del Instituto de Investigaciones Jurídicas de la UNAM

\section{EXPERIENCIA EUROPEA}

\section{Comunidad Autónoma de Madrid}

Cabría recordar que la Comunidad Autónoma de Madrid nace a partir de la creación de la Constitución de 1978. De este hecho histórico se desprenden los principios generales de la organización territorial, los cuales se encuentran validados en este ordenamiento, al señalarse que la organización territorial del Estado será en municipios, en provincias y en las Comunidades Autónomas que se constituyan, las cuales gozan de plena autonomía para la gestión de sus respectivos intereses. ${ }^{7}$

Madrid cuenta con una extensión territorial de 8,030 kilómetros cuadrados $^{8}$ y con una población total de 6.454 millones de habitantes. ${ }^{9}$ Asimismo, tiene un PIB de 203.626 millones de euros, siendo la comunidad autónoma con mayor crecimiento de todo el territorio Español. Su modelo de financiación sufrió una modificación como consecuencia de la aprobación de la Ley Orgánica 3/2009, por el cual se ampliaron los porcentajes de participación en los recursos tributarios. Cabe señalar que el 75\% del total del Fondo de Garantía de los Servicios Públicos Fundamentales se obtiene de los impuestos especiales sobre el tabaco, hidrocarburos, bebidas alcohólicas, transporte, electricidad, el juego; así como los obtenidos por el IVA, el IRPF $^{10}$ y los actos jurídicos realizados por el ente local.

En lo relativo a la administración y el derecho a participar, el partido político que ejerció el poder en años anteriores aplicaba un modelo de democracia exclusivo a las asociaciones ciudadanas. Empero, con la entrada del nuevo gobierno, la Junta y sus respectivas áreas involucradas al tema participativo configuraron un nuevo paradigma institucional con características de ser más incluyente e individual. Esto se realizó mediante la creación de una plataforma electrónica conocida como: decidemadrid. es. Con este cambio, se modifica el ejercicio de la democracia directa con resultados vinculantes al orden gubernamental, a través de los conocidos

\footnotetext{
7 Ibidem, artículo 137.

8 Extensión superficial de las comunidades autónomas, obtenida del sitio oficial del Instituto Nacional Electoral de España.

9 Padrón de población por comunidades autónomas, provincias, capitales y municipios, presentado por el Instituto de Estadística de la comunidad de Madrid.

10 Información obtenida del sitio de Relaciones con Inversores de la Comunidad Autónoma de Madrid, en lo relativo al modelo de financiación y a los ingresos de la comunidad para el 2016, la información completa disponible en: http://wrere.madrid.org/cs/Satellite?pagen ame $=$ Inversor $\% 2$ FPage $\% 2$ FINVE_contenidoFinalElanguage $=$ es $\mathcal{E}^{2}$ cid $=1158849749452$.
} 
Este libro forma parte del acervo de la Biblioteca Jurídica Virtual del Instituto de Investigaciones Jurídicas de la UNAM

presupuestos ciudadanos, recursos que no se encuentran etiquetados bajo ningún rubro en los ejercicios fiscales más que los que señalen la mayoría de los ciudadanos.

La práctica de estos presupuestos ciudadanos en Madrid, se lleva a cabo a través de distintas fases. En la primera de ellas, se hace convocatoria pública por todos los medios de comunicación posibles: desde canales de televisión, canales de televisión cuya emisión es exclusiva del sistema metro Madrid, mediante las redes sociales, por plataformas en los edificios y plazas alrededor de la ciudad, por medios radiofónicos, etcétera.

Consecuentemente, se apertura el espacio en la plataforma electrónica o en forma presencial, para que los ciudadanos que tengan interés en presentar una propuesta de inversión la exterioricen. Para estos efectos, se entiende por inversión todo aquello que el Ayuntamiento puede construir o adquirir y que su duración prevista es superior a un año, ${ }^{11}$ y los rubros en que se puede dirigir una inversión son los siguientes: creación, reposición, reforma de infraestructuras o adquisición, reposición de transporte y aplicaciones informáticas. ${ }^{12}$

Un aspecto que se debe de tomar en consideración, es lo relativo a los lineamientos que se establecieron por parte del ente administrativo para señalar las características de lo que se considera una propuesta viable: no debe ser fungible, su duración debe ser superior a doce meses, deben ser susceptibles a ser parte del patrimonio de la Comunidad Autónoma, su motivación debe ser legal y no atentar contra el bien común, debe ser una propuesta de inversión ${ }^{13}$ y debe sujetarse a alguno de los siguientes fines: movilidad, transporte, urbanismo, vivienda, medio ambiente, empleo, salud, educación, consumo, deportes, promoción e innovación económica.

En la segunda fase, los mayores de 16 años pueden realizar la votación de las propuestas de la siguiente forma: se publica el presupuesto total disponible, las propuestas con su coste estimado, y se seleccionarán tantas propuestas sean posibles hasta agotar el presupuesto. ${ }^{14}$ De manera directa, el

11 Todas las propuestas de inversión correspondientes al 2016, se pueden consultar en la plataforma de decidemadrid.es, disponible en: https://decide.madrid.es/participatory_budget_ info\#21.

12 Conviene mencionar que todo aquello que se encuentre fuera de estos términos será eliminado del proceso de aceptación y viabilidad de las propuestas planteadas, toda vez que dichas acciones involucren órganos que superen la esfera local o el costo del presupuesto destinado a estos fines, o bien, sea contraria a la ley.

13 La característica de inversión se presenta debido a la forma en que el presupuesto de Madrid se clasifica.

14 En la dinámica actual se ha comprobado que no es forzoso el agotamiento del total del presupuesto participativo, ya que cada ciudadano cuenta con la opción de votar por más de 
Este libro forma parte del acervo de la Biblioteca Jurídica Virtual del Instituto de Investigaciones Jurídicas de la UNAM

ciudadano está facultado para presentar modificaciones o demandas requeridas para la comunidad o el Distrito que desee. No es requisito comprobar el domicilio, ya que puede votar indistintamente de donde reside.

Los requisitos para crear una propuesta de inversión o votar sobre las ya existentes en la plataforma electrónica son: encontrarse empadronado en Madrid, ser mayor de 16 años, realizar la verificación de la cuenta de usuario mediante un correo electrónico o bien, a través de las Oficinas de Atención Ciudadana en caso de realizar la participación de forma presencial.

La forma de llevar a cabo las propuestas es mediante la plataforma electrónica de decidemadrid.es, o bien, en caso de no contar con computador o con conexión a Internet, el ciudadano puede asistir de manera personal a las distintas centrales acondicionadas para eso, las cuales se habilitan en zonas públicas mayormente concurridas de toda la ciudad.

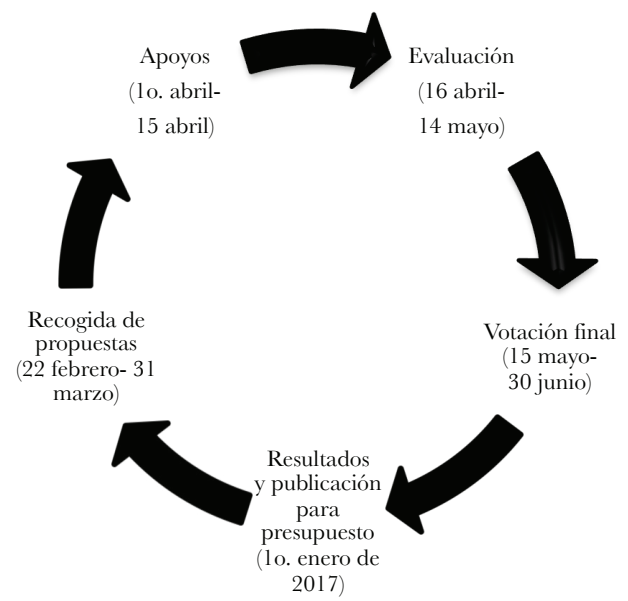

Las decisiones tomadas se incorporarán a los presupuestos públicos, ejerciendo la corresponsabilidad fiscal ciudadana,${ }^{15}$ unido a la técnica y la política, se procede a ejecutar las acciones que hayan resultado mayormente seleccionadas y, con base en la capacidad presupuestal y el tiempo que apremie cada una de dichas obras, se realizarán.

Se clasificó la ejecución en: acciones de corto plazo, como aquellas realizables y para concluir en el mismo año del ejercicio fiscal de dicho presupuesto participativo; y las acciones a largo plazo, las cuales por su natu-

una propuesta. En otras palabras, se puede votar desde una propuesta hasta las que alcance el recurso.

15 Molina Molina, José, Ciudadano y gasto público, por una gobernanza transparente y participativa, 3a. ed., Pamplona, Thomson Reuters Aranzadi, 2014, p. 142. 
Este libro forma parte del acervo de la Biblioteca Jurídica Virtual del Instituto de Investigaciones Jurídicas de la UNAM

raleza no serán concluidas en ese ejercicio fiscal, pero cuyo financiamiento si corresponde a dicho plazo anual, por lo que no alteraría la capacidad presupuestal de años posteriores. ${ }^{16}$

Una vez que se recogen los resultados de los habitantes en Madrid, se procedió a emitir un pliego de carácter internacional, donde se convocaba a expertos en ingeniería de todo el mundo a que participaran en la ejecución de la obra.

Los presupuestos ciudadanos cuentan con la particularidad de que la población se involucra de manera directa y sin intermediarios, entendiendo que el nuevo esquema participativo maneja el sentido de una participación individual que no toma como requisito previo el que sea bajo un contexto de organización o de grupo con determinado número de personas inscritas, del mismo modo no se requiere la intervención de un partido político, ya que perdería la esencia de ser exclusivamente ciudadano.

\section{Distribución de la carga de trabajo}

Con un total de 60 millones de euros ${ }^{17}$ la Dirección General de Participación Ciudadana, del Área de Participación Ciudadana, Transparencia y Gobierno Abierto, realiza un estudio en concreto de los resultados obtenidos por la participación de los ciudadanos en la ciudad, para evaluar los costos que dichas acciones implican, hacer públicos sus resultados de manera inmediata y presentar, de igual forma, a finales del mes de julio, los análisis correspondientes, los cuales se sujetan a opiniones de expertos en el tema, así como del resto de las áreas de gobierno que se vean inmersas en el tema.

Un elemento que resulta fundamental en el proceso de éstos presupuestos es la participación de las asambleas ciudadanas. Dichas asambleas consisten en un mecanismo de coordinación y comunicación fijo entre el gobierno y la ciudadanía de los distintos distritos de la comunidad. Fungen como una estructura de representación local, a través de las cuales se pueden realizar consultas y negociaciones de forma más ordenada y, sobre todo, dotan de legitimidad los compromisos alcanzados en dichas reuniones con el fin de que en un futuro se asuman por un número significativo de autoridades locales. ${ }^{18}$

16 Obtenido de la entrevista realizada al director general de Participación Ciudadana, D. Gregorio Planchuelo Sainz, en las oficinas del Área de Participación Ciudadana, Transparencia y Gobierno Abierto, Madrid, 19 de mayo de 2016.

17 La distribución del recurso se realiza de la siguiente manera: 24,000,000 euros para las propuestas de toda la ciudad y 36,000,000 euros para las propuestas de los distritos.

18 Parrado, Salvador, Gobiernos y administraciones públicas en perspectiva comparada, Valencia, Tirant lo Blanch, 2013, p. 225. 
Este libro forma parte del acervo de la Biblioteca Jurídica Virtual del Instituto de Investigaciones Jurídicas de la UNAM

En concreto, el caso práctico de la Alameda de Osuna en el distrito de Barajas, cuenta con una asociación de ciudadanos con un total, hasta 2016, de 1100 socios, los cuales están plenamente facultados por las directrices señaladas en las normas de participación ciudadana que se encuentran establecidas en la agenda del mismo Ayuntamiento así como de la Junta Municipal de Distrito.

La Junta Municipal del Distrito en cada distrito, se reúne una vez por mes de manera cotidiana, existiendo la posibilidad de que se reúnan de manera extraordinaria cuando se deba subsanar algún planteamiento con carácter de urgente. ${ }^{19}$ Dicha junta mensual se realiza, en primer término, con la publicación de una convocatoria expedida por la Concejalía Presidencia del Distrito mediante un decreto, señalando la fecha, la hora y el lugar para desarrollarse.

El pleno de la Junta Municipal se integra por el gerente, el concejal presidente, el secretario y los vocales vecinos. Algunas de las facultades de estas asociaciones vecinales son: la colaboración en los presupuestos generales del Ayuntamiento, la presentación de las propuestas y demandas ciudadanas.

Las necesidades que de manera frecuente se han presentado como urgentes ante el concejal presidente, han consistido en la prestación de servicios básicos y algunas funciones de infraestructura para la ciudad, como ejemplo se pueden señalar los siguientes: asuntos relacionados con la sanidad, la necesidad de un autobús con dirección al hospital más próximo a la zona, la apertura de un centro de especialidades médicas, el acceso del barrio de Alameda de Osuna hacia el aeropuerto, la terminación de uno de sus colegios, entre otros.

Desde los años ochenta se estableció la existencia de vocales vecinos que son personas elegidas por los partidos políticos, en número proporcional a su representación en el Ayuntamiento y que constituyen a la Junta Municipal. Por cada distrito hay 25 vocales vecinos. La función principal de estos vocales consiste en hacer eco de las demandas y necesidades de los habitantes del distrito y trasladarlas a los plenos de las juntas, de la misma forma que tienen voto en las propuestas que se presenten. ${ }^{20}$

Para 2015, se crearon las comisiones participativas, dando lugar a ocho. La característica de estas comisiones es que son abiertas al público en gene-

19 Obtenido por la entrevista realizada al Portavoz de la Asociación de Vecinos de Alameda de Osuna, Francisco del Pozo Estévez, el 12 de mayo de 2016, en las Oficinas de la Organización comunitaria, Madrid, España.

20 Obtenido mediante la entrevista realizada al Concejal de Participación Ciudadana, Pablo Soto Bravo, durante la celebración de las Conferencias Internacionales de Ciudades democráticas, en las instalaciones del Museo Reina Sofia, Madrid, España, el 27 de mayo de 2016. 
Este libro forma parte del acervo de la Biblioteca Jurídica Virtual del Instituto de Investigaciones Jurídicas de la UNAM

ral. Mediante sus reuniones se concretaron propuestas de los participantes y otras que se hicieron llegar por medio de urnas o de correos electrónicos que se habilitaron para ese fin. Las comisiones ciudadanas que se han generado, hasta la fecha, son: cultura y juventud, desarrollo urbano sostenible, medio ambiente y movilidad, salud, equidad y derechos sociales, educación, empleo y comercio, participación y transparencia y deporte.

\section{Legislación aplicable}

Se entiende como el contenido primario para el establecimiento de lo que se denomina como Estado social y democrático al artículo 1.1 de la Constitución Española. No obstante, el derecho a la participación ciudadana se localiza en distintos numerales de este documento, como es el caso de la participación en la vida política (artículo 23.1), en la enseñanza (artículo 27.5), en la juventud (artículo 48), en la elaboración de disposiciones administrativas (artículo 105) en la justicia (artículo 125), en la seguridad social (artículo 129.1) o en la empresa (artículo 129.2).

De manera más específica, la legislación que atañe al tema de los presupuestos participativos, parte del numeral 51 de la Constitución Española, al señalarse en su contenido los principios rectores de la política social y económica, así como la obligación de los poderes públicos en defensa de los intereses legítimos de los usuarios.

Del mismo modo, es por medio del Reglamento Orgánico de Participación Ciudadana del Ayuntamiento de Madrid, que deroga a las Normas de Participación Ciudadana de 27 de mayo de 1992. De igual manera, la Ley 7/1985 de 2 de abril, Reguladora de las Bases del Régimen Local y el Acuerdo por el que se determina la cuantía que se destinará en el proyecto del Presupuesto General del Ayuntamiento de Madrid para los presupuestos participativos, donde se establece la fórmula de distribución del mismo.

\section{Resultados}

Los resultados que arrojó el proceso de votación de los presupuestos ciudadanos en Madrid han demostrado que de un total de 6,464,078 habitantes ${ }^{21}$ el número de propuestas enviadas fue de 5,184, en donde las clases

21 Censo poblacional de 2015, siendo la Comunidad Autónoma de España la tercera posición en cuanto a total de población se refiere. 
Este libro forma parte del acervo de la Biblioteca Jurídica Virtual del Instituto de Investigaciones Jurídicas de la UNAM

medias son las más activas. ${ }^{22}$ Respecto de los diversos tipos de servicios públicos y el grado de satisfacción ciudadana de los habitantes españoles, afirmaron estar muy satisfechos con el sistema de transporte público, seguido de los servicios de sanidad, obras públicas y educación. ${ }^{23}$

En lo respectivo a los servicios de sanidad de la Comunidad Autónoma de Madrid, se demostró que el grado de satisfacción sobre los servicios de limpieza de las calles es satisfactorio, seguido de la recogida de basura selectiva de residuos como satisfecho, ${ }^{24}$ en relación a centros deportivos y culturales, las bibliotecas y las instalaciones deportivas públicas son los que cuentan con un número adecuado de instalaciones en relación a su población. Sobre infraestructura de jardines, parques y pasos para los ciclistas, éstos últimos son considerados como excesivos ya que sobran espacios para estas funciones. Por último, la calidad del agua es positiva en relación al porcentaje de ciudadanos satisfechos del resto de las comunidades autónomas.

En otro orden de ideas, sobre las modalidades de participación, el canal presencial sigue siendo el principal medio a través del cual los ciudadanos contactan con la administración pública. Cerca del 80\% de la población afirma haber acudido en los últimos doce meses a alguna oficina para algún trámite. ${ }^{25}$ Por otra parte, quedó claro que elementos como el trato, la profesionalidad o las posibilidades que la administración pública pone al alcance de ciudadano para que pueda participar adquieren especial relevancia. ${ }^{26}$

Bajo este contexto, las innovaciones en materia de elaboración y gestión presupuestaria en la esfera local, como es el caso de los presupuestos participativos, no tienden a reemplazar el presupuesto tradicional, pero si a perfeccionarlo, como un mecanismo para evolucionar de una gestión que se centraba en aspectos procedimentales y operativos, a una gestión y acción pública estratégica. ${ }^{27}$

22 Pineda Nevot, Carmen, "Presupuesto local y participación ciudadana en el ámbito europeo”, Revista GAPP, Madrid, núm. 28, septiembre de 2003, p. 130.

23 Ministerio de Política Territorial y Administración Pública y la Agencia de Evaluación y Calidad, "Agenda pública y satisfacción con los servicios públicos en el Estado Autonómico", Observatorio de Calidad de los Servicios Públicos, España, 2010, p. 39.

24 Ibidem, 162.

25 Ministerio de Hacienda y Administraciones Públicas y la Agencia de Evaluación y Calidad, Estabilidad y mejoría en los servicios públicos, España, 2016, p. 119.

26 Agencia Estatal de Evaluación de las Políticas Públicas y la Calidad de los servicios, La calidad de los servicios públicos y las actitudes de los ciudadanos hacia las medidas modernizadoras de la administración pública, España, 2013, p. 40.

27 Iglesias Ángel, "El presupuesto como instrumento de gobernanza e innovación en la gestión pública local”, Revista Tributos Locales, España, núm.71, julio de 2007, p. 82. 
Este libro forma parte del acervo de la Biblioteca Jurídica Virtual del Instituto de Investigaciones Jurídicas de la UNAM

De este modo, la práctica ha demostrado que la implementación de canales de participación fomenta la igualdad entre los ciudadanos, así como les permite mejorar su calidad de vida y satisfacer sus necesidades básicas. Desde la perspectiva presupuestal, la realización dichos medios ha permitido maximizar el uso de los recursos disponibles, focalizar la toma de decisiones, determinar los objetivos transversales, así como contar con mecanismos de exigibilidad que tengan, inclusive, alcances de investigación, sanción y reparación ${ }^{28}$ en el uso indebido de los recursos públicos.

\section{CONCLUSIONES}

La comparación realizada en el presente artículo sobre la forma de implementación de los presupuestos participativos en ambos países permite puntualizar los elementos distintivos entre un mecanismo y el otro, con el objetivo de ubicar las diferencias y similitudes de esta práctica ciudadana.

Primeramente, en relación con el monto asignado a ejercerse por medio del presupuesto ciudadano aprobado por la Asamblea Legislativa de la Ciudad de México, cada delegación destina un porcentaje que oscila de un mínimo $1 \%$ y un máximo 3\%; a diferencia de lo contemplado para la Comunidad Autónoma de Madrid, donde se destina un total de 60,000,000 euros, siendo 36 millones de éstos $(60 \%)$ para la totalidad de sus distritos y 24 millones $(40 \%)$ a toda la comunidad.

Una diferencia más es en lo relativo a las autoridades e instituciones involucradas en el proceso, donde corresponde al Jefe de Gobierno de la Ciudad de México, junto con sus jefes delegacionales, en coordinación con el consejo del pueblo, los comités ciudadanos y sus asambleas, la tarea de coordinar el ejercicio participativo; en España compete al encargado del área de participación ciudadana y gobierno abierto del Ayuntamiento de Madrid, tanto como a la Junta de Gobierno y a sus respectivas Juntas de Distrito.

Tratándose de las similitudes se puede apreciar que el ejercicio participativo ha requerido de la habilitación de órganos auxiliares que faciliten el proceso ciudadano. De tal suerte que, en la Ciudad de México se cuenta con la Comisión de vigilancia y las oficinas del Instituto Electoral de la Ciudad de México, así como con el área técnica de las delegaciones, la cual proporciona información y apoyo técnico para la elaboración de los proyectos a los ciudadanos interesados en presentar alguno.

28 Conferencia del D. Daniel Velázquez, en el Seminario de Derechos Humanos y Presupuesto, realizado en las instalaciones del Posgrado de Economía de la Universidad Nacional Autónoma de México, Ciudad Universitaria del 22 al 23 de septiembre de 2016. 
Este libro forma parte del acervo de la Biblioteca Jurídica Virtual del Instituto de Investigaciones Jurídicas de la UNAM

En el caso español existen 26 oficinas de atención a la ciudadanía de existencia permanente y en cada uno de los distritos de la Comunidad Autónoma. De tal suerte de que en el caso de que la participación se realize de forma personal, estas oficinas cuentan con el equipo necesario para auxiliar y orientar a los habitantes durante el proceso de presupuesto ciudadano. Del mismo modo, posen una secretaría técnica encargada de realizar las aproximaciones de costos de los proyectos seleccionados en la penúltima fase del presupuesto ciudadano.

En relación a la prestación de los servicios públicos, la diferencia radica en que la legislación española, en el caso particular de la Ley Reguladora de las Bases del Régimen Local, faculta a los ciudadanos a exigir la eficacia y continuidad de dichos servicios. Los tipos de proyectos que han sido presentados en ambas latitudes no difieren en gran medida, por lo cual es posible indicar que son los siguientes: movilidad y transporte, urbanismo y vivienda, medio ambiente, obras y servicios, infraestructura, prevención del delito, cultura y deporte y salud.

Finalmente, bajo una visión gubernamental de los procesos participativos, los supuestos que se pueden asumir a través de la elaboración de presupuestos ciudadanos son: el máximo aprovechamiento del conocimiento de la comunidad aprendiendo experiencias que permitan en determinado momento la apertura del desarrollo, crear conciencia pública sobre los beneficios que estas prácticas han obtenido en experiencias latinoamericanas y europeas, así como el mantenimiento de una comunidad informada, logrando así contar con un recurso a través del cual pueda manifestar su aprobación o rechazo.

\section{GUADRO COMPARATIVO FINAL}

\begin{tabular}{|c|c|c|}
\hline Característica & $\begin{array}{c}\text { Comunidad Autónoma } \\
\text { de Madrid }\end{array}$ & Ciudad de México \\
\hline $\begin{array}{l}\text { Plazos y etapas del desarro- } \\
\text { llo de los presupuestos parti- } \\
\text { cipativos. }\end{array}$ & $\begin{array}{l}\text { 1. } 22 \text { de febrero al } 31 \text { de mar- } \\
\text { zo: recogida de propues- } \\
\text { tas. } \\
\text { 2. } 1 \text { al } 15 \text { abril: apoyos y eva- } \\
\text { luación. Selección de las } \\
\text { que van a votación final. } \\
\text { 3. } 15 \text { de mayo al } 30 \text { de junio: } \\
\text { votación final y selección } \\
\text { de las finales a incluirse } \\
\text { en el proyecto inicial del } \\
\text { Presupuesto General del } \\
\text { Ayuntamiento de Madrid. }\end{array}$ & $\begin{array}{l}\text { 1. Junio a agosto: para defi- } \\
\text { nición de acciones priori- } \\
\text { tarias. } \\
\text { 2. Enero y febrero: decisión } \\
\text { sobre la realización del } \\
\text { gasto aprobado (artículo } \\
51 \text { de la Ley de Participa- } \\
\text { ción Ciudadana). }\end{array}$ \\
\hline
\end{tabular}


Este libro forma parte del acervo de la Biblioteca Jurídica Virtual del Instituto de Investigaciones Jurídicas de la UNAM

\begin{tabular}{|c|c|c|}
\hline Característica & $\begin{array}{c}\text { Comunidad Autónoma } \\
\text { de Madrid }\end{array}$ & Ciudad de México \\
\hline $\begin{array}{l}\text { Medios y canales de partici- } \\
\text { pación ciudadana. }\end{array}$ & $\begin{array}{l}\text { Espacios presenciales de de- } \\
\text { bate, convocatorias públicas } \\
\text { por medios de comunicación } \\
\text { masiva y mediante la plata- } \\
\text { forma de decide.madrid.es. }\end{array}$ & $\begin{array}{l}\text { Por medio de la página de } \\
\text { wrerw.iedf.org.mx y los medios } \\
\text { de comunicación masiva. }\end{array}$ \\
\hline Porcentaje de participación. & 45,522 participantes. & 188,764 participantes. \\
\hline Requisitos para participar. & $\begin{array}{l}\text { 1. Estar empadronado en } \\
\text { Madrid. } \\
\text { 2. Ser mayor de } 16 \text { años. } \\
\text { 3. Votación presencial: a } \\
\text { través de las } 26 \text { oficinas } \\
\text { de atención a la ciudada- } \\
\text { nía, presentando el DNI. } \\
\text { 4. Votación en línea: previa } \\
\text { verificación de cuenta en } \\
\text { la página oficial de decide. } \\
\text { madrid.es. }\end{array}$ & $\begin{array}{l}\text { 1. Acreditar ser ciudadano } \\
\text { mexicano (credencial de } \\
\text { elector). } \\
\text { 2. Formato de proyecto, des- } \\
\text { cargable de la página ofi- } \\
\text { cial del Instituto Electoral } \\
\text { de la ciudad de México, o } \\
\text { bien, } \\
\text { 3. A través de las mesas re- } \\
\text { ceptora de opinión de las } \\
\text { delegaciones. }\end{array}$ \\
\hline Fundamento jurídico. & $\begin{array}{l}\text { Reglamento Orgánico de } \\
\text { Participación Ciudadana } \\
\text { del Ayuntamiento. }\end{array}$ & $\begin{array}{l}\text { Ley de Participación Ciuda- } \\
\text { dana del Distrito Federal. }\end{array}$ \\
\hline $\begin{array}{l}\text { Medios de evaluación del } \\
\text { procedimiento. }\end{array}$ & $\begin{array}{l}\text { Corresponde al área de go- } \\
\text { bierno de participación ciu- } \\
\text { dadana y gobierno abierto } \\
\text { la coordinación de todo el } \\
\text { proceso. }\end{array}$ & $\begin{array}{l}\text { Corresponde al Instituto } \\
\text { Electoral de la Ciudad de } \\
\text { México en conjunto con los } \\
\text { comités ciudadanos y los } \\
\text { consejos de los pueblos la } \\
\text { validación de los resultados. }\end{array}$ \\
\hline
\end{tabular}

\section{BIBLIOGRAFÍA}

Instituto Electoral Giudad de México, Consulta Ciudadana sobre Presupuesto Participativo 2015, Ciudad de México, disponible en: wrwr.iedf.org.mx. Ministerio de HaGienda y Administraciones Públicas Y LA AgenGIA DE EVALUACIÓN Y CALIDAD, Estabilidad y mejoría en los servicios públicos, España, 2016.

Ministerio de Política Territorial y ADMinistración Pública y LA AgEncia de EVAlUACiÓn y CALIDAD, Agenda pública y satisfacción con los servicios públicos en el Estado autonómico, España, Observatorio de la Calidad de los Servicios Públicos, 2010.

Molina MolinA, José, Ciudadano y gasto público, por una gobernanza transparente y participativa, 3a. ed., Pamplona, Thomson Reuters Aranzadi, 2014. 
Este libro forma parte del acervo de la Biblioteca Jurídica Virtual del Instituto de Investigaciones Jurídicas de la UNAM

PARRADO, Salvador, Gobiernos y administraciones públicas en perspectiva comparada, Valencia, Tirant lo Blanch, 2013.

Pineda Nevot, Carmen, "Presupuesto local y participación ciudadana en el ámbito europeo", Revista GAPP, España, núm. 28, septiembre 2003.

Valencia Carmona, Salvador, Derecho municipal, México, Porrúa, 2003. 
Derechos humanos y presupuestos públicos, editado por el Instituto de Investigaciones Jurídicas de la UNAM, se terminó de imprimir el 22 de agosto de 2018 en

. Se

utilizó tipo Baskerville de 9, 10 y 11 puntos. En esta edición se empleó papel cultural 70 x 95 de $50 \mathrm{~kg}$. para los interiores y cartulina couché de 250 gramos para los forros. Consta de 100 ejemplares (impresión digital). 